\title{
Discipline en legende : de identiteit van de sociologie in Duitsland en de Verenigde Staten 1870-1930
}

Citation for published version (APA):

de Wilde, R. (1992). Discipline en legende : de identiteit van de sociologie in Duitsland en de Verenigde Staten 1870-1930. [Doctoral Thesis, Maastricht University]. Rijksuniversiteit Limburg. https://doi.org/10.26481/dis.19920618rw

Document status and date:

Published: 01/01/1992

DOI:

10.26481/dis.19920618rw

Document Version:

Publisher's PDF, also known as Version of record

\section{Please check the document version of this publication:}

- A submitted manuscript is the version of the article upon submission and before peer-review. There can be important differences between the submitted version and the official published version of record.

People interested in the research are advised to contact the author for the final version of the publication, or visit the DOI to the publisher's website.

- The final author version and the galley proof are versions of the publication after peer review.

- The final published version features the final layout of the paper including the volume, issue and page numbers.

Link to publication

\footnotetext{
General rights rights.

- You may freely distribute the URL identifying the publication in the public portal. please follow below link for the End User Agreement:

www.umlib.nl/taverne-license

Take down policy

If you believe that this document breaches copyright please contact us at:

repository@maastrichtuniversity.nl

providing details and we will investigate your claim.
}

Copyright and moral rights for the publications made accessible in the public portal are retained by the authors and/or other copyright owners and it is a condition of accessing publications that users recognise and abide by the legal requirements associated with these

- Users may download and print one copy of any publication from the public portal for the purpose of private study or research.

- You may not further distribute the material or use it for any profit-making activity or commercial gain

If the publication is distributed under the terms of Article $25 \mathrm{fa}$ of the Dutch Copyright Act, indicated by the "Taverne" license above, 


\section{DISCIPLINE EN LEGENDE}

De identiteit van de sociologie in

Duitsland en de Verenigde Staten

1870-1930

\section{PROEFSCHRIFT}

ter verkrijging van de graad van doctor aan de Rijksuniversiteit Limburg

te Maastricht, op gezag van de Rector Magnificus, Prof.mr. M.J. Cohen, volgens het besluit van het College van Dekanen, in het openbaar te verdedigen op donderdag, 18 juni 1992 om 16.00 uur.

door

Reinder de Wilde 
Promotores:

Prof,dr. L.W. Nauta (RUG)

Prof.dr.ir. G.H. de Vries

Beoordelingscommissie:

Prof.dr. L. Boon (voorzitter)

Dr. F. Ankersmit (RUG)

Prof.dr. H. Philipsen

Prof.dr. L.M. de Rijk

Prof.dr.mr. C.J.M. Schuyt (UvA)

Dit proefschrift is tot stand gekomen dankzij een subsidie van N.W.O. 
1. De identiteit van disciplines

2. De geschiedenis van disciplines: identiteit en continuitteit van de sociologie

3. De status van disciplines: legitimiteit en autoriteit van de sociologie

II WETENSCHAP ALS MORAAL

Over wat in de Verenigde Staten aan de vestiging van de sociologie voorafging

1. Het relatieve succes van de Amerikaanse sociologie

2. Sociale Wetenschap: een pre-disciplinaire wetenschap van de samenleving

3. Herbert Spencer in Amerika

4. Het effect van disciplinevorming

III TUSSEN CONFESSIE EN PROFESSIE

Over het maken van een sociologische discipline in de Verenigde Staten

1. De genese van een discipline

2. Kwartier maken in Chicago

3. Evolutionisme en de taal der sociale krachten

4. De politiek van sociologische theorievorming

5. Drie sociale praktijken

IV ONPARTLJDIGE OF WAARDEVRIJE WETENSCHAP

Over wat in Duitsland aan de vorming van een

sociologische discipline voorafging

1. Waardevrijheid en de identiteit van de sociologie

2. Duitse aspiraties: sociologie zonder sociologen

3. Twee omschrijvingen van het waardevrijheidsprobleem

4. Schmoller en de vermaatschappelijking van de politiek

5. Weber en het oplevende constitutionele debat

6. Van Staatswetenschappen naar sociale wetenschappen 
V SOCIOLOGIE ALS PEDAGOGIE

Over de vorming en identiteit van een sociologische

discipline in Duitsland

1. Het lot van het waardevrijheidsgebod

2. Het succes van 'slechte' sociologie

3. De culturele taak van de Weimarsociologie

4. Demarcatie van de sociologie: continuïteit en discontinuïteit

VI EEN DISCIPLINE IN BEWEGING

Over de evolutie van een sociologisch vocabulaire

in de Verenigde Staten

1. De dynamica van disciplines

2. Scheuren in het sociologisch gelid

3. Veranderingen in vocabulaire: differentiatie en continuiteit

4. De praktische context van taalmutaties

5. De constructie van een disciplinaire orde

VII TRADITIES, DISCIPLINES EN DE SOCIOLOGIE

1. Een methodologie voor historisch onderzoek naar disciplines

2. Naar een theorie van disciplines

3. Problemen van disciplinevorming: een terugblik

SUMMARY

BIBLIOGRAFIE 


\section{VOORWOORD}

In de $19 \mathrm{e}$ eeuw wordt de studie van de samenleving steeds meer een zaak van specialisten. Een belangrijk aspect van deze verandering is het ontstaan van verschillende disciplines, zoals de geschiedwetenschap en de economie. Anders dan leerboeken in de sociologie vaak suggeren, spreekt het niet vanzelf dat er naast deze vakken ook een discipline is gevormd die 'sociologie' is gaan heten. Sociologie moest zich op het academische toneell een eigen identiteit verwerven. In dit boek wordt onderzocht hoe dat in Duitsland en in de Verenigde Staten in z'n werk ging en hoe in deze beide landen de identiteit van het vak tot ongeveer 1930 veranderde. De keuze voor de Verenigde Staten is gebaseerd op de overweging dat de sociologie hier eerder dan in andere landen een disciplinaire vorm aannam. Duitsland biedt voor de ontwikkeling van de Amerikaanse sociologie een goed contrast omdat de sociologie daar als discipline niet alleen later maar ook langs andere lijnen gestalte kreeg.

Veel blijft in dit boek onbesproken. Zo brengt de beperking tot de twee genoemde landen met zich mee dat bij voorbeeld de ontwikkeling van de sociologie in Frankrijk stiefmoederlijk wordt bedeeld. Alleen in het inleidende hoofdstuk sta ik stil bij het werk van Comte. Bovendien besteed ik betrekkelijk weinig aandacht aan de ontwikkeling van het beroep van socioloog. Als wetenschapsfilosoof heb ik geen "sociologie van de sociologie' willen schrijven, dat kan beter aan sociologen zelf worden overgelaten. Alhoewel ik niet geloof dat er een wezenlijk onderscheid tussen disciplines en professies bestaat, maakt het toch verschil vanuit welk standpunt men een vak tegemoet treedt. Ik stel me een ander soort vragen dan de beroepensocioloog gewoonlijk doet en heb niet de institutionele groei van de professie in kaart gebracht of de oplages van boeken en tijdschriften onderzocht. Daarentegen wordt in deze studie veel werk gemaakt van de taal die sociologen spreken.

Dit boek vertelt een historisch verhaal, mar is geen zuiver historische studie. Ik probeer ook het genre van de disciplinegeschiedenis te vernieuwen en gevestigde denkbeelden over het karakter van academische disciplines te herzien. De manier waarop dit gebeurt is enigszins ongebruikelijk. In het inleidende hoofdstuk breng ik op een terloopse wijze de probleemstelling van de studie naar voren. De daarop volgende hoofdstukken kunnen als zelfstandige gevalstudies gelezen worden, maar bezitten ook steeds een wijdere strekking. Bij stukjes en beetjes introduceer ik er het methodologische en geschiedtheoretische raamwerk van het onderzoek in. Pas in het slothoofdstuk wordt dit kader in z'n geheel expliciet besproken. Deze dosering is een kwestie van stijl. Maar er ligt ook een opvatting over filosofiebeoefening aan ten grondslag. Fillosofen dienen theorieèn over de taal of de aard van het verleden niet alleen op een sys- 
tematische manier te presenteren, maar ze ook te demonstreren aan de hand van gevalstudies. Bij deze tweede opgave past de hier gekozen opzet.

Nog een opmerking over de terminologie. Sociologie wordt in verschillende tijden en in verschillende landen verschillend geclassificeerd. Soms is het een geesteswetenschap, soms een cultuurwetenschap, soms een sociale wetenschap. Om althans op dit vlak enigszins neutraal te blijwen hanteer ik de term 'menswetenschap' voor al die disciplines die doorgaans niet tot de natuurwetenschappen worden gerekend.

Dit boek is als proefschrift verdedigd. Dat het zo ver kon komen, dank ik in hoge mate aan Gerard de Vries, die niet alleen mijn promotor maar ook mijn leermeester was. De invloed die hij op mijn denken heeft uitgeoefend, is op tal van plaatsen aanwijsbaar. En wanneer de moed mij weer eens in schoenen was gezonken, bezat hij de gave mij te doen geloven dat er op dit boek werd gewacht. Lolle Nauta, mijn tweede promotor, heeft zich door de jaren heen een zeer zorgvuldig lezer van mijn stukken getoond. Hij legde de vinger op talrijke slordigheden en hielp me bij het ontlopen van steeds opnieuw opdoemende valkuilen.

Van onschatbare waarde was de hulp van Marleen Vara bij het drukklaar maken van het manuscript. Ook attendeerde zij mij op allerlei onvolkomenheden in betoog en tekst. Karin Bijsterveld, Tannelie Blom, Trudy Dehue, Hans Harbers, Sjaak Koenis, Annemarie Mol, Dick Pels, en Pauline Westerman deden hetzelfde. Dat het schrijven van dit boek geen eenzaam avontuur was, dank ik aan hen en aan Heleen Pott, met wie ik meer dan alleen de smart van het schrijven van een proefschrift mocht delen. Erkentelijk ben ik ook Liesbeth van der Sluijs voor haar waardevolle literatuursuggesties, Anja Servais voor het vele redactionele werk dat ze me uit handen nam, en Joke Spruijt voor het vertalen van de samenvatting. Bertus de Rijk ten slotte dank ik voor zijn "Leselrüchte".

Maastricht, mel 1992. 


\section{INLEIDING}

\section{De identiteit van disciplines}

Wie wetenschap bedrijft, leeft in een verdeelde wereld. Weinig fysici betreden ooit het terrein van de sociologie, biologen spreken zelden de taal van de psychologie en pedagogen houden zich gewoonlijk verre van de geografie. De wereld van de wetenschap kent vele territoria, afgebakend door disciplinaire grenzen.

Wetenschappelijk onderwijs en onderzoek zijn nog niet erg lang gebonden aan disciplinaire indelingen. Fysica wordt weliswaar al in de oudheid beoefend, maar als aparte wetenschappelijke discipline bestaat het vak nog geen tweehonderd jaar. Veel andere disciplines zijn zelfs nauwelijks meer dan een eeuw oud. De economie, de psychologie en de sociologie beginnen pas in de loop van de $19 \mathrm{e}$ eeuw de vorm van zelfstandige vakgebieden aan te nemen.

De disciplinaire opbouw van wetenschap betekende in veel opzichten een breuk met het verleden. Voor 1800 wordt wetenschap wel al in collectief verband verricht, maar het kader daarvoor is nog de academie of de faculteit. Engelse geleerden als Newton, Hooke en Boyle verenigen zich niet naar vakgebied, maar bewegen zich als leden van de Royal Society op verschillende terreinen. Boyles rival Hobbes schrijft over de principes van de mechanica, maar ook over de grondslagen van de staat. Duitse geleerden werken tot in het begin van de $19 \mathrm{e}$ eeuw binnen een universitair systeem dat slechts vier faculteiten kent: filosofie, theologie, recht en geneeskunde. Binnen de filosofische faculteit komt datgene tot ontwikkeling wat wij nu exacte wetenschap noemen, zij het dat van een duidelijke arbeidsdeling vooralsnog geen sprake is. Kant schrijft naast zijn beroemde filosofische kritieken ook een verhandeling over de beweging van hemellichamen.

Waar disciplinaire grenzen nog ontbreken, verlopen de carrières van wetenschapsmensen langs andere lijnen, heeft de communicatie tussen geleerden een ander karakter en verschilt ook hun omgang met kennis. Tot in de $18 \mathrm{e}$ eeuw zijn althans de doorsnee academici geen onderzoekers maar schrijvers van leerboeken en compendia. Het is niet hun opgave nieuwe kennis te vergaren; zij presenteren en becommentariëren veeleer de zekerheden van hun voorgangers. Het woord discipline heeft voor hen dan ook nog de Latijnse betekenis van een 'disciplina', een op het onderwijs afgestemde pendant van een 'doktrina'. Disciplines zijn in dit geval overzichtelijke leereenheden die op hun beurt onderdeel zijn van een vaste, transcendente orde."

Kent het universum zo'n onveranderlijke orde, dan moet het mogelijk zijn de onderlinge verhouding tussen de verschillende wetenschappen voor eens en voor altijd vast te leggen. Dat is dan ook eeuwenlang geprobeerd. De geschiedenis van de filosofie 
kent een rijke traditie van pogingen de wetenschappen te inventariseren en te classificeren. Niet alleen Plato en Aristoteles, maar ook latere filosofen als Bacon, Wolf, Hegel en Bentham hebben geprobeerd de in hun tijd bekende wetenschappen overzichtelijk in te delen. ${ }^{2}$

In de $19 \mathrm{e}$ eeuw krijgt het genre van de classificatie van wetenschappen een nieuwe impuls door de opkomst van het positivisme. Vertegenwoordigers van deze filosofie proclameren de methodische eenheid van alle wetenschappen en proberen op grond van dat principe alle vormen van kennis binnen én hiërarchische orde te plaatsen. In de handen van de positivist krijgt het gebouw van de wetenschap de vorm van een pyramide. De bekendste poging de wetenschappen vollgens positivistische maatstaven in te delen, is zonder twijfel het ingenieuze systeem dat Auguste Comte in het midden van de $19 \mathrm{e}$ eeuw naar voren brengt. Hij ontwerpt een hiërarchie van wetenschappen die op twee ordeningsprincipes is gebaseerd: de mate van algemeenheid van kennis en de mate van complexiteit van het object van kennis. De sequentie van wetenschappen die Comte op grond van deze beide criteria samenstelt - wiskunde, astronomie, fysica, chemie, fysiologie en sociale fysica - is er een van afnemende algemeenheid en toenemende complexiteit, Dit indelingsvoorstel is lange tijd een belangrijk onderwerp van filosofisch debat geweest. Een groot aantal auteurs heeft geprobeerd Comtes systeem verder te verfijnen, anderen hebben alternatieve classificaties ontworpen. Maar tegelijkertijd groeit in de $19 \mathrm{e}$ eeuw ook de skepsis tegenover het genre als zodanig. Classificatieschema's mogen een zeker praktisch nut hebben - ze kunnen bij voorbeeld dienen als richtsnoer voor het indelen van bibliotheken - maar of ze daarnaast ook enige filosofische betekenis bezitten is twijfelachtig. ${ }^{3}$

De verminderde belangstelling voor traditionele classificatievraagstukken wijst op een diepgaande verandering in de wetenschappelijke wereld. Wanneer het geheel van onderling samenhangende leergebieden verandert in een systeem van relatief autonome disciplines, verdwijnt als het ware het centrale punt van waaruit men wetenschappen kan classificeren. Terwijl 18e-eeuwse filosofen zich nog als de woordvoerders van de wetenschap beschouwen en op grond van die functie alle wetenschappelijke kennis ordentelijk in het gelid zetten, heeft de wetenschappelijke wereld sedertdien in betrekkelijk korte tijd een meer decentrale structuur gekregen. Door arbeidsdeling en toenemende specialisatic wordt het (filosofische) verlangen naar een overkoepelende instantie, die zou kunnen bepalen hoe vakgebieden zich tot elkaar moeten verhouden, steeds meer een illusie. Wanneer wetenschappen zich gaan presenteren als disciplines in de moderne zin van het woord, doet in plaats daarvan het principe van soevereiniteit zijn intrede in de wetenschappelijke wereld. Zo behoort het tot de kenmerken van een moderne discipline dat haar leden zich niet door buitenstaanders de wet willen laten voorschrijven.

In de $20 \mathrm{e}$ eeuw zijn disciplines als de fysica, de chemie, de biologie, de psychologie, de economie en de sociologie uitgegroeid tot omvangrijke en tamelijk losse conglomeraten waarbinnen zich allerlei specialismen en afzonderlijke wetenschappelijke gemeenschappen hebben gevormd. Dit proces van differentiatie neemt echter niet weg dat disciplines de primaire eenheden zijn gebleven waarin wetenschappers worden opgeleid en kennis wordt gecodificeerd. Ten opzichte van elkaar hebben disciplines een eigen identiteit 
ontwikkeld die maakt dat we kunnen spreken van bij voorbeeld biologische, economische en sociologische kennis. Maar deze ontwikkeling roept ook nieuwe wetenschapstheoretische problemen op. Zo kunnen we ons afvragen waarop de verschillen in identiteit tussen disciplines eigenlijk zijn gebaseerd. Twee opvattingen treffen we nog altijd veelvuldig aan.

\section{Legpuzzelmodel}

De eerste is dat de identiteit van elke afzonderlijke discipline grotendeels wordt vastgelegd door het object dat ze bestudeert. De astronomie gaat over hemellichamen, de geologie over gesteentes, de literatuurwetenschap over literatuur, terwijl de psychologie de menselijke psyche behandelt en de sociologie zich op sociale verschijnselen richt. Elke discipline bestrijkt zo een deel van de werkelijkheid.

Deze opvatting kunnen we het legpuzzelmodel van disciplines noemen. Wanneer iedere discipline inderdaad een deel van de werkelijkheid voor haar rekening neemt, dan mogen we immers verwachten dat de binnen elke discipline vergaarde kennis min of meer op elkaar aansluit, net zoals de stukjes van een legpuzzel dat doen. ${ }^{5}$ Iedereen die wel eens over de grenzen van zijn eigen discipline heeft gekeken, weet echter dat dit in de praktijk niet zo is. Anders dan het legpuzzellmodel suggereert, laat kennis die uit verschillende disciplines afkomstig is; zich meestal niet zonder meer tot een geheel samenvoegen. Biologisch, psychologisch en sociologisch onderzoek naar emoties bij voorbeeld vult elkaar allesbehalve eenvoudig aan; wie de verschillende inzichten op dit gebied met elkaar vergelijkt, bemerkt snel dat de stukjes niet uit dezelfde doos afkomstig zijn. $^{6}$

Het legpuzzelmodel zet ons op nog meer manieren op het verkeerde been. Het wekt, om te beginnen, de indruk dat het object van een discipline een vanzelfsprekend gegeven is. Maar dat is niet het geval. Vormen alleen literaire teksten het object van de literatuurwetenschap, of dient dit vak alle vormen van fictie te bestuderen? Moet de literatuurwetenschap zich op teksten richten of op de lezers van die teksten? Door dit soort twisten wordt iedere discipline bij herhaling getroffen, natuurwetenschappelijke disciplines niet uitgezonderd.

Daar komt bij dat het object van een discipline ook vanuit historisch oogpunt geenszins een onveranderlijk gegeven is. Wanneer er nieuwe theorieèn of onderzoekspraktijken ontstaan, verandert meestal ook het object van karakter. De psychologie was een eeuw geleden geen sociale wetenschap en al helemaal geen gedragswetenschap, maar een wetenschap die de werking van de menselijke geest bestudeerde. De geologie had tot het moment waarop de theorie van de schuivende continenten ingang vond met oceanografie weinig uit te staan.

\section{Loketmodel}

Naast het legpuzzelmodel doet nog een tweede opvatting de ronde over wat disciplines eigenlijk zijn. Deze komt neer op het idee dat de identiteit van een discipline wordt bepaald door de problemen die ze zich stelt. Welk deel van de werkelijkheid disciplines bestrijken, is slechts van secundair belang. Soms richten disciplines zich immers op hetzelfde gebied. Nee, waar het vooral om gaat zijn het soort problemen die binnen een discipline worden geformuleerd en het type kennis waarin men is geinteresseerd. Wie wil 
weten hoe organismen interacteren met hun omgeving, moet zich wenden tot de biologie; wie iets wil weten over de moleculaire structuur van organismen, dient bij de chemie aan te kloppen. ${ }^{7}$

Helaas is dit loketmodel van disciplines niet minder misleidend. Disciplines ontwikkelen zich en in dat proces veranderen meestal ook de problemen en de kennis waarin men geinteresseerd is. Bovendien bestaan er bij herhaling verschillen van mening over het soort problemen dat een discipline dient te behandelen en het type kennis dat verworven dient te worden. Buiten dat is ook de taakverdeling tussen disciplines vaak onderwerp van debat. Biologen en chemici twisten over de kwestie tot welke discipline immunologische vraagstukken allereerst behoren. Filosofen, historici, psychologen en sociologen ruzieen over de vraag hoe kennis zich ontwikkelt. Anders dan het loketmodel doet verwachten, worden we in de wetenschap regelmatig van het kastje naar de muur gestuurd:

\section{Zoeken naar metahistorische grondslagen}

Dat de twee besproken opvattingen over de aard van disciplines gelijksoortige problemen oproepen, is niet zo verwonderlijk In beide gevallen wordt naar een onafhankelijke grondslag voor de disciplinaire arbeidsdeling gezocht, iets wat met name bij het legpuzzelmodel meteen in het oog springt. Wie volgens dit model redeneert, gaat ervan uit dat in de manier waarop de wetenschap is georganiseerd een of andere objectieve structuur tot uitdrukking komt die in de realiteit zelf verborgen ligt.

Deze veronderstelling sluit aan bij de traditie van de wetenschapsclassificatie. Bovendien komt ze overeen met de intuïtie van veel wetenschapsmensen. Volgens deze intütie vereist wetenschap immers bovenal deemoed: een goed onderzoeker laat de werkelijkheid spreken, hij onderwerpt zich zoveel mogelijk aan de stem van de empirie. Dit beeld, dat objectiviteit met passieloos schouwen verbindt, versterkt de gedachte dat ook de manier warop de wetenschap in disciplines is verdeeld ons grosso modo door de werkelijkheid zelf is opgelegd.

Dat deze gedachtengang problemen oproept, wordt door sommigen wel onderkend. Maar die problemen worden meestal ook weer snel terzijde geschoven, waarschijnlijk omdat men er, gegeven het beeld van de deemoedige, schouwende wetenschapper, geen raad mee weet. Ik geef een voorbeeld.

De socjologen Van Doorn en Lammers stellen in het begin van hun bekende handboek Modeme Sociologie vast dat de sociale werkelijkheid drie dimensies kent: de persoon, de maatschappij en de cultuur. Vervolgens wordt opgemerkt dat deze onderscheiding is verdisconteerd in het drietal van psychologie, sociologie en cultuurkunde". Cultuurkunde? Inderdaad, de indeling veroorzaakt (...) enige moeilijkheden bij de omgrenzing van de cultuurwetenschap', geven de auteurs toe. Maar Van Doorn en Lammers tillen daar niet zwaar aan. Want deze moeilijkheden duiden in hun ogen hoofdzakelijk op het feit dat de opbouw van de menswetenschappen nog niet geheel en al aansluit bij de structuur van de sociale werkelijkheid. 'Een moederwetenschap der cultuurkunde of "culturologie" ontbreekt voorshands", schrijven ze.

We kunnen echter ook een andere conciusie trekken. Want zijn de moeilijkheden waarop Van Doorn en Lammers stuiten niet vooral een bijprodukt van hun werkwijze? Ze proberen een ontologisch antwoord te geven op de vraag waarom de wetenschap- 
pelijke wereld tegenwoordig $z \sigma$ is ingedeeld dat we wel algemene disciplines kennen als de psychologie en de sociologie maar geen discipline als de culturologie'; een antwoord dus waarin naar de structuur van de werkelijkheid wordt verwezen. Maar misschien moeten we het antwoord in een andere richting zoeken en zijn onderscheidingen als die tussen persoon, maatschappij en cultuur niet in de structuur van de realiteit ingebakken, maar veeleer het resultaat van een historisch proces dat mede door de menswetenschappen is beïnvloed. Zo bezien ontbreekt het ons niet aan een 'culturologie' omdat 'cultuur' van nature een vager en meer omvattend gebied is dan 'persoon' of 'maatschappij'. Het omgekeerde is eerder waar: ons begrip van cultuur is juist zo breed omdat dit gebied door een groot aantal zelfstandige disciplines wordt bestreken en we geen overkoepelende discipline kennen die cultuurkunde, culturwetenschap dan wel culturologie heet.

Alhoewel dit soort vermoedens tegen het intuitieve beeld van wetenschap indruisen, worden ze bevestigd door historisch onderzoek naar de natuurwetenschappen. Ook het onderscheid tussen fysische, chemische en biologische verschijnselen lag niet klaar om te worden ontdekt; de vorming van dit onderscheid ging geenszins vooraf aan het proces waarin de natuurwetenschap veranderde in een stel aparte disciplines. Beide ontwikkelingen vonden tegelijkertijd plaats."

Het loketmodel van disciplines is op dit punt minder nallef. Het neemt niet aan dat de disciplinaire arbeidsdeling simpelweg de structuur van de werkelijkheid weerspiegelt, maar gaat ervan uit dat wij, mensen, op grond van onze interesses en de problemen die we ons stellen de studie van de realiteit zelf in vakgebieden indelen. Desalniettemin mondt ook deze benadering snel uit in een zoektocht naar een onafhankelijke grondslag voor disciplinevorming, met name wanneer die interessen en problemen een onveranderlijk karakter worden toegeschreven. In dat geval postuleert men achter de historische veranderlijke verschijningsvorm van een discipline toch weer een metahistorische essentie, zij het op een wat andere manier dan de aanhangers van het legpuzzelmodel dat doen. Ik geef weer een voorbeeld uit de geschiedenis van de sociologie.

Het kernprobleem van de sociologie is het vraagstuk van de sociale orde, zo is ondermeer door de Amerikaanse socioloog Talcott Parsons betoogt. ${ }^{10}$ Historische veranderingen en ontwikkelingen binnen het vak, zo meent hij, nemen niet weg dat de identiteit van de sociologie sinds jaar en dag wordt vastgelegd door haar studie van het ordeprobleem. Een dergelijke stellingname heeft echter als bezwaar dat ze weinig gewicht toekent aan het feit dat in het verleden niet steeds op dezelfde manier en niet steeds met dezelfde oogmerken over 'sociale orde' gesproken is. De omgang met dit probleem en de wijze waarop ze is gearticuleerd en geformuleerd vertoont juist een grote mate van variatie. Wie gegeven zulke verschillen desalniettemin meent te kunnen spreken van het probleem van sociale orde, heeft onvoldoende weerstand kunnen bieden aan wat de filosoof Ludwig Wittgenstein 'ons sterke verlangen naar algemeenheid' heeft genoemd. Wanneer we bepaalde probleemformuleringen met behulp van eén algemene term kunnen typeren, concluderen we al snel dat ze dus een gemeenschappelijk element moeten bezitten. Maar met het probleem van sociale orde is het niet anders gesteld dan met de algemene term 'spel', Wittgensteins bekende voorbeeld. Zulke algemene aanduidingen wijzen niet op het bestaan van een invariante essentie, op de aanwezigheid van een bepaalde kernbetekenis die door de geschiedenis heen steeds gelijk gebleven is, 
hoe zeer de formulering ervan ook verschillen mag. De sociologische gewoonte om over het probleem van sociale orde te spreken doet hoogstens vermoeden dat er tussen de verschillende probleemformuleringen, die in de loop der tijd naar voren zijn gebracht, een zekere familiegelijkenis bestaat. ${ }^{11}$

\section{Demarcatie}

De bezwaren die tegen de manieren van redeneren van zowel Van Doorn en Lammers als van Parsons naar voren zijn gebracht, tasten de beide genoemde modellen in de wortel aan. Ze maken het immers onmogelijk onverkort vast te houden aan de gedachte dat de disciplinaire arbeidsdeling een of ander metahistorisch fundament kent. Er blijkt geen historische rechtvaardiging te bestaan voor onze neiging disciplines te beschouwen als 'natural kinds', als eenheden die zich op grond van enkele onveranderlijke kenmerken van elkaar laten onderscheiden. ${ }^{12}$

Dit inzicht sluit aan bij nieuwe ideeen over wat onder wetenschapsfilosofen te boek staat als het demarcatievraagstuk. Een van de belangrijkste motieven om binnen de filosofie een specialisme te ontwikkelen dat 'wetenschapsfilosofie' heet, was de overtuiging dat 'wetenschap' (of tenminste 'natuurwetenschap') een natuurlijke eenheid vormt; een gebied dat op grond van een beperkt aantal welomschreven kenmerken van de rest van de cultuur is af te bakenen. Wetenschap onderscheidt zich in de moderne tijd van andere cultuuruitingen door haar methode of door haar speciale relatie tot de werkelijkheid, zo werd gesteld. De uitkomsten van recent wetenschapssociologisch onderzoek naar de praktijk van wetenschapsontwikkeling bevestigen deze stelling echter niet. Anders dan met name leerboeken suggereren, wordt het feitelijk handelen van onderzoekers niet geleid door metahistorische regels. Wetenschap bedrijft men altijd binnen de context van specifieke tradities, ic. een geheel van kenmerkende voorbeelden, handelingsvoorschriften, redeneerpatronen en omgangswormen. Onderzoek naar wetenschap moet daarom niet gericht zijn op het preciseren van tijdloze demarcatiecriteria maar heeft tot taak te verhelderen hoe zulke historische tradities van wetenschapsbeoefening ontstaan en veranderen. ${ }^{13}$

Het voorstel om disciplines niet langer naar analogie van natuurlijke eenheden of soorten te behandelen, heeft een soortgelijke consequentie. De huidige identiteit van een discipline moeten we niet langer zoeken in de aard van haar object of in het type problemen dat ze behandelt, maar in de geschiedenis van die discipline. Identiteit is ook voor een discipline geen van buiten opgelegd gegeven, maar iets wat door haar leden in de omgang met het verleden en met tijdgenoten verworven wordt.

Dit boek documenteert enkele episoden uit de worsteling van sociologen een collectieve identiteit te verwerven. Deze studie richt zich niet op de groei van sociologische kennis, maar stelt de vraag hoe en in welke zin 'sociologie' tussen 1870 en 1930 de vorm kreeg van een discipline. Het onderzoek beperkt zich, zoals al in het voorwoord is opgemerkt, tot twee landen: de Verenigde Staten en Duitsland. De manier waarop 'sociologie' zich in Amerika heeft geprobeerd te vestigen, de relatie tussen het door Max Weber aangezwengelde waardevrijheidsdebat en de opkomst van de sociologie in Duitsland, de pogingen die sociologen hebben ondernomen om hun discipline wetenschappelijk aanzien en cultureel gezag te doen verkrijgen, zijn onderwerpen waarover ik zal 
uitweiden. Toch heb ik me niet uitsluitend door historische interesses laten leiden. Zoals uit het vervolg van dit hoofdstuk duidelijk zal worden, valt hier het accent op wetenschapstheoretische en geschiedtheoretische vraagstukken. Dit onderzoek hoopt bij te dragen aan hedendaagse discussies over de ontwikkeling van wetenschap en de wijze waarop haar geschiedenis bestudeerd moet worden.

\section{De geschiedenis van disciplines: identiteit en continuîteit van de sociologie}

In 1822 schrijft Auguste Comte een lang essay waarin hij een ingrijpende hervorming van de Franse samenleving bepleit. ${ }^{14}$ De maatschappij, zo houdt hij zijn lezers voor, bevindt zich in een diepe crisis en adel noch burgerij weet hoe zij kan worden overwonnen. Terwijl de adel slechts terug verlangt naar het feodale verleden, stelt de burgerij zich tevreden met afbrekende kritiek op het feodale systeem. Een positieve instelling ontbreekt. Welbeschouwd is dat ook niet zo verwonderlijk, want wie de maatschappij werkelijk wil hervormen, dient te beschikken over de nodige wetenschappelijke kennis en juist die kennis is niet of nawwelijks aanwezig. In burgerlijke kringen ziet men de politiek als een praktische aangelegenheid, als iets waar de wetenschap buiten staat. Een grote dwaling, meent Comte. De hervorming van de maatschappij kan geenszins worden overgelaten aan 'une assemblee d'orateurs'. Ze is primair een taak voor geleerden; slechts zij mogen in staat worden geacht van de politiek een wetenschap te maken.

Politiek verheffen tot wetenschap betekent voor Comte vooral dat politiek handelen niet langer wordt opgevat als een opzichzelfstaande activiteit. De politieke orde is een uitdrukking van de civiele orde, die op haar beurt slechts de stand van de civilisatie uitdrukt. Een juiste en ook effectieve politiek is daarom pas mogelijk wanneer eerst de fundamentele wetten van de mensellike beschaving zijn blootgelegd. Helaas wordt deze volgens Comte evidente warheid niet algemeen gedeeld. Niet alleen in adellijke en burgerlijke kringen heerst een 'esprit superficiel', ook historici gaan oppervlakkig te werk door zich enkel te richten op de daden van enkele hoofdfiguren wit de geschiedenis. $\mathrm{Zij}$ zien allen de spelers voor het stuk aan.

\section{Disciplinegeschiedenis}

Comtes betoog is sociologen bekend; het makt deel uit van hun disciplinegeschiedenis, een vorm van geschiedschrijving die in de regel beofend wordt door wetenschappers die zelf in de betreffende discipline zijn opgeleid. ${ }^{15}$ Geschiedenissen van de psychologie zijn meestal van de hand van psychollogen, economen beheersen de geschiedenis van de economie en auteurs van studies over de geschiedenis van de sociologie zijn bijna altijd zelf opgeleid tot socioloog.

Deze nawwe band tussen een discipline en haar geschiedschrijving leidt vaak tot een rechtlijnige kijk op het verleden. De geschiedenis van de sociologie, zo schrijven bij voorbeeld de sociologen Collins en Makowsky in hun handboek The Discovery of Society, vormt een langdurige, moeizame poging tot bewustwording van het verborgene of vanzelfsprekende; (...) Sinds de dagen dat het denken over de samenleving weinig meer 
was dan cen samenraapsel van mythen, ideologieèn en speculatieve ideeën, hèbben we de ene illusie na de andere doorbroken en bij elke geslaagde ondermijning van het geloof der vaderen iets nieuws en duurzaams ontdekt:" ${ }^{16}$ De geschiedenis van de sociologie staat bij Collins en Makowsky geheel in het teken van de vooruitgang. Sociologen zijn mensen die licht brengen in de maatschappelijke duisternis; nadat Comte de maatschappij had ontdekt, brachten latere generaties sociologen dit nieuwe veld van onderzoek stap voor stap steeds beter in kaart.

Sociologen die Comte als een van de grondleggers van hun discipline beschouwen, zijn over het algemeen geenszins blind voor de in zijn werk aanwezige politieke retoriek; zijn conservatisme wordt in disciplinegeschiedenissen zeker niet genegeerd. Maar hoe breed uitgemeten ook, de geschiedschrijving van de sociologie behandelt Comtes retoriek toch hoofdzakelijk als tijdgebonden ruis; de enkele waardevolle inzichten die we uit zijn werk kunnen opdiepen, zijn van meer belang. In de kronieken van de discipline wordt het wetenschappelijk signaal aldus zo veel mogelijk gescheiden van atmosferische storingen. Comte mag allerlei twijfelachtige opinies bezitten, dit neemt niet weg dat hij als een der eersten heeft ingezien dat de maatschappij op wetenschappelijke wijze kan worden bestudeerd. 17

Maar hoe weten we eigenlijk wat bij Comte ruis is en wat signaal? Dat onderscheid is gebaseerd op latere ontwikkelingen binnen de sociologie. Precies datgene wat in zijn werk aansluit bij wat men tegenwoordig voor waar of waardevol houdt, wordt naar voren gehaald. Dat geldt ook voor de metaforen die hij gebruikt in 'Plan des travaux nécessaires pour organiser la societe', Comtes zoeven aangehaald essay. De metafoor van thet toneel, van de spelers en het stuk, is zonder twijfel de meest suggestieve. Wie niet beseft dat de acteurs een stuk aan het spelen zijn; is een oppervlakkige toeschouwer, iemand die geen oog heeft voor de samenhang van de scènes en de ontwikkeling wan de karakters. Misleid wellicht door het levendige spel, ziet men niet dat in feite alles op papier staat en dus reeds van te voren is vastgelegd. Met behulp van deze metafoor, deze analogie van toneel en samenleving, makt Comte van zijn opponenten naïeve geesten die men onmogelijk serieus kan nemen. De 'burgerlijke' intellectuelen die Comte aanvalt, hebben een andere visie op de politiek dan hij, maar deze botsing van opinies verschijnt in de tekst als een strijd tussen licht en duister, tussen wetenschappelijke scherpzinnigheid en gedachteloze oppervlakkigheid. Lezen we selectief en accepteren we dit soort voorstellingen van zaken, dan krijgt de geschiedenis van de sociologie snel het karakter van een legende. ${ }^{18}$ De zegetocht waar Collins en Makowsky verslag van doen, is daar een voorbeeid van.

\section{Finalisme}

The Discovery of Society van Collins en Makowsky biedt een handzame geschiedenis van de sociologie. Door een selectieve leeswijze van historische teksten slagen de auteurs er in verschillende activiteiten uit verschillende eeuwen onder te brengen in én verhaal. Dergelijke verhalen, ook wanneer ze niet onmiddellijk een hedlendaags standpunt legitimeren, verschaffen de socioloog een geordend verleden en daarmee een omschreven identiteit. De geschiedenis heeft zin gekregen, omdat men haar continuitteit heeft gegeven. $^{19}$

Continuiteit met het verleden wordt in disciplinegeschiedenissen gewoonlijk op een 
finalistische manier aangebracht. Dat wil zeggen: het verhaal wekt de indruk dat de discipline zich volgens een gereedliggende blauwdruk stapsgewijs heeft ontwikkeld. ${ }^{20}$ Het boek van Collins en Makowsky kent zo'n opzet. Maar ook twee Nederlandse pogingen om de geschiedenis van de sociologie een geordend en samenhangend aanzien te geven, kunnen dit finalisme illustreren.

In de Sociologische Encyclopedie van 1978 lezen we onder het trefwoord Sociologie, Geschiedenis van de - : 'In de ontwikkeling van de sociologie kan men drie fasen onderscheiden, waarin achtereenvolgens de begrippen maatschappij, sociologie en socioloog opkomen. In de $18 \mathrm{e}$ eeuw komt men tot de ontdekking, dat er zoiets bestaat als een sociale werkelijkheid, die kan worden aangeduid als maatschappij. In de $19 \mathrm{e}$ eeuw worden vervolgens pogingen ondernomen om een program van de sociologie als wetenschap van de maatschappij uit te werken. De pioniers van de sociologie zijn eenlingen, die weinig of geen contact met elkaar onderhouden. Ze zijn bovendien autodidact en staan buiten de universiteit. De volgende generatie beoefenaars der sociologie bestaat weliswaar uit universitaire docenten, maar deze hebben - met uitzondering van Durkheim - geen sociologie als leeropdracht. Als universitair leervak is de sociologie nog betrekkelijk jong. Pas in onze eeuw ontwikkelt ze zich van een roeping tot een beroep. Dat is zowel het gevolg van haar wetenschappelijke vorderingen als van een aantal maatschappelijke veranderingen. In de moderne verzorgingsstaat is er in toenemende mate behoefte aan sociologen'.21

Bij de auteur van dit encyclopedie-artikel, B.C. van Houten, vinden we een veronderstelling die we ook wel in geschiedenissen van landen of volken aantreffen: de gedachte dat een 'volk' of een 'natie' waarvan de geschiedenis beschreven wordt, iets in de werkelijkheid van het verleden is dat een definieerbare identiteit bezit. ${ }^{22}$ 'Sociologle' verschijnt in de tekst als een entiteit die op een goed moment in het verleden opduikt en die daarna tot in het heden te volgen is. Dit wordt mogelijk gemaakt door aan "sociologie" een onveranderlijk kenmerk toe te kennen: sociologie is de (wetenschappelijke) studie van de maatschappij. Wat bij alle historische veranderingen constant blijft, is haar object; daarin ligt de identiteit van het vak verankerd. Door op deze manier te beginnen met het vastleggen van de identiteit van het vak en zo aan te sluiten bij het legpuzzelmodel van disciplines, beschikt de historicus van de sociologie over een eenduidig principe voor het ordenen en interpreteren van zijn historisch materiaal. Allerlei uiteenlopende intellectuele activiteiten worden uit het verleden gelicht en vervolgens onder eén noemer gebracht door ze te interpreteren als bijdragen aan een en hetzelfde project: de wetenschappelijke bestudering van de maatschappij. ${ }^{23}$

Laeyendecker, auteur van een veel gebruikte inleiding tot de geschiedenis van de sociologie, brengt op een andere manier lijn in de geschiedenis van zijn vak. In zijn handboek Orde, Verandering, Ongelijkheid ontleent de sociologie haar identiteit niet aan een onveranderlijk object, maar aan de continue aandacht voor een drietal problemen: 'In feite keren dezelfde problemen, zij het steeds in enigszins andere gedaante terug. (...) Hier worden zij aangeduid met de sleutelwoorden orde, verandering en ongelijkheid. De verschillen tussen sociologen doen zich voor als er een antwoord moet worden gegeven op de vragen hoe de orde in de samenleving verklaard moet worden, hoe de verandering moet worden begrepen en waarom er maatschappelijke ongelijkheid is ${ }^{24}$ Door aldus uit te gaan van drie fundamentele problemen die sociologen verschillend benaderen - een 
aanpak die meer met het loketmodel van disciplines overeenstemt - is Laeyendecker in staat recht $t e$ doen aan het onmiskenbaar pluriforme karakter van de geschiedenis van de sociologic, terwijl hij het idee dat deze geschiedenis een duidelijke continuinteit bezit niet hoeft op te geven.

Toch vertoont ook Laeyendeckers geschiedschrijving finalistische trekken. Her lijkt alsof sociologie al direct bij haar geboorte een eigen identiteit bezat, door Laeyendecker omschreven in termen van enkele kemproblemen. In de tijd die daaraan voorafging, was het wachten slechts op de condities waaronder die identiteit gestalte kon krijgen. Na de Renaissance, zo schrijft hij bij voorbeeld, 'zou het nog een tijd duren voordat de empirische maatschappijwetenschap tot ontwikkeling zou komen. Dat kon pas gebeuren toen twee (...) voorwaarden waren vervuld, namelijk het besef dat er een maatschappij was om te bestuderen en de psychologische houding van distantie ten aanzien van het studie-object*2s

Laeyendecker schrijft dat de sociologie in de context van de maatschappij (moet) worden bestudeerd". Maar omdat hij het vak een nagenoeg onveranderlijke identiteit toemeet, kan in zijn boek die context alleen maar een voorwaardenscheppende rol spelen. Het groeiend besef dat men de maatschappij wetenschappelijk kan bestuderen en het toenemend vermogen afstand te kunnen nemen van de eigen samenleving figureren in zijn betoog slechts als de uiterlijke condities voor een steeds betere behandeling van de drie genoemde fundamentele sociologische problemen.

In de beide besproken vormen van finalistische geschiedschrijving van de sociologie komen respectievelijk het legpuzzelmodel en het loketmodel van disciplines tot uitdrukking. Van Houten en Laeyendecker komen er daardoor niet aan toe de identiteit van hun discipline werkelijk te problematiseren; in plaats daarvan zijn hun verhalen opgebouwd rond een reeds bij voorbaat gegeven definitie van die identiteit. Daaraan kunnen we een tweede conclusie toevoegen. Tussen de omgang met het identiteitsprobleem en de behandeling van historische continuitteit blijkt in beide gevallen een nauw verband te bestaan. Zowel Van Houten als Laeyendecker trekken vrij cenvoudig een rechte (opgaande) lijn tussen het verleden en het heden van hun vak. Dat is ook niet verwonderlijk, want wie de identiteit van zijn discipline niet problematiseert, zal gewoonlijk ook niet uitgebreid stilstaan bij continuïteitsproblemen. Staat die identiteit bij voorbaat vast, dan lijkt het immers alsof continuîteit gemakkelijk is aan te wijzen.

\section{De status van disciplines: legitimiteit en autoriteit van de sociologie}

Nadat in de eerste helft van de $19 \mathrm{e}$ eeuw de natuurwetenschappen een disciplinaire vorm hebben aangenomen, brëidt de disciplinaire organisatie zich ook uit tot de menswetenschappen. Er vormen zich gemeenschappen van professionele onderzoekers die zelfstandige vakgebieden doen ontstaan als de geschiedwetenschap, de economie, de psychologie en de sociologie. Naar het voorbeeld van de disciplinevorming in de natuurwetenschappen proberen deze gemeenschappen een eigen, soeverein domein voor onderwijs en onderzoek af te bakenen, spannen zij zich in om binnen dit domein eenduidige standaar- 
den te ontwikkelen voor competent onderzoek en ware kennis en stellen zij tenslotte alles in het werk om op het kennisgebied warover zij aldus het beheer opeisen een onderscheid aan te brengen tussen professionele 'kennis' en niet-professionele 'opinie'.

Op al deze punten zijn de niet-naturwetenschappelijke disciplines globaal gezegd minder succesvol gebleken dan de natuurwetenschappelijke disciplines. Dat over de deskundigheid van fysici en de waarheid van naturkundige kennis slechts andere fysici kunnen oordelen, wordt door weinigen ter discussie gesteld, maar zo'n status heeft bij voorbeeld de sociologie zich niet kunnen aanmeten. Niet iedere aanspraak op disciplinaire soevereiniteit heeft, anders gezegd, een even grote mate van legitimiteit verworven. Zo behoort het tot de Nederlandse intellectuele folklore dat Jan Blokker de sociologie af en toe op ironie onthaalt. Maar we kunnen dit verschijnsel niet eenvoudig terugvoeren op de toevallige hebbelijkheden van een columnist. Blokker staat met zijn spot in een lange traditie; vanaf het moment dat de sociologie zich als een zelfstandige wetenschap gaat presenteren, wordt ook de legitimiteit van het vak in twijfel getrokken.

Aan het begin van deze eeuw merkte een frans criticus van de sociologie eens snedig op: 'Sociologen denken dat het voor het begrijpen van de menselijke samenleving toereikend is om socioloog te zijn - alsof voor wie die dapper will zijn het aantrekken van een uniform voldoende is'. ${ }^{26}$ Ook in romans of literaire essays zijn herhaaldelijk schampere opmerkingen richting sociologie te vinden. Een karakteristiek voorbeeld levert Graham Greene in Getting to Know the General: 'She seemed at that first meeting a little pretentious and a would-be intellectual - she was studying sociology in the States, a subject which thrives on banalities and abstract jargon - but I was quite wrong about her'. ${ }^{27}$

Aanvallen op de sociologie komen niet alleen uit journalistieke of literaire hoek. Ook uit aangrenzende wetenschappelijke disciplines hoort men regelmatig kritische of skeptische geluiden. Het volgende citaat, afkomstig van een econoom, geeft de teneur daarvan goed weer: 'I $k$ heb me de laatste tijd (...) in de sociologische literatuur verdiept en mijn ervaring is dat de sociologie penetreert op het gebied van economie en recht. $\mathrm{k}$ heb dan het gevoel, $\mathrm{ja}$, wat is het toch eigenlijk, het is wat simpele economie, de begrippen worden wat uitgerekt, en het is wat simpel recht, en die begrippen worden ook wat uitgerekt". 28

Overigens laten ook sociologen zich niet onbetuigd bij pogingen andere disciplines een toontje lager te laten zingen. Aangeroerd is al de minachting waarmee Comte spreekt over historici uit zijn tijd, een houding die sociologen nadien vaker hebben ingenomen. Rivaliteit tussen disciplines is een terugkerend verschijnsel. Met name wanneer een nieuwe discipline zich wil vestigen of haar werkterrein wenst uit te breiden, kan de concurrentiestrijd soms fel oplaaien. In dergelijke gevechten is ook de sociologie meermalen betrokken geweest en ook nu nog neemt ze eraan deel.

In de vormen van finalistische geschiedschrijving die hierboven zijn besproken, is er voor rivaliteit tussen disciplines weinig aandacht. Het legpuzzel-en het loketmodel van disciplines suggereren immers dat de arbeidsdeling tussen disciplines reeds min of meer als een soort blauwdruk in de geschiedenis klaar lag. De historische context is weliswaar belangrijk, maar speelt louter een voorwaardenscheppende rol voor het realiseren van die blauwdruk. Dat er zoiets als de sociologie is ontstaan, spreekt voor de finalistische historicus dan ook vanzelf: ze 'moest' op een gegeven moment wel ontstaan, het wachten 
was slechts op de intellectuele en sociale voorwaarden waaronder het vak ook daadwerkelijk kon ontstaan. Wanneer men een discipline reeds vooraf een eigen identiteit toekent, staat kortom ook haar legitimiteit niet ter discussie.

\section{Twee gangbare kennistheoretische uitgangspunten}

Voorzover de terugblik van een socioloog op de geschiedenis van zijn vak niet meer is dan een preek voor eigen parochie, hoeft het niet te verbazen dat de vraag hoe de sociologie zich een academische status heeft proberen te verwerven, niet wordt gesteld. De legitimiteit van de eigen discipline staat dan simpelweg als een onuitgesproken uitgangspunt voorop. Maar het zou onbillijk zijn om een genre louter op basis van enkele handboeken te bekritiseren. Op het gebied van de geschiedenis van de sociologie beschikken we tevens over allerlei kritische studies waarin de status van de sociologie als discipline wel wordt geproblematiseerd. ${ }^{29}$ Toch wordt ook daarin niet altijd voldoende afstand genomen van het legpuzzel- en het loketmodel van disciplines. Daarin slaagt men met name niet wanneer vastgehouden wordt aan de kennistheoretische veronderstellingen die achter beide modellen schuil gaan.

In het genre van de disciplinegeschiedenis bekennen auteurs zich lang niet altijd expliciet tot eén bepaalde kennisleer. Vaak overheerst een eclectische houding en treffen we in een en dezelfde studie elementen uit verschillende wetenschapsfilosofische en kennistheoretische stromingen aan. Daarvan abstraheer ik hier door me te concentreren op twee onder sociologen gangbare 'ideaaltypische' kennistheoretische posities die finalistische geschiedschrijving in de hand werken: realisme en perspectivisme.

De realist vat wetenschapsbeoefening op als het gestaag in kaart brengen van de wereld. Buiten ons om is deze objectieve wereld volgens hem onderverdeeld in verschillende regio"s die elk tot object van onderzoek gemaakt kunnen worden; wanneer dit gebeurt ontstaat er een nieuwe wetenschap of discipline. Dat sommige wetenschappen van meer recente datum zijn dan andere verklaart de realist meestal door erop te wijzen dat niet alle delen van de wereld even gemakkelijk tot object van onderzoek kunnen worden. Men heeft daar namelijk een zekere distantie voor nodig en het kost minder inspanning die houding ten opzichte van de natuur te verwerven dan ten opzichte van de eigen samenleving. De maatschappij stond lange tijd als het ware te dicht bij ons om onderwerp te kunnen worden van wetenschappelijk onderzoek. ${ }^{30}$

Vanuit deze visie op wetenschap ligt het voor de hand de opkomst van de sociologie te verklaren in termen van een groeiend vermogen de maatschappij met een afstandelijke blik te bezien. Een historicus die deze verklaring opvoert, heeft weinig aandacht voor discussies over de legitimiteit van de sociologie. Kritiek op het vak interpreteert hij snel als historisch niet terzake doende uitingen van vooroordeel en obscurantisme die iedere voorwaartse wetenschappelijke stap nu eenmaal begeleiden.

Het realistische beeld van wetenschap is echter maar moeilijk in overeenstemming te brengen met de geschiedenis van de sociologie. Over hoe de samenleving functioneert kunnen sociologen het maar niet eens worden; het vak kent verscheidene stromingen en scholen die verschiliend denken over sociale verschijnselen. De realist rest in deze situatie slechts de hoop op betere tijden, een toekomst waarin de sociologie tot een echte wetenschap zal zijn uitgegroeid.

In vergelijking met de realist weet de perspectivist met het pluralisme in de sociale 
wetenschappen beter raad. De perspectivist gaat ervan uit dat kennis altijd vanuit een bepaald gezichtspunt, een perspectief verworven wordt. We staan in een denkstijl, een traditie, of, nog algemener, in een cultuur, en nemen van daaruit de dingen waar. Daarom is een veelheid van gezichtspunten te verkiezen boven het absolutisme van eên standpunt. De wereld laat zich immers beter bezien wanneer dit vanuit verschillende perspectieven gebeurt.

Tot relativisme behoeft dit pleidooi voor pluralisme niet te leiden. Relativistische consequenties kunnen vermeden worden door het letterlijk nemen van de optische metafoor die in het spreken over perspectieven besloten ligt. ${ }^{31}$ Radicale verschillen van mening kunnen dan bij voorbeeld worden opgevat als een botsing tussen meerdere eenzijdige visies op de werkelijkheid. De geloofwaardigheid die deze optische interpretatie zeker bezit, wordt voor een groot deel ontleend aan het feit dat ze aansluit bij de alledaagse ervaring dat objecten en gebeurtenissen vanuït verschillende gezichtspunten zijn waar te nemen. Van een huis zien we nooit tegelijk de voor- en achterkant, en de agent bekijkt een verkeersongeval nu eenmaal vanuit een andere hoek dan de arts. In de wetenschap, zo betoogt de perspectivist, gaat het niet wezenlijk anders toe. ledere theorie belicht altijd slechts bepaalde aspecten van de werkelijkheid; iedere wetenschapsbeoefenaar neemt vanuit zijn professionele achtergrond de dingen altijd selectief waar. Verschillende perspectieven onderling vergelijken is natuurlijk niet altijd even gemakkelijk, maar geenzins bij voorbaat onmogelijk. Als het zo is dat ieder perspectief cen eenzijdig beeld van de werkelijkheid biedt, dan kunnen ze elkaar immers in principe aanvullen, zodat er een meer volledig beeld van de werkelijkheid ontstaat. ${ }^{32}$

Ook tegen de achtergrond van dit perpectivisme blijft de legitimiteit van een discipline een probleem dat geen speciale aandacht behoeft. Want zeggen we eenmaal: 'Sociologen zijn het onderling oneens omdat ze hun object ("de maatschappij") vanuit een verschillend perspectief bezien', of 'Sociologen hebben de waarlijk sociologische problemen ("orde, verandering, ongelijkheid") steeds anders benaderd', dan ligt het in de lijn der dingen om van andere disciplines te zeggen: 'Zij bezien de realiteit op hun beurt vanuit een ander gezichtspunt en stellen zich andere problemen dan wij sociologen doen'. Zo opgevat vult iedere discipline andere disciplines in principe toch weer eenvoudig aan, net zoals de stukjes van een puzzel of de loketten van openbare diensten dat - als het goed is - doen. Rivaliteit tussen disciplines is voor de perspectivist dan ook slechts een uiting van kortzichtigheid, onbescheidenheid, eerzucht of een of andler persoonlijk belang; met de disciplinaire opbouw van wetenschap heeft ze weinig van doen.

\section{Pragmatisme}

Ondanks onderlinge verschillen zijn realisme en perspectivisme in éen opzicht aan elkaar verwant. Zowel de realist als de perspectivist twijfelen er niet aan dat we buiten alle wetenschappelijke ontwikkelingen om een onderscheid kunnen aanbrengen tussen onze ideeën over de realiteit en hoe die realiteit er werkelijk uitziet. Aan de ene kant is er het niveau van het kennend subject, het niveau van de theorieern of, moderner geformuleerd, de conceptuele systemen die wetenschapsbeoefenaren naar voren brengen. Aan de andere kant is er het niveau van de gekende objecten, van de werkelijkheid zoals die buiten ons denken bestaat. Uitgaande van deze dualiteit ligt het voor de hand kennis- 
verwerving te omschrijven in termen van de ruimtelijke en zintuiglijke metaforen die realisten zowel als perspectivisten naar voren brengen. In beide gevallen prevaleert wat de pragmatistische filosoof John Dewey de 'spectator conception of knowledge' heeft genoemd: de ideale wetenschapsbeoefenaar is bovenal een toeschouwer, lemand die de dingen van een afstand waameemt. Theorieen worden in dit verband snel opgevat als brillen of oogkleppen: zij scherpen de blik of maken wetenschappers juist blind.

In het begin van deze eeuw hebben John Dewey en andere pragmatisten de beperkingen van deze kennisconceptie reeds helder uiteengezet. ${ }^{33}$ Kennis komt niet tot stand door onze geest of de wereld in ogenschouw te nemen, maar is een produkt dat in actieve omgang met de wereld verworven moet worden. Wetenschap is een vorm van handelen waarin tegelijk met onze kennis ook het object van die kennis aan een voortdurende reconstructie onderworpen wordt. Deze pragmatistische opvattingen hebben in het genre van de disciplinegeschiedenis echter maar weinig sporen nagelaten. ${ }^{34} \mathrm{Met}$ enige hardnekkigheid wordt daarin vastgehouden aan het idee van de wetenschapper als waarnemer, een instelling die door twee omstandigheden in de hand wordt gewerkt. Allereerst lijkt het pragmatistische wetenschapsconcept door haar handelingsmetaforen van constructie en reconstructie in te druisen tegen het standaardbeeld van wetenschap en de idealen die daarmee verbonden zijn, zoals het tonen van deemoed voor de feiten en het betrachten van objectiviteit. Maar belangrijker voor het standhouden van de 'spectator conception of knowledge" is misschien dat deze conceptie door finalistische geschiedschrijving alsnog waar' kan worden gemaakt. Vooral wanneer we hedendaagse onderscheidingen tussen de realiteit en de kennis daarvan of tussen de maatschappij en allerlei theorieen daarover terugprojecteren op de wetenschapsgeschiedenis, ontstaat snel de indruk dat zich alleen op het niveau van het kennend subject veranderingen hebben voorgedaan: alhoewel er in de loop der tijd nieuwe meningen, theorieen en perspectieven zijn ontstaan, verwijzen zij toch steeds naar dezelfde wereld of naar dezelfde problemen in die wereld. ${ }^{35}$

\section{Nieuwe versies van de wereld}

Wetenschappelijke vitspraken verwijzen altijd naar de wereld buiten ons. Maar is dat inderdaad altijd dezelfde realiteit? De finalistische historicus, geleid door realistische of perspectivistische opvattingen over de aard van wetenschappelijke kennis, beantwoordt die vraag bij voorbaat bevestigend. Daarmee wordt echter over een aantal problemen van historische tekstinterpretatie heen gestapt.

Noch afzonderlijke uitspraken noch gehele teksten warin een aanspraak op waarheid ligt vervat, spiegelen datgene waarnaar ze verwijzen, al proberen ze gewoonlijk wel die indruk te wekken. Wetenschappelijk werk heeft wat dat betreft veel weg van realistische schilderkunst. Schilderijen uit dat genre suggereren iets getrouw af te beelden, maar slagen daarin alleen door de toepassing van allerlei stilistische technieken. De suggestie dat zulke schilderijen een deel van de werkelijkheid spiegelen, is dan ook een effect van die technieken. ${ }^{36}$ Teksten kunnen op een soortgelijke manier een realistische indruk wekken, zij het vooral met retorische technieken. ${ }^{37}$ De realiteit die in teksten onder woorden wordt gebracht, hoeft dan ook niet altijd een en dezelfde te zijn; sommige teksten hebben juist de ambitie een nieuwe realiteit te creëren of uit te beelden. Het eerder aangehaalde jeugdwerk van Auguste Comte illustreert zo"n poging. Comte werpt 
daarin namelijk niet alleen een nieuw licht op de toenmalige sociale werkelijkheid - hij wil tevens (en vooral) aangeven wat onder de sociale realiteit moet worden verstaan. ${ }^{38}$ Daartoe benut hij een retorische techniek die door Perelman en Olbrechts-Tyteca de ontkoppeling van concepten is genoemd. ${ }^{39}$ Deze ontkoppelling betreft hier vooral de concepten 'waarneming' en 'inbeelding'.

Comte verdiept in de tekst allereerst de kloof tussen beide begrippen: het stuk staat los van de spelers, om zijn eigen metafoor te gebruiken. Waarneembaar is de wetmatige ontwikkeling van de civilisatie; op dat niveau liggen de 'reele' feiten van het menselijk samenleven. Wie zich niets 'inbeeldt' houdt het stuk en niet haar spelers voor de realiteit. In het verlengde van het aanbrengen van deze kloof herschikt Comte vervolgens de orde der feiten. Wat voorgangers of opponenten voor fundamentele feiten houden, zijn slechts 'abstracties' of de gevolgen van volgens Comte meer reële feitten. Bij deze herschikking van de orde der feiten kan Comte het echter niet laten. Hij dient tenslotte nog aan te geven hoe 'inbeelding" terzijde kan worden geschoven, opdat de door hem opgevoerde reële feiten ook daadwerkelijk kunnen worden 'waargenomen". 'Comment", vraagt hij zich dan ook af, 'discerner les réalites qui font si peu de bruit, au milieu des fantômes qui s'agitent sur la scène?'40 Oftewel: hoe ontdekken we achter de rondrennende acteurs nog het stuk? De oplossing is bekend: daartoe zijn we alleen in staat wanneer we ons laten leiden door de 'positieve' methode. In de besproken tekst doet Comte kortom drie dingen tegelijk: hij bepaalt wat telt als (fundamenteel) feit, hij wijst deze feiten aan en deelt tenslotte mee op welke manier die aangewezen feiten kunnen worden waargenomen.

Intellectuelen als Comte bieden ons niet zozeer een nieuwe theorie over de politiek of de maatschappij, als wel een nieuwe versie van de (sociale) wereld. Dat wil zeggen: zij proberen een manier van spreken te introduceren waarbinnen begrippen als politiek en maatschappij een nieuwe inhoud krijgen, een manier van spreken waarin 'de samenleving' geen idee of theoretisch begrip is, maar een te observeren realiteil, een object waarnaar men kan verwijzen en waarover men 'feitelijke' uitspraken kan doen. Pogingen als van Comte de wetenschap te vernieuwen, houden met andere woorden ook een conceptuele reconstructie van de werkelijkheid in: de samenleving lag niet cenvoudig klaar om te worden ontđekt, ze moest tot een waar te nemen realiteit worden gemaakt. 41

Door te zeggen dat Comte in zijn teksten een nieuwe versie van de wereld naar voren probeert te brengen, kan een anachronistische interpretatie van zijn werk voorkomen worden. Maar deze spreekwijze biedt de historicus meer voordelen. Om te beginnen zijn we zo beter in staat de rivaliteit tussen disciplines te begrijpen. Wanneer het handelen van wetenschappers en intellectuelen gericht is op het maken of uitbouwen van nieuwe versies van de wereld, dan is het immers geenszins zeker dat deze naadlloos bij andere versies van de wereld zullen aansluiten, zoals het legpuzzel- en het loketmodel van disciplines suggereren. ${ }^{42}$ De wetenschap van de politick die Comte vorm en inhoud geeft, kan zich in elk geval niet vestigen op een nog onbezette zetel. Ze heeft zelfs nadrukkelijk de intentie andere wetenschappen - zoals de geschiedwetenschap - een stapje terug te laten doen. Comte creěert in de tekst immers een nieuw, fundamenteler realiteitsniveau waarvan beweerd wordt dat alleen zijn wetenschap van de politiek er toegang tot heeft. 
Brengen we wetenschapsontwikkeling in verband met het maken van nieuwe versies van de wereld, dan wordt het bovendien mogelijk meer oog te krijgen voor de cultuurpolitieke inzet van allerlei geredetwist over de legitimiteit van een discipline. Wanneer Comte er aanspraak op maakt cen nieuw realiteitsniveau aan te boren, dan gaat het hem er niet alleen om intellectueel aanzien te verwerven. In het verlengde daarvan eist Comte voor zijn wetenschap van de politiek ook een culturele rol op. Als geen andere zou deze nieuwe wetenschap de hervorming van de Franse samenleving in goede banen kunnen leiden. Deze dubbele aanspraak treffen we niet alleen bij Comte aan. Discussies over de werkelijke aard van de sociale realiteit en over de wijze waarop die realiteit ontsloten kan worden, hebben naast een theoretisch aspect ook altijd een culturpolitieke lading. ${ }^{43}$ Hoe meer sociologen er in slagen hun definities van de realiteit te presenteren als geldig en waar, en hoe meer relevante buitenstaanders zoals politici, beleidsmakers en intellectuelen in sociologische termen over de (sociale) wereld gaan spreken, hoe dominanter de culturele rol van de sociologie en hoe hoger de status van deze discipline zal zijn. Van de andere kant spreekt ook de econoom die zich over de sociologie laatdunkend uitlaat, niet alleen een wetenschappelijk oordeel uit; hij geeft er tevens mee aan dat de sociologie in vergelijking met zijn eigen vak slechts een culturele bijrol kan vervullen. En als Graham Greene in Getring to Know the General de sociologie omschrijft als een wetenschap die teert op banaliteiten en abstract jargon, dan is dat meer dan obscurantistisch gemopper. Greene en vele literatoren met hem wensen niet alleen verstrooiing te bieden, maar maken er ook aanspraak op ons een beeld van de menselijke conditie te verschaffen. Op grond daarvan willen zij niet dat de sociale wereld een sociologisch karakter krijgt, omdat in zo'n wereld, naar zij vrezen, hun eigen culturele rol zal worden ingeperkt. De strijd om intellectuele status of wetenschappelijke legitimiteit is kortom ook altijd een strijd om culturele autoriteit.

De traditionele disciplinegeschiedenis van de sociologie presenteert de maatschappij gewoonlijk als een soort natuurverschijnsel dat pas in de $19 \mathrm{e}$ eeuw werd opgemerkt en waarvan de bestudering, nadat eenmaal aan bepaalde intellectuele en sociale voorwaarden was voldaan, min of meer vanzelfsprekend tot de vorming van een aparte discipline heeft geleid. Deze voorstelling van zaken is in dit hoofdstuk in een aantal stappen ter discussie gesteld. Aan de hand van enkele voorbeelden heb ik laten zien hoe finalistische geschiedschrijving, zeker wanneer ze uitgaat van het legpuzzel- en/of het loketmodel van disciplines, de identiteit een discipline niet tot onderwerp van onderzoek maakt, maar haar bij voorbaat veronderstelt. Vragen als hoe de sociologie zich een eigen identiteit heeft verworven en hoe deze in de loop van de $19 \mathrm{e}$ en $20 \mathrm{e}$ eeuw is veranderd, schuiven zo naar de achtergrond. Een en ander heeft tot gevolg dat ook historische continuiteit niet zozeer wordt onderzocht, alswel door de historicus vanuit het heden wordt aangebracht.

Deze conclusies bleken te kunnen worden aangevuld door naast de geschiedenis van disciplines ook hun status in de bespreking te betrekken. Wie de identiteit van een discipline niet problematiseert, wordt er eveneens snel toe verleid haar bij voorbaat een wetenschappelijke legitimiteit toe te kennen, in plaats van zich de vraag te stellen hoe de leden van een discipline die legitimiteit binnen bepaalde contexten en praktijken verwerven. Ook wanneer men ten opzichte van de identiteit van de eigen discipline een 
meer reflexieve houding inneemt, maar desalniettemin vasthoudt aan een realistische of perspectivistische kennistheorie, is er voor het stellen van die vraag weinig aanleiding. En gaat men voorbij aan het probleem hoe een nieuwe wetenschap zich een legitieme plaats verovert op het academische toneel, dan blijft tevens de inzet van intellectuele rivaliteit onduidelijk. Bijgevolg blijft de vraag onaangeroerd hoe, in ons geval, de sociologie zich ten opzichte van andere disciplines culturele autoriteit heeft proberen te verwerven.

De vragen die in het genre van de disciplinegeschiedenis zo naar de achtergrond zijn geschoven, staan in dit boek juist op de voorgrond. Deze studie naar de identiteit van de vroege Amerikaanse en Duitse sociologie is tegelijkertijd een onderzoek naar de met de geschiedenis en de status van deze discipline verbonden problemen van continuitteit, legitimiteit en autoriteit. 
Noten behorend bij hoofdstuk 1

1. Zie voor meer gedetailleerde informatie over het ontstaan van het moderne systeem van wetenschappelijke disciplines: Ellwein (1985), Guntau/Laitho (1987), Jahnke/Otte (1981), Stichweh (1984), Wittrock (1985).

2. Een overzicht van de geschiedenis van de classificatie van wetenschappen biedt Speziali (1973/1974); vgl. ook Lepenies (1976) en de gevalstudies in Ellen/Reason (1979).

3. Voor een overzicht van de $19 \mathrm{e}$-eeuwse discussies over de classificatie van wetenschappen zie Dolby (1979). Een goede indicator voor de dalende interesse in zulke classificeringen is de veranderende functie die encyclopedieën in de loop van de $19 \mathrm{e}$ ceuw krijgen. Ze verliezen hun betekenis als filosofisch of politiek manifest en worden wat ze tegenwoordig nog altijd zijn: nuttige naslagwerken. Vgl. Yeo (1991).

4. Of hun de wet ook inderdaad niet meer wordt voorgeschreven, is natuurlijk een andere vraag. Wel moet worden bedacht dat het verwerven van disciplinaire soevereniteit niet inhoudt dat de relaties tussen een wetenschap en haar omgeving verbroken worden; het betekent veeleer dat deze relaties anders worden gedefinieerd. Vgl. Wagner/Wittrock (1991).

5. Deze vergelijking ontleen ik aan Elias (1982a).

6. Zie hiervoor Pott (1992).

7. Het hier gemaakte onderscheid tussen legpuzzel- en loketmodel van disciplines is verwant aan het scholastieke onderscheid tussen 'materieel' en 'formeel' object van een wetenschap. Veel moderne handboeken maken nog altijd gebruik van dit onderscheid om een vakgebied te definiëren.

8. Van Doorn/Lammers, 9e druk (1968): 23 en 24.

9. In de $18 \mathrm{e}$ eeuw bestaat er nog een nauwe band tussen de wereld van de objecten en de wereld van de naturwetenschap. Zo stoelt de toen gangbare indeling van de natururwetenschappen in zoologie, botanie en mineralogie op het onderscheid tussen drie 'rijken': het dierenrijk, het plantenrijk en het rijk van de mineralen. Binnen dit classificatiesysteem is echter de plaats van de (moderne) fysica en chemie moeilijk te bepalen: ze hebben eigenlijk geen eigen object. Met de vestiging van deze nieuwe wetenschappen als zelfstandige disciplines verandert dan ook het traditionele classificatiesysteem. Zie voor dit transformatieproces Stichweh (1984). Dat onderscheidingen tussen disciplines niet worden ontdekt maar gemaakt, is de boodschap van veel wetenschapshistorisch onderzoek dat in de jaren zeventig en tachtig is verricht. Zie b.v. Elias/Martins/Whitley (1982), Mendelsohn/Wiengart/Whitley (1977) en Shapin/Schaffer (1985).

10. Zie b.v. Parsons (1965a).

11. Zie Wittgenstein (1958): par. 66-71.

12. Vgl. Rorty (1991).

13. Zie voor deze wending Boon/De Vries (1989), Shapin (1982), Shuster/Yeo (1986), De Vries (1982). Goede Nederlandse voorbeelden van dit type wetenschapsonderzoek zijn Dehue (1990), Harbers (1986), Koenis (1991).

14. Comte (1822).

15. Over de functie en het gebruik van disciplinegeschiedenis zie Graham/Lepenies/ Weingart (1983).

16. Collins/Makowsky (1974): 11/23.

17. Zo schrijft de Duitse socioloog Norbert Elias in zijn boek Wat is sociologie? over Comte: "Hij had waanideeẻn - zoals dat alle wezenlijke dingen drieledig zijn - en was ook een beetje gek. Maar wanneer men zich, afgezien van alle grillen en excentriciteiten de moeite neemt om hier en daar het stof weg te blazen, dan komt men in het werk van Comte ideeên tegen die zo goed als nieuw zijn. (...) Vaak wordt alleen maar vermeld dat 
Comte de naam "sociologie" voor de nieuwe wetenschap uitvond. Maar hij vond een nieuwe naam uit, juist omdat hij inzag dat de wetenschap van de maatschappij een nieuwe vorm van wetenschap is, die zich niet laat onderbrengen bill de eerder ontwikkelde fysica of biologie'. Elias (1971): 36/40.

18. Het woord legende heeft verschillende betekenissen, zoals 'een levensbeschrijving van een heilige', 'een niet op historische gronden maar op volksoverlevering berustend verhaal' en 'een ongeloofwaardig verhaal', Rechtlijnige vooruitgangsverhalen over een discipline kunnen in al deze betekenissen legendes' worden genoemd: wetenschappers gaan in zulke verhalen een beetje op heiligen lijken; het zijn bij witstek verhalen die door de leden van een discipline aan elkaar worden doorverteld; ze worden lang geloofd maar op een dag ongeloofwaardig gevonden.

19. Dit aanbrengen van continuilteit hoeft niet te betekenen dat de auteurs van handboeken geen oog hebben voor fasen in de ontwikkeling van de discipline. Periodisering in termen van voorgeschiedenis, vestiging van de discipline - de periode van de 'founding fathers' - en verdere uitbouw van het vak, treft men in bijna alle disciplinegeschiedenissen aan. Over de relatie tussen disciplinegeschiedenis en de behandeling van historische continuilteit zie De Wilde/De Vries (1987).

20. Het traditionele genre van de disciplinegeschiedenis wordt vaak 'presentistisch' of 'whiggish' genoemd. Deze aanduidingen hebben echter veel misverstanden opgeroepen, vooral omdat ze geheel en al lijken te verwijzen naar het standpunt dat de historicus ten opzichte van het verleden inneemt. De presentist of de Whig-historicus wordt in dat geval verweten het verleden vanuit het heden te beoordelen. De repliek op dit verwijt luidt onder meer dat het voor geen enkele historicus mogelijk is om bij zijn onderzoek het verdere verloop van de geschiedenis buiten beschouwing te laten, alleen al omdat juist vanuit latere ontwikkelingen eerdere gebeurtenissen pas zin en betekenis krijgen. Toch raakt dit verweer niet wezenlijk de kritiek die op het genre van de disciplinegeschiedenis is geuit. De kwestie is niet dat historici niet vanuit het heden mogen terug kijken op de ontwikkeling van een vakgebied, het gat er om hoe dat gebeurt. Daarom is 'finalistisch' een betere benaming voor het genoemde genre: deze term zegt niet lets over het standpunt van historici, maar typeert de opbouw en structuur van hun verhalen. Zie voor de discussie over het nut en nadeel van anti-presentistische wetenschapsgeschiedenis Boon (1989), Harrison (1987), Mayr (1990) en Seidman/Merton/Jones (1985).

21. Van Houten in: Rademaker (red.) (1978): 616.

22. Vgl. het Nawoord in Kossman (1986). Deze veronderstelling stoelt vaak op een naïef-realistische opvatting van historische feiten in het algemeen. Voor een kritiek op deze opvatting zie De Rijk (1979).

23. Een aardige 'empirische' weerlegging van de veronderstelling dat het sociologische project sinds het eind van de $19 \mathrm{e}$ eeuw onveranderd is gebleven, geeft Kinloch (1984). Hij analyseerde 105 inleidingen in de sociologie, geschreven tussen 1894 en 1981. In de manier waarop het vak in die boeken wordt gedefinieerd treden in de loop der tijd allerlei veranderingen op. Van een evolutionair georienteerde etnografie is het een wetenschap geworden die een breed spectrum van sociaal-politieke vraagstukken bestudeert.

24. Laeyendecker (1981): 12.

25. Ibid.: 55.

26. Geciteerd in Lepenies (1985): 76.

27. Greene (1984): 91.

28. W. Hessel in Bril e.a. (1966): 55.

29. Zie b.v. Gouldner (1970), Hawthorne (1976), Van Houten (1970).

30. Deze opvatting wordt ondermeer verdedigd in Elias (1982b). Alhoewel deze socioloog het legpuzzelmodel van disciplines uitdrukkelijk afwijst in Elias (1982a), neemt hij in andere publikaties weinig afstand van de realistische kennistheorie die achter dit model schuil gaat. 
31. Karl Mannheim is cen belangrijk stamvader van dit type perspectivisme. In Ideologie und Utopie (1929) vat hij alle tradities in het sociaal-politieke denken op als ideologieen. Het begrip ideologie heeft voor Mannheim dan ook een andere betekenis dan Marx daaraan gaf. In Mannheims visie vertekent een ideologie niet zozeer de werkelijkheid, maar houdt ze veeleer een aspect van die werkelijkheid voor het geheel. Volgens Mannheim leveren ideologieen dus geen onware maar eenzijdige kennis. Dit perspectivisme moet onderscheiden worden van het kennistheoretische pluralisme dat b.v. Kuhn en veel (hedendaagse) pragmatisten verdedigen. Terwijl de pluralist niet uitgaat van een meta-orde waarbinnen de verschillende perspectieven kunnen worden gesitueerd en op hun mate van 'eenzijdigheid' kunnen worden beoordeeld, begrijpt de perspectivist standpunten wel binnen de context van zo'n (hem bekende) orde. Zie voor een bespreking van Mannheims perspectivisme De Wilde (1984). Het perspectivisme wordt verdedigd door ondermeer Kobben (1991), Lorenz (1987), Nolte (1973), Zijderveld (1974).

32. De optische metafoor ontleent haar aantrekkingskracht niet alleen aan het feit dat ze het relativisme op een afstand houdt. Met name binnen de menswetenschappen biedt ze een legitimatie voor het naast elkaar bestaan van meerdere meta-theoretische stromingen. Nemen we de optische metafoor immers letterlijk, dan behoeven we conceptuele pluriformiteit geen zorgwekkend verschijnsel te vinden. Het tegendeel is in dat geval eerder waar: hoe meer perspectieven, hoe vollediger de wereld in beeld komt.

33. Zie b.v. Dewey, 1920 (1957), Dewey, 1929 (1960), Mead (1938). Over het verschil tussen perspectivisme en pragmatisme zie De Wilde (1987b).

34. Een uitzondering vormt Schuyt (1986). Over de vraag of deze studie wel pragmatistisch genoeg is, zie De Vries (1988) en Schuyts repliek in Schuyt (1988).

35. Zo ondergaat bij Van Houten 'de maatschappij' sinds haar ontdekking geen ontologische veranderingen meer en nemen bij Laeyendecker sociologische problemen een eeuwigdurend karakter aan. Zie voor een kritiek op dit soort 'perennialism' in de ideeengeschiedenis Skinner (1969), ook opgenomen in Tully (1988).

36. Vgl. Gombrich (1960).

37. Vgl. Ankersmit e.a. (1990), Nash (1990).

38. De analyse van Comtes tekst staat hier in het teken van het systematische probleem wat een niet-finalistische lezing van historische teksten eigenlijk inhoudt. Historische vragen als 'is Comte inderdaad een belangrijk grondlegger van de sociologie' en 'inhoeverre treedt Comte in zijn jeugdwerk in de voetsporen van Saint-Simon' blijven hier buiten beschouwing. Zie daarvoor o.a. Heilbron (1990) en Lepenies (1974).

39. Perelman/Olbrechts-Tyteca (1971): 411 e.v.

40. Comte (1822): 283.

41. Zie voor dit argument Tenbruck (1981) en White (1978). Vgl. ook Ankersmit (1990).

42. Dit argument ontleen ik aan Goodman (1978).

43. $\mathrm{Vgl}_{\text {. }}$ Bourdieu (1981), Pels (1986), Rouse (1987). 
II

WETENSCHAP ALS MORAAL

\author{
Over wat in de Verenigde Staten aan de vestiging \\ van de sociologie voorafging
}

\title{
1. Het relatieve succes van de Amerikaanse sociologie
}

In de Verenigde Staten is het beroep van socioloog bijna een eeuw oud. In de jaren negentig van de $19 \mathrm{e}$ eeuw worden de eerste hoogleraren in de sociologie benoemd, de eerste leerboeken gedrukt en het eerste sociologisch tijdschrift uitgebracht; de eerste studenten in het nieuwe vak studeren nog voor de eeuwwisseling af. In Duitsland en Engeland daarentegen worden de eerste hoogleraren in de sociologie niet voor de eerste wereldoorlog aangesteld. Net als in Italië, Oostenrijk en Nederland krijgt de sociologie daar pas in de loop van de $20 \mathrm{e}$ eeuw de gestalte van zelfstandig vakgebied. In Frankrijk presenteert Durkheim de sociologie in de $19 \mathrm{e}$ eeuw al wel als een aparte discipline, maar het zal tot 1958 duren voordat de sociologie binnen het Franse universitaire systeem als hoofdvak wordt erkend. ${ }^{1}$ In vergelijking met Europa heeft in de Verenigde Staten de sociologie zich als academische discipline dus betrekkelijk vroeg gevestigd.

In de Verenigde Staten slaat de sociologie ook snel haar vleugels uit. De in 1905 opgerichte professionele vereniging heeft al gauw meer dan honderd leden; in $1909 \mathrm{kent}$ het land reeds vijftig hoogleraren in het nieuwe vak en op bijna vierhonderd univer* siteiten en 'colleges' worden cursussen in de sociologie gegeven. ${ }^{2}$ In geen ander land heeft dit vak zich in een dergelijk vlot tempo weten te ontwikkelen. Varwaar die betrekkelijk vroege en snelle opmars van de Amerikaanse sociologie?

Vaak wordt verwezen naar het karakter van de toenmalige Amerikaanse samenleving. 'Het was', schrijft Laeyendecker, "een beweeglijke, snel veranderende samenleving, waarin sociale problemen niet konden uitblijven. Daardoor werd de sociologiebeoefening sterk gestimuleerd."3 Hinkle en Hinkle geven een soortgelijk antwoord in hun klassieke studie naar de ontwikkeling van de Amerikaanse sociologie. Het vak is ontstaan als een antwoord op de vele nieuwe vragen die werden opgeroepen door de snelle industria lisering en urbanisering van de Amerikaanse samenleving na de Burgeroorlog, betogen ze. $^{4}$

De Duitse socioloog Dahrendorf heeft geprobeerd de verklaring van Hinkle en Hinkle te verbeteren. Ook in Engeland, zo kan men immers tegenwerpen, was sprake van een snelle industrialisering en urbanisering. Toch wist de sociologie zich daar als academische discipline pas betrekkelijk laat te vestigen. Dahrendorf merkt nu op dat niet zozeer de snelle industrialisatie en verstedelijking een typisch Amerikaans verschijnsel is. Een ander kenmerk van deze samenleving is in vergelijking met Europese landen 
uitzonderlijker: haar mobiele en multiraciale karakter. En juist die kenmerken kunnen volgens hem de vroege opkomst en de snelle ontwikkeling van de Amerikaanse sociollogie verklaren. Want: Menschen, die in ihrem eigenen Land immer wieder Fremde werden oder zumindest eìnmal Fremde waren, haben einen schărferen Blick für "soziale Tatsachen" als die, die fraglos in ererbten Bindungen leben."

Auteurs als Dahrendorf en Hinkle c.s, vergelijken de opkomst van de sociologie in de Verenigde Staten met de vestiging ervan in Europa. Gegeven die vergelijking zijn aanduidingen als 'vroeg' en 'snel' inderdaad op hun plaats. Richten we ons daarentegen alleen op de Verenigde Staten zelf, dan ontstaat een ander beeld.

In de jaren zeventig en tachtig van de $19 \mathrm{e}$ eeuw komt in de Verenigde Staten het proces van professionalisering in een stroomversnelling terecht. Medische specialisten organiseren zich, juristen stichten de 'American Bar Association' en reeds bestaande professionele verenigingen maken een begin met het opstellen van beroepscodes. In een periode van twintig jaar zien bijna tweehonderd nieuwe beroepsorganisaties het levenslicht. ${ }^{6}$ Deze professionaliseringsgolf raakt niet alleen 'intellectuele' beroepen. Honkbal, bij voorbeeld, ontwikkelt zich tot een professioneel beoefende sport. Honkbaltijdschriften beginnen te verschijnen en er komen leerboeken beschikbaar als The Game of Baseball: How to learn it, how to play it, and how to teach it.

Vanaf het eind van de jaren zeventig krijgen ook de menswetenschappen een meer professioneel aanzien. Uitgaande van het moment waarop beroepsverenigingen ontstaan, lopen de geschiedwetenschap en de economie voorop, gevolgd door de psychologie, de antropologie en de politieke wetenschap. Historici organiseren zich in 1884, economen een jaar later. In 1892 wordt de 'American Psychological Association' opgericht, in 1902 de "American Anthropological Society" en in 1903 de "American Pollitical Science Association'. Sociologen sluiten de rij; zij organiseren zich pas in 1905. Andere tekenen van professionalisering, zoals bij voorbeeld het verschijnen van tijdschriften en leerboeken, wijzen op eenzelfde opeenvolging in de tijd. Vergeleken met andere disciplines en professies in de Verenigde Staten vestigt de sociologie zich dus niet vroeg, maar rijkelijk laat.

Gemeten naar binnenlandse verhoudingen verdient ook het oordeel dat de sociologie zich in de Verenigde Staten snel ontwikkelt, enige relativering. Disciplines als de geschiedwetenschap, de economie en de psychologie doen het naar verhouding beter: ze verkrijgen sneller een respectabel aanzien en trekken ook meer studenten en onderzoeksgelden aan. In de laatste decennia van de $19 \mathrm{e}$ eeuw wordt het mogelijk op de universiteit van Harvard een graad in deze vakken te verwerven, maar sociologie kan men er vóor 1927 niet studeren. $^{7}$

ledere socioloog zal beamen dat de geschiedschrijving van zijn discipline een 'contextualistisch' karakter dient te hebben. Maar welke context kiezen we? De verteller van een 'vroeg en snel' verhaal over de opkomst van de Amerikaanse sociologie kiest immers een andere context dan de verteller van een 'laat en traag' verhaal. Alvorens in de tijd terug te gaan, zijn enkele historiografische opmerkingen op hun plaats.

\section{Drie legendes}

In de genoemde 'vroeg en snel' verhalen wordt een direct verband gelegd tussen de wijze waarop in de Verenigde Staten de sociologie, als wetenschap van de maatschappij, 
gestalte krijgt en het 'karakter' van die maatschappij zelf. Deze verklaringsstrategie heeft echter een aantal nadelen.

Om te beginnen neemt ze onvoldoende afstand van de legende van de intieme relatie tussen sociologie en maatschappij. Sociologen zeggen vaak van hun vak dat het de maatschappij een spiegel voorhoudt, dat het de diffuse culturele en sociale tendenzen die in een samenleving werkzaam zijn, zichtbaar maakt. Toch is het niet verstandig dit zelfbeeld tot leidraad van historisch onderzoek te maken.

Beroepsgroepen creëren altijd een beeld van zichzelf, weet elke socioloog. Tevens is hij of zij zich er scherp van bewust dat de wijze waarop een groep zichzelf presenteert, gewoonlijk geen betrouwbare indicator is voor het daadwerkelijke handelen van die groep. Dat dit sociologische inzicht ook geldt voor de sociologie zelf, is evenwel in de disciplinegeschiedenis van het vak lange tijd niet verdisconteerd. Vooral verhalen die op het eerste gezicht zeer sociologisch lijken, doordat daarin de ontwikkeling van de sociologie nauw verbonden wordt met de ontwikkeling van de moderne samenleving, zijn in dit opzicht juist niet sociologisch genoeg. Daarin wordt de geschiedenis vaak zo gemodelleerd dat het lijkt alsof sociologen steeds de woordvoerders van 'de maatschappij zijn geweest. Die indruk kan op twee manieren worden gewekt. Allereerst door de context waarin men het vak situeert met behulp van sociologische termen te typeren. Zo krijgt die context dadelijk al sociologische eigenschappen. Die constructie kan, ten tweede, door een mechanisme van uitsluiting worden versterkt. Naast sociologen hebben ook altijd andere groepen - journalisten, historici, juristen, literatoren - geprobeerd het 'karakter' van hun tijd onder woorden te brengen en hun berichten stemmen zeker niet altijd overeen met de sociologische verslaggeving. Zulke alternatieve beschrijvingen van de maatschappelijke context weert de geschiedschrijwer van de sociologie gewoonlijk uít zijn verhaal. Daarin staat hij uiteraard niet alleen. Wie een geschiedenis van de Amerikaanse journalistiek, van de Amerikaanse psychologie of van de Amerikaanse letterkunde erop nașlaat, zal merken dat de 'maatschappelijke context' die in zulke verhalen wordt opgevoerd, steeds opmerkelijk nauw bij de ontwikkeling van de betreffende discipline aansluit."

Modelleren we de context te sterk naar de groep waarvan we de geschiedenis schrijven, dan zijn we tevens onvoldoende in staat afstand te nemen van de legende van het primaat van de behoefte. Het is, alweer, een bekend sociologisch inzicht dat het behoeftepatroon van mensen niet los staat van institutionele veranderingen in cen samenleving. De beroepensociologie leert bij voorbeeld dat de behoefte aan psychische hulpverlening tegelijkertijd ontstaat met de opkomst van de institutie die we psychotherapie noemen. Het verklaren van het ontstaan van zulke instituties vanuit een daaraan voorafgaande behoefte, wordt door sociologen dan ook meestal afgewezen. Toch zien we ook in dit geval dat voor de eigen discipline valk een uitzondering wordt gemaakt. In de sociologische disciplinegeschiedenis wordt bij herhaling de opkomst van de sociologie in de $19 \mathrm{e}$ eeuw verklaard vanuit een behoefte aan sociologie. In die tijd, zo wordt dan betoogd, raakt de samenleving op drift, verscherpen de sociale conflicten zich en wordt de 'sociale kwestie' een steeds nijpender probleem. Al deze omstandigheden, zo vervolgt men, doen de behoefte aan sociologie duidelijk toenemen. Juist in het licht van hedendaagse sociologische inzichten is deze manier van redeneren echter een vorm van 'begging the question'. Want wie zo redeneent neemt impliciet aan dat de 19e-eeuwse 
mens zijn problemen reeds in sociologische termen benoemt.

De beide genoemde legenden versterken op hun beurt het geloof in een derde: de legende van het lege toneel. In de geschiedenissen die auteurs als Dahrendorf en Hinkle c.s. vertellen, worden intellectuele discussies buiten de sociologie wel ter sprake gebracht, maar spelen ze in hun betoog slechts een passieve rol. Ontwikkelingen in bij voorbeeld de biologie, de literatuur of het sociale denken in het algemeen figureren louter als achtergrond; ze vormen het decor waarin sociologen als enige acteurs voor het voetlicht treden. Door aldus alle aandacht te vestigen op het optreden van deze ene groep wordt gauw de indruk gewekt dat sociologen als eersten een nog maagdelijk terrein van onderzoek en discussie bezoeken, een gebied dat voor hun opkomst niet reeds door andere groepen geheel of gedeeltelijk is bezet. Elementen van rivaliteit worden buiten het verhaal gehouden waardoor de vestiging van de sociologie inderdaad iets vanzelfsprekends krijgt. ${ }^{10}$

Deze historiografische opmerkingen hebben methodologische consequenties. Het scala van ideeen en praktijken, dat we de geschiedenïs van de sociologie noemen, is in verschillende westerse landen tot ontwikkeling gekomen. Die ontwikkeling is niet steeds op dezelfde manier in gang gezet en ze is ook niet steeds langs dezelfde route verlopen. Het is daarom zeker zinvol de geschiedenis van de vroege Amerikaanse sociologie te vergelijken met de opkomst van de sociologische discipline in andere landen. Onmiddellijk zo'n vergelijkend standpunt innemen, betekent echter al gauw dat de lokale context waarbinnen de sociologie gestalte krijgt hooguit een voorwaardenscheppende functie wordt toegekend, een bezwaar dat we nu ook anders kunnen formuleren: de opkomst van de sociologie in Duitsland of de Verenigde Staten direct verbinden met het 'karakter' van de betreffende samenlevingen resulteert snel in een verhaall dat te weinig afstand neemt van de drie besproken legendes.

Het Amerikaanse intellectuele toneel was niet leeg. Geruime tijd voordat de sociologie zich in de Verenigde Staten aandiende als 'de wetenschap van de maatschappij", bestond er al zo'n wetenschap. Ze werd alleen niet sociologie genoemd, maar Sociale Wetenschap. "De beoefenaren van deze 'social science' waren verenigd in de in 1867 opgerichte American Social Science Association. De oprichters van deze vereniging stond een ander type maatschappijwetenschap voor ogen dan de latere academische sociologen.

Naast deze Sociale Wetenschap kende de academische sociologie nog een tweede voorloper': de zogenoemde synthetische filosofie van de Brit Herbert Spencer. Spencers werk is voor de eerste generatie van academische sociologen in Amerika van veel betekenis geweest. $\mathrm{Zij}$ gingen er echter heel anders mee om dan Spencers eerste Amerikaanse discipelen. Deze spencerianen zetten zich af tegen Sociale Wetenschap, net als de latere sociologen doen. Maar evenals Spencer zelf verzetten zij zich tegen de vorming van een aparte sociologische discipline. Op het einde van de $19 \mathrm{e}$ eeuw legden beide groeperingen het echter af tegen de pleitbezorgers van een discipliniare wetenschapsstructuur.

De vestiging van de Amerikaanse sociologie als academische discipline bespreek ik in het volgende hoofdstuk. Hieraan vooraf besteed ik in dit hoofdstuk aandacht aan de twee genoemde vormen van pre-disciplinaire wetenschapsbeoefening en aan de opkomst van een disciplinair georganiseerd wetenschapsbedrijf in de Verenigde Staten. Dat doe ik 
niet alleen om uit de ban van de genoemde drie legendes te blijven, maar ook om duidelijk te maken dat Sociale Wetenschap, Spencers filosofie en de academísche sociologie niet dezelfde identiteit bezitten.

\section{Sociale Wetenschap: een pre-disciplinaire wetenschap van de samen- leving}

Op 4 oktober 1865, enkele maanden na de beëindiging van de Burgeroorlog, wordt in het State House in Boston de American Social Science Association (ASSA) opgericht. Bijna honderd mannen van aanzien bezoeken deze oprichtingsvergadering. Onder hen bevinden zich professoren, politici, publicisten en een enkele ondernemer. Het zijn allen Republikeinen, geestverwanten van de in dat voorjaar vermoorde president Lincoln. Ze delen vooral Lincolns optimisme. Nu de strijd tegen de slavernij gewonnen is, moet het mogelijk zijn ook andere maatschappelijke misstanden voor eens en voor altijd uit de (Amerikaanse) wereld te helpen. In de uitnodigingsbrief voor de oprichtingsbijeenkomst van de ASSA worden die kwalen nog eens opgesomd:

'Dear Sirs,

Our attention has lately been called to the importance of some organization in the United States, both local and national, whose object shall be the discussion of those questions relating to the Sanitary Condition of the People, the Relief, Employment, and Education of the Poor, the Prevention of Crime, the Amelioration of the Criminal Law, the Discipline of Prisons, the Remedial Treatment of the Insane, and those numerous matters of statistical and philanthropic interest which are included under the general head of "Social Science".12

Deze brief is geschreven door Franklin Sanborn, secretaris van de in 1863 ingestelde Massachusetts State Board of Charities. In de Verenigde Staten is deze 'Board' de eerste staatscommissie op het gebied van liefdadigheid. Haar instelling marqueert tot op zekere hoogte een nieuwe fase in de Amerikaanse geschiedenis.

Tot in de Burgeroorlog was liefdadigheid een lokale aangelegenheid; iedere gemeente was zelf verantwoordelijk voor de opvang van armen, geesteszieken, kreupelen en blinden. Vooral door de aanhoudende en ook steeds groter wordende instroom van immigranten raakte dit lokale systeem echter in het ongerede. Onder druk van de omstandigheden - de burgerij vreesde de controle over de behoeftigen te verliezen werd armoede steeds meer een probleem voor de centrale overheden. Niét alleen in Massachusetts, maar daarna ook in andere staten, stelden de (Republikeinse) gouverneurs commissies in die toezicht moesten houden op filantropische instellingen. Deze commissies kregen bovendien tot taak voorstellen te ontwikkelen voor een betere organisatie van de liefdadigheid. 13

Alhoewel de opkomst van het verschijnsel Sociale Wetenschap niet simpelweg kan worden verklaard uit de instelling van dergelijke staatscommissies, vormen ze voor Sanborn en de zijnen well de directe aanleiding voor het oprichten van de ASSA. De noodzaak tot het centraliseren van taken en bewoegdheden op het terrein van lief- 
dadigheid gebiedt het verwerven van een nieuw type kennis. Zolang filantropische kwesties op lokaal niveau kunnen worden geregeld, is het onnodig of irrelevant vragen te stellen als: wat is het totaal aantal armen; waar bevinden ze zich; wat zijn, in het algemeen, de oorzaken van armoede? Een meer centrale aanpak van sociale vraagstukken roept dergellike vragen echter wel op. De ASSA dient zich aan als de leverancier van deze nieuwe kennis.

De ASSA stelt zich tot taak zoveel mogelijk feiten te vergaren op sociaal gebied. Sanborn en zijn medeoprichters van de ASSA denken dat sociale hervormingen uitblijven of tekortschieten, omdat men niet bekend is met die feiten. De ASSA houdt jaarlijks eem congres en geeft vanaf 1869 een eigen tijdschrift uit: de Joumal of Social Science. Toch heeft ze duidelijk een ander karakter dan de later ontstane professionele verenigingen. De leden delen niet een beroep, maar een bepaalde, nog nader te omschrijven mentaliteit. $\mathrm{Zij}$ vormen een losse associatie van sociaal bewogen, maar toch traditioneel denkende notabelen; een organisatie geleid door literair georiënteerde publicisten en gerenommeerde naturwetenschappers en wiskundigen. Een arbeidsdeling naar disciplines is hen vreemd, al voeren de oprichters van de ASSA naar het voorbeeld van een soortgelijke organisatie in Engeland wel een verdeling naar aandachtsgebieden in. Binnen de vereniging worden daartoe vier afdelingen gevormd, departments genoemd. Het eerste departement concentreert zich op problemen rond opvoeding en opleiding, het tweede op problemen van publieke gezondheid en het derde op sociaal-economische problemen als armoede en werkeloosheid. Het vierde departement is de juridische afdeling. Het heeft ondermeer tot taak voorstellen uit de drie andere departementen uit te werken tot wetsvoorstellen. ${ }^{14}$

\section{Frankdin Sanborn}

Franklin Sanborn (1831-1917) neemt niet alleen het initiatief tot de oprichting van de ASSA; tot 1898 vervult hij tevens belangrijke functies binnen de vereniging. Aan de hand van zijn opvattingen kan een indruk worden gegeven van het binnen de ASSA heersende denkklimaat.

Het eerste nummer van de Joumal of Social Science opent met een door Sanborn opgestelde verklaring waarin het doel en de werkwijze van de nieuwe wetenschap uiteengezet worden. ${ }^{15}$ Sociale Wetenschap, zo wordt daarin nadrukkelijk gesteld, is een heuse wetenschap: 'Its character as a Science needs not to be questioned'. 16 Waarom niet? De beginselverklaring geeft drie redenen, waarvan de eerste al is genoemd: Sociale Wetenschap verzamelt feiten op sociaal gebied. Maar daarnaast is Sociale Wetenschap ook een wetenschap vanwege de doelen die ze nastreeft. Sociale Wetenschap 'aims at strengthening, rather than undermining, the constitution of society". Daarom verschilt Sociale Wetenschap duidelijk van het socialisme, stelt Sanborn, want dat is een destructieve visie op de samenleving. In de tweede plaats dient Sociale Wetenschap te worden onderscheiden van liefdadigheid. Filantropie blijft aan de oppervlakte, 'takes things as they appear'. Zoals het een wetenschap betaamt, graaft Sociale Wetenschap dieper: 'It goes behind the effect to the cause, and tries to prevent, even more than to relieve, the errors existing among men'. ${ }^{17}$

Het kennen en het verbeteren van de samenleving worden in de beginselverklaring uit 1869 duidelijk in elkaars verlengde geplaatst. Tussen wetenschap en hervorming 
bestaat voor Sanborn geen conflict, ook later niet. Sociale Wetenschap heeft een dubbele plicht, merkt hij in 1884 op: geduldig leren wat is en vlijtig bevorderen wat moet zijn. ${ }^{18}$

\section{Karaktervorming}

Evenals in veel Europese landen is in de Verenigde Staten de opkomst van sociale wetenschap nauw verbonden met de uitbreiding en centralisering van overheidstaken. ${ }^{19}$ De Amerikaanse protagonisten van Socialle Wetenschap zijn er echter niet bewust op uit de rol van de staat te vergroten. Met 'the constitution of society", die, zoals Sanborn in het eerste nummer van de Joumal of Sacial Science verklaart, door de Sociale Wetenschap versterkt moet worden, is dan ook niet de staat bedoeld. Evenals veel van zijn generatiegenoten is Sanborn sterk beïnvloed door Ralph Waldo Emerson, die verklaarde: 'Every actual State is corrupt'.

De staat is voor Emerson een noodverband; ze ontleent haar bestaansrecht louter aan het feit dat ze de mogelijkheid biedt mensen op te voeden tot karaktervolle oftewel wijze individuen: 'That which all things tend to educe; which freedom, cultivation, intercource, revolutions, go to form and deliver, is character; that is the end of Nature, to reach unto this coronation of her king. To educate the wise man the State exists, and with the appearance of the wise man the State expires. The appearance of character makes the State unnecessary,. ${ }^{21}$

Ook Sanborn, die als jongeman nauw contact had met Emerson en de (literaire) vriendenkring rondom deze invloedrijke dichter en filosoof, legt een relatie tussen karaktervorming en het overbodig worden van centrale overheden. Sociale Wetenschap, zo betoogt hij in 1884, kan ertoe bijdragen dat de Verenigde Staten zich ontwikkelen tot een gemeenschap van individuen met een hoogstaand karakter, een gemeenschap die uiteindelijk ieder staatsgezag overbodig maakt.

Het begrip karakter bezit in de 19 e eeuw een groot verklarend vermogen. De plaats die mensen op de maatschappelijke ladder innemen, wordt door hun karakter bepaald; oorlogen wint men als men meer karakter heeft dan de tegenpartij; kunst heeft kwaliteit omdat de scheppers ervan een groot karakter bezitten; enzovoort. Karakter wordt in dit verband meestal opgevat als een bundeling van latente krachten die aan menselijk gedrag ten grondslag liggen. Het begrip verwijst niet alleen naar wilskracht, maar ook naar oordeelskracht, scheppingskracht en morele kracht. De nadruk die Emerson en Sanborn leggen op karaktervorming staat dus niet op zichzelf. In de Verenigde Staten is tot ver in de 19 e eeuw zelfs het gehele systeem van hoger onderwijs op dat doel afgestemd.

Kort na de Burgeroorlog vindt het hoger onderwijs nog geheel en al plaats binnen de traditionele 'colleges'. Het woord 'universiteit' wordt well al gebruikt, maar betekent nog weinig meer dan 'een college met een grote bibliotheek'. Deze altijd aan een kerkelijke groepering gelieerde 'colleges' zijn anders georganiseerd dan de latere universiteiten. Aan onderzoek in hedendaagse zin wordt geen aandacht besteed; studenten worden niet opgeleid tot een specifiek beroep en studeren dan ook niet in een bepaalde wetenschap af. Wat men op het 'college' leert is bovenal mentale en morele discipline. ${ }^{22}$

Achter de nadruk op karaktervorming gaat een zeker individualisme schuil. Maar individualisme is er in verschillende soorten en maten. ${ }^{23}$ Docenten van colleges kennen op maatschappelijk gebied slechts moreel-religieuze problemen. Hét tekstboek voor de bespreking van sociale kwesties is bij hen de Bijbel. Voor Emerson, die de studie van 
Aschylus, Dante en Shakespeare boven mentale gymnastiek en bijbeltraining stelt, wijzen maatschappelijke problemen niet op een tekort aan vroomheid maar op een gebrek aan cultureel niveau. 'The whole state of man is a state of culture', stelt Emerson in zijn essay 'Character' ${ }^{24}$ Ook Sanborn, die in zijn geschriften veelvuldig gebruik maakt van literaire citaten, blijf in dit opzicht een aristocraat, al legt hij een wat ander accent dan zijn leermeester. Sanborns ideaal is niet de gemeenschap van individuen, maar een gemeenschap van individuen. Het versterken van de constitutie van de samenleving betekent voor Sanborn vooral de versterking van individuele karakters, opdat zij in harmonie kunnen samenleven. Maar dit houdt niet in dat Sanborn de oorzaken voor het mog zwakke karakter van de maatschappelijke constitutie uitsluitend terugvoert op de leefwijze van de individuele Amerikaan. De identitcit van zijn conceptie van Sociale Wetenschap wordt als het ware door deze ruimte tussen therapie en diagnose vastgelegd. Anders dan het stelsel van liefdadigheid richt Socjale Wetenschap zich op preventie, maar de weg waarlangs Sanborn en de zijnen veranderingen op sociaal gebied tot stand willen brengen, loopt niettemin uitsluitend via de opvoeding van individuele burgers. Door hen de door de ASSA blootgelegde feiten te tonen, zo is de gedachte, zullen zij er vanzelf toe overgaan 'the errors existing among men' te corrigeren. ${ }^{25}$ Feiten voeden op, ze vormen ons karakter.

\section{Strijd om de beschaving}

Sociale Wetenschap bestrijkt een breed terrein. Men houdt allerlei enquêtes en pioniert op het gebied van beschrijvend statistisch onderzoek. Op de congressen van de ASSA wordt ondermeer gesproken over de noodzaak van hygiëne, over nieuwe manieren om krankzinnigen te verplegen, over het instellen van onderwijsinspecties, over rente- en prijstheorieen en over het stimuleren van de morele statistiek. Er is zelfs ruimte voor een voordracht over the increasing necessity of a care of the forests. ${ }^{26}$ Dit wijde spectrum aan onderwerpen overziend, lijkt Sociale Wetenschap een tamelijk leeg begrip, maar voor Sanborn en zijn tijdgenoten is het geen probleem dat Sociale Wetenschap de meest uiteenlopende thema's omvat. Aandacht voor zowel opvoeding, gezondheid, economie en recht, schrijft Sanborn in 1869 , is ecrder een voordeel dan een nadeel: "It is a safeguard against narrownes of opinion or exertion'. ${ }^{27}$

Ook later, wanneer historici en economen eigen beroepsverenigingen hebben gevormd en de aanduiding 'sociale wetenschappen' de eerdere term Sociale Wetenschap verdringt, blijft Sanborn vasthouden aan de gedachte dat de sociale wetenschappen een hechte eenheid dienen te vormen. Enigszins vermanend merkt hij in 1884 op: "It was Cicero who pointed out, in a well-known passage, that all the arts pertaining to culture are linked in one chain, and hold a sort of relationship to one another; each suggesting, if not accompanying a kindred train of "its sisters, its cousins and its aunts." Particularly is this saying true of the social sciences, which appear as a family gathering on Thanksgiving dinner, spread out under the banyan branches of the tree of knowledge'. ${ }^{28}$ Als brengers van beschaving dienen de sociale wetenschappen samen op te trekken, is Sanborns boodschap. Ieder onderling conflict is a warfare worse than civil, for the antagonists are brothers and sisters, like the Theban princes of the old Greek tragedy".99

Sanborns verzet tegen elke tegenstelling en tegen iedere opsplitsing in de sociale wetenschappen heeft, naast een cultureel aspect, ook een methodologische achtergrond. 
Theoretische discussies worden binnen de ASSA niet erg belangrijk gevonden. Zij die voordrachten houden op haar congressen - meestal mensen uit de praktijk, zoals gevangenisdirecteuren en leden van staatscommissies - zijn op grond van een moreel doel met elkaar verbonden en geven daaraan inhoud door het aanleveren van empirische informatie. Deze inductieve stijl van wetenschap werkt een coôperatieve instelling in de hand; via het vergaren, classificeren en uitwisselen van feiten brengt men gezamenlijk de wereld in kaart. ${ }^{30}$

Sanborns pleidooi voor wetenschappelijke eenheid heeft tenslotte ook een politieke achtergrond. De beschavingsarbeid die Sociale Wetenschap verricht, bevordert het ontstaan van een civilisatie zonder maatschappelijke conflicten en politieke tegenstellingen. "There will be throughout the world what the American patriot sighed for long ago - "no North, no South, no East and no West", voorspelt Sanborn. ${ }^{31}$ Alles wat de mensheid verdeelt, en daartoe behoort ondermeer de staat als politiek machtsapparaat, staat daarom haaks op de intenties van de Sociale Wetenschap. De opkomst van Sociale Wetenschap is in dit opzicht nauw verbonden met de beweging voor 'civil reform'. Bij deze relatie sta ik wat langer stil.

\section{Herstel van de oude orde}

De machtsuitbreiding van centrale overheden en het daarmee toegenomen machtsmisbruik van politici dreigen in de ogen van de intellectuele middenklasse, waartoe Sanborn behoort, de Amerikaanse democratie steeds meer te ontwrichten. De kritiek richt zich vooral tegen het zogenoemde 'spoilsystem': overheidsbetrekkingen worden verkregen op grond van bewezen (partij)politieke diensten, niet op grond van deskundigheid. Via een hervorming van deze praktijk hoopt men te kunnen terugkeren naar een vorm van democratie zoals die de 'Founding Fathers' oorspronkelijk voor ogen stond: een democratie waarin politiek leiderschap niet toevalt aan ongeletterde partijbonzen en immorele zakenlieden, maar uitsluitend aan "men of quality" ${ }^{32}$

Terwijl vóor de Burgeroorlog de oorzaken van publieke problemen niet of nauwelijks in een gebrek aan professionele deskundigheid worden gezocht, worden kwaliteit en deskundigheid na deze oorlog in toenemende mate opgevat als eigenschappen waaraan het de Amerikaanse cultuur ontbreekt. Het is een teken dat de intellectuele stand - 'the gentry class' - zich in het defensief gedrongen voelt: Juristen, medici, dominees en andere 'college'-docenten zijn van oorsprong degenen aan wie culturele autoriteit toevalt. $\mathrm{Zij}$ leggen vast in welke termen de wereld beschreven en begrepen dient te worden. Maar de competentie van deze traditionele beroepsgroepen om te oordelen over maatschappelijke kwesties staat tijdens de eerste helft van de 19e eeuw voor het eerst openlijk ter discussie. Met name politici en ondernemers veranderen van bondgenoten in rivalen.

'Commerce and civilization go hand in hand' kan men in de eerste helft van de $19 \mathrm{e}$ eeuw nog uit de mond van zakenlieden vernemen. ${ }^{33} \mathrm{Zij}$ hadden dan ook veelal het 'college' bezocht waar het onderricht in de politieke economie sterk moreel gekleurd was. De auteur van het best verkochte economieboek uit die tijd schreef in zijn voorwoord: 'The principles of political economy are so closely analogous to those of Moral Philosophy that almost every question in the one may be argued on grounds belonging to the other. ${ }^{34} \mathrm{Na}$ circa 1860 zijn zakenlieden en ondernemers echter voldoende 
geemancipeerd om hun maatschappelijke rol in eigen termen te kunnen rechtvaardigen. Eens werd ondernemerschap verdedigd met het argument dat het de culturele standaard verhoogt, nu wordt ondernemen gelegitimeerd op grond van het feit dat het maatschappelijke rijkdom schept. ${ }^{35}$

Op het politieke vlak is sprake van een soortgelijke ontwikkeling. Politiek bedrijven wordt een beroep dat zich zelfstandig kan legitimeren. Professionele politici plaatsen de sfeer van de politiek buiten (en boven) die van moraal en cultuur, een ontwikkeling die op het eind van de $19 \mathrm{e}$ eeuw haar symbolisch hoogtepunt vindt in de figuur van de machtige boss' van Tammany Hall, George Washington Plunkitt. Zijn voornaam verhindert hem niet te verklaren dat intellectuele scholing en culturele vorming in het politieke leven slechts een handicap zijn: "Some young men think they can learn how to be succesful in politics from books, and they cram their heads with all sorts of college rot. They couldn't make a bigger mistake. Now, understand me, I ain't sayin' nothin' against colleges. I guess they have to exist as long there's bookworms, and I suppose they do some good in certain ways, but they don't count in politics' ${ }^{36}$

Politiek en economie ontwikkelen zich na de Burgeroorlog kortom tot professies die de rol van de 'beschaafde' stand in het openbare leven aantasten. De man van aanzien en karakter dreigt een maatschappelijke buitenstaander te worden. De promotie van Sociale Wetenschap is én van de pogingen dat gevaar te keren; ze zou met name de culturele autoriteit van de oude intellectuele beroepen een nieuw, wetenschappelijk fundament kunnen verschaffen. ${ }^{37}$ Daartoe is het scheppen van een nieuwe professie onnodig, iets wat Sanborn en andere leiders van de ASSA ook nooit hebben nagestreefd. Hun wetenschap wordt niet bedreven door Sociale Wetenschappers, maar door medici, juristen en een rijk geschakeeerde groep van 'opvoedkundigen'. In de ogen van Sanborn vereist de nieuwe wetenschap dan ook geen nieuwe professionele competenties; veeleer bundelt en verbreedt Sociale Wetenschap de bestaande competenties van intellectuele beroepsgroepen die van oudsher een leidende rol in het openbare leven hebben gespeeld. Dit is aan de organisatiestructuur van de ASSA ook af te lezen. De indeling naar 'departments' is afgestemd op de arbeidsdeling binnen de toenmalige professionele stand. De ASSA is zo ingericht dat er plaats is voor vertegenwoordigers uit nagenoeg iedere in cultureel aanzien staande intellectuele stand. ${ }^{38}$

In het licht van deze oogmerken is het niet vreemd dat op de congressen van de ASSA allerlei verschillende onderwerpen aan bod komen. Voor hen die een nieuwe discipline of professie in het leven willen roepen, zoals de latere academische sociologen, trekt louter een onsamenhangende stoet van sprekers voorbij. Maar de wirwar van thema's krijgt samenhang, zodra we ons rekenschap geven van de eigen aard en de culturele rol van Sociale Wetenschap. Alle voordrachten, hoe uiteenlopend ook, dragen bij aan het verbreden en verstevigen van het fundament waarop de autoriteit van de traditionele intellectuele beroepen berust.

\section{Herbert Spencer in Amerika}

In de eerste jaren van haar bestaan stuit de American Social Science Association nauwelijks op tegenstand. Vanaf het begin van de jaren zeventig worden de activiteiten 
van Sanborns vereniging echter vanuit twee hoeken bekritiseerd. $\mathrm{Zij}$ die het hoger onderwijs in de Verenigde Staten op een nieuwe leest willen schoeien, beginnen zich langzaam te distantiëren van de ASSA. Meer frontaal wordt de aanval ingezet door een kleine, maar luidruchtige groep aanhangers van de Britse fillosoof Herbert Spencer (1820-1903).

In 1872 verschijnt het eerste nummer van The Popular Science Monthly, uitgegeven en geredigeerd door Edward L. Youmans, de man die Spencer in Amerika bekend zou maken. $A \mathrm{l}$ in dit eerste nummer laat Youmans zich kritisch uit over de term Sociale Wetenschap. Deze wetenschap, schrijft hij, 'fails to connote any distinctive or coherent body of principles such as are necessary to constitute a science". ${ }^{39}$ Sociale Wetenschap noemt zich dan ook ten onrechte een wetenschap, concludeert Youmans. In feite, meldt Youmans in een volgend nummer, worden op de congressen van de ASSA alleen maar allerlei praktische kwesties besproken; een activiteit die meer weg heeft van het beoefenen van 'a social art' dan van echt wetenschappelijk werk. ${ }^{40}$

Youmans betwist het culturele gezag waar de leden van de ASSA aanspraak op maken. Omdat die autoriteit niet gefundeerd is op een juist begrip van wetenschap, brengen de leden van de ASSA het publiek op een dwaalspoor. De ASSA, schrijft hij in 1875, 'produces a mischievous confusion in the public mind'. ${ }^{41}$ De intellectuele munitie voor deze aanval komt rechtstreeks uit de koker van Spencer. Voor een spenceriaan is feitenkennis, hoe omvangrijk ook, op zichzelf nog geen wetenschappelijke kennis. Die kennis onderscheidt zich door haar systematisch karakter: alleen wie uitgaat van een coherent geheel van principes bedrijft wetenschap.

Spencers gedachtengoed raakt in de jaren zeventig en tachtig van de $19 \mathrm{e}$ eeuw in Amerika populair. Youmans Popular Science Monthly, waarin veel artikelen van en over Spencer verschijnen, bereikt de voor die tijd grote oplage van elf duizend exemplaren. Ook Spencers boeken verkopen naar verhouding zeer goed. Tussen 1860 en 1900 worden er bijna een half miljoen verkocht. ${ }^{42}$ Vanwaar die populariteit? Welke aantrekkingskracht bezit Spencers werk? Om op deze vragen een antwoord te vinden moeten we een ogenblik stilstaan bij de receptie en de inhoud van Spencers omvangrijke oeuvre.

\section{Tegen het utilisme}

In de herfst van 1882 reist Spencer drie maanden door de Verenigde Staten. Hij is er ondermeer te gast bij Andrew Carnegie, een puissant rijke staalfabrikant en devoot spenceriaan. Spencers vriendschappelijke banden met Carnegie hebben zijn aanzien onder 20e-eeuwse sociologen zeker geen goed gedaan. Het gangbaar geworden oordeel over Spencer is door Laeyendecker goed verwoordt: 'Comte wilde met behulp van de kennis van wetten de maatschappij zo goed mogelijk sturen in de richting van groter geluk voor de mensheid. Zo niet Spencer. Als een overtuigd liberaal huldigde hij de opvatting dat ingrijpen alleen maar schadelijk zou zijn. Het zou de zwakken in stand kunnen houden en het succes van de sterken kunnen tegengaan. Een dergelijke opvatting, die de pretentie droeg in de kosmische orde gefundeerd te zijn, makkte Spencer buitengewoon populair bij de liberale ondernemers: Vooral in Amerika was hij voor de grote zakenlui een favoriete ideoloog, die wetenschappelijk rechtvaardigde wat zij uit harde zakelijke overwegingen in praktijk brachten'. ${ }^{43}$ Deze interpretatie is echter op zijn minst eenzijdig. Ze gaat voorbij aan het feit dat tijdgenoten om geheel andere redenen door het werk 
van Spencer werden aangesproken. Meer dan de latere veroordeling maakt de toenmalige receptie duidelijk waarop Spencers populariteit in de Verenigde Staten berustte.

Tijdens het diner dat Spencer voor zijn terugkeer naar Engeland wordt aangeboden door een aantal van zijn Amerikaanse bewonderaars, haalt een van de aanwezigen herinneringen op uit de tijd dat hij kennismaakte met Spencers eerste boek, Social Statics. Het is de tijd van de Burgeroorlog, toen hij als soldaat in de Noordelijke legers het boek met zich mee droeg. Hadden de Zuidelijken U toen ook maar gelezen, zo spreekt hij Spencer toe, dan hadden de Noordelijken de lessen die Social Statics bevat er niet met geweld in hoeven te hameren. ${ }^{44}$

Social Statics komt uit in 1851, maar raakt pas rond 1860 in Amerika bekend. Het is inderdaad een boek dat de lezer wil onderwijzen, zoals uit de opening van het boek al blijkt: "GIVE US A GUIDE", cry men to the philosopher. We would escape from these miseries in which we are entangled. $A$ better state is ever present to our imaginations, and we yearn after it; but all our efforts to realise it are fruitless. We are weary of perpetual failures; tell us by what rule we may attain our desire.' ${ }^{5}$

In het boek beantwoordt Spencer deze roep naar een moreel houvast, zich daarbij afzettend tegen het utilisme van Jeremy Bentham en James Mill. Terwijl deze filosofen geen beroep meer wilden doen op een of andere morele intuitie (moral sense) voor het ontwikkelen van een ethische en politieke theorie, grijpt Spencer terug op inzichten vit de oudere traditie van de 'moral sense'-filosofie. Stel een utilist eens de vraag, aldus Spencer, waarom het geluk van de ene persoon net zo belangrijk is als dat van een ander. Dan weet hij of niet te antwoorden, of hij roept alsnog zijn morele intuîtie aan. Die intuïtie berust dan ook op een natuurlijk vermogen dat volgens Spencer de mens door God is meegegeven. Het ligt ten grondslag aan het menselijk streven naar individuele vrijheid en wit zich, zo voegt Spencer daar aan toe, vooral in het streven naar een politiek van 'laissez faire".

Deze stellingname is vaak misverstaan. Spencer bepleit niet een ongebreideld kapitalisme; bij hem staan andere oogmerken voorop. Het milieu waar Spencer uit voortkomt is dat van de Dissenters, een zwaar vervolgde religieuze beweging die zich had afgescheiden van de Engelse Staatskerk. Spencers pleidooi voor het minimaliseren van het staatsgezag is dan ook in belangrijke mate een pleidooi voor een staat die de Dissenters met rust laat. Wanneer Spencer het heeft over bewegingen waarin in zijn tijd de 'moral sense' concreet tot uiting komt, dan vormen niet voor niets de 'Anti-StateChurch Associations' zijn belangrijkste voorbeelden. ${ }^{46}$

\section{Streven naar perfectie}

Spencer valt het utilisme nog op een tweede punt aan. Terwijl verandering toch de wet van alle dingen is, houdt het utilisme merkwaardig genoeg geen rekening met het veranderlijke karakter van de menselijke natuur. Spencer wekt bij deze kritiek de indruk dat het hier een omissie betreft, maar in feite geeft hij een nieuwe betekenis aan het begrip "menselijke natuur". Voor de utilist zijn veranderingen in menselijk "gedrag niet direct relevant, want in zijn conceptie beïnvloeden die veranderingen geenszins de daarachter schuilgaande menselijke natuur. Sterker nog: van zo'n invloed kan geen sprake zijn, omdat het begrip 'menselijke natuur' bij hem duidt op datgene wat juist niet verandert. Deze positie, die later met behulp van darwiniaanse ideeën kon worden 
verdedigd, wijst Spencer af, daarbij gebruik makend van de evolutietheorie van Lamarck. Het begrip 'menselijke natuur' verwijst bij Spencer namelijk naar een progressief ontwikkelingspatroon in de menselijke soort. Wie de menselijke natuur op het spoor will komen, dient derhalve de geschiedenis van de gehele mensheid in ogenschouw te nemen; iets wat voor de utilist onnodig is. Ook bij Sanborn en zijn geestverwanten ontbreekt dit ontwikkelingsperspectief.

In de geschiedenis van de mensheid ontwaart Spencer de werking van een universele evolutiewet die de mensheid naar een steeds hogere graad van perfectie voert. Uitgangspunt voor deze observatie is dat de mensheid zich altijd aanpast aan zijn omgeving. Dit proces heeft een eenduidige richting: onder invloed van gunstige omstandigheden hebben de reeds bij de eerste mensen latent aanwezige vermogens zich langzaam kunnen ontwikkelen. Hoe zulke gunstige omstandigheden tot stand gekomen zijn, kan Spencer in het midden laten. Het gaat hem er om aan te tonen dat als zij zich voordoen, ook altijd de gelegenheid wordt aangegrepen een hoger stadium van perfectie te bereiken. Terugval, na eenmaal op een hoger plan van beschaving te zijn beland, is onmogelijk. Spencer neemt met Lamarck aan dat 'aanpassing aan de omgeving' wordt overerfd.

'De eerste tijd', laat Tsjechow in een verhaal een minnaar zeggen, 'was alles rozegeur en maneschijn, kussen, gezellige avondjes samen, geloften, Spencer, idealen en gemeenschappelijke interessen $(. ..){ }^{47}$ Spencer stelt in het midden van de $19 \mathrm{e}$ eeuw zijn lezers inderdaad gerust. In deze tijden van oorlog en revolutie leert hij hen te vertrouwen op de nieuwe zekerheden van de natuurwetenschappen, zekerheden die er op wijzen dat christelijke deugden, moreel gevoel en liberale principes - al datgene waarover twijfel begon te rijzen - juist de toekomst hebben. De mensheid, zo toont hij aan, kent een universeel streven naar perfectie. Daarbij ontkent Spencer niet dat het beschavingsproces ook veel gruwelijkheden met zich mee heeft gebracht. De slavernij is er een voorbeeld van. Maar zodra Spencer dit onderwerp aanroert, voegt hij er dadelijk aan toe: 'Let not the reader be alarmed: Slavernij is een voorbijgand fenomeen. Dit in het zuiden van de Verenigde Staten nog aan te treffen verschijnsel is niet meer dan een restant van een achter ons liggende fase in het beschavingsproces. In de ogen van Amerikaanse lezers die aan de zijde van de Federalisten vochten, heeft Spencer van Lincolns morele overtuiging zo een (natuur)wetenschappelijke zekerheid gemaakt.

\section{Een kosmologie}

Na de publikatie van Social Statics zet Spencer de zoektocht voort naar een nietutilistische maar toch wetenschappelijke moraal. In 1860 verschijnt de prospectus waarin Spencer een monumentaal project aankondigt: zijn vijf delen omvattende Synthetic Philosophy. In het eerste deel, First Principles geheten, zullen de fundamentele uitgangspunten van alle wetenschapsbeoefening viteen worden gezet Daarna volgen The Principles of Biology, The Principles of Psychology en The Principles of Sociology, waarna het werk besloten wordt met een boek over "the principles of morality". Voortbouwend op de generalisaties 'furnished by Biology, Psychology and Sociology' zou dit viffde boek de raison d'etre van het gehele project dienen te bevatten: 'a true theory of right living. ${ }^{48}$ Spencer is een vasthoudend man en hij slaagt er in zijn woord gestand te doen: in 1893 heeft hij zijn synthetische filosofie in haar geheel voltooid. ${ }^{49}$

Het is een ironie van de geschiedenis dat Spencer voornamelijk nog figureert in de 
geschiedenis van de biologie en de sociologie. Alleen al de opbouw van zijn Synthetic Philosophy geeft aan, dat zijn biologische en sociologische beschouwingen deel uitmaken van een veelomvattend 'filosofisch' project. Synthetic Philosophy is als geheel genomen een breed opgezette kosmologie.

In Spencers uiteenzetting van de opbouw van ons heelal is God naar de achtergrond gedrongen; anders dan in zijn vroege werk neemt de realiteit nu geheel en al de gedaante aan van een gedetermineerd krachtenspel. Alle verschijnselen zijn een samenstelling van materie en energie, verklaart Spencer. Deze monistische veronderstelling stelt hem in staat talloze analogieredeneringen op te zetten. De werking van organismen wordt in fysische termen beschreven en de samenleving vergelijkt hij met een organisme. Maar ook het omgekeerde komt voor: Spencer begrijpt biologische fenomenen soms naar analogie van maatschappelijke structuren. ${ }^{\mathbf{5 0}}$

Hetzelfde monisme maakt het mogelijk iedere vorm van ontwikkeling te vatten onder een algemene evolutiewet; een wet die niet aan Darwin, maar aan de Duitse bioloog $K$. $E$ von Baer is ontleend. ${ }^{51}$ In de evolutie van het heelal, in de ontwikkeling van eicel tot baby, in de geschiedenis van de mensheid; telkens bespeurt Spencer dezelfde wetmatigheid die hij omschrijft als 'a change from an incoherent homogeneity to a coherent heterogeneity. ${ }^{\text {s2 }}$

Spencer volgt niet alleen ontwikkelingen in de biologie op de voet, ook "ontdekkingen' uit de toenmalige fysica incorporeert hij in zijn filosofie. Zo krijgt in de tweede helft van de $19 \mathrm{e}$ eeuw het denken over de aard van de kosmos een nieuwe impuls door de ontdekking van een wet die zeker evenveel indruk maakt als Darwins evolutietheorie: de wet van het behoud van energie. Deze wet brengt ogenschijnlijk geheel verschillende verschijjnselen, zoals mechanische arbeid, warmte en elektriciteit, onder eén noemer door ze op te vatten als in elkaar omzetbare krachten; dit resultaat gaf voedsel aan de hoop dat in de nabije toekomst een verdergaande uniformering van onze kennis tot de mogelijkheden behoort. Spencer heeft daar echter niet op willen wachten. In het monisme dat hij verdedigt, spreekt Spencer niet alleen van fysische krachten, maar ook van vitale, mentale en sociale krachten. Deze vier krachten stelt Spencer op eén lijn: alle vier zijn uitingsvormingen van dezelfde kosmische energie en derhalve in elkaar omzetbaar. Op grond van deze gedachte is het begrijpelijk dat Spencer biologie, psychologie of sociologie niet opvat als soevereine disciplines. Alhoewel elke wetenschap haar eigen 'principles' kent, grijpen niettemin alle wetenschappen direct op elkaar in. Iedere wetenschap is een inherent onderdeel van de leer van de kosmos.

\section{Terug naar Amerika}

In de Verenigde Staten lopen de reacties op Spencers Syntheric Philosophy sterk uiteen. Social Statics vond ook in academische kringen enig gehoor, maar Spencers latere werk ontlokt bij hen grotendeels negatieve reacties. Te materialistisch en antireligieus, luidt het vonnis. Tijdens zijn rondreis door de Verenigde Staten bezoekt Spencer dan ook geen enkel college of universiteit. Spencers sympathisanten, van wie niemand een universitaire positie bekleedt, prijzen daarentegen juist Spencers morele idealisme. Spencer laat zien dat wetenschap het - morele - medicijn is tegen het kwaad van deze tijd, zo legt Edward Youmans de lezers van zijn Popular Science Monthly uit. Het kwaad waarop hij doelt, heet - evenalls bij de leden van de ASSA - corruptie. De wetenschap 
zou uitkomst kunnen bieden voor kwalen als politieke zwendell, speculatie en de praktijken van wealthy mining interests'. 53

Spencer valt Youmans bij tijdens het al gememoreerde afscheidsbanket. Hij waarschuwt dat de Amerikaanse passie voor 'business" en 'money getting' de evolutie van de menselijke soort bedreigt. Ook nu stelt hij zijn gehoor echter dadelijk gerust. Want al overheerst tegenwoordig het streven naar materiële overvloed, het proces van evolutie leert ons dat in de naaste toekomst de menselijke energie op een meer heterogene wijze zal worden aangewend dan nu gebeurt. Bovendien zal met de groei van het individualisme ook de 'moral sense" - en daarmee het altruilsme - zich verder ontwikkelen: 54

De toekomst blijkt niet op Spencers hand en na het bezoek aan de Verenigde Staten verliezen zijn publikaties hun optimistische toon. Spencer begint nieuwe ontwikkelingen te hekelen, zoals de toenemende staatsinvloed, de vorming van industriële monopolies en het groeiend imperialisme. ${ }^{55}$ Zoals veel utopisten eindigt hij zijn leven als pessimist.

En Carnegie? Hoezeer hij Spencer ook vereerde en bleef vereren, hij is niettemin een geheel andere, meer moderne weg gegaan: De utopie van de klassiek-liberale Spencer is hem vreemd. Carnegie gaat het juist om de legitimering van trust- en monopolievorming. De concentratie van rijkdom, betoogt hij in 1900, 'is an evolution from the heterogeneous to the homogeneous, and it is clearly another step in the upward path of development'.56 Terwijl Spencer de evolutie zag als een beweging van homogeniteit naar heterogeniteit, zet Carnegie aan het begin van de $20 \mathrm{e}$ eeuw deze evolutiewet op haar kop.

Inmiddels is de Spencermode in de Verenigde Staten al voorbij. Weliswaar wordt Spencers werk nog steeds gelezen, maar dat gebeurt met andere bedoelingen dan voorheen. Terwijl Youmans een breed publiek tot Spencer wou bekeren, speelt Spencers gedachtengoed na 1880 voornamelijk nog een rol bij de pogingen een aparte sociologische discipline op te bouwen. Aan het verschil tussen de manier waarop Youmans en de eerste academische sociologen met Spencer omgaan, ligt een ontwikkeling ten grondslag die tevens tot de ondergang van de ASSA zal leiden. Als vanaf 1880 de eerste menswetenschappelijke disciplines zich gaan organiseren, verandert ook de wijze waarop culturele autoriteit nog valt af te dwingen. Als woorden nog enig gewicht willen hebben, dienen ze nu te worden uitgesproken door vertegenwoordigers van academische beroepen.

\section{Het effect van disciplinevorming}

In 1876 opent de Johns Hopkins universiteit in Baltimore haar poorten. Als eerste in de Verenigde Staten bezit deze universiteit een op onderzoek gerichte 'graduate school'. Haar oprichting marqueert het begin van een aantal ingrijpende hervormingen in het Amerikaanse hoger onderwijs. In het laatste kwart van de $19 \mathrm{e}$ eeuw krijgt het moderne universitaire systeem gestalte en verdwijnt het traditionele 'college' naar de achtergrond.

De grotere aandacht voor wetenschappelijk onderzoek geldt als een belangrijk kenmerk van deze vernieuwing. Toch is met die aandacht voor "research" niet dadelijk een duidelijk nieuwe opvatting verbonden over het doel van hoger onderwijs. Wanneer 
Gilman, de eerste president van Johns Hopkins, spreekt over de taken van de nieuwe universiteit, dan refereert hij aan het opvoedingsideaal van het traditionele college: Als het aan hem ligh, wordt de universiteit nooit "merely a place for the advancement of knowledge or for the acquisition of learning". Nee, 'it will always be a place for the development of character. ${ }^{57}$.

Gilman is naast onderwijsvernieuwer tevens een prominent lid van de ASSA. Toenemende specialisering is dan ook niet zijn ideal. Een samenleving opgebouwd uit louter specialisten noemt hij ronduit miserabel. Toch schept hij op Johns Hopkins onbedoeld een belangrijke voorwaarde voor het ontstaan van gespecialiseerde sociale wetenschappers. Op Gilmans conto staat namelijk de invoering van relatief zelfstandige universitaire 'departments'; een organisatorische verandering die al gauw ook door andere vernieuwers van het hoger onderwijs wordt doorgevoerd. Deze nieuwe organisatiestructuur is geent op universitaire hervormingen die eerder in Duitsland plaats hadden. ${ }^{58}$ Maar daarnaast vertoont ze overeenkomsten met de organisatie van de ASSA, zij het dat al snel een belangrijk verschil naar voren treedt. Anders dan in de ASSA gebruikelijk is, mengen de departementen van Gilmans universiteit zich niet in elkaars aangelegenheden. De hoofden van leder departement krijgen meer zeggenschap over het aantrekken van medewerkers en de opbouw van het curriculum, maar tegelijkertijd hebben ze buiten de grenzen van het eigen instituut geen bevoegdheden meer. ${ }^{59}$

Terwijl het traditionele 'college', met zijn ongelede organisatie en vastliggend onderwijsprogramma, slechts een onderverdeling naar jaargangen kent (aangeduid als freshman, sophomore, enz.), ontwikkelt het departement zich binnen de nieuwe universitaire structuur tot de belangrijkste basiseenheid. Daarmee dienen zich twee nieuwe verschijnsellen aan. Ten eerste gaat de competitie tussen docenten (wie krijgt een vaste aanstelling, wie een promotie?) zich nu afspelen binnen een departement. Daarmee wordt competitie, veel meer dan in het verleden, een vakinterne aangelegenheid. In de tweede plaats ontstaat er rivaliteit tussen departementen. Met de invoering van een soort van 'divisiestructuur' binnen het hoger onderwijs krijgen studenten namelijk de mogelijkheid een keuze te maken uit het onderwijsaanbod. Vooral bij het aantrekken van 'graduate' studenten worden vakgebieden nu elkaars concurrenten.

De invoering van het departement-systeem op Johns Hopkins heeft het proces van professionalisering een nieuwe impuls gegeven. Niet toevallig gaan initiatieven tot het reorganiseren van bestaande beroepsverenigingen en het oprichten van nieuwe organisaties in de meeste gevallen uit van docenten die aan Johns Hopkins verbonden zijn. Daarbij luidt vooral de oprichting van de American Historical Association, de American Economic Association en de American Psychological Assaciation (in respectievelijk 1884, 1885 en 1892) een nieuw type arbeidsdeling in op het gebied van de menswetenschappen. ${ }^{60}$

Terwijl de ASSA in principe open staat voor iedereen die toe wil treden, bezitten de besturen van deze nieuwe organisaties de bevoegdheid aanvragen voor lidmaatschap te beoordelen. Met deze statutaire vernieuwing krijgt de leiding de mogelijkheid 'amateurs" te weren. Maar die bevoegdheid roept tegelijkertijd de noodzaak op zich te bezinnen op de vraag waardoor het beroep van historicus, econoom of psycholoog zich nu eigenlijk kenmerkt. Deze zoektocht naar een eigen collectieve identiteit uit zich in alle nieuwe professionele verenigingen in pogingen om methode en object van het vak eenduidig vast 
te leggen. Naast het opbouwen van een organisatorische eenheid ontwikkelen de leiders van de nieuwe professies methodologische en theoretische standaarden op grond waarvan te bepalen is wat telt als historische, economische of psychologische kennis. Professionalisering en disciplinevorming zijn in dit geval twee zijden van eén medaille. ${ }^{61}$

Tegelijk met de opkomst van de nieuwe wetenschappelijke organisaties verliest de ASSA aan cultureel gezag, al blijft de organisatie nog tot 1908 jaarlijks bijeenkomen. Maar Sanborns Sociale Wetenschap heeft het dan, net als Spencers synthetische filosofie, al lang afgelegd tegen de disciplinaïr georganiseerde menswetenschappen.

\section{Disciplinevorming in de menswetenschappen: drie interpretaties}

De ondergang van Sanborns Sociale Wetenschap en Spencers synthetische filosofie is verschillend geduid. Om te beginnen is deze valk beschreven als een effect van het ontstaan van een andere houding ten opzichte van wetenschap. De generaties van Sanborn en Youmans zijn nog sterk praktisch georiënteerd; hun grote en nogal ideologisch gekleurde betrokkenheid bij sociale kwesties staat een meer gedistantieerde 'wetenschappelijke' houding in de weg. De vertegenwoordigers van de nieuwe menswetenschappen overtreffen hen in dit opzicht. Onderzoek, zo beginnen zij te beseffen, dient aan meningsvorming vooraf te gaan. In de balans tussen distantie en betrokkenheid wint het eerste element aan gewicht; zou Elias zeggen. ${ }^{62}$

Deze kenschets gaat er impliciet van uit, dat we veranderingen in houding op een rechte lijn kunnen afzetten. Het spreken over meer of minder distantie, meer of minder betrokkenheid, is echter alleen zinvol wanneer datgene waarop die houdingen zijn gericht - de realiteit in dit geval - niet zelf beweegt of verandert. Maar aan die voorwaarde is hier niet voldaan. Sociale Wetenschap, Spencers filosofie en de nieuwe menswetenschappen verwijzen namelijk geenszins naar een en dezelfde realiteit. De objectieve feiten die Sanborn meent bloot te leggen, zijn volgens Spencer weinig meer dan subjectieve denkbeelden die iedere wetenschappelijke systematiek ontberen; de kosmologische feiten waar de laatste over spreekt, worden op hun beurt door de volgende generatie academici als twijfelachtige speculaties aangemerkt.

Op grond van deze veranderde opvattingen over wat telt als 'de feiten', blijft het zeker mogelijk om vanuit Spencers standpunt Sanborn te weinig distantie toe te schrijven, of om vanuit een later standpunt ook Spencer een te betrokken houding toe te kennen. Maar daarmee zeggen we weinig meer dan dat de mate van distantie, die we een auteur toekennen, een functie is van de afstand van zijn opvattingen tot de onze. Wie voorgangers een geringere distantie tot 'de' realliteit toedicht dan zichzelf, verwijt hen in feite dat ze te weinig oog hadden voor wat men na hen als 'realiteit' is gaan beschouwen.

Wanneer de ontwikkeling van Sociale Wetenschap naar disciplinevorming klaarblijkelijk niet primair in psychologische houdingstermen te omschrijven is, hoe dan wel? Wellicht dienen we ons niet zozeer te richten op de instelling van de individuele wetenschapper, maar meer op veranderingen in de organisatie van wetenschapsbeoefening. Een tweede interpretatie kiest deze sociologische invalshoek: disciplinevorming wordt opgevat als een proces van sociale en cognitieve differentiatie. ${ }^{63} \mathrm{Zo}$ kan erop gewezen worden dat het organisatieprincipe van de ASSA verschilt van die van de nieuwe associaties, ook al bestaat tot circa 1890 het ledenbestand uit grotendeels 
dezelfde personen. Wat de leden van de ASSA onderling verbindt is vooral hun gedeelde maatschappelijke herkomst en niet de aard van hun beroep en roeping. In de nieuwe associaties komt daarentegen het zwaartepunt te liggen op het delen van dezelfde (beoogde) toekomst. $\mathrm{Zij}$ richten zich immers niet op het bundelen of versterken van competenties van reeds bestaande beroepsgroepen; hun doel is het creerren van een nieuw beroep en vakgebied. Wat bij voorbeeld de leden van de American Historical Association bovenal verenigt, is hun belangstelling voor en ook hun belang bij een zich ontwikkelende geschiedwetenschap.

Zodra de basis waarop men zich organiseert verschuift van herkomst naar toekomst, splitsen zïch snel de wegen. Niet alleen ontstaan er associaties rond de nieuwe universitaire beroepsperspectieven die zich inmiddels hebben aangediend. Tegelijkertijd vormen zich professionele associaties voor sociaal werk, gevangeniswerk, enzovoort. Toch zou het onjuist zijn deze differentiatie, voor wat de universitaïre beroepsperspectieven betreft, uit te leggen als het loslaten van praktische doeleinden waardoor meer objectief onderzoek mogelijk wordt - iets wat binnen deze tweede typering van de neergang van Sociale Wetenschap en Spencers filosofie vaak wordt gedaan. Differentiatie stelt men dan gelijk aan verwetenschappelijking, alsof de nieuwe generatie van menswetenschappers zich meer 'waardevrij' zou opstellen en haar aanspraak op cultureel gezag een meer zuiverwetenschappelijke grondslag zou krijgen. ${ }^{64}$ Deze typering is te onkritisch ten opzichte van de intenties van de betrokken vernieuwers en het beeld dat zij zelf hebben van hun activiteiten. Een derde interpretatie van de neergang van pre-disciplinaire wetenschapsbeoefening zet dat zelfbeeld tussen haakjes; in plaats van alleen te letten op veranderende intenties, richt ze zich ook (en vooral) op veranderingen in wetenschappelijke conventies. Met name veranderende conventies rondom verklaren zijn voor het proces van disciplinevorming relevant. ${ }^{65}$

\section{Grotere afstand tussen oorzaken en gevolgen}

De kern van iedere poging om de wereld om ons heen te verklaren, is een vorm van causale toerekening. Verklaren is het aanwijzen van oorzaken. Maar wie oorzaken aan wil wijzen, moet weten waar ze te vinden zijn. Welnu, in de loop van de $19 \mathrm{e}$ eeuw wordt de afstand tussen sociale verschijnselen en hun oorzaken groter gemaakt. Nabijgelegen oorzaken worden steeds meer gezien als gevolgen of effecten van meer afgelegen of dieper liggende oorzaken. Sociale Wetenschap zet reeds een stap in deze richting. Sanborn betoogt althans, zo zagen we, dat de oorzaken van sociale kwesties dieper liggen dan filantropen tot dan toe meenden. Toch liggen de oorzaken van sociale problemen voor Sanborn en zijn generatiegenoten in principe binnen handbereik. Om door te dringen tot de oorzaken van problemen als armoede of misdaad is geen speciaal vocabulaire vereist en ook is het niet nodig zich daarvoor vragen te stellen over de maatschappelijke orde als geheel. Want die orde is bekend: ieder mens is deel van Gods schepping. Hij heeft daarin een bepaalde plaats overeenkomstig zijn karakter en talenten. Mensen zijn nog zoals ze zijn; hetgeen niet weg neemt dat het 'betere' deel van de mensheid zekere plichten heeft tegenover minder bedeelde schepselen. Zoals de vader verantwoordelijk is voor zijn kinderen, zo zijn the well-endowed and succesful, the wise and educated, the honest and respectable' verantwoordelijk voor het compenseren van 'the failures of others'.66 
Tegen de achtergrond van dit weten, behouden problemen die zich aandienen steeds een lokaal karakter. Het zijn afzonderlijke storingen binnen een onproblematische orde en als zodanig ook afzonderlijk oplosbaar. Zo stipt de universiteitspresident A.D. White, in 1880 voorzitter van de ASSA, in zijn openingstoespraak op de algemene vergadering van dat jaar een groot aantal maatschappelijke kwesties op de volgende manier aan. Recentelijk, meldt White, is er door het Congres een wet aangenomen die het mogelijk maakt krankzinnigen over te plaatsen vanuit armenhuizen naar ziekenhuizen. Hij noemt dit een duidelijke vooruitgang en vraagt zich vervolgens af waarom het vele jaren moest duren voordat deze wet werd aangenomen. Zijn antwoord luidt: 'Simply because public opinion was not informed'. ${ }^{67}$ Te weinig mensen waren van de feiten op de hoogte, zodat de afgevaardigden onder te geringe druk stonden. Daarmee is alles over de kwestie gezegd. 'Take next the administration of our cities.' Dat onze steden uiterst slecht worden bestuurd, is duidelijk. En, meent White, "the cause is not far to seek". Het bestuur is in handen van "partisan mobs, with no proper check or balance". Liggen oorzaken nabij, dan is ook de oplossing binnen handbereik. Het volk moet gewoonweg bekend worden gemaakt met betere ideeën over het besturen van een stad. ${ }^{68}$

Doordat nieuwe disciplines als de geschiedwetenschap en de economie de afstand tussen maatschappelijke verschijnselen en hun oorzaken vergroten, slagen zij er beter in lokale problemen onder een algemene noemer te brengen. Allerlei op het eerste gezicht verschillende problemen worden gepresenteerd als effecten van vaak hetzelfde, voor leken onzichtbare proces. De vestiging van de geschiedwetenschap kan deze wending illustreren.

In de ASSA zijn historici niet met een apart "department" vertegenwoordigd. Voor de bespreking van actuele ontwikkelingen en problemen wordt de noodzaak van een aparte historische inbreng niet gevoeld. Verbazingwekkend is dat niet, gezien de stand van de Amerikaanse geschiedschrijving toentertijd. Het historisch beeld van Amerika kent nog geen eenheid, geen leidend motief. De scènes uit het verleden (koloniale tijdperk, revolutie, burgeroorlog) volgen elkaar slechts op. De notie van een 'dieper' liggend proces ontbreekt waarin die scènes geplaatst kunnen worden en waardoor ook een directe relatie met het heden te leggen valt. Een beroep op de (continentale) geschiedfilosofie biedt hier slechts gedeeltelijk uitkomst; de lijnen die zij trekt zijn universeel, niet specifiek Amerikaans van aard.

De historiografische vernieuwing die de opkomst van een professionele geschiedschrijving begeleidt, betreft vooral het uitwerken van een samenhangend perspectief op de eigen geschiedenis. De zogenoemde frontienthese van F.J. Turner biedt zo'n perspectief. $^{69}$ Op grond van het idee dat de trek naar het Westen het meest fundamentele proces in de Amerikaanse geschiedenis is, kunnen plotseling de verschillende historische scènes, alsook typisch Amerikaanse verschijnselen als individualisme en egalitarisme in éen beeld gevangen worden. Door het beeld van de zich verder naar het Westen verplaatsende 'frontier' kan Turners geschiedschrijving bovendien met actuele problemen worden verbonden. Zullen de stakingsgolven, de toenemende corruptie en de grote werkeloosheid niet allemaal effecten kunnen zijn van eén (diepere) oorzaak: het ontbreken van nieuw land? Immers, de Westkust is inmiddels bereikt. Moet derhalve de immigratiegolf niet worden ingedamd? Of zouden de Verenigde Staten toch moeten overgaan tot het voeren van een imperialistische politiek? Kortom, Turners verweten- 
schappelijking" van de geschiedschrijving maakt historische kennis juist politiek relevant.

\section{Collectivisering van de washeid}

Door disciplinevorming te verbinden met veranderingen in causale toerekening is de neergang van pre-disciplinaire wetenschapsbeoefening echter nog niet volledig getypeerd. Onduidelijk is nog in welk opzicht de aanpak van Turner en andere grondleggers van de nieuwe disciplines verschilt van Spencers verklaringsstijl. Ook Spencer zoekt de oorzaken voor sociale problemen immers niet om de hoek.

Tezamen met het zoeken naar 'diepere' oorzaken, veranderen evenwel ook de ideeën over hoe men die oorzaken bereiken kan. Wanneer de afstand tot de waarheid groter wordt, rijst de vraag of ledere wetenschapper wel op eigen kracht tot haar kan doordringen Een duidelijk antwoord ligt echter niet gereed. De pleitbezorgers van universitaire hervormingen ontbreekt het vooralsnog aan een kennistheorie die op het proces van professionalisering en disciplinevorming is toegesneden. Meer dan iemand anders voorziet de natuurkundige en filosoof Charles S. Peirce (1839-1914) in deze lacune.

Uit de snelle ontwikkeling van de natuur- en levenswetenschappen trekt Peirce de conclusie dat het waarmerk van wetenschap niet het bereiken van absolute zekerheid kan zijn. Zekerheden, zelfs wetenschappelijke zekerheden, kunnen elk moment veranderen in onzekerheden. Maar betekent dit dat we ons geloof in wetenschappelijke waarheid dus maar moeten inruilen voor totale twijfel, voor een radicaal scepticisme? Nee, betoogt Peirce in een aantal artikelen die dadelijk de aandacht trekken. ${ }^{70}$ Het dilemma blijkt vals zodra we inzien dat onderzoek altijd een collectief karakter heeft. Aan de bron van onderzoek ligt de strijd van een gemeenschap die, in zijn pogingen om tot vaste en gedeelde overtuigingen te komen, de steeds terugkerende twijfel wil uitbannen. Mar niet alleen draagt elk onderzoek in deze zin een social stempel, ook waarheid is geen individuele maar een collectieve zaak, betoogt Peirce. Waarheild omschrijft hij als 'the opinion which is fated to be ultimately agreed to by all who investigate:. Voor elk afzonderlijk individu, zo geeft Peirce met deze definitie aan, is waarheid onbereikbaar; alleen de wetenschappelijke gemeenschap als geheel mag hopen ooit toegang tot haar te krijgen 71

Peirce is in de Verenigde Staten de eerste filosoof die het collectieve karakter van wetenschap een kennistheoretisch fundament geeft. De nieuwe generatie van historici, economen en psychologen erkennen het belang van deze stap, zij het dat Peirces filosofische idee van een universele gemeenschap van competente onderzoekers door hen al snel een meer aardse inhoud gegeven wordt. In de praktijk wordt die abstracte gemeenschap namelijk gelijk gesteld met de eigen professionele gemeenschap. De binnen deze verenigingen geaccepteerde inzichten verkrijgen daardoor meer gewicht, want onderlinge overeenstemming in de eigen kring kan nu - anders dan Peirce had bedoeld als het teken van waarheid worden beschouwd.

\section{Disciplinaire versies van de wereld}

Veranderingen in de wijze waarop gebeurtenissen met elkaar in verband worden gebracht, hebben consequenties voor de verhouding tussen deskundigen en leken. Hoe dieper de ware" oorzaken gezocht moeten worden, hoe moeilijker de leek ze op eigen kracht zal kunnen ontdekken. Veranderingen in het zoeken van waarheid hebben op 
dezelfde manier zowel een sociale als een cognitieve kant. Enerzijds verandert de sociale basis waarop men zich organiseert (zoals ik al aangaf, sluit men zich minder op grond van dezelfde maatschappelijke herkomst aaneen), anderzijds leidt de nieuwe nadruk op het collectieve karakter van wetenschap tot een wijziging van de cognitieve functie van de verschillende verenigingen. De ASSA en de Spencergenootschappen dienen er nog toe de waarheden, die individuele leden aandragen, te verzamelen en publiek te maken. Ze hebben een soort museumfunctie en het beeld van wetenschap dat in deze verenigingen gangbaar is, sluit daarop aan: wetenschap is het verzamelen en classificeren van (nogal divers) feitenmateriaal. Daarentegen kennen de nieuwe professionele verenigingen zichzelf een soort rechtbankfunctie toe: zij zijn niet louter verzamelplaatsen voor waarheden of competenties, maar vooral de plek waar wordt bepaald wie een competente onderzoeker is en in welke richting waarheid gezocht dient te worden. De disciplinerende werking die van dit nieuwe beeld van wetenschapsbeoefening uitgaat, strekt zich tevens uit tot het afbakenen van gebieden waarover men recht van spreken opeist. Zodra wetenschappelijke collectieven zichzelf een rechtbankfunctie toeschrijven, proberen zij zïch ook een soevereine status te verwerven. Dat wil hier zeggen: zij streven nu niet meer alleen ten opzichte van religieuze en wereldlijke overheden naar autonomie, zoals in de tijd van Boyle en Kant, maar stellen zich ook ten opzichte van elkaar autonoom op. Het gevolg hiervan is dat de wereld langzamerhand haar eenheid verliest; achter de verscheidenheid van de feiten worden nu onafhankelijke werkelijkheidsgebieden geprojecteerd en afgebakend. Tegelijk met de vorming van bij voorbeeld een collectief van geschiedwetenschappers ontstaat een specifiek historische realiteit.

De ster van Spencer daalt als gevolg van deze veranderingen. In sociaal opzicht komt hij alleen te staan vanwege het feit dat hij een universeel geleerde is. Zulke types onttrekken zich aan de jurisdictie van de nieuwe professionele lichamen. Meer en meer worden ze gezien als dilettanten, als wetenschappelijke vagebonden. Tegelijkertijd raakt Spencer ook in cognitief opzicht een statenloos burger. Want zijn verklaringen mogen dan wel 'diepte' bezitten, het is een verkeerd soort diepte. Disciplinevorming betekent dat feiten en oorzaken steeds meer een disciplinair label krijgen; ze gaan tot een bepaalde discipline behoren. Historische feiten en oorzaken, economische feiten en oorzaken, psychologische feiten en oorzaken, enzovoort, komen bijgevolg naast en los van elkaar te staan. De 'great chain of being' wordt verbroken, doordat iedere discipline de soevereine rechten over een afgebakend domein claimt. Zo wint nog een andere nieuwe verklaringsconventie aan gezag, naast de al genoemde die de afstand tussen oorzaak en gevolg betreft; een conventie die zegt dat feiten binnen een bepaald disciplinair domein dienen te worden verklaard door oorzaken die ook binnen dat domein vallen. Historische feiten hebben uiteindelijk historische oorzaken, net zoals fysische feiten uiteindelijk fysische oorzaken kennen. Spencer kent deze conventie echter niet. Zijn realiteit is nog ongedeeld: het is een wereld waarin disciplinaire grenzen niet bestaan.

In de traditionele disciplinegeschiedenis wordt het werk van onderzoekers uit het verleden geïnterpreteerd vanuit de plaats die hen wordt toegedicht in de globale ontwikkeling van een vakgebied. Niet-finalistische geschiedschrijving kiest daartegenover de lokale situatie van de onderzochte en diens tijdgenoten als punt van vertrek, zonder 
hun handelen te beoordelen vanuit een reeds vooraf gegeven definitie van de identiteit van dat vakgebied. Wanneer we langs deze weg trachten de inzet van Sanborns en Spencers intellectuele activiteiten te achterhalen en in hun tijd te plaatsen, wordt duidelijk hoezeer er van reductie sprake is wanneer hun werk louter als een vroege bijdrage aan de sociologie wordt gezien. De sociale wetenschap die door Sanborn en andere leden van de ASSA wordt bedreven, staat in een andere context dan het werk dat door latere sociologen wordt verricht. Waar disciplinaire grenzen en verbanden ontbreken leidt de introductie van Sociale Wetenschap niet tot de vorming van een nieuwe wetenschappelijke gemeenschap en ontbreekt het streven haar identiteit in theoretisch of methodologisch opzicht nader vorm te geven. Sociale Wetenschap is niet met een nieuw beroepsperspectief verbonden, maar heeft tot inzet de opvoedende en leidende rol van de traditionele intellectuele elite een nieuwe grondslag te verschaffen. De Amerikaanse volgelingen yan Herbert Spencer hebben daaraan geen boodschap, al was het maar omdat zij meestal geen deel uitmaken van die elite. De filosofie van Spencer biedt hen de argumenten zich van de ASSA te distantiëren en doet hen beschikken over een wetenschappelijk onderbouwde moraal. Tegen die achtergrond is sociologie voor hen geen autonome wetenschap, maar inherent onderdeel van een kosmologie waarin de loop en het doel van de beschaving wordt ontvouwd.

$\mathrm{Na} 1880$ vinden op het wetenschappelijke toneel in de Verenigde Staten changementen plaats die zowel voor Sanborns ASSA als voor de volgelingen van Spencer nadelig uitvallen. Wanneer naast de natuur- en levenswetenschappen ook de menswetenschappen een disciplinaire opbouw krijgen, verliezen hun activiteiten aan wetenschappelijke legitimiteit en slinkt hun cultureel gezag. Binnen het decor van deze nieuwe orde krijgen Sociale Wetenschap en Spencers synthetische filosofie de status van figuranten; steeds meer worden ze beschouwd als niet-wetenschappelijke confessies. Willen hun erfgenamen zich niet laten meeslepen in deze val, dan dienen zij zich anders te organiseren en te presenteren. 


\section{Noten behorend bij hoofdstuk II}

1. Heilbron (1983): 29-51.

2. Zie Tolman (1901/1902); Turner and Turner (1990).

3. Laeyendecker (1981): 337.

4. Hinkle and Hinkle (1954).

5. Dahrendorf (1968): 111.

6. Vgl. Bledstein (1976): 86.

7. Zie Buck (1965).

8. Ook ten aanzien van de sociologie in andere landen is geprobeerd $z 0^{\circ} \mathrm{n}$ directe band te leggen met het 'karakter' van de maatschappij. Zie b.v. voor Duitsland Gorges (1986a) en Gorges (1986b); voor Nederland zie Gastelaars (1985).

9. K van het Reve heeft er op gewezen dat achter dit soort legendevorming vaak een cirkelredenering schuilgaat: 'Zeer populair is de opvatting, dat grote kunstenaars grote psychologen zijn. De redenering is deze: zie Hamlet, een man van die en die eigenschappen. Zie nu eens hoe keurig Shakespeare hem geschetst heeft! Shakespeare moet wel een geweldig, geniaal inzicht in de menselijke psyche hebben gehad! De cirkelredenering die hier gebruikt owrdt is dezelfde die men ook bij de sociologische aanprijzing van grote schrijvers vindt: de Franse of Russische Maatschappij van 1820 haalt men eerst uit Balzac of Gogol en daarma prijst men beide schrijvers dat zij die maatschappij zo goed hebben weergegeven. Eerst haalt men een beell van Hamlet uit het gelijknamige stuk. Dan vergelijkt men dat beeld met ... zichzelf, en zegt dat het precies lijkt". (Van het Reve (1970): 24.

10. Deze legende sluit aan bij het onderscheid dat in finalistische disciplinegeschiedenissen wordt gemaakt tussen de voorgeschiedenis en de 'eigenlijke' geschiedenis van een bepaald vakgebied. Die voorgeschiedenis krijgt daarin snel het karakter van een voorspel, alsof men dit toneel snel leeg maakt wanneer het 'echte' stuk begint. Vgl. Lepenies (1978).

11. Om verwarring met de latere betekenis te voorkomen schrijf ik Sociale Wetenschap met twee hoofdletters. Het begrip kent een Franse oorsprong; zie Baker (1960), Bryson (1931/1932).

12. ASSA (1866).

13. Zie Haskell (1977); KJein (1968).

14. Voor de geschiedenis van de ASSA zie Bernard and Bernard (1943); Haskell (1977); Ross (1991).

15. Introductory Note, in: Joumal of Social Science, no. 1, June 1869: 1-4.

16. Bij deze uitspraak moet wel bedacht worden dat het woord 'science' in het predisciplinaire tijdperk nog een ruime betekenis had. ledere systematische studie en ook ieder ambacht kon ermee worden aangeduid. Vgl. Williams (1981): 265-280.

17. Introductory Note: 3 .

18. Sanborn (1884): 7. Deze plicht staat in een religieus licht: 'We cannot too often consider and repeat that the origin of every science is divine', benadrukt hij. Ibid.: 9 . Vgl. ook Sanborn (1885).

19. Zie over deze relatie Wittrock et.al. (1991).

20. Emerson, 'Politics' in idem (1883): 199. Deze uitspraak staat in het volgende verband: 'Born democrats, we are nowise qualified to judge of monarchy, which, to our fathers living in the monarchical idea, was also relatively right. But our institutions, though in coincidence with the spirit of the age, have not any exemption from the practical defects which have discredited other forms. Every actual State is corrupt. Good men must not obey the laws too well. What satire on government can equal the severity 
of censure conveyed in the word politic, which now for ages has signified cunning, intimating that the State is a trick?"

21. Ibid: 206. Individualiteit, betoogt Emerson in zijn vroege werk, kan slechts verkregen worden buiten elk sociaal verband om. Het waarachtige individu overstijgt de maatschappelijke orde; het enige wat voor hem telt, is het rechtstreekse contact met de kosmische orde. Ongeveer vanaf 1840 begint Emerson meer aandacht te schenken aan maatschappelijke en politieke vraagstukken, maar ook dan blijft het individu zijn invalshoek. Vgl. Schneider (1957); Kucklick (1985).

22. Herbst (1988). Het doel studenten mentaal te disciplineren is onderdeel van een door invloedrijke college-presidenten als James McCosh (Princeton) en Noah Porter (Yale) ontwikkelde psychologie en filosofie. In hun denken, dat voortbouwt op het zogenaamde Schotse common-sense realisme, speelt het concept 'menselijke ziel' een fundamentelle rol. Van de ziel gaat een vitale kracht uit die op haar beurt zowel lichaam als geest activeert. Dit is mogelijk doordat de ziel verschillende - door God gegeven faculteiten kent, dat wil zeggen: bepaalde latente vermogens en potentiële talenten. Belangrijke faculteiten zijn wil, emotie, intellect en de 'moral sense'. Faculteiten komen uit zichzelf tot wasdom, maar om zich evenwichtig en volledig te kunnen ontwikkelen, dienen ze wel te worden geleid. Hiertoe, zo meende men, was formele educatie het middel. Een studieprogramma waarin veel Griekse en Latijnse grammatica, veel wiskundle en uiteraard een gedegen religieuze training voorkomt, zorgt voor een optimale ontplooiing van zowel de mentale als morele faculteiten. Zie McCosh, 1875 (1966). Vgl. Ahlstrom (1955), Kucklick (1985).

23. Vgl Swart (1962).

24. In Emerson (1883): 104. Karakter is bij Emerson een natuurlijke houding die mensen moeten hervinden door zich althans geestelijk van hun dagelijkse maatschappelijke banden te bevrijden; een opvatting die we bij voorbeeld ook bij de tot Emersons vriendenkring behorende Thoreau kunnen aantreffen. Bij Emerson is vooral literaire belezenheid essentieel voor de vorming van karakter.

25. Sanborn (1884): 8.

26. Gecit. in Haskell (1977): 110.

27. Sanborn (1869): 1 .

28. Sanborn (1884): $1 * 2$.

29. Ibid.: 2 .

30. Vgl. De Vries/Boon (1986).

31. Sanborn (1885): 4.

32. Vgl. Wiebe (1967).

33. Gecit. in Hofstadter (1963): 245.

34. Wayland (1837); iv.

35. Hofstadter (1963): 251.

36. Gecit. in Hofstadter (1963): 187.

37. Vgl. voor dit argument Haskell (1977); Silva and Slaughter (1984).

38. Naast de 'departments' voor Education, Social Health, Social Economy en Jurisprudence ontbrak weliswaar een department voor godsdienstzaken, maar dat gemis duidt niet op een gebrek aan invloed en participatie van theologen. Integendeel, 'sociaal voelende" religieuze leiders waren binnen elk "department" actief en hadden aan een eigen afdeling weinig of geen behoefte. Zie Haskell (1977).

39. Youmans (1872): 117.

40. Youmans (1873): 426.

41. Youmans (1875): 626.

42. Zie Bannister (1979) over de Spencer-receptie in de Verenigde Staten.

43. Laeyendecker (1981): 188. Laeyendecker ontleent zijn oordeel waarschijnlijk aan Hofstadter (1955). Dit boek heeft de beeldvorming van Spencer lange tijd bepaald.

44. Gecit. in Bannister (1979): 62.

45. Spencer (1851): 1 . 
46. Spencer (1851): 24. Vgl. Peel (1971).

47. Tsjechow (1891): 9.

48. Spencer (1862): xiii-xviii. Deze prospectus is bij wijze van voorwoord opgenomen in de eerste editie van First Principles.

49. Wel verschijnen de delen van Synthetic Philosophy in een wat andere volgorde dan aangekondigd. Zie over dit project Paul (1983).

50. Spencers organistische visie op de samenleving neemt niet weg dat zijn sociale filosofie individualistisch van aard blijft. In zijn kosmologie staat het individu op hetzelfde niveau als het atoom en de cel: alleen deze drie entiteiten kunnen volgens Spencer optreden als 'dragers van energie".

51. Zie Peel (1971): 136. Vgl. ook Smith (1982).

52. Spencer (1862): 291.

53. Gecit. in Bannister (1979): 71.

54. Ibid.: 78.

55. Spencer verstrekt o.a. de Japanse regering adviezen over hoe ze westerlingen het best op afstand kan houden. Zie 'Advice to the Modernizers of Japan", opgenomen in de bloemlezing Spencer (1972).

56. Carnegie (1900): 144 (mijn curs.).

57. Gecit. in Veysey (1965): 161.

58. Of eigenlijk: op het beeld dat men toen in Amerika van die hervormingen had. Vgl. Ringer (1979), Wachelder (1992).

59. Vgl. Manicas (1988), Oleson/Voss (1979), Veysey (1965).

60. Over disciplinevorming en professionalisering in de natuurwetenschappen, zie Keules (1979), Allen (1979), Warner (1991).

61. Vgl. Furner (1975).

62. Vgll. Elias 1956 (1982).

63. Zie b.v. Janowitz (1972).

64. Zie voor een kritiek op deze redenering Kucklick (1980a); Silva and Slaughter (1984).

65. Deze interpretatie is voor het eerst naar voren gebracht door Haskell (1977). Helaas beschouwt hij veranderingen in verklaringsconventies als een rechtstreekse afspiegeling van maatschappelijke ontwikkelingen. Omdat de samenleving complexer wordt, worden verklaringen betreffende die samenlevingen ook complexer, zo redeneert hij.

66. ASSA, Constitution (1866): 3.

67. White (1890): 1-20.

68. Die betere ideeen komen volgens White hierop neer: 'first, the idea that cities are not political bodies; that the question in electing a mayor or alderman is not what he thinks on national questions, but what he can do as to city questions. (...) The other idea is that, as the city is a corporation, as it has to do not at all with political interests, but with corporate interests, - paving, sewerage, lighting, water supply, the repression of crime, care of the public health, public comfort, public instruction -, those should have some control who have to pay for all these things." (White (1890): 13-14.) Whites kijk op maatschappelijke problemen is verwant aan die van de 'muckrackers' - een groep journalisten die rond de eeuwwisseling allerlei vormen van stedelijke en industriële corruptie aan de kaak stellen. Volgens de vertegenwoordigers van de nieuwe sociale wetenschappen blijven zij in hun reportages echter aan de 'oppervlakte"; een verwijt dat tegelijkertijd ook Sociale Wetenschap treft. Justin Kaplan geeft in zijn biografie van de 'muckracker' Lincoln Steffens een helder beeld van deze beweging als geheel. (Kaplan 1974) De studie van A.N.J. den Hollander over de 'muckrackers' wordt helaas door sociologische eigendunk ontsiert. 'Zelfs een middelmatig wetenschapsbeoefenaar', schrijft hij, "bereikt door de aard van zijn geestelijke gerichtheid, hem in den regel bijgebracht door zijn scholing en door de aard van zijn bedrijf, "vanzelf" heel iets anders en ook wel "beters" - wat betreft het vastleggen en doorgronden van sociale werkelijkheid - dan een 
briljant journalist wiens geestelijke gaven de zijne misschien in menig opzicht verre overtreffen: (Den Hollander (1976): 87-88).

69. Turner (1893). Vgl. Hofstadter (1968), Higham (1965).

70. Zoals 'Some consequences of four incapacities' (1868) en 'The fixation of belief (1878): opgenomen in Peirce (1931-1953). Peirce heeft de naam een miskend filosoof te zijn geweest. Dat zijn werk in de 20 e euw lange tijd vergeten raakte, staat echter los van het feit dat zijn "vroege' artikelen op het eind van de $19 \mathrm{e}$ eeuw in Amerika zeker niet onopgemerkt bleven. Vgl. Haskell (1977) en Haskell (1984).

71. Over de interpretatie van Peirces waarheidstheorie lopen de meningen uiteen. Volgens sommigen loopt de theorie vooruit op de 'naturalistische' ideeën over waarheid van James en Dewey. Anderen beklemtonen juist de verschillen en wijzen op de kantiaanse elementen in Peirces denken. Vgl. o.a. Apel (1967), Schuyt (1982). 


\section{III \\ TUSSEN CONFESSIE EN PROFESSIE \\ Over het maken van een sociologische discipline \\ in de Verenigde Staten}

\section{De genese van een discipline}

Een paleontoloog verbonden aan het geologisch museum in Washington D.C. publiceert in 1883 een lijvige studie onder de titel Dynamic Sociology. De oplage blifft grotendeels onverkocht en teleurgesteld houdt de auteur de sociologie voor gezien. Hij keert terug naar zijn oorspronkelijke interesse, publiceert biologische en geologische artikelen en doceert enige tijd plantkunde aan de universiteit van Columbia in New York: ${ }^{1}$ Het valt niet mee socioloog te zijn in een tijd dat het beroep nog niet bestaat.

Dynamic Sociology zou vergeten zijn geraakt als Albion W. Small (1854-1926), de president van een klein college aan de Oostkust, niet een deel ervan had opgenomen in een syllabus voor zijn studenten. De enthousiaste brief die Lester Ward (1841-1913), de schrijver van het boek, in 1890 van Small ontvangt, vormt het begin van een langdurige correspondentie en draagt ertoe bij dat Wards belangstelling voor de sociologie herleeft. ${ }^{2}$ Een en ander heeft er uiteindelijk toe geleid dat Ward in de sociologische disciplinegeschiedenis te boek is komen te staan als Amerika's eerste socioloog.

Gezien die latere aanduiding is Dynamic Sociology een merkwaardig geschrift. Ward schreef het niet om een bijdrage te leveren aan de opbouw van een aparte, sociologische discipline. Zijn oogmerk was het zeker stellen van de menselijke vooruitgang. Dynamische sociologie staat in Wards terminologie dan ook voor 'de gehele filosofie van menselijke vooruitgang'. Kern van zijn programma is het onderscheid tussen natuurlijke en artificięle vooruitgang. Alle vooruitgang is tot nog toe het produkt van natuurlijke selectie geweest, mar deze route is lang en bovendien ongewis. Een kortere weg ligt volgens Ward binnen handbereik; door het aanwenden van wetenschappelijke kennis kan de mensheid haar lot in eigen hand nemen. Hinderpaal voor het volgen van deze weg is naar Wards oordeel niet de nog gebrekkige staat van het kennisbestand. Er is juist een enorme hoeveelheid aan kennis beschikbaar, zowel over de natuur als over mens en maatschappij. Het probleem is meer dat "this mass of knowledge has remained locked up in the minds of a few persons: ${ }^{3}$ Ward laat zich in dit verband skeptisch uit over toentertijd al gangbare pleidooien voor meer onderzoeksfaciliteiten. Waarom doorgaan met het opsporen van nieuwe waarheden als het in de hedendaagse matschappij onmogelijk is een goed gebruik te maken van de kennis waarover we reeds beschikken? De uitbreiding van universitair onderwijs en onderzoek heeft in Wards "progressieve" 
fillosofie dan ook een lage prioriteit. Wat allereerst gebeuren moet, is brede verspreiding van de nu nog esoterische kennis.

Alvorens via populair wetenschappelijk onderwijs tot die verspreiđing te kunnen overgaan, dient de aanwezige kennis echter eerst te worden gesystematiseerd. Met een losse massa feiten kan niemand lets aanvangen: 'Unorganized knowledge can not be utilized". In de ordening die Ward vervolgens in Dynamic Sociology presenteert, wordt met behulp van aan Comte ontleende inzichten de synthetische filosofie van Spencer omgebouwd tot een 'progressief systeem van 'sociale krachten'.

Eenendertig jaar na de publikatie van Dynamic Sociology, in 1904, vinden we Ward terug in St. Louis, als spreker in de sectie Sociologie op het wetenschappelijk wereldcongres dat daar ter gelegenheid van de wereldtentoonstelling plaatsvindt. Zijn onderwerp is de oorsprong en evolutie van de samenleving. Het is een evidente waarheid, zegt Ward nu, dat de kosmische wetten die aan de opbouw van ons zonnestelsel ten grondslag liggen ook de oorsprong van menselijk samenleven hebben bepaald. In het begin groepeerden individuen zich samen tot clans die zogezegd op afstand om elkaar heen cirkelden. Toen de clans groter werden en het beschikbare voedsel schaarser, werd het evenwicht tussen aantrekking en afstoting verstoord. Onderlinge strijd en onderwerping van de ene clan door de andere was het gevolg. Hier ligt het beginpunt van de sociale evolutie en de maatschappelijke structuren die vervolgens ontstonden, ontwikkelden zich tot op heden op precies dezelfde manier als organische structuren. Was het maar zo, besluit Ward, dat iedereen bekend was met deze evolutionaire krachten. Op grond van die kennis zou de tot nu toe blinde en trage vooruitgang kunnen worden aangevuld met een doelbewuste en efficiënte progressieve politiek. ${ }^{5}$

Op gezag van evolutionair denkende Duitse sociologen als Schäffle en (vooral) Gumplowitz krijgt bij de oudere Ward de rol van strijdende clans in het proces van sociale evolutie meer nadruk dan voorheen. Toch is zijn boodschap al die jaren dezelfde gebleven: alleen spreiding van kennis stelt vooruitgang van de mensheid zeker. Als er al iets ingrijpend veranderd is, dan is het veeleer de omgeving waarin hij die boodschap uitdraagt. of misschien beter gezegd: er heeft zich inmiddels een omgeving, een referentiekader gevormd. Dynamic Sociology werd geschreven voor een anoniem publiek; nu - in 1904 - spreekt Ward voor collega's.

Temidden van de disciplines die zich in St. Louis aan 'de wereld' presenteren, debuteert de sociologie als een zelfstandige wetenschap. Voor jongere sociologen als Small is het een belangrijke gebeurtenis. Sociologie lijkt snel op weg datgene te worden wat het volgens hen zou moeten zijn: een reguliere academische discipline. Eén element ontbreekt nog: een eigen professionele vereniging. Maar in dat tekort wordt snel voorzien. In 1905 komt de American Sociological Saciety voor de eerste maal bijeen.

Wat is er gebeurd in de periode nadat Ward zijn Dynamic Sociology schreef? In de literatuur vinden we twee soorten antwoorden.

\section{Sociale of cognitieve demarcatie}

Sommige auteurs noemen het ontstaan van een sociale band tussen Ward en zijn jongere collega's de belangrijkste verandering die rond de eeuwwisseling plaatsvindt. ${ }^{6}$ In 1883 wordt al wel sociologie bedreven, maar wat vooral ontbreekt is een sociaal netwerk, een gemeenschap van onderzoekers. Van groepsvorming, bij voorbeeld rond een 
tijdschrift of een opleidingsinstituut, is nog geen sprake. In 1904 daarentegen kent men elkaar; er is een sociologische gemeenschap ontstaan. De vestiging van de Amerikaanse sociologie als academische discipline wordt aldus primair beschouwd als een sociaall verschijnsel, als een proces van institutionalisering en professionalisering Cognitieve factoren spelen daarbij een ondergeschikte rol. Obershall noemt het zelfs a striking feature of U.S. sociology (...) that it was institutionalized before it had a distinctive intellectual content, a distinctive method, or even a point of view". ${ }^{7}$

Anderen hebben deze interpretatie bestreden. Het ontbreekt de vroege Amerikaanse sociologie, zo is bij voorbeeld tegen Obershall ingebracht, geenszins aan een eigen gezichtspunt. Afgezien van Sumner delen de eerste sociologen een stijl van denken die men met Fine 'progressief evolutionisme' kan noemen. Vanuit deze tweede benadering wordt niet groepsvorming opgevoerd als de belangrijkste verandering rond de eeuwwisseling, maar het ontstaan van een cognitieve band, een "disciplinaire matrix' zo men wil. ${ }^{8}$

Deze tweede interpretatie kan zich beroepen op het beeld dat de eerste Amerikaanse sociologen zelf van hun vak hadden. Wij vinden allemaal dat de sociologie tot taak heeft de wetten te ontdekken die aan sociale relaties ten grondslag liggen, zegt Small op de eerste bijeenkomst van de American Sociological Society. En; zo vervolgt hij, wij stellen ons ook allemaal op een evolutionair standpunt: leder van ons is op zoek naar de krachten die mensen samenbinden en die de ontwikkeling van samenlevingen bewerkstelligen. Eveneens verschillen we niet van mening over het uiteindelijke doel van deze zoektocht. Het gaat ons er uiteindelijk om de maatschappij op een hoger plan te brengen. 9

Welke weg hier in te slaan? Vanuit het institutionele gezichtspunt van de beroepensociologie kunnen we met Obershall de vestiging van de sociologie beschrijven in termen van het ontstaan van eigen leerstoelen, tijdschriften en leerboeken. De aandacht gaat dan primair uit naar het creëren van een sociale ruimte waarin de nieuwe wetenschap tot ontplooiing kan komen. Vanuit dit gezichtspunt krijgt de vraag hoe de sociologie zich in de Verenigde Staten een plaats op de universiteit wist te verwerven gewoonlijk een tweeledig antwoord: de eerste generatie van academische sociologen in Amerika schiep de institutionele condities waaronder het vak kon gedijen; de tweede generatie, waartoe mensen als Thomas, Park en Chapin behoren, vulde de door hun voorgangers gecreêerde sociale ruimte vervolgens inhoudelijk in.

Dit idee van een gefaseerd proces van vestiging, van een temporele arbeldsdeling, verwoordt zeker een bijzondere trek van de disciplinegeschiedenis van de Amerikaanse sociologie, vooral in vergelijking mel de geschiedenis van het vak in landen als Frankrijk en Duitsland: In deze landen valt de opkomst van de sociologie samen met de produktie van sociologische teksten die door hedendaagse sociologen nog altijd gelezen worden. Is men met Simmel, Weber en Durkheim nog steeds in gesprek, de conversatie met de Amerikaanse grondleggers van het vak is daarentegen reeds lang gestopt. Alleen op het werk van Sumner en Cooley wordt af en toe nog teruggegrepen, maar in het vestigingsproces van de Amerikaanse sociologie als academische discipline spelen zij een marginale rol. Het oeuvre van hen die wel een hoofdrol speelden, maakt daarentegen geen deel meer uit van het sociologische erfgoed.

Deze bijzondere omstandigheid heeft beoefenaren van de disciplinegeschiedenis van de Amerikaanse sociologie ertoe verleid een onderscheid aan te brengen tussen het 
"eigenlijke" begin van de sociologie in de Verenigde Staten (in de jaren twintig wanneer door het werk van Thomas en Park het vak pas echt 'interessant' wordt) en een "oneigenlijk" begin (in de jaren negentig van de $19 \mathrm{e}$ eeuw wanneer de eerste hoogleraren in de sociologie worden benoemd). ${ }^{10}$ Het aanbrengen van deze tweedeling betekent evenwel dat men de historische vraag naar de vestiging van de sociologie verwart met de beoordeling achteraf van de ontwikkeling van het vak. Het probleem met deze vorm van finalisme is dat men onvoldoende recht doet aan de opvattingen van de eerste Amerikaanse sociologen, ook al wijkt hun gezichtspunt nogal af van hun nazaten. Bovendien schuift in deze benadering de vraag naar de achtergrond op welke manier de eerste academische sociologen wetenschappelijke legitimiteit en cultureel gezag probeerden te verwerven. Bij het opeisen daarvan gaat het immers niet slechts om het creëren van institutionele voorwaarden, om het scheppen van een sociale nis. Er dient ook een cognitieve ruimte te worden ingenomen. Het verwerven van academische posities is in dat kader niet voldoende; cultureel gezag dient met cognitieve middelen te worden gelegitimeerd.

Binnen de genoemde alternatieve opvatting worden de grondleggers van de Amerikaanse sociologie niet geportretteerd als louter kwartiermakers van latere generaties sociologen. Wie de vestiging van de sociologie wil begrijpen dient volgens deze richting ruime aandacht te besteden aan de aard van hun ideeën. Want de sociologie kon zich als academische discipline juist profileren omdat die ideeen nauw aansloten bij het progressieve denken dat rond de eeuwwisseling zo invloedrijk werd. Door aldus datgene te benadrukken wat de eerste Amerikaanse sociologen met anderen delen, blijft evenwel ook in dit geval het vernieuwende van hun activiteiten onderbelicht. Voor het verwerven van wetenschappelijke legitimiteit is het immers niet voldoende aansluiting te zoeken bij de 'tijdgeest'; men zal tevens moeten aangeven waarin het eigen vak zich bij voorbeeld van Sociale Wetenschap, Spencers geschiedfilosofie en andere menswetenschappen onderscheidt.

Om inzicht te krijgen in de vestiging van de Amerikaanse sociologie is uiteindelijk ook een combinatie van beide benaderingen onvoldoende. Want auteurs als Obershall en Fine stemmen daarin overeen dat zij de vestiging van de sociologie in de Verenigde Staten te zeer interpreteren als het vanzelfsprekende gevolg van externe ontwikkelingen. $\mathrm{Zij}$ verschillen alleen van mening over het relatieve gewicht dat hierbij aan sociale en cognitieve factoren moet worden toegekend. In beide benaderingen wordt te weinig aandacht geschonken aan de daadwerkelijke constructie van de discipline, aan de handelingen, keuzen en beslissingen die daaraan hebben bijgedragen.

De versie van de sociologische ontstaansgeschiedienis die ik in dit hoofdstuk uiteen zal zetten, wil deze kritiek ondervangen. Daartoe presenteer ik de vestiging van de Amerikaanse sociologie als academische discipline primair als een demarcatiegeschiedenis, als een geschiedenis van het maken van onderscheidingen. Het gaat me daarbij niet alleen om het aanbrengen van sociale onderscheidingen; cognitieve distincties zijn even belangrijk. Zelfs is het zo dat we beide vormen van demarcatie bij het beoefenen van niet-finalistische wetenschapsgeschiedenis eigenlijk niet goed van elkaar kunnen isoleren. Er vormt zich niet eerst een sociale groep van sociologen die zich vervolgens een eigen, cognitieve identiteit aanmeet en evenmin bestaat er eerst zoiets als het sociologische gezichtspunt waaromheen vervolgens een sociaal collectief ontstaat; 
beide ontwikkelingen vinden tegelijkertijd plaats. Deze stelling zal ik nu eerst aan de hand van een exemplarisch voorbeeld illustreren.

\section{Kwartier maken in Chicago}

De naam van Albion W. Small ontbreekt in geen enkel overzichtswerk van de geschiedenis van de sociologie. Hij wordt algemeen gezien als een van de belangrijkste grondleggers van de Amerikaanse tak van het vak, waarvan velen een theologische achtergrond bezitten. ${ }^{11}$ Zo ook Small. Hij volgt een opleiding tot baptisten-dominee, maar laat zich niet beroepen. In plaats daarvan doceert hij enige jaren geschiedenis op Colby en in 1889 wordt Small president van dit traditionele baptistische 'collegè aan de Oostkust. In deze laatste functie begint hij met het verzorgen van cursussen in de sociologie. Drie jaar later verhuist hij naar Chicago om aan de nieuwe, eveneens baptistische, universiteit aldaar directeur te worden van de sociale faculteit. Small blijft deze faculteit leiden tot zijn dood in 1926. Tot dat tijdstip oefent Small eveneens de functie uit van hoofdredacteur van The American Joumal of Sociology, een tijdschrift dat hij in $\mathbf{1 8 9 5}$ heeft opgericht. Dit eerste sociologische tijdschrift in Amerika fungeert van 1905 tot 1927 als officieel orgaan van de American Sociological Society, de vereniging die ook all op Smalls initiatief is gesticht. ${ }^{12}$ De aanstelling van Small blijkt kortom een goede beslissing te zijn geweest van de president van de universiteit van Chicago, William Rainey Harper. Toch is Small niet zijn eerste keus.

De ruime financièle middelen waarover Harper beschikt - grotendeels verstrekt door de baptist en oliemagnaat Rockefeller - stellen hem in staat de universiteit van Chicago in korte tijd uit te bouwen tot hêt onderwijscentrum van het middenwesten. Harper trekt een groot aantal wetenschappers van naam aan; hij biedt hen zowel hogere salarissen als betere onderzoeksfaciliteiten. Maar Harper doet meer. Evenals andere onderwijshervormers uit zijn tijd schrijft hij de moderne universiteit een culturele en opvoedende taak toe. In dat kader roept hij ondermeer een faculteit in het leven die zich zou moeten concentreren op 'het verbeteren van de maatschappij'. Van deze faculteit zal Small directeur worden, maar pas nadat twee mannen van naam voor de functie hebben bedankt.

Harper polst voor het directeurschap in eerste instantie de historicus Herbert Baxter Adams en de politiek econoom Richard T. Ely, beiden hoogleraar aan de Johns Hopkins universiteit. Adams en Ely stonden aan de wieg van respectievelijk de American Historical Association en de American Economical Association en zijn inmiddels uitgegroeid tot figuren met nationale bekendheid. De onderhandelingen mislukken echter, omdat Harper hen bij het benoemen van medewerkers niet de vrije hand wil geven. Small, die door Harper vervolgens wordt aangezocht, is inschikkelijker; anders dan voor Adams en Ely betekent het aanbod voor Small immers een fraaie promotie. ${ }^{13}$

Harper beschouwt de nieuwe faculteit als een 'Department of Social Science' en ook zijn benoemingsbeleid sluit aan bij de traditie van Socialle Wetenschap, een traditie waarin disciplinaire herkomst van ondergeschikt belang is. Naast Small benoemt Harper 
een antropoloog, een deskundige op het gebied van liefdadigheidswerk en een huishoudkundige met interesse in gezondheidsvraagstukken. ${ }^{14}$

Tussen Small en Harper bestaat een grote mate van religieuze en politieke verwantschap ${ }^{15}$, maar op éen gebied is er een duidelijk verschil in oriëntatie. Harper wil enkel Sociale Wetenschap een academisch onderkomen verschaffen; Small daarentegen stelt zich vanaf het begin een ander doel. $\mathrm{Hij}$ wil de sociologie een wetenschappelijke status geven; er een bezigheid van maken waarvoor een universitaire opleiding nodig is en die activiteiten omvat welke aan professionele vereisten voldoen. Als geen ander in het Amerika van zijn tijd probeert hij de sociologie te veranderen van een (filantropische of kosmologische) confessie in een academische professie.

In Smalls ogen is alleen de professionele expert degene die met gezag over sociale kwesties kan spreken: 'Sad as it may be, we are so constituted (...) that we cannot get on very fast or far unless some of us get intelligent. There must be somebody to see things as they are to steer the rest of us.. ${ }^{16}$ Het onderscheid dat Small aanbrengt tussen de enkelingen die zien hoe de dingen zijn en het overige deel van de bevolking, kan moeilijk origineel worden genoemd. Het proces van professionalisering is aan het eind van de $19 \mathrm{e}$ eeuw ook in de Verenigde Staten reeds vergevorderd. Nieuw is echter dat Small het onderscheid van toepassing verklaart op de sociologie. Sociale Wetenschap en Spencers filosofie stonden nog voor een sociale beweging en richtten zich op een breed publiek, kenmerken die bij Ward nog duidelijk terug te vinden zijn. Zijn programma van algemeen populair wetenschappelijk onderwijs heeft een egalitaire strekking. Dergelijk onderwijs zou moeten voorkomen dat een njeuwe elite van wetenschappers de oude elite van priesters aflost. ${ }^{17}$ Maar terwijl Ward zich in Dymamic Sociology afzet tegen elke vorm van intellectueel priesterschap, eist Small een duidelijke taakverdeling op tussen academisch socioloog en leek.

\section{Demarcatie als overlevingsstrategie}

Het verschijnen van de sociologie op het academische toneel is voor verschillende groeperingen aanleiding het vak met kritiek te bestoken. Historici, economen en psychologen betwisten het nut van nog een nieuwe sociale wetenschap. Ook de leden van de oudere American Social Science Association (ASSA) staan skeptisch tegenover de aanspraken van academische sociologen. Deze praktisch georiènteerde beoefenaren van Socialle Wetenschap hebben weinig belangstelling voor abstracte theoretische beschouwingen, een activiteit waaraan de eerste hoogleraren in de sociologie juist een groot gewicht toekennen. Bovendien wordt het academisch aanzien van de sociologie nog eens betwist door een breed scala van publicisten. Sociologie wordt afgeschilderd als een modevak en sommigen zien de opkomst van het vak zelfs als een teken voor het verval van de cultuur. ${ }^{18}$

Small noemt de tijd waarin hij leeft 'the era of sociology"19, maar de introductie van het vak als academische discipline is allesbehalve een vanzelfsprekende kwestie geweest. Zijn bestaansrecht staat ter discussie zolang sociologen in het openbaar nog regelmatig 'freaks' en 'faddist' worden genoemd, andere menswetenschappers hun werk betitelen als 'the residuary legatee of a defunct and discredited philosophy of history' en men zich vanuit literaire hoek afvraagt wat het voor zin heeft sociologen de levensomstandigheden van de armen te laten beschrijven when Dickens and Thackeray have done all that work 
much better than they can hope to do it: ${ }^{20}$ Een academische status dient te worden afgedwongen, zoals Small beseft. Aan die strijd zal hij dan ook veel energie besteden.

Small vecht op meerdere fronten. Hij distantieert zich van Spencers synthetische filosofie; hij probeert de sociologie af te grenzen van andere menswetenschappen; en hij stelt pogingen in het werk zogenoemde amateurs in diskrediet te brengen. Wat hield deze "demarcatiearbeid" ${ }^{21}$ eigenlijk in? Laten we om te beginnen bezien hoe Small een onderscheid probeert aan te brengen tussen echte" sociologen en amateurs "Deze vorm van demarcatiearbeid wordt door Small vooral bedreven in zijn talloze boekbesprekingen. Enkele van zijn langste recensies behandelen de produkten van wat Small Sonntagsreiter' noemt.

\section{Sociologie afbakenen van amateurisme: twee strategieën}

Uit de disciplinegeschiedenis van de sociologie komt Small naar voren als 'a man of real tolerance of viewpoint and true catholicity of interests'. ${ }^{22}$ Toch kent zijn tolerantie duidelijke grenzen. 'Popular education', merkt hij in een van zijn recensies op, 'has produced a multitude of amateurs who have just enough thetorical knack, commonplace information, and conceit of wisdom to afflict reviewers and the public with a flood of superfluous books. This evil is acute in the field of social science'. ${ }^{23}$ Hoe minder zulke boeken met wetenschappelijke pretenties worden gepubliceerd, hoe beter. Small roept zelfs uitgevers op de publikatie van populaire boeken over sociale vraagstukken te staken. ${ }^{24}$ In een tijd dat academische erkenning juist bevochten moest worden, heeft Small geen enkele behoefte aan publikaties die de positie van de sociologie als wetenschap zouden kunnen ondermijnen.

Uiteraard voert Small argumenten aan om boeken van 'Sonntagsreiter' voor onwetenschappelijk te verklaren. $\mathrm{Zij}$ houden zich niet aan "the canons of inductive science" en laten bovendien hun politieke voorkeuren openlijk blijken. Small acht partij kiezen in de strijd tussen arbeid en kapitaal voor een professioneel socioloog uit den boze. Wetenschappelijke objectiviteit vereist volgens hem bovenal politieke onpartijdigheid. ${ }^{25}$ Socialisme, deelt Small zijn lezers dan ook keer op keer mee, is een amateuristische vorm van denken die met sociologie niets van doen heeft.

De grenzen tussen wetenschappelijke en amateuristische sociologie lopen evenwel grilliger dan Small lief is. Zo ziet hij zich geconfronteerd met het feit dat sommige van zijn professionele collega's precies dezelfde fouten maken als de gewraakte 'amateurs'. Ook in hun publikaties worden uitspraken veelal niet door feiten gestaafd. Een boek van Franklin H. Giddings (1855-1931), hoogleraar in de sociologie aan de Universiteit van Columbia te New York, wordt door Small gekarakteriseerd als 'splendid guesswork'. ${ }^{26}$ En in een bespreking van een ander werk van Giddings schrifft hij: "The speculative temper is so dominant in Professor Giddings' work that there are few important passages in the book which critical readers will accept without challenge ${ }^{* 27}$ De Franse vertaling van Gumplowicz' Soziologie und Politik is aanleiding voor een soortgelijke opmerking: "It is true, as the editor claims, that this book is "suggestive". So is Jules Verne*. ${ }^{28}$

Rond de eeuwwisseling bestaat er geen markant verschil in opleiding tussen de gemeenschap van professionele sociologen en de zogenoemde amateurs; tussen 'wij' en 'zij'. De eerste hoogleraren in de sociologie waren tenslotte ook amateurs. Terugblikkend 
is het enige retle onderscheid (daarin heeft Obershall gelijk) sociaal van aard: van de mensen die schreven over maatschappelijke vragstukken waren sommigen aangesteld als socioloog en anderen niet. Vanuit een meer historisch gezichtspunt valt echter op dat met het maken van dit sociale onderscheid tegelijkertijd een cognitieve distinctie wordt aangebracht. Dat gebeurt langs twee wegen.

Een daarvan maakt gebruik van een metafoor die we ook in het werk van Franse sociologische pioniers als Comte en Durkheim terugvinden: de metafoor van de diepte. Onder de wereld van alledag verbergt zich een meer reele sociale wereld, een realiteit die slechts met sociologische middelen te ontsluiten valt. Eeuwenlang hebben intellectuelen alleen oog gehad voor de effecten van sociaal gedrag, waardoor ze niet tot de diepere oorzaken zijn doorgedrongen. Totdat de sociologie op het academische toneel verschijnt, heeft het de mensheid derhalve ontbroken aan het ware zicht op de sociale realiteit.

Small hanteert regelmatig deze metafoor van de diepte in zijn boekbesprekingen. Betreft het het werk van sociologische buitenstaanders dan vinden we oordelen als: $\mathrm{He}$ has built his whole treatment upon a division according to external traits of social actions, instead of discovering the radical principles of actions: ${ }^{29}$ Collega's worden daarentegen geprezen voor hun pogingen door te dringen in voor leken ontoegankelijke en ook onbegrijpelijke gebieden. Niet eén tiende van eên procent van de Amerikaanse bevolking heeft een scherpere blik voor sociale feiten dan collega Ross, meldt Small bij het verschijnen van diens boek Social Control. ${ }^{30}$

Even belangrijk voor het opbouwen van een cognitieve grens tussen amateurs' en de gemeenschap van professionele sociologen is, ten tweede, een vorm van argumentatie die berust op een ondermeer aan Peirce ontleend beeld van wetenschappelijke vooruitgang. Op de lange duur bereiken alle wetenschappen onderling overeenstemming, en, zo voegt Small daar aan toe, overeenstemming binnen een vakgebied is een belangrijke stap op weg naar dat ideaal. Hoewel er binnen de prille sociologische gemeenschap allerlei verschillen van mening bestonden, suggereert Small in zijn demarcatiewerk dat die stap reeds is gezel. Hij gaat ervan uit dat er een grote mate van consensus onder sociologen bestaat en ontleent daaraan een maatstaf voor het beoordelen van nieuwe boeken. $\mathrm{Bij}$ voorbeeld zo: The book is full of indications that the author is not yet sufficiently at home among the sociollogists to give the essentials and the non-essentials of their procedure proportionate attention' ${ }^{31}$ Wanneer iemands denkbeelden niet in overeenstemming zijn met de door sociologen gedeelde inzichten, dan behoeven ze ook niet serieus te worden genomen. Zo opent Small zijn bespreking van een boek onder de titel From Comte to Benjamin Kidd met de constatering dat Kidd door 'de' sociologie niet voor vol wordt aangezien. En hij voegt daar dadelijk aan toe: 'The author's evident assumption to the contrary excludes him from serious attention by the sociologists. Nothing that he can say about the content of sociological thought can have any weight with men who are familiar with the subject'. ${ }^{32}$ Omgekeerd worden publikaties van collega's bijna altijd door Small begroet als bijdragen aan het sociologisch kennisbestand. Kritiek op het werk van collega Giddings bij voorbeeld wordt steeds afgesloten met opmerkingen als: 'That he has not accomplished what his program promised does not prove that he has failed to make a contribution to sociology ${ }^{\mathbf{3 3}}$ 
Woorden van deze strekking dragen ertoe bij cen cognitief domein te creerren voor de sociologie. In Smalls selectieve behandeling van nieuw verschenen boeken wordt een cognitief onderscheid opgebouwd tussen collega's en buitenstaanders, demarcatiearbeid makt van het verschil tussen die beide groepen meer dan alleen een sociaal onderscheid.

Het beroep op het vermogen 'diepere' kennis te verwerven en de proclamatie van 'de" sociologie (er bestaan niet allerlei sociologieën, maar er is cen vakgebied waaraan iedere academische socioloog zijn steentje bijdraagt) zijn twee strategieen die tot doel hebben rivalen hun (intellectueel) gewicht te ontnemen door hen in een geisoleerde positie te plaatsen. Dit isoleren van opponenten (er 'amateurs' van maken, zeg maar) is echter niet altijd mogelijk. Met name dienen de vertegenwoordigers van andere menswetenschappen anders te worden benaderd. Want wie hen tot lichtgewichten bestempelt, zou en passant het collectief waarvan zij deel uitmaken aanvallen. Die confrontatie heeft Small vermeden, in dit geval is het tonen van een zekere tolerantie een betere strategie.

\section{Sociologie afbakenen van andere disciplines: een derde strategie}

Small deelt regelmatig mee dat de sociologie er niet op uit is zich ten koste van andere menswetenschappen een plaats op het academische toneel te veroveren. Maar, zo voegt hij daar aan toe, beoefenaren van de geschiedwetenschap of de economische wetenschap zullen wel moeten beseffen dat zij niet zonder de sociologie kunnen; zonder die wetenschap blijven $z e$ als blinden rondtasten. $O m$ temidden van reeds bestaande menswetenschappen voor de sociologie een cognitieve ruimte te creëren, maakt Small in dit geval gebruik van een derde demarcatiestrategie. Die strategie treffen we vooral aan in zijn talrijke programmatische artikelen.

Na histrici, economen, psychologen, etnologen en politieke wetenschappers betreden sociologen voorlopig als laatsten het academische toneel. Maar wat daar te doen? Zijn alle beschikbare rollen inmiddels niet verdeeld? Opmerkelijk genoeg geeft Small toe dat op het gebied van de feiten het terrein inderdaad verkaveld is: There is no special kind of fact which deserves to be called sociological par excellence in distinction from historical, or ethnological, or economic, or political, or demographic facts. ${ }^{34}$ Maar als sociologen zich niet op eigen feiten kunnen beroepen, waarop dan wel? Smalls antwoord luidt: op de sociaal-historische realiteit als geheel. Sociologie 'confronts real conditions, while the other sciences deal with abstractions". ${ }^{35}$ De geschiedwetenschap, bij voorbeeld, heet bij Small een abstracte wetenschap, omdat zij 'abstraheert' van het geheel van krachten of principes die achter de gebeurtenissen in het verleden schuil gaan. Historische verklaringen, net als economische of psychologische verklaringen, behouden zo een eenzijdig karakter. Doordat een samenhangend kader ontbreekt blijft de 'echte' betekenis van sociaal handelen in nevelen gehuld, tenzij men de hulp van de sociologie inroept. De andere menswetenschappen, zo zegt Small, must go to sociology for a system of categories that will call for the real meanings of social activities. ${ }^{36}$

Dit is geen loze oproep, want Small meent ook over zo'n categorieênsysteem te beschikken. Sociologische reflectie leert ons namelijk dat het handelen wan individuen door een vast aantal basismotieven wordt geleid, zo betoogt hij: 'Every human individual is a more or less highly differentiated demand for satisfactions which may be generalized as health, wealth, sociability, knowledge, beauty, and rightness" ${ }^{37}$ Elke vorm van samen- 
Ieven, zowel nu als in het verleden, is zoals Small het noemt, een gisting van die zes elementaire motieven.

Op grond van deze theorie van zes universele basismotieven valt meer precies aan te geven waarin historici, etnografen of economen tekortschieten. Hun visie op menselijke activiteiten is eenzijdig, omdat ze net doen alsof menselijk gedrag slechts door een of twee motieven worden geleid, of dat categorieensysteem van motieven zelfs helemaal negeren. ${ }^{38}$ Van de reele mens en de fundamentele sociaal-historische realiteit wordt in dat geval dus geabstraheerd.

De drie demarcatiestrategieen die ik heb besproken (het beroep op diepte, het proclameren van consensus binnen "de' sociologie en het presenteren van een categorieensysteem dat de gehele sociale realliteit omvat) dienen de sociologie af te grenzen van amateuristische' beschouwingen over de maatschappij en haar temidden van andere wetenschappen een eigen cognitieve ruimte te verschaffen. Naast deze pogingen het vak een wetenschappelijk aamzien te geven, kunnen we nog een vierde demarcatiestrategie onderscheiden die erop gericht is de nieuwe sociologische discipline te demarqueren van haar pre-disciplinaire verleden.

\section{Sociologie afbakenen van haar voor-geschiedenis: een vierde strategie}

In de Verenigde staten is het begrip 'sociologie' in de laatste decennia van de $19 \mathrm{e}$ eeuw nauw verbonden geraakt met de naam van Herbert Spencer. In de periode tussen 1876 en 1885 verschenen de verschillende delen van zijn monumentale Principles of Sociology, een werk waarover veel Amerikaanse academische sociologen van het eerste uur hebben opgemerkt dat hun eerste kennismaking met de sociologie samenviel met het lezen van dit boek. Spencers beschouwingen maakten grote indruk en zijn voor hun eigen academische loopbaan van beslissend belang geweest, zo lezen we in latere artikelen waarin op het eigen verleden wordt teruggekeken. ${ }^{39}$ Maar de eer die zij Spencer op het einde van hun carriere betonen, verschilt nogal van de houding die velen van hen in het begin van hun academische loopbaan tegenover Spencers werk innemen. 'Spencer's sociology ends precisely where sociology proper should begin', verklaart Small in 1894 in An Introduction to the Study of Society, Amerika's eerste sociologische handboek. ${ }^{40}$

Spencer wordt ondermeer verweten geen oog te hebben voor het door Lester Ward aangebrachte onderscheid tussen natuurlijke en artificięle vooruitgang. Terwijl Spencer meent dat de mensheid zich alleen langs een natuurlijke weg kan ontwikkelen, stellen Small en het merendeel van zijn collega's dat de vervolmaking van de menselijke natuur langs kunstmatige weg kan worden versneld. Hier ligt een taak voor de sociologie die Spencer ten onrechte veronachtzaamt:

Daarnaast moet Spencers poging alle kennis te integreren in én monistisch systeem het ontgelden. Hij maakt alle menswetenschappen dienstbaar aan zijn kosmologie en onderscheidt daardoor te weinig tussen biologische en psychische krachten die aan sociale verschijnselen ten grondslag liggen. Spencer, zo betoogt Small in een programmatisch artikel uit 1901, 'fails to show that there is a place for sociology ${ }^{31}$, daarmee doellend op het feit dat Spencers project niet aansluit bij het inmiddels gegroeide systeem van wetenschappelijke arbeidsdeling. ${ }^{42} \mathrm{Nu}$ was dat Spencers bedoeling ook niet, maar het is well Smalls zorg. Hij dient juist binnen het universitaire bestel een positie voor de sociologie te vinden. Voor hem is sociologie dan ook geen onderdeel meer van 
een filosofische kosmologie en evenmin een vak waarvan de geschiedwetenschap, de economie en de politieke wetenschap slechts onderdelen zijn. Small erkent de zelfstandigheid van deze vakgebieden, maar meent tegelijk dat de sociologie in hun midden een eigen en bijzondere taak te vervullen heeft: zoals gezegd is zij de discipline die de door andere menswetenschappen vergaarde kennis coördineert en integreert tot een reejel beeld van mens en maatschappij.

Small schermt de sociologie af van "amateurs" en demarqueert het vak van reeds gevestigde menswetenschappen en Spencers kosmologische project. Hij is niet de enige die dergelijk demarcatiewerk verricht. Zijn collega Giddings schat het maatschappelijk inzicht van journalisten laag in, noemt de wijze waarop historici en statistici hun feiten ordenen oppervlakkig en presenteert de sociologie als de meest fundamentele menswetenschap, terwijl ook hij van Spencers filosofie afstand probeert te nemen. ${ }^{43} \mathrm{C} . \mathrm{R}$. Henderson, oorspronkelijk een baptisten-dominee en Smalls naaste collega te Chicago ${ }^{44}$, vergelijkt in zijn boek Social Elements (1898) het nieuwe vak met de assemblagearbeid in een uurwerkfabriek. De losse onderdelen van een uurwerk vormen nog geen klok, 'and it is the business of a certain workman to bring all the separate parts into one effective whole' 45 Ten aanzien van door andere wetenschappen geleverd materiaal heeft de socioloog dezelfde taak, want: 'Sociology is a science of survey, synthetic, teaching us to comprehend what special sciences disect, analyse, and treat apart?.46 Alleen de sociologie presenteert het sociale leven zoals het werkelijk is, zo betogen kortom ook Smalls collega's.

In studies naar de geschiedenis van de vroege Amerikaanse sociologie wordt doorgaans veel aandacht besteed aan de theoretische verschillen die tussen Small, Giddings en andere grondleggers hebben bestaan. Daaraan ga ik hier voorbij, te meer daar vanuit die invalshoek de geschiedenis van de vroege Amerikaanse sociologie meestal geheel en al de gestalte aanneemt van een strijd tussen een aantal individuele pioniers en de vraag vergeten raakt hoe het vak zich als discipline identiteit en autoriteit wist te verwerven. In het vervolg van dit hoofdstuk richt ik me meer op de overeenkomsten die achter die theoretische verschillen schuil gaan. In dat verband ga ik eerst wat dieper in op het type 'realiteit' waar Small en zijn collega's in hun demarcatiewerk steeds naar verwijzen.

\section{Evolutionisme en de taal der sociale krachten}

Rond de eeuwwisseling is het spreken in termen van sociale krachten onderdeel van een sociaal-biologisch vocabulaire dat in Amerika door een breed scala van menswetenschappers wordt gehanteerd. De sociologische omgang met dit vocabulaire wordt vooral gekenmerkt door het ontwerpen van classificatieschema's voor deze sociale krachten. Het schema dat Lester Ward in Dynamic Sociology heeft ontwikkeld, wordt voor deze bezigheid het maatgevende voorbeeld. Daarin worden de sociale krachten als volgt gerubriceerd ${ }^{47}$ : 
Essential forces:

Preservative forces:

Positive, gustatory (seeking pleasure)

Negative, protective (avoiding pain)

Reproductive forces:

Direct. The sexual and amative desires

Indirect. Parental and consanguineal affections

Nonessential forces

Aesthetic forces

Emotional (moral) forces

Intellectual forces

Op dit 'exemplar' ontstaan nadien meer dan een dozijn varianten; iedere sociale wetenschapper die zich profilleert als socioloog, komt met een eigen voorstel. Met eén daarvan hebben we zojuist al kennis gemaakt: Smalls theorie van zes universele basismotieven. Small en zijn tijdgenoten kennen een groot belang toe aan dit classificatiewerk, hoe scholastisch dat in onze ogen ook mag lijken. De toenmalige sociologische communis opinio laat zich met een uitspraak van Edward A. Ross (1866-1951) uit 1904 goed typeren: The corner-stone of sociology must be a sound doctrine of the social forces' ${ }^{48}$ Wat brengt hem en zijn collega's tot die conclusie?

Bekijken we om te beginnen het generieke begrip 'sociale kracht". In de omgangstaal verwijst deze samenstelling gewoonlijk naar de een of andere invloed die van personen, tradities of omstandigheden kan uitgaan. De vakbond of de publieke opinie kunnen we in deze alledaagse betekenis een 'sociale kracht' noemen. Zo wordt rond 1900 de term in de Verenigde Staten ook al gebruikt. Maar voor Small en zijn collega's heeft hij een heel andere betekenis. "Sociale krachten' zijn voor deze sociologen universele, met de menselijke natuur gegeven tendensen, wensen, instincten, motieven of interessen die het menselijk gedrag leiden, zowel in individuele als in sociale zin. Zoals deze omschrijving al aangeeft, verenigt het begrip zaken die nadien gescheiden zijn. Biologische kenmerken, psychologische eigenschappen, culturele fenomenen en maatschappelijke ontwikkelingen vallen voor deze sociologen kennelijk in eén en dezelfde categorie.

Waarom hanteert men zo'n onhelder begrip; een begrip dat zowel naar instincten, doeleinden als collectieve idealen verwijst? Disciplinehistoricus Fine schrijft het, zoals veel latere sociologen, in hoofdzaak toe aan onhelder denken: 'Most formulations of the social forces idea reflect considerable confusion and ambiguity regarding the nature and sources of human action'. ${ }^{49}$ Wetenschapsmensen, werkend met begrippen waarvoor geen equivalent in ons vocabulaire bestaat, hoeven echter niet noodzakelijk in verwarring te verkeren. Het is evenzeer mogelijk dat zij de wereld anders indelen dan wij inmiddels gewend zijn te doen.

De taal van de eerste generatie Amerikaanse sociologen is een $19 \mathrm{e}$-eeuws produkt. In deze eeuw nam het historisch bewustzijn niet alleen toe, maar veranderde het ook van karakter. Geschiedschrijving kwam in het teken te staan van de ontwikkeling van de mensheid als geheel, een ontwikkeling die door auteurs als Hegel en Comte werd opgevat als een universeel en doelgericht proces. Voortbouwend op ondermeer de $18 \mathrm{e}$ eeuwse traditie van de historische zoölogie plaatsten auteurs als Spencer en Haeckel op hun beurt de menselijke geschiedenis in het nog bredere verband van de kosmos; sociale evolutie werd bij hen een onderdeel van de kosmische evolutie. In het historisch genre 
dat zo ontstond, vervulden mensen een soortgelijke rol als het dienstmeisje in de $19 \mathrm{e}$ eeuwse roman. Hun handelen kwam nog wel ter sprake; maar voor de structuur van het verhaal was het van ondergeschikt belang. Wereldgeschiedenis werd door andere acteurs gemaakt: de Geest, de Rede, de Wil, de Natuur.

De universele sociale krachten zijn in zekere zin de nakomelingen van deze 19eeeuwse grootheden. $\mathrm{Zij}$ documenteren de groeiende invloed van het natuurwetenschappelijke idioom op de geschiedfilosofie die daardoor een meer psycho-fysische inslag krijgt. Metafysische grootheden als de Rede of de Wil worden ingeruild voor krachten die men in het lichaam en het menselijk bewustzijn lokaliseert, een ontwikkeling die door de invloed van een tweede traditie nog eens wordt versterkt. De opkomst van het spreken over universele sociale krachten duidt namelijk niet alleen op cen verwetenschappelijking van de geschiedfilosofie, het houdt tegelijkertijd ook een historisering in van de ervarings- en passietheorieèn zoals die in de traditie van het Britse empirisme zijn ontwikkeld. Het onderscheid dat Ward makt tussen essentiele en nietessentięle krachten kan langs deze tweede ideeenhistorische lijn bij voorbeeld worden gelezen als een progressief-evolutionaire vertaling van Humes onderscheid tussen instinctieve en secundaire passies.

Voor de generatie van Small, Giddings en Ross wordt de geschiedenis niet alleen door sociale krachten in beweging gezet, dit begrip kleurt ook hun gehele beeld van de geschiedenis. De gebeurtenissen die er in hun versie van de wereld toe doen zijn primair die gebeurtenissen die deze krachten tot leven wekken en al hun historische verhalen berusten steeds op een of andere taxonomie van die krachten. De geschiedenis van de mensheid, zo betoogt bij voorbeeld Ross, begint wanneer animale aandriften worden aangevuld door hogere behoeften die de aanzet vormen tot groepsvorming. In deze associatieve verbanden ontstaan vervolgens krachten van een nieuw type, de sociale waarden, die tenslotte via een selectieproces de overhand krijgen op lagere aandriften en behoeften. Ross vertelt, kortom, de geschiedenis van de mensheid als de opkomst van een serie hièrarchisch geordende krachten. ${ }^{50}$ Als zodanig is zijn verhaal een variant op eerdere vooruitgangsverhalen waarin de geschiedenis van de mensheid wordt verteld als een lange keten van zelftransformaties: niet alleen de omgeving waarin mensen leven verbetert, ook de doelen die zij nastreven krijgen steeds meer niveau.

De veronderstelling dat de menselijke natuur in deze zin een veranderlijk karakter heeft, komt, zo weten wij nu, niet overeen met de darwinistische evolutieleer. Het idee dat karaktertrekken overerfbaar zijn, is ontleend aan Lamarck. Maar aan het begin van de 20 e eeuw was de door Weismann aangezwengelde controverse over de vraag of Darwins leer zich wel of niet met lamarckiaanse inzichten liet verenigen, nog niet geheel en al in het voordeel van Darwin beslist Buitendien is het zeer de vraag of de eerste generatie van academische sociologen de ideeenhistorische erfenis van haar vocabulaire volledig heeft doorgrond. Sporen van het Britse empirisme zijn moeilijk te traceren: naar Locke, Smith of Hume wordt hoogst zelden verwezen. En wat de lijn met de natuurfilosofie betreft, is het raadzaam auteurs als Spencer en Ward te onderscheiden van de latere academische sociologen. Terwijl de eersten nog actief deelnemen an het biologisch debat, volgen Small, Giddings, Ross en Cooley de ontwikkelingen in de levenswetenschappen veel meer op afstand. Ondanks deze verwijdering blijft voor de laatsten de biologische evolutie echter het model voor de sociale evolutie. $Z o$ blijft men de 
sociale evolutie opvatten als een natuurlijk proces, ook al trekt men tegelijkertijd een duidelijke grens tussen de evolutie van samenlevingen en die van organismen. De tweeslachtigheid die latere critici in dit standpunt hebben bespeurd, hebben sociologen als Small en Ross niet opgemerkt. Ze was voor hen onzichtbaar, omdat in hun progressief-evolutionaire vocabulaire niet alleen het begrip "sociale kracht", maar ook woorden als natuur, samenleving en individu een eigen betekenis bezitten. Die betekenis zal ik verduidelijken door stil te staan bij de relaties tussen deze termen (en nog enkelle andere).

\section{Klein sociologisch woordenboek}

Small en zijn collega's gaan er zonder meer van uit dat naarmate een samenlleving zich verder ontwikkelt, $z e$ in een belangrijk opzicht meer 'natuurlijk' wordt. Een hoog ontwikkelde samenleving is beter aangepast aan haar omgeving; ze kent geen rigide structuren, maar staat open voor voortdurende aanpassing en verandering. Kennis, moraal en traditie, tezamen vaak het artificielle of kunstmatige element van een samenleving genoemd, passen zich aan bij een flexibele en op rationele overwegingen gebaseerde sociale orde. Een volgroeide samenleving kent bovendien een meer natuurlijke orde in de zin dat barrieres voor individuele ontwikkeling en sociale mobiliteit zijn weggevallen. De tegenstelling tussen natuurlijk en artificieel heeft in dit vocabulaire derhalve geen absoluut karakter; ze valt bij voorbeeld niet samen met de bekende tegenstelling tussen de (onveranderlijke) natuur en de (veranderbare) sociale orde. Wanneer een samenleving zelfbewuster wordt, wordt ze in de ogen van deze sociologen tevens natuurlijker. In dit verband krijgt ook het begrip voonitgang een specifieke betekenis: maatschappelijke vooruitgang wordt begrepen als een proces dat uiteindelijk uitmondt in het verdwijnen van de tegenstelling tussen natuurlijk en artificieel.

Daarmee is reeds impliciet gezegd dat in dit vocabulaire het woord 'samenleving' eveneens een bijzondere betekenis heeft. Een samenleving opbouwen betekent voor sociologen als Small, Giddings, Ross en Cooley primair: zich verbinden met gelijkgestemden. Een samenleving in deze betekenis lijkt op wat wij een genootschap (of een religieuze gemeente) zouden noemen: een groep verenigde individuen die zich wijden aan een gezamenlijk doel of zich verenigen rond een ideaal. Society is associates associating', zoals een leerboek uit die tijd meldt. ${ }^{51}$ Sluitend is deze vergelijking niet; een genootschap heeft niet dezelfde ontstaansgeschiedenis als een samenleving. De eerste generatie Amerikaanse sociologen weet heel goed dat samenlevingen niet worden opgericht; het betreft, zo wordt juist benadrukt, een natuurlijk proces. In dit geval "natuurlijk' in de zin van toenmalige ecologische inzichten: 'All phenomena inorganic and organic which permanently exist together tend to become accommodated to each other, each yielding what it must to the rest, and establishing a more or less harmonious status quo or modus vivendi. 52

Hoewel professionele sociologen rond 1905 expliciete analogieên met biologische organismen steeds meer gaan vermijden, heeft het organische gezichtspunt zijn sporen nagelaten in hun vocabulaire. Menselijke samenlevingen vormen zich naar analogie van de wijze waarop planten- en dierengemeenschappen ontstaan, zij het dat het proces van wederzijdse aanpassing bij mensen uiteindelijk resulteert in de vorming van een sociale geest, een aantal door het collectief gedeelde doelen en idealen. Deze sociale geest roept 
op zijn beurt organen in het leven die de behoeften van het individu en die van het collectief op elkaar afstemmen: "For the conservation and perfection of social relations and for the realization of ideals, the social mind creates institutions: 53 Instituties als het huwelijk, de economie en de staat dienen zowel de geassocieerde als de associatie als geheel. In dit vocabulaire staat het begrip samenleving dan ook niet tegenover staat, maar tegenover geestloze, ongeordende materie, Constitutief voor een samenleving is haar sociale geest; zij smeedt de losse individuen aaneen, creeert sociale orde en maakt maatschappelijke vooruitgang mogelijk. Maatschappelijke vooruitgang is daarbij min of meer synoniem met de verdere ontwikkeling van deze sociale geest tot een rationele publieke opinie.

Maar kenmerkt de industriële samenleving zich niet door economische en politieke strijd, door sociale en culturele ongelijkheid, door een grote diversiteit van doelen en idealen? Rond de eeuwwisseling beschouwen sociologen in Europa zowel als in Amerika de tijd waarin zij leven als een overgangsperiode: de ontwikkeling van de techniek, de industrialisatie en de toenemende arbeidsdeling hebben de traditionele sociale banden ondermijnd, terwijl nieuwe organen voor het bewerkstelligen van maatschappelijke eenheid nog onvoldoende zijn ontwikkeld. Net als organismen hebben samenlevingen tijd nodig om zich aan snel veranderende omstandigheden aan te passen Europese sociologen als Tönnies en Durkheim benadrukken in dit verband eén breuklijn in de ontwikkeling van de mensheid, die tussen de 'traditionele' en de 'moderne' samenleving. Hun Amerikaanse collega's accentueren daarentegen meer de continuitteit in de geschiedenis: in plaats van een fundamentele wending zien zij louter momenten van stagnatie en versnelling. Tegen de achtergrond van hun ewolutionaire visie worden maatschappelijke problemen en conflicten teruggevoerd op het feit dat gemeenschapszin zich nu eenmaal trager ontwikkelt dan de processen die mensen doen verdelen, zoals arbeidsdeling, industrialisatie en staatsworming Of zoals Ross opmerkt. community groeit minder snel dan society. 54

Dat het idee van de samenleving als een soort genootschap ook voor moderne samenlevingen model blijft staan, is geen idiosyncrasie van Ross. Ook in het werk van Ward, Small, Giddings en Cooley vinden we dit motief. Zo bekritiseert Giddings in 1911 in een toespraak voor de American Sociological Association de stelling van Durkheim dat sociale solidariteit alleen bij primitieve, ongedifferentieerde groepen op eensgezindheid berust. Kijk maar naar Amerika, roept hij. Onze samenleving is complex en zeker niet vrij van problemen, maar, vervolgt Giddings, we have (..) developed a strong national feeling and an intense American loyalty. Notwithstanding the heterogeneity of our population, we acknowledge a certain solidarity of sentiment, and it appears to be fortified and more or less guided by an increasing solidarity of opinion. ${ }^{35}$

In deze ideeën van eenheid en harmonie weerspiegelen zich elementen van een professioneel zelfbeeld dat sociologen rond de eeuwwisseling delen met veel andere wetenschapsbeoefenaren. Hieraan moet echter dadelijk worden toegevoegd dat het binnen het progressief-evolutionaire vocabulaire ook niet goed mogelijk is de relatie tussen individu en samenleving anders te denken dan in termen van loyaliteit en eensgezindheid. Daar zijn drie redenen voor aan te wijzen.

In de eerste plaats verwijst de term individu in de context van dit vocabulaire altijd naar 'geassocieerden'. Daarachter gaat een normatieve aanspraak schuil. Mensen zijn 
slechts in potentie sociale wezens; opvoeding dient ertoe hen te ontwikkelen tot een volwaardig lid van hun samenleving, tot iemand die een nuttige bijdrage levert aan het realiseren van de doelen en idealen van de associatie, kortom tot cen 'citizen'. Het individu is een organische eenheid van krachten, maar die krachten komen slechts tot ontplooiling in een community, in een genootschap of associatie.

Ten rweede verwijzen sociale krachten hier, zoals gezegd, zowel naar subjectieve behoeften als naar collectieve mechanismen. Veranderende omstandigheden doen nieuwe subjectieve behoeften en doeleinden ontstaan die vervolgens via selectie geincorporeerd worden in de structuur van het organisme en aldus tot een objectieve kracht worden. Sociale feiten loskoppelen van psychische feiten, zoals Durkheim doet, is in deze context ondenkbaar: de evolutie van de samenleving en de evolutie van het individu zijn twee kanten van hetzelfde proces. ${ }^{56}$

Ten derde veronderstelt de manier waarop men het idee van maatschappelijke vooruitgang conceptualiseert, noodzakelijkerwijs een harmonieuze band tussen individu en samenleving. Zoals ik al heb aangestipt, wordt vooruitgang geassocieerd met een zich ontplooiende sociale geest. Ervan uitgaande dat individuele en maatschappelijke ontwikkeling elkaars spiegelbeeld zijn, wordt die groel van de social mind" als een soort van volwassenwording gezien.

Hoe en in hoeverre kan een samenleving daadwerkelijk worden opgevoed? Rond de eeuwwisseling wordt daar verschillend over gedacht. Zo kan men de analogie tussen samenleving en individu vanuit een 'cartesiaans' perspectief bezien. Descartes dualisme van lichaam en geest spiegelt zich dan in de kloof tussen massa en elite. Terwijl de elite (de sociale geest) een leervermogen bezit, blijft de massa (het sociale lichaam) altijd een immoreel beest. Dit politieke cartesianisme, een collectief produkt van 19e-eeuwse intellectuelen als Flaubert, Carlyle, Renan en Sprengler, heeft in Amerika weinig weerklank gevonden, ook niet onder sociologen. Niet alleen een verschil in politiek en cultureel klimaat is daarvoor verantwoordelijk, ook een verschil in taall telt hier. In het evolutionaire vocabulaire van de sociale krachten zijn lichaam en geest geen gescheiden werelden. Zowell op het niveau van het individu als op het niveau van het collectief staat niet de tegenstelling 'intellect versus instinct' voorop, maar die tussen het (gehele) organisme en zijn omgeving. Dit conceptuele verschil is niet zonder belang, omdat het een 'inclusieve' opvatting van verandering impliceert. Daarmee bedoel ik dat het voor sociologen als Small en Ross onvoorstelbaar is dat in de loop der geschiedenis wel de moraal verandert, maar niet het menselijk intellect, of dat wel ons sociaal bewustzijn toeneemt, terwijl onze driften gelijk blijven. ${ }^{57}$ Idem dito betreffen ook op sociaal vlak veranderingen per definitie de gehele associatie. In dit opzicht sluit hun vocabulaire politiek-reactionaire standpunten niet uit (door bij voorbeeld socialisten, negers of vrouwen buiten de associatie te plaatsen), maar deze missen de antidemocratische ondertoon die Europese elitetheorieën bezitten.

De gedachte dat naast het individu ook het collectief als geheel actief kan worden opgevoed, leidt op het niveau van het vocabulaire van de vroege Amerikaanse sociologie tot een nauwe relatie tussen de begrippen 'sociale geest' en 'publieke opinie'. De sociale geest van een samenleving verwijst niet naar haar geestelijke elite, maar komt tot uiting in de opinie van het collectief. Omgekeerd wordt 'publieke opinie', door haar geest toe te schrijven, in de Amerikaanse context een positief begrip. De publieke opinie mag dan 
vaak dom en kortzichtig zijn, inherente kenmerken zijn dat niet. Het is mogelijk en ook gewenst haar op te voeden tot een werktuig van de sociale vooruitgang.

Wat zijn de implicaties van deze 'opvoeding"? Het antwoord brengt ons terug bij de relatie tussen 'natuurlijk' en 'artificieel'. Door het intelligent maken van de publieke opinie krijgen artificiële banden tussen mensen weer een natuurlijk karakter. Vooruitgang zal derhalve niet gepaard gaan met een toename van maatschappelijke of politieke conflicten, maar juist eendracht brengen. Zo zal de samenleving, in Amerika althans, weer worden wat ze in essentie is en derhalve ook moet zijn. een gemeenschap, een genootschap van geassocieerden.

Uit de taal waarvan Small en zijn academische medestanders zich bedienen, heb ik begrippen naar voren gehaald als 'sociale kracht', 'natuurlijk", 'artificieel', 'vooruitgang', 'samenleving', 'individu', 'sociale geest' en 'publieke opinie'. Deze begrippen vormen tezamen een metwerk van betekenissen en maken in die zin deel uit van een vocabulaire dat voor deze sociologen verwijst naar een versie van een wereld waarin sociale krachten de realiteit constitueren. Dit vocabulaire heb ik tot nog toe hoofdzakelijk opgevat als een theoretisch instrument voor het begrijpen van maatschappelijke processen. Maar in hun pogingen wetenschappelijke legitimiteit te verwerven, dient dit vocabulaire er tevens toe zich in rivaliteit met andere disciplines te profileren. Daarbij kunnen we onderscheiden tussen de pogingen de sociologie te presenteren als een nieuwe maatschappijwetenschap en de pogingen haar te presenteren als een nieuwe moraalwetenschap. Deze beide praktische functies van het sociologische vocubulaire worden hieronder apart besproken.

\section{De politiek van sociologische theorievorming}

Volgens Small kunnen alle sociale verschijnselen vanuit zes universele basismotieven worden verklaard: ieder mens streeft in principe naar gezondheid, welvaart, samenleven, kennis, schoonheid en rechtvaardigheid. Latere Amerikaanse sociologen hebben van deze in de taal van de sociale krachten opgestelde theorie al snel afstand genomen. Een goed bedoelde maar zeer onbeholpen poging tot sociologische theorievorming, luidt hun oordeel. Door de Ideeen van Small zo te beoordelen, worden ze echter en passant beschouwd als een zuiver theoretisch produkt, als een bijdrage aan 'de' theoric. Voor Small zelf daarentegen heeft zijn motieventheorie ook een praktische functie: de theorie bewijst nuttige diensten bij de strijd tegen concurrerende menswetenschappen. Small beoordeelt zijn theorie zelfs expliciet op deze praktische waarde: "One of the most important strategic positions for sociology in its campaign against the provincialisms of the social sciences is the view-point that real people are constantly engaged in reconciling these six desires, not merely in satisfying one or two of them alone. ${ }^{* 8}$

Binnen de context waarin Small zijn demarcatiewerk verricht, kan zijn handelen niet worden opgesplitst in beschouwende activiteiten enerzijds en praktisch handelen anderzijds. Theoretiseren, recenseren, redigeren, doceren, corresponderen en organiseren zijn voor Small (en voor Giddings en Ross) onderdelen van éen en hetzelfde project; 
een duidelijke scheidslijn tussen cognitieve inspanning en sociale activiteit is ook hier alleen achteraf aan te brengen. Tijdens het maken van geschiedenis interfereren beide bezigheden. Daarmee doel ik niet alleen op het waardegeladen karakter van sociologische theorievorming, maar ook op het feit dat het (theoretisch) begrijpen van de sociale realiteit steeds een praktische component heeft. Verwijzen zet aan tot veranderen.

Deze relatie is al terloops aangeduid bij de bespreking van Smalls demarcatiewerk. Bij zijn pogingen wetenschappelijke legitimiteit voor de sociologie te verwerven, beroept Small zich herhaaldelijk op 'de sociale realiteit' of 'de reele mens'. Deze woorden lijken een objectieve realiteit te representeren waarnaar in de tekst slechts verwezen wordt. In feite roepen ze echter een nieuwe realiteit op, een realiteit die niet alleen door Small wordt gemaakt, maar die als een collectief produkt van de gemeenschap van sociologen kan worden opgevat. Of beter gezegd: tegelijk met het ontstaan van die gemeenschap wordt een sociologische versie van de (sociale) realiteit opgebouwd:

In dit constructieproces worden eerdere versies van die realiteit geherinterpreteerd. Neem bij voorbeeld de realiteit waar de beofenaren van Sociale Wetenschap naar verwezen. Sanborn demarqueerde, zo hebben we gezien, in 1869 Sociale Wetenschap van filantropie met het argument dat beoefenaren van deze nieuwe wetenschap dieper graven dan de weldoeners van voorheen: 'It goes behind the effect to the cause'. De sociologie zet zich nu op een soortgelijke manier tegen de Sociale Wetenschap af.

Giddings, evenals Small een generatie jonger dan Sanborn en White, krijgt in 1894 de gelegenheid een bijeenkomst van de ASSA toe te spreken. Hij windt er weinig doekjes om: aan de manier waarop binnen de ASSA maatschappelijke vraagstukken worden besproken, ontbreekt samenhang en diepgang. Sociale Wetenschap is niet "in touch with reality', want anders dan haar beoefenaren menen, liggen de werkelijke oorzaken voor bijna alle praktische problemen waarmee de samenleving wordt geconfronteerd, ver achter de gebeurtenissen van alledag. Wat we ons dan ook allereerst moeten afvragen, is uit welke fundamentele condities van maatschappelijk leven die problemen ontstaan.

In deze stellingname schuilt wel een risico. Het gedeelde besef tot nog toe verborgen sociale krachten bloot te leggen, mag de communicatie tussen sociologen onderling vergemakkelijken, maar tegelijkertijd neemt het gevaar toe door buitenstaanders niet serieus te worden genomen. Wie de sociologische versie van de wereld geen wetenschappelijke legitimiteit toekent, zal ook sociologen de status van wetenschapsbeoefenaren ontzeggen. Dit is wat Giddings overkomt, nadat hij zijn boodschap in een gezelschap van economen en historici had uilgedragen. In 1903 houdt hij op de landelijke bijeenkomst van de American Economic Association een voordracht onder de titel A theory of social causation'. Giddings verdedigt en illustreert hierin de stelling dat aan alle maatschappelijke instituties alsook aan alle historische gebeurtenissen én causaal mechanisme ten grondslag ligt. De fundamentele processen in de maatschappij moeten worden opgevat als een complex geheel van collectieve reacties op uit de omgeving afkomstige stimuli. ${ }^{59}$ Giddings verwijt bijgevolg vooral historici oppervlakkigheid. Universele waarheden blijven voor hen verborgen, omdat zij weigeren te generaliseren. Een aanwezige historicus antwoordt daarop in de discussie: 'Yes, historians do refuse to try any universal generalization. The sociologist may think it is because we are so near the facts that we 
can't see relationships, we think, of course, that we appreciate better the tremendous complexity of the material, the absolute impossibility in the present condition of human knowledge of capping the life of society with any one formula'. 60 Evenals enkele andere historici gaat de spreker niet in op Giddings theorie over sociale oorzakelijkheid. Ze wordt eenvoudig een vorm van geschiedfilosofie genoemd; daarmee behorend tot een genre waarvan historici zich bij de ontwikkeling van hun professionele identiteit juist willen ontdoen.

Deze associatie met geschiedfilosofie was hoogst onwelkom. Sociologie boort dan wel een diepere realiteit aan, maar uiteraard wil ze niet speculatief heten. Sociologie is wetenschap, is nieuw en beslist geen oude wijn in nieuwe zakken. Dit alleen beklemtonen is echter onvoldoende. Meer dan Giddings beseft Small de noodzaak buitenstaanders ervan te overtuigen dat sociologie wel degelijk naar de wereld van de feiten verwijst, Voordat sociologische uitspraken kunnen refereren - en dus niet als zijnde speculatief in diskrediet te brengen zijn - is het nodig niet-sociologen ervan te overtuigen dat sociologische categorieën en verbanden ook werkelijk bestaan. Daartoe dienen bestaande intuíties te worden ondermijnd, iets wat Small met behulp van talrijke analogieredeneringen heeft geprobeerd te bewerkstelligen. $\mathrm{Zo}$ bij voorbeeld: "In our thought about society most of us are much like the English country gentleman who divided the animal kingdom into "game", "vermin", and "stock". (...) Some of our customary divisions of men are quite as unintelligent. When we talk of the "professional classes" and the "politicians", and the "business men", and the "working men", and the "capitalists", our distinctions are possibly of the "game, vermin, and stock" variety We are probably dealing in superficialities' ${ }^{61}$

Sociologen als Small en Giddings verwijzen naar een versie van de realiteit die niel bestond voordat zij op het academische toneel verschenen. Ze moeten haar zelf vorm en inhoud geven. Dit gebeurt met middelen die wij inmiddels als "retorisch" zijn gaan betitelen. Small noch zijn tijdgenoten hebben echter de bedoeling hun lezers iets voor te spiegelen. Maar zij beseffen wel dat de sociologie, wil ze in haar ontwikkeling als maatschappijwetenschap met rust worden gelaten, zich een publiek dient te verwerven dat haar aanspraken op culturele autoriteit onderschrijt, een publiek dat vertrouwd is gemaakt met wat Small het sociologische 'point of view' noemt. In de eerste jaargangen van The American Joumal of Sociology vinden we dan ook een groot aantal artikelen waarin Small de lezer leert de realiteit vanuit het sociologische standpunt te bezien.

\section{Een kJoof tussen empirie en theorie}

Alles wat tot nog toe over de vroege Amerikaanse sociologie is gezegd, zou de indruk kunnen wekken dat Small zijn tijdschrift voornamelijk heeft gevuld met abstracte, theoretische beschouwingen. Dat is niet het geval. The American Joumal of Sociology (AIS) bevat artikelen waarin over velerlei sociale misstanden wordt bericht. Deze verslaggeving (over zaken als kinderarbeid, de grote kindersterfte in Chicago of de vele arbeidsongevallen in de industrie) kenmerkt zich door een mengeling van morele verontwaardiging en intellectueel optimisme; in dit opzicht sluit ze aan bij de eerdere praktijk van Sociale Wetenschap. Misstanden laten zich oplossen, veronderstelt de redactie, wanneer het denkende deel van de natie maar eenmaal met de blootgelegde feiten bekend is gemaakt. ${ }^{62}$ 
Al benadrukt Small het wetenschappelijke karakter van zijn tijdschrift, veel artikelen in de eerste jaargangen van AJS behoren niettemin tot het genre van de onthullende journalistiek. Dat Small ze toch opneemt, is allereerst een kwestie van tactiek. Ze dienen vooral als lokaas, vertrouwt hij Ward in een brief toe: As I said, or hinted, I wanted to run a lot of articles that can be read easily, by all people of trained intelligence, but I want them to be practically only bait to catch them for more solid and harder reading for which the Joumal is primarily intended". ${ }^{63}$

Maar hoe belangrijk ook, tactische overwegingen bepalen niet uitsluitend Smalls redactiebeleid. Vooral de opname van artikelen met een (ogenschijnlijk) zuiver beschrijvend karakter spoort met het belang dat Small steeds heeft toegekend aan descriptie. Een beginnend sociologiestudent zou er volgens hem goed aan doen zijn onmiddellijke omgeving eerst een jaar lang intensief te observeren. ${ }^{64}$ Daarbij staat Small een beschrijving voor ogen die zich vooral kenmerkt door haar uitputtendheid; de student zou demografische, economische, etnologische, historische en culturele gegevens moeten verzamelen.

Het devies van uitputtende beschrijving, in Nederland bekend geworden onder de naam sociografie, komt voort uit twee bronnen. Evenals Spencer meent Small dat het verzamelen van feiten voorafgaat aan de sociologische interpretatie. Sociologie is immers beslist geen filosofie, maar een empirische wetenschap en men dient, aldus Small, dan ook te waken against the illusion of which Comte was a notorious victim, that data may be interpreted before they are collected. ${ }^{65}$ Bovendien wordt de praktijk van de sociografie ingegeven door de wijze waarop sociologie zich probeert te demarqueren van andere menswetenschappen. Die demarcatie vindt, zoals we zagen, niet plaats door een beroep te doen op specifiek sociologische feiten (en evenmin door te wijzen op een specifiek sociologische methode). Het bestaansrecht van de sociologie wordt verdedigd met het argument dat alleen zij in contact staat met de maatschappelijke realiteit zelf, terwijl andere menswetenschappen niet alle aspecten van het maatschappelijk leven in ogenschouw nemen en derhalve van die realiteit abstraheren. De sociografie biedt deze aanspraak een empirisch fundament.

Toch kent Smalls project voor latere generaties een onbegrijpellijke tegenstrijdigheid. Small en zijn sociologische generatiegenoten hebben, kennistheoretisch gesproken, tegelijkertijd empirist en rationalist willen zijn. Naast het ideaal van minitieuze beschrijving van het maatschappelijk leven staat de zekerheid de fundamentele elementen en mechanismen van dat leven reeds te hebben blootgelegd. De sociologische realiteit lijkt aldus toch in twee delen uiteen te vallen: tussen oppervlakte en diepte, tussen schijn en wezen ontbreekt leder verband. Wie de eerste jaargangen van het AJS doorbladert, ziet die kloof ook treffend geillustreerd. Enerzijds artikelen met duizelingwekkende theoretische schema's, anderzijds talrijke moreel getinte 'journalistieke' artikelen waarin zelfs gebruik wordt gemaakt van foto's.66 Staan deze beide genres inderdaad zo los van elkaar? Of hebben we tot nog toe iets over het hoofd gezien?

\section{Sociologie als ethische wetenschap}

Sociologen als Small paren een stellig geloof in de menselijke vooruitgang aan een diep wantrouwen in hun medemensen. De maatschappij, denken ze in hun sombere ogenblikken, is op drift geraakt. De arbeidsdeling dreigt te ontsporen in een botsing tussen 
kapitaal en arbeid, het politieke bedrijf dreigt te ontaarden in cen strijd tussen belangengroepen; steden dreigen te veranderen in jungles. De omgeving waarin Small dagelijks verkeert, geeft zeker ook aanleiding tot neerslachtigheid. Max Weber, die in 1904 de Verenigde Staten bezocht, schetst er een scherp portret van in een brief aan zijn moeder:

'Chicago is een van de meest onvoorstelbare steden. In enige fraaie villawijken, prachtig gelegen langs het meer, staan merendeels stenen huizen, gebouwd in een uiterst deftige en rustieke stijl. Direct daarachter bevinden zich oude huisjes van hout, net zoals je ze op Helgoland ziet. Daarna komen de huurkazernes van de arbeiders en waanzinnig modderige straten; buiten de villawijken geen plaveisel ofwel miserabele bestrating. Ook in de city tussen de sky-scrapers verkeren de straten nog in een staat die je de haren te berge doet rijzen. Daar komt nog bij dat men "Weichkohle" stookt. Als de hete droge wind uit de zuidwestelijk gelegen woestijn door de straten blaast, dan biedt de stad, vooral als de zon donkergeel ondergaat, een onheilspellende aanblik. Op klaarlichte dag ziet men slechts drie straatblokken ver, - alles is damp, walm, het hele meer is overdekt met een nevel van violet kleurige rook. (...) Bovendien nog een onbegrensde zee van mensen. De city uit reist men onvoorstelbaar lang over de - ik geloof 20 engelse mijl lange Halstedstreet, tussen huizenblokken door met Griekse opschriften, daarna blokken met Chinese cafe's, Poolse reclame-opschriften, Duitse bierhuizen, - tot men bij de stockyards belandt. Zover als vanaf de klokketoren van de firma Armour en $\mathrm{Co}_{\text {. }}$ te zien is, niets anders dan kuddes vee, gebrul, geblaat, eindeloos veel drek. (...) In de stockyards had de boel op stelten gestaan: een verloren staking, massa's Italianen en Negers als stakingsbrekers; dagelijkse schietpartijen met aan beide zijden dozijnen van doden; een tram gekanteld en daarbij een dozijn vrouwen gewond, omdat er een non-union man in had gezeten; aanslagen met dynamiet op de Elevated Railway, waarvan ook inderdaad een wagon ontspoorde en in de rivier stortte: 67

Sociologen als Small, Henderson, Giddings en Ross zoeken de oorzaken van dit soort misère op een globaler niveau dan 'amateurs' als White hadden gedaan. Achter een falend politiek bestuur zien zij vooral morele chaos. ${ }^{68}$ Ze beschouwen het dan ook als hun belangrijkste maatschappelijke opdracht de wankelende morele orde te voorzlen van nieuwe fundamenten.

De strekking van Spencers filosofie is de ethiek een wetenschappelijk fundament te verschaffen. Niettegenstaande de kritiek die men op Spencer heeft, blijven Small en zijn bentgenoten trouw aan die missie. De morele wanorde dient bestreden te worden met een samenhangende visie op het leven, een visie die tegenwoordig slechts de sociologie kan leveren. Sociologen werpen zich kortom op als gidsen die beschikken over overzicht, als mensen die het achter de particuliere belangen verscholen publieke belang weer op de voorgrond zetten.

In complexe en onoverzichtelijke situaties komt een gids goed van pas en het wekt daarom geen verbazing dat Small zijn tijd met een doolhof vergelijkt. Een stelling die ook latere sociologen vaak gebruiken om hun professionele aspiraties kracht bij te zetten, duikt in de geschriften van Small en zijn collega's keer op keer op: de samenleving is zo ingewikkeld geworden dat sociologische analfabeten het overzicht verliezen of reeds verloren hebben. Meer tijdgebonden is echter de ethische ondertoon. In een lang artikel over de betekenis van de sociologie voor de ethiek spreekt Small (in een passage 
die van Durkheim afkomstig had kunnen zijn) over het ethisch bankroet' van de samenleving: 'Speaking generally, our ethical capital consists of a heterogeneous collection of provincial moralities. (...) We have no universal ethical standard to which one class may appeal against another class and get a verdict which the defeated litigant feels bound to accept'.69 Mar zulke universele ethische standaarden zullen er ook niet komen, waarschuwt small, zolang de sociologie voornamelijk skepsis ontmoet: 'There can be no generally recognized ethical standards until we have a generally accepted socio$\log { }^{*}, 70$

Terugkijkend is de aanwezigheid van een kloof tussen beschrijving en theorie net zo opmerkelijk als de afwezigheid van een kloof tussen wetenschap en ethiek, tussen zijn en behoren. Wellicht ligt hier de sleutel voor het genoemde probleem waarom Small c.s. twee geheel verschillende genres beoefenen. Begrijpen we eenmaal warom Small een koppeling legt tussen sociologie en ethiek, dan weten we misschien ook wat we eerder over het hoofd zagen.

In zijn verhandeling over sociollogie en ethiek zet Small om te beginnen de psychologie op haar plaats. Universele ethische standaarden kan die wetenschap ons niet leveren, omdat psychologen louter de vorm van ethische oordelen verhelderen en niet hun inhoud. En juist die inhoud verwijst naar een kijk op het leven, naar een sociologie. Maar die sociologie is meestal subjectief en particulier; ze houdt er geen rekening mee dat individuen of groepen niet op zichzelf staan maar onderdeel zijn van een groter geheel. De wetenschap van de sociologie kijkt verder en onthult vanuit haar omvattend perspectief dat alle handelingen van iedere persoon vanuit dezelfde essentièle motieven kunnen worden verklaard.

Op dit punt aangeland omschrijf Small datgene waar wij allen deel van uitmaken als "het sociale proces". Maar met het aanwijzen van de reeds eerder gememoreerde zes basismotieven is dat proces nog niet volledig gekarakteriseerd. Dat nog een cruciaal aspect ontbreekt, maakt Small aldus duidelijk: 'A further essential of real description of anything is reference of that thing to the end which it is presumed to serve". 7 Veronderstel, vervolgt Small, dat ik een stoel probeer te omschrijven zonder te weten waar hij voor dient. Dan kom ik niet veel verder dan het opsommen van losse elementen. De relaties tussen de onderdelen en hun functies, worden me pas duidelijk wanneer ik op de hoogte ben van het doel van het te beschrijven object. Welnu, wat opgaat voor een stoel, geldt ook voor het sociale proces. De beschrijving daarvan is onvolledig zolang het doel ervan buiten beschouwing blijft.

Het doel van het sociale proces wordt door Small tenslotte met weinig omhaal ten tonele gevoerd. De essentiële basismotieven van waaruit ieders handelen verklaarbaar is, blijken tevens de eenheden te zijn die tijdens de sociale evolutie accumuleren. Het meest algemene doel is daarbij het streven naar 'larger aggregations and juster proportions' van gezondheid, rijkdom, gemeenschapszin, kennis, schoonheid en recht. De universele ethische standaard waar Small naar op zoek was, is daarmee en passant geformuleerd. Al datgene wat met het algemene doel van het sociale proces in overeenstemming is, is goed en dus nastrevenswaardig. Naar Smalls eigen maatstaven worden in deze redenering geen normen uit feiten afgeleid. Van zo'n logische fout is geen sprake omdat doelen hier in de realiteit zelf worden gesitueerd. Wat wij normatieve uitspraken zouden 
noemen, zijn binnen de context van Smalls betoog beschrijvende uitspraken ${ }^{72}$ Sociologie formuleert geen ethische richtlijnen maar legt die louter bloot, meent Small.

Realiseren we ons dat Small pretendeert eigenlijk niets anders te doen dan het leveren van beschrijvingen, zelfs wanneer hij de sociologie een ethische strekking toekent, dan wordt ook duidelijk waarom hij moreel getint sociografisch of journalistiek werk zo problleemloos weet te verbinden met speculatieve schema's en abstracte theoretische beschouwingen. De tegenstelling in de toenmalige sociologische praktijk die ons zo verbaast, is een produkt van onze perceptie. Wij zien een kloof tussen empirie en theorie, omdat het vocabulaire dat Small c.s. hanteren zijn referentie goeddeels verloren heeft; het verwijst niet meer naar wat wij tegenwoordig onder "sociale werkelijkheid" verstaan. De realistische schijn die wij ontwaren, is voor Small en zijn collega's evenwel nog geen illusie. Datgene wat wij nu 'speculatieve' schema's en 'abstracte' of 'ethische' beschouwingen noemen, zijn binnen de toenmalige stijl van sociologiebeoefening even concreet en even deseriptief als de foto's die Small in zijn tijdschrift afdrukt.

\section{Drie sociale praktijken}

Volgens een oud ideaal zou de taal van de wetenschap een transparant medium, een neutrale bemiddelaar tussen ons denken en de wereld buiten ons moeten zijn. Verschillende 20e-eeuwse filosofen, van (de latere) Wittgenstein en Dewey tot Davidson en Rorty, hebben bij dit verlangen echter vraagtekens gezet. Zij hebben gewezen op de onmogelijkheid de taal of het vocabulaire waarin we over onszelf of de wereld spreken, rechtstreeks te vergelijken met de realiteit zelf; buiten die taal om hebben we geen kennis van ons wezenlijk zelf of van de ware werkelijkheid. Maar wanneer zo'n directe vergelijking niet mogelijk is, heeft het ook weinig zin de taal als een soort medium op te vatten. Dan biedt een andere analogie meer perspectief. In plaats van te vragen welke taal 'de ware realiteit' het meest getrouw weerspiegelen kan, kunnen we ons beter afvragen of een taal in een bepaalde context voldoet, of ze ons helpt onze doelen te realiseren. In dit geval beoordelen we taal niet op haar vermogen als een medium te functioneren, maar bezien we haar meer als een stuk gereedschap. Deze wending brengt met zich mee dat we een taal niet kunnen loskoppelen van de context waarin ze wordt gebruikt: wat als het meest geschikte stuk gereedschap geldt, is immers altjjd afhankelijk van wat we ermee willen doen en in welke situatie we ons bevinden. In sommige omstandigheden kun je met een hamer erg veel uitrichten, in andere bitter weinig. Evenzo kent de vraag of het in de wetenschap legitiem is om een bepaald vocabulaire te gebruiken geen eenduidig antwoord. Het hangt af van de praktijken waarin met dat vocabulaire wordt gewerkt.

Voor de wetenschapshistoricus heeft deze laatste notie van taal een methodologische consequentie. Het traceren van een wetenschappelijk vocabulaire en de demarcatiestrategieèn die daarmee verbonden zijn, biedt hem op zichzelf genomen nog geen antwoord op de vraag hoe een wetenschap zich een zekere mate van legitimiteit en autoriteit heeft weten te verwerven. Daarvoor moet in elk geval ook worden onderzocht hoe de leden van een wetenschappelijke gemeenschap of een discipline er in zijn 
gesllaagd hun demarcatiearbeid en hun taal op bepaalde sociale praktijken af te stemmen. In dit geval zijn we, meer precies gezegd, geinteresseerd in de verhouding tussen drie aspecten van wetenschappelijk handelen: hoe heeft men de vorming van een eigen academische identiteit, het vocabulaire dat men hanteert en de praktijken waarop men zich richt, op elkaar kunnen doen aansluiten? Deze vraag beantwoord ik voor de vroege Amerikaanse sociologie in twee stappen. Eerst bezie ik de verhouding tussen identiteit en vocabulaire, er wordt nagegaan of de manier waarop de eerste generatie academische sociologen een eigen identiteit construeren, spoort met de taal die zij gebruiken. Vervolgens bespreek ik hoe deze beide elementen op een aantal praktijken konden worden afgestemd.

\section{Identiteit en vocabulaire}

Sociologen als Small, Giddings en Ross hanteren verschillende strategieën om de sociologie te demarqueren van andere intellectuele activiteiten, zo is eerder betoogd. $\mathrm{Zij}$ menen meer inzicht te hebben in het sociale vraagstuk dan de praktisch-georiènteerde traditie van de Sociale Wetenschap; sociologen zouden de diepere oorzaken van maatschappelijke problemen kunnen blootleggen. Bovendien meent men te beschikken over een breder perspectief dan de vertegenwoordigers van andere menswetenschappen; sociologen zouden de samenhang tussen psychische, economische en politieke verschijnselen kunnen aangeven. Op grond van deze beide competenties menen sociologen tenslotte in staat te zijn de maatschappij op een moreel hoger plan te brengen; in een situatie van morele wanorde kunnen ze optreden als politiek neutrale gidsen. Al deze drie aanspraken leiden er toe dat sociologen zich in feite profileren als deskundigen zonder eigen specialisme.

Deze opstelling lijkt moeilijk te rijmen met het proces van disciplinevorming. De sociologie presenteert zich wel als een discipline, maar niet als een specialisme! Uitgerekend op de eerste bijeenkomst van de American Sociological Society in 1905 typeert Small de sociologie als een 'manier van kijken' die de samenleving als een geheel beschouwt. Wij sociologen, zegt hij, zijn de pleitbezorgers van de wetenschappelijke synthese' die de versplintering van kennis, in de hand gewerkt door de tendens de studie van mens en maatschappij in autonome gebieden op te delen, opvatten als een stap in de richting van wetenschappelijke anarchie. ${ }^{73}$ Disciplinevorming en professionalisering staan hier dus niet in het teken van het streven naar wetenschappelijke specialisatie.

Op grond van mijn bespreking van het progressief-evolutionaire vocabulaire dat sociologen als Small, Giddings en Ross hanteren, kan nu om te beginnen begrijpelijk worden gemaakt waarom deze demarcatiestrategie niet als innerlijk tegenstrijdig wordt aangemerkt. Binnen dit vocabulaire staan de aanspraak op deskundigheid en de aanspraak op alomvattende kennis van de menselijke ervaring namelijk niet tegenover elkaar, maar kunnen zonder meer op elkaar worden afgestemd. Gegeven die taal ontleent de socioloog zijn deskundigheid immers aan het feit dat hij over een theorie van sociale krachten beschikt, een theorie die leert dat iedere concrete gebeurtenis of handeling een samengesteld produkt is van meerdere krachten. Deze veronderstelling, tezamen met de reeds gememoreerde 'inclusieve' opvatting van verandering (alles gaat tegelijk vooruit: intellect, moraal, driftleven, enzovoort) maakt dat Small en zijn geestverwanten niet slechts menen dat in de alledaagse werkelijkheid antropologische, 
economische, politieke, ethische en psychologische verschijnselen met elkaar verbonden zijn. In plaats daarvan verdedigen zij de veel sterkere claim dat de menselijke ervaring ondeelbaar is. Op die grond is het uitgesloten sociologie als een specialisme te begrijpen; zodra ze afstand neemt van haar overkoepelende perspectief, verliest ze niet alleen de samenhang tussen sociale krachten uit het oog, maar ook de (morele) essentie van de menselijke ervaring.

\section{Identiteit en praktijk}

Het idee dat men tegelijkertijd wetenschapper en moreel leider kan zijn, of beter gezegd, dat men aanspraak maakt op moreel leiderschap omdat men wetenschap bedrijft, is rond de eeuwwisseling in de Verenigde Staten geen specifiek sociologische gedachte. Filosofen als Dewey en Royce, historici als Turner en Beard, psychologen als Munsterberg en Stanley Hall, economen als Ely en Veblen stellen zich evenzeer op als maatschappelijke raadslieden. Door de aanspraken die Small en zijn collega's in dit opzicht met hen delen, zijn althans binnen de academische gemeenschap hun pleidooien voor een grotere inbreng van de sociaal-wetenschappelijke expert in de praktische politiek weinig controversieel. Maar deze verwantschap maakt het ondertussen voor sociologen ook moeilijker een eigen culturele rol op te eisen. Dat men daarin toch is geslaagd, hangt samen met de omstandigheid dat ze hun aanspraken op deskundigheid hebben kunnen afstemmen op een aantal specifieke praktijken. Aan het begin van de $20 \mathrm{e}$ eeuw heeft de Amerikaanse sociologie zich in met name drie situaties een legitieme functie kunnen verwerven.

Dat is allereerst de stedelijke publieke cultuur, met Chicago als typerend voorbeeld. Tussen 1892 en 1919 kent Chicago minstens zeventig organisaties voor politieke en sociale hervormingen, die merendeels worden geleid door de leden van de gegoede burgerij (juristen, ondernemers, artsen, dominees, hoogleraren). Ondanks onderlinge verschillen van mening streven al deze hervormers naar een verbreding en versterking van de publieke sfeer. Ze zetten zich in voor meer en beter openbaar onderwijs, meer publieke werken, betere publieke gezondheidszorg, meer publieke parken en bibliotheken. Daarbij ziet men zichzelf niet als een belangengroep naast andere pressiegroepen, maar als de legitieme woordvoerder van het algemene, publieke belang. Niet alleen partijpolitici, maar ook vakbondsleiders en de voorlieden van immigrantenverenigingen worden gewantrouwd: zulke vertegenwoordigers van een bepaald groepsbelang kunnen de publieke zaak slechts schaden. ${ }^{74}$

De sociologie vindt haar belangrijkste bondgenoten binnen dit netwerk van "reform'; organisaties. Het is immers bij uitstek de wetenschap die het leven niet vamuit eén bepaalde gezichtshoek beziet en die ons leert dat de mens niet alleen streeft naar materieel welzijn, maar ook naar sociale, morele, esthetische en intellectuele vooruitgang. En het is tenslotte de wetenschap die ons vanuit een overkoepelend en politiek neutraal perspectief leert wat moreel juist is om te doen.

Een tweede praktijk waarbinnen het mogelijk is als deskundige zonder specialisme te functioneren, wordt gevormd door talrijke organisaties die zich speciaal richten op de educatie en vorming van volwassenen. $Z$ o komt $G$. Vincent, een socioloog die bij Small is gepromoveerd, in 1904 aan het hoofd te staan van de bekendste organisatie op dit gebied: de Chautauqua-beweging. Begonnen als een baptistische zondagsschool is 
'Chautauqua' langzaam uitgegroeid tot Amerika's grootste volksuniversiteit met cursussen op bijna ieder denkbaar gebied. Deze activiteiten staan in het teken van een ideal dat nauw bij het sociologische project aansluit. Omdat de Verenigde Staten een democratische natie is, is sociale vooruitgang pas goed mogelijk wanneer elk lid van deze samenleving leert inzien dat collectieve interessen voorrang hebben op persoonlijke aandriften, zo meent de leiding van Chautauqua. Educatie en vorming in Chautauqua spreken, sociologisch geformuleerd, de hogere sociale krachten aan; ze stimuleren de volwassenwording van de publieke opinie. ${ }^{75}$

Een derde praktijk waar sociologen aan het begin van de $20 \mathrm{e}$ eeuw kunnen gedijen, bieden de vaak pas opgerichte staatsuniversiteiten in het middenwesten van Amerika. Terwijl particuliere universiteiten als die van Chicago en Columbia georienteerd zijn op de stad, staan onderwijs en onderzoek hier sterk in het teken van 'de verheffing van het platteland". Voorop staat het ontwikkelen en verbreiden van voor de landbouwgemeenschap nuttige kennis. De mensen in het westen, schrijft de journalist Lincoln Steffens in een reportage over de universiteit van Wisconsin, zijn niet geînteresseerd in de groei van zuivere kennis; they wanted knowledge to be sought and taught in its relation to life and the needs of men. Consequently colleges, not only of law and medicine, but of engineering and agriculture, were established at the Western state universities almost from the beginning; and courses in business or commerce and many other "practical lines" have been added" 76

Binnen dit op de praktijk gerichte onderwijsklimaat lijkt men definitief afstand te hebben genomen van het oude college-ideaal van karaktervorming. Toch is dat niet helemaal waar. De studenten worden weliswaar niet meer onderwezen in 'moral philosophy", maar daar komt iets anders voor in de plaats: ze worden in staat gesteld facultatieve cursussen in de sociologie te volgen. En van hen die dit onderwijs verzorgen, wordt niet gevraagd gespecialiseerd, toegepast of praktijkgericht onderzoek te verrichten. Integendeel, het is hun taak ervoor te zorgen dat de studenten niet alleen intelligent farmers' worden, maar ook 'intelligent voters' ${ }^{77}$ Het sociologieonderwijs, verklaart de sinds 1904 aan de universiteit van Wisconsin verbonden Ross tegenover Steffens, heeft tot doel to qualify the student to play an intelligent part as citizen by showing which forces are to be restrained, which guided, which stimulated". ${ }^{78}$ Maar daartoe is de docent uiteraard slechts in staat wanneer hij beschikt over datgene wat Ross hier stilzwijgend veronderstelt: "a sound doctrine of social forces?"

Binnen de stedelijke publieke cultuur, aan instituten voor volwasseneneducatie en op staatsuniversiteiten op het platteland; steeds zijn sociologen om dezelfde redenen binnen deze sociale praktijken actief. $\mathrm{Zij}$ proberen bij te dragen aan de vorming van een nieuw type van 'public men', een type dat geen particulier belang maar de publieke zaak vertegenwoordigt en dat aldus de publieke discussie zowel moreel als intellectueel op een hoger plan kan brengen.

Binnen al deze drie praktijken liggen bovendien de academische demarcatie en de politieke inzet van de sociologie in elkaars verlengde: het streven naar sociaal-wetenschappelijke synthese sluit hier aan op het streven naar maatschappelijke eenheid en harmonie. In een tijd dat de intellectuele cultuur haar eenheid dreigt te verliezen en plaats lijkt te maken voor talloze specialismen, in een tijd bovendien dat de politieke 
cultuur lijkt te verbrokkelen en in een stel elkaar bestrijdende massabewegingen uiteen dreigt te vallen, presenteen de sociologie zich binnen deze lokale settingen als een onpartijdige wetenschap. Deze discipline stelt zich boven de nieuwe specialismen en ook boven politieke organisaties die maatschappelijke deelbelangen vertegenwoordigen. Op grond van deze identiteit verwerft de sociologie in alle drie de praktijken cultureel gezag: als geen andere discipline biedt ze het hoopvolle perspectief dat de versnippering van wetenschap en cultuur kan worden tegengegaan door de publieke opinie op een hoger plan te brengen. 
Noten behorende bij hoofdstuk III

1. Churgerman (1965). Zie voor een beknopt overzicht van Wards carriere: Pfautz (1968).

2. De briefwisseling tussen Small en Ward is in de jaren dertig gepubliceerd in het tijdschrift Social Forces. Zie Stern (1932/1937).

3. Ward, vol. I (1883): 22.

4. Ibid: 25 .

5. De lezing van Ward is afgedrukt in deel vijf van Rogers (1905/1907).

6. Zie b.v. A. Obershall, "The institutionalisation of American sociology", in: Obershall (1972): 187-251; L.A. Coser, 'American Trends", in: Bottomore/Nisbet (1978): 287 320.

7. Obershall, op.cit.: 189.

8. Zie b.v. Fine (1979) en Hinkle (1980).

9. Small, (1906).

10. Zie b.v. Bulmer (1984) en Faris (1967).

11. Voor een poging de opvattingen van de vroege Amerikaanse sociologen voornamelijk vanuit hun geboortemilieu te verklaren, zie Hinkle/Hinkle (1954). Dibble merkt over deze poging terecht op: "It is by no means clear what conclusions we can draw from the predominance of clergymen and the sons of clergymen among the founders of American sociology. This predominance does not necessarily mean that sociology was an especially clerical discipline or was especially imbued with religiousness, as compared with other academic disciplines'. In: Dibble (1975): 223. In dit verband kan verwezen worden naar een in 1925 gehouden enquete warin alle personen die voorkwamen in de 1922-1923 editie van Who's who in America naar hun ouderlijk milieu werd gevraagd. Het bleek dat het predikantenmilieu over de gehele linie overgerepresenteerd was. Zie AJS, 30 (1925): $551-557$.

12. Zie voor Smalls intellectuele biografie: Christakes (1978); Dibble (1975); Herbst (1959).

13. Small was dan wel president van een College, maar dat was maar een kleine instelling en had bovendien geen wetenschappelijk aanzien. Het hoogleraarschap aan een grote universiteit gaf meer prestige en werd bovendien beter betald.

14. Over de oprichting van de sociale faculteit in Chicago zie Diner (1975); Storr (1966).

15. Beiden zijn in politiek opzicht verlichte conservatieven, maar huldigen op religieus gebied voor hun tijd progressieve opvattingen. Het evangelie had voor hen vooral een sociale boodschap en ook houden ze alle twee de wetenschap voor een activiteit waarop religie geen invloed dient uit te oefenen. Vgl. Storr (1966).

16. Small (1903a): 471 .

17. Ward, vol. I, (1883): 19. Ward hoopt nog op een algehele diffusie van kennis. Small is meer de wetenschapsman die nog wel erkennen wil dat "it is an affront to omniscient democracy to intimate that every man is not as competent a specialist as any man upon such a familiar subject as human society", maar daar toch dadelijk aan toevoegt: 'Nevertheless, it will be necessary for a good while to come that men who are actually advancing knowledge shall talk to each other a great deal in language that says little or nothing to the layman'. In: Small (1903a): 475 .

18. Een kleine bloemlezing. "The distinguished president of an eastern college took occasion, in an adress before leading Chicago citizens, to associate the name "sociologist" with the terms "freaks" and "faddists," and he is reported to have said that sociology seemed to him to have nothing to do except to gather up what is left after political science and economics have done all that is important with the facts of society." (Small 
in: $A J S, 8: 468$ ). Een hoogleraar Engels vraagt zich af: What is the use of sending out students of sociology to observe the conditions of life among the poor, when Dickens and Thackeray have done all that work much better than they can hope to do 'It?' (Gecit. in Howerth, 1894/1895: 261). Verwijzend naar meningsverschillen tussen sociologen schrijft de redacteur van The Nation: "Sociology no more demonstrates its claim to existence as a science than astronomy would if we found some astronomers insisting that the sun went around the earth and others contending that the earth went around the sun'. (The Nation, 60, 1893: 351). Drie jaar later, in hetzelfde politieke weekblad, wordt gezegd: 'Those who have perused what philosophers have heretofore offered the world under the title "sociology", must have been frequently tempted to repeat the question which Kant so often put concerning metaphysics: How is it anyway possible?' (The Nation, 63, 1896: 92). H:H. Powers, econoom en bestuurslid van de ASSA, schrijft over de sociologische oriêntatie op de biologie: To re-clothe the commonplaces of life with a fantastic terminology borrowed from a different science, and based on somewhat gratuitous analogies, will not make them the less commonplace'. (In: Annals of the American Academy, vol. V (1894-1895): 774). Tijdens een bijeenkomst van de American Economic Association wordt na een speech van de socioloog Giddings door een toehoorder opgemerkt: 'Some years ago at a meeting of this kind, if $\mathbb{I}$ remember rightly, a daring speaker told the sociologists that their "science" was only the "residuary legatee of a defunct and discredited philosophy of history." And in all seriousness I ask, what is sociology but an attempt to build a new philosophy of history, - a philosophy transformed by the new conceptions of physical science?' (In: Publications of the American Economic Association, vol. V (1904): 442). In zijn artikel 'The relations of economics to sociology' betoogt de econoom S.N. Patten dat 'sociologists have no right to stake off for themselves a portion of the field of social science without consulting the economists: (In: Annals of the American Academy, vol. V (1894-1895): 583).

19. Het openingsartikel van het eerste nummer van AJS draagt deze triomfantelijke titel Zie Small (1895).

20. Zie noot 18.

21. De term 'demarcatiearbeid' ontleen ik aan de wetenschapssocioloog T.F. Gleryn. Er wordt mee aangeduid dat onderscheidingen tussen disciplines of, op een algemener niveau, tussen wetenschap en niet-wetenschap niet van nature gegeven zijn, maar door de betrokkenen steeds opnieuw moeten worden aangebracht. Demarcatie, ic. het aanbrengen van grenzen, is geen louter theoretische, wetenschapsfilosofische kwestie; het is veeleer een praktische activiteit, een integraal onderdeel van het dagelijkse wetenschappelijke werk. Gieryn (1983): 781-795. Zie ook hoofdstuk VII.

22. Barnes (1948): 789.

23. In: $A J S$, 9: 583.

24. 'Publishers would deserve better of the public if they would consider more seriously the ethical quality of their conduct when they aid and abet half-fledged thinkers in producing books for half-fledged readers'. In: AJS, 7: 847-848.

25. Smalls denken is op dit punt verwant aan dat van Gustav Schmoller, door wie hij ook in andere opzichten beinvloed is. Zie hoofdstuk IV.

26. In: $A J S$, 3: 111.

27. In: $A J S, 4: 551$.

28. In: $A J S, 4: 105$.

29. In: $A J S, 1: 492$.

30. In: $A J S, 9: 576-577$.

31. In: $A J S, 2: 307$.

32. In: AJS, 5: 123.

33. In: AJS, 2: 288.

34. Small (1898): 166.

35. Ibid.: 166 . 
36. In: AJS, 7: 280. Elders vangt Small de taakverdeling tussen sociologie en geschiedwetenschap in dit juridisch beeld: "The process which the sociologist calls for (...) is to the historian's task somewhat as the public prosecutor's is to that of the various detectives who work up evidence on a case? AJS, $3 ; 162$.

37. Small (1903b): 16. De theorie van de zes motieven oftewel 'interests' wordt door Small uitgewerkt in Small (1905).

38. They have treated persons as tough they were variations of one or two of these interests.' In: Small (1903b): 16.

39. Zo schrijft Cooley in 1920: 'I imagine that nearly all of us who took up sociology between 1870, say, and 1890 did so at the instigation of Spencer. In: Cooley (1920): 129. Vgl. ook Small (1916).

40. Small and Vincent (1894): 43.

41. Small (1900): 44. Vgl ook Small (1906a).

42. In zijn synthetische filosofie brengt Spencer ondermeer een onderscheid aan tussen organische en superorganische evolutie. Organische evolutie betreft de groei en neergang van individuele soorten. Wie deze vorm van evolutie bestudeert, richt zich op de interacties van eén bepaalde soort met organismen van een andere soort en op alle produkten en processen die uit deze interactie met de 'omgeving' voortkomen. Superorganische evolutie daarentegen betreft alle produkten en processen die voortkomen uit gecoördineerde interacties tussen organismen van én en dezelfde soort. Organische evolutie is het onderwerp van de biologie en (wanneer het om de menselijke soort gaat) de psychologie; superorganische evolutie is het onderwerp van de sociologie (een studie die zich uitstrekt van bijen- en mierenkolonies tot politieke instituties). Binnen dit classificatieschema wortelen superorganische fenomenen in organische fenomenen (bij voorbeeld: in interactie met de omgeving ontwikkelt de menselijke soort gevoelens en uit die gevoelens komen vervolgens superorganische produkten voort als de religie of de staat); de nadruk valt dus op het onderscheid tussen organisch en superorganisch, niet op de tegenstelling tussen mens en natuur. Dit tweede onderscheid komt bij de Amerikaanse sociologen meer voorop te staan. De biologie wordt in de verklaring van menselijk samenleven naar de achtergrond gedrongen ten gunste van de psychologie; een ontwikkeling die gelijk op gaat met het ontstaan van een grens tussen 'biologische' sociologie (planten- en dierensociologie) en de 'elgenlijke' sociologie, twee vormen van sociologie die bij Spencer niet principieel gescheiden zijn. Vgl. Spencer (1876).

43. Anders dan Small meent Giddings dat er eén fundamenteel principe ten grondslag ligt aan de oorsprong en ontwikkeling van de samenleving. Het betreft volgens hem cen mentaal verschijnsel dat hij consciousness of kind doopt. Het houdt in dat "society, conceived in terms of its fundamental process, may be regarded as a complex aggregate of agreeing responses to certain stimuli that act upon many men in like ways:. (Giddings (1896): 23.) Giddings ontleent aan de fysiologische associatiepsychologie van Wundt en Fechner de gedachte dat stimuli uit de externe wereld ons aanzetten tot hersenactiviteit waarop interne, mentale processen reageren. Volgens deze psychologen lopen fysiologische en psychologische processen parallel aan elkaar zonder dat er evenwel een directe causale relatie tussen beide niveaus bestaat. Wie als socioloog op deze inzichten door redeneert, zo meent Giddings, laat zowel het 'biologisme' van Spencer als het 'idealisme' van Hegel achter zich. Zijn versie van de sociale evolutie ziet er dan als volgt uit: de samenleving is opgebouwd uit de interacties tussen individuen en dat zijn tegelijkertijd fysische en mentale processen. De stimuli die daarbij een gedeelde respons oproepen (niet: veroorzaken) zijn van tweeerrlei aard. Allereerst zijn er primaire stimuli, direct afkomstig uit de externe omgeving. Zij zorgen ervoor dat parallel aan een uniforme natuurlijke omgeving een homogene samenleving ontstaat en parallel aan een meer geschakeerde omgeving (niet alleen landbouwgronden b.v.) een meer heterogeen samengestelde samenleving. Dit verhaal geeft Giddings vervolgens toch een - onbedoeld idealistische wending. Vanaf het moment namelijk dat er hogere samenlevingswormen gaan ontstaan, evolueren zich tevens een nieuw soort stimuli: 'These new and higher 
stimuli are ideals, and it is these that presently become a factor of chief importance in the higher forms of social causation'. (Giddings (1904): 163.) Deze belangrijkste secun. daire stimuli zijn het ideaal van eenheid, van vrijheid en van gelijkheid. Tegen de achtergrond van deze theorie wordt historici en statistici verweten slechts te werken met de simpele indelingscriteria van ruimte en tijd. Ecomomen wordt voorgehouden geen aandacht te hebben voor de richtinggevende idealen waardoor hogere vormen van sociale evolutie worden geleid. Vgl. Giddings' debat met de econoom Patten in Annals of the Academy of Political and Social Science, 5, 1894-1895.

44. Alhoewel Small, als directeur, meer landelijke bekendheid verwierf, had Henderson binnen de universiteit meer invloed. Henderson (die niet moet worden verward met de leermeester van T. Parsons, LJ. Henderson) werd door Harper op grond van zijn deskundigheid op het gebied van liefdadigheidswerk benoemd tot hoogleraar in de praktische sociologie. Maar tevens kreeg hij de functie van universiteitskapelaan toebedeeld - in die tijd een belangrijke positie. Henderson was tot zijn dood in 1915 een belangrijk man binnen de baptistische gemeenschap en heeft, anders dan Small, tal van publieke functies bekleed $\mathrm{Zo}$ is hij ondermeer president geweest van de "United Charities of Chicago', van de 'Chicago Society for Social Hygiene' en van de National Conference of Charities and Correction', een uit de schoot van de ASSA geboren organisatie. Henderson beschouwde sociologie als een sine qua non voor pastoraal werk. To assist us in the difficult task of adjustment to new situations', schreef hij in 1899 , 'God has providentially wrought out for us the social sciences and placed them at our disposal." (Gecit. door S.J. Diner, op. cit.: 524).

45. Henderson (1898): 8.

46. Ibid: 1. Vgl. ook Henderson (1901).

47. Ward, (1883), vol. I: 472 .

48. Ross (1903-1904): 548 .

49. Fine, (1979): 109.

50. Een passage uit Ross' Social Control, het boek dat Small zo prees, kan deze vertelstructuur illustreren: "Civilization is not simply the progress of the arts, it is also the growth of wants in number and variety and the shifting of the accent from type to type. Food, drink, shelter, sex make up the animal group of wants. To this are added in the higher mamals curiosity and the desire for play and for companionship. Early man begins to be urged on by love of colours, of ornament, of noise, of rhythmic action in unison (dancing), by desires for festivity, converse, collective excitement, and social esteem. (...) Now the development of wants has been hastened by a development of social values. The ascent of the individual, in its later stages especially, has been assisted and presided over by society. Whence comes that mounting desire which gives us moral civilization? (...) Was it Isaiah who enamoured humanity of justice, Eschylus who charmed it with heroic duty, Dante who made purity precious, Petrarch who taught men how to love, Thomas a Kempis who made the spiritual life inviting, Goethe who gave self-culture supreme value? Certainly they reached a helping hand to the mounting human spirit. (...) But apart from the initiatives of great men we can detect in mere association certain forces of uplift. (...) There is set in circulation a mass of beliefs and desires, which, as they do not exist in any individual mind, might (...) be termed the contents of the social mind. Now this mass of heterogeneous materials does not form an amalgam, but is constantly subjected to a process of selection which results in the disappearance of those suggestions and ideas which are felt to be unfavorable to the social welfare, and the survival and vogue of those which are felt to comport with this welfare'. Ross (1901): 325-327.

51. Geciteerd in Fine (1979): 78.

52. Ibid.: 79.

53. Giddings (1897): 33. 
54. Ross (1901): 435. Dit motief van gestage aanpassing aan zich snel wijzigende omstandigheden krijgt in het Amerikaanse vocabulaire van de sociale krachten een specifieke inhoud. Zo conceptualiseert Durkheim de overgang van gemeenschap naar samenleving in dichotome termen. Tussen de conscience collective van vroeger en de conscience collective van de toekomst ligt een cesuur, en wel in drie opzichten. Ten eerste verandert de sociale cohesie van type. Mechanische solidariteit wordt door organische solidariteit vervangen, hetgeen zeggen wil dat in de toekomst de maatschappelijke eenheid niet langer gefundeerd is op eenheid van opinie, maar op wederzijdse afhankelijkheid. Ten tweede zal het collectieve bewustzijn daarmee niet verdwijnen (ook moderne samenlevingen kennen een morele orde), maar krijgt het een inhoud die radicaal verschilt van het collectieve bewustzijn van primitieve, homogene gemeenschappen. Ten derde is het individuele bewustzijn in prehistorische samenlevingen slechts een afspiegeling van het collectieve bewustzijn, maar in hoog ontwikkelde samenlevingen krijgen beide zelfstandigheid ten opzichte van elkaar. Van zo'n driedubbele dichotomie tussen vroeger en nu is bij voorbeeld bij Ross geen sprake. De verzwakking van lokale gemeenschapsbanden, zo redeneert hij, gaat niet alleen gepaard met opkomst van geloofsgenootschappen, beroepsgroepen en sociale klassen. Dit soort nieuwe groepen zijn alleen op het welzijn van de eigen leden gericht en verzwakken derhälve de sociale cohesie in de samenleving als geheel. Dat de moderne samenleving toch niet uiteen valt, komt omdat not all the new communities are of this narrow gauge Certain broadgauge, inclusive communities are growing up. The famous old groups - the Semitic "tribe", the Greek "city", the Teutonic "kindred", the mediaeval "town", the New England "settlement" - were small; but now we see growing up a civic, metropolitan, national, or even racial communion binding men into mammoth aggregates'. (Ross (1901): 434-435.) Het meest aanzienlijke produkt van de opkomst van zulke nieuwe inclusieve gemeenschappen' is evenwel de natie, stelt Ross. Vroeger, toen eensgezindheid lokaal van aard was, vielen de grenzen van de gemeenschap niet samen met die van de staat. De staat was een machtsorganisatie, geen genootschap van eensgezinde burgers. In de $19 \mathrm{e}$ eeuw is echter ook op het politieke vlak de reikwijdte van het saamhorigheidsgevoel toegenomen: 'Since the Napoleontic era those liberal men who hate coercion have found no surer means of purging brute force out of government than to rivise frontiers and make the boundaries of the state coincide with those of the nation'. (Ross 1901: 435.) Voor Ross' intellectuele biografie, zie Weinberg (1972).

55. Giddings (1912): 5 .

56. De taal der sociale krachten maakt het daarentegen wel mogelijk de ontwikkeling van een samenleving op te vatten als de genese van een ras. Of misschien is het juister te zeggen dat het begrip ras in dit vocabulaire verwijst naar wat we tegenwoordig een cultuur zouden noemen. Zo worden de verschillen tussen de blanke en zwarte cultuur in Amerika niet toegeschreven aan het feit dat negers van nature dommer zouden zijn, maar aan de omstandigheid dat hun beider samenlevingen zich op een verschillend niveau van evolutie bevinden. Doordat hieraan de stilzwijgende veronderstelling wordt toegevoegd dat de geestelijke capaciteiten van geassocieerden een afspiegeling vormen van het niveau van een associatie als geheel, ligt het voor de hand de oorsprong van culturele en maatschappelijke variatie te zoeken in de meer of minder snelle ontwikkeling van raskenmerken. Hierbij dient wel te worden aangetekend dat de taal der sociale krachten ruimte laat voor verschillende politieke standpunten. Ross en Giddings bij voorbeeld zijn sterke voorstanders van segregatie: vermenging van rassen zou de sociale evolutie doen stagneren. Maar anderen, zoals Small en Cooley, verwerpen zo'n expliciet racistische politiek. Vgl. Vidich and Lyman (1985).

57. The human lot is a riddle production of a progressively fitter physical, mental, and moral human nature', zegt Small op een sociologische conferentie waarvan de motulen zijn afgedrukt in $A J S, 6$ (1900-1901): 160.

58. Small (1903b): 17 ; mijn curs.

59. Vgl. noot 43 . 
60. Publication of the American Economic Association, Third Series, vol. V (1904): 197. De spreker is W.M. West, een generatiegenoot van Giddings en hoogleraar geschiedenis aan de universiteit van Minnesota.

61. Small (1898): 148-149.

62. Zo eindigt een treurig stemmend artikel over sweat-shops (kleine werkplaatsen waarin op contractbasis kleding of schoenen worden gemaakt) zonnig: 'I bellieve the sweat-shop evil could eradicated if thinking people would lend their aid". MacLean (19013): 309.

63. 'The Letters of Albion W. Small to Lester F. Ward', in: Social Forces, vol. XII (1933): 173.

64. Small, Seminar Notes, in: AJS, 1: 238.

65. Ibid., in: AJS, 1: 196.

66. Een artikel over de sociale functie van de 'saloon' bij voorbeeld is met zes foto's van interieurs verluchtigd. Zie AJS, 3 (1897): 1-12.

67. Gecit. in Marianne Weber (1926): 298-299.

68. Zie b.v. Ross (1907).

69. Small (1903b): 5-6.

70. Ibid: 8. Vgl. ook Vincent (1897).

71. Ibid: 131 .

72. Macintyre's stelling dat in de moderne tijd het teleologische fundament onder de ethiek wegvalt, gaat in elk geval voor de Amerikaanse sociologie niet op. Vgl. Macintyre (1981).

73. Small (1906b): 69.

74. Zie Carey (1975), Diner (1980). Vgl. ook Small (1897).

75. Zie Morrison (1974).

76. Steffens (1909): 352. Vgl. Curti and Carstensen (1949).

77. Ibid.: 354-355.

78. Ibid: 363 .

79. Zie noot 48. 
ta:

$4+40$ क

s.t.

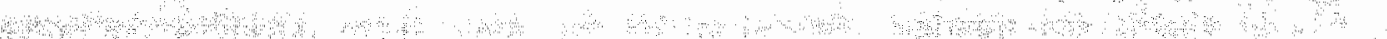

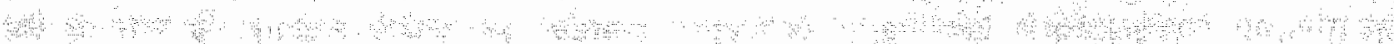

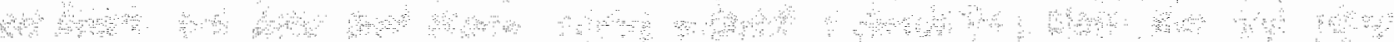
a

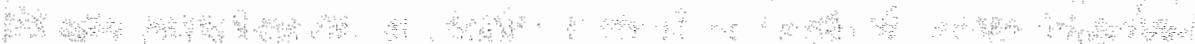

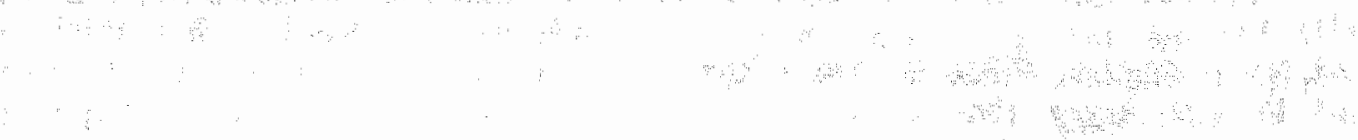

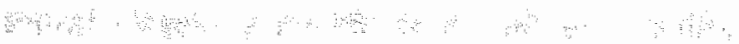

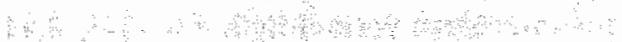

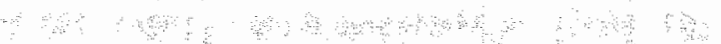

कि

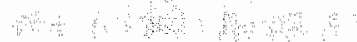

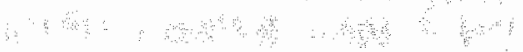

.

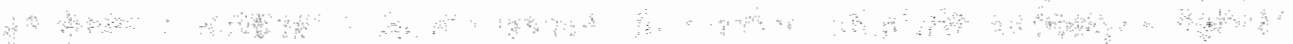

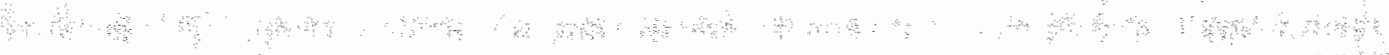

: मलिख क्ष

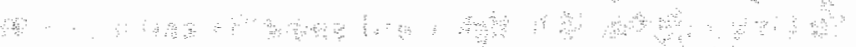
Has : t के s. 


\title{
ONPARTIJDIGE OF WAARDEVRIJE WETENSCHAP
}

\author{
Over wat in Duitsland aan de vorming van een \\ sociologische discipline voorafging
}

\section{Waardevrijheid en de identiteit van de sociologie}

Wanneer Max Weber in 1904 op zijn reis door de Verenigde staten enige dagen in Chicago verblijft, trekken in deze stad twee zaken zijn bijzondere belangstelling. Hij dwaalt er door de beruchte 'stockyards' en hij brengt een bezoek aan wat men het eerste centrum voor sociaal-cultureel opbouwwerk in de Verenigde Staten zou kunnen noemen: het door Jane Addams geleide Hull House. Vanuit Chicago reist Weber door naar St. Louis waar hij een voordracht houdt op hetzelfde wetenschappelijk wereldcongres waar Lester Ward zijn collega-sociologen toespreekt. Ward noch Small, Giddings of Ross hebben echter met Weber enig contact gezocht. Een gemiste kans, vond menig Amerikaanse socioloog enkele decennia later, toen Webers werk in de Verenigde Staten bekend raakte. Maar hoe zouden Small en zijn collega's Weber ooit hebben kunnen opmerken? In de sectie Sociologie komt Weber niet op de sprekerslijst voor. Hij hield zijn voordracht, in de zevendelige congresbundel afgedrukt onder de titel The Relations of the Rural Community to other Branches of Social Science, in de sectie voor agrarische geschiedenis. Bovendien zoekt ook Weber zelf geen toenadering. In Chicago brengt hij geen bezoek aan Smalls sociale faculteit, en wanneer Weber in New York verblijft, gaat hij niet op visite bij Franklin $H$. Giddings, maar bij de arbeidsinspectrice Florence Kelley, een geestverwante van Jane Addams. ${ }^{1}$

Het is niet moeilijk te voorspellen wat er gebeurd zou zijn wanneer Max Weber onverhoopt toch met de Amerikaanse grondleggers van de sociologie in gesprek was geraakt. Hij zou niet alleen hun quasi-biologische theorievorming veroordelen, maar zeker ook hun wetenschappelijke pretenties op politiek en ethisch gebied. Small en zijn collega's mogen de sociologie dan presenteren als een 'onpartijdige' wetenschap, vanuit Webers gezichtspunt slaan zij in het geheel geen acht op het principe van de waardevrijheid. Van een strikte scheiding tussen 'feiten' en 'waarden' is in hun progressiefevolutionaire vocabulaire geen sprake.

Terwijl de demarcatie van de sociologie in de Verenigde Staten niet verbonden is met pleidooien voor waardevrijheid, treffen we in Duitsland een bijna omgekeerde situatie aan. Alle grondleggers van de sociologie zijn hier nauw betrokken bij discussies over dit thema. In de door economen als Gustav Schmoller en Adolf Wagner gelleide 
Verein fur Sozialpolitik houdt vooral Max Weber felle pleidooien voor het waardevrijheidsprincipe en brengt daarmee een debat op gang dat als de Werturteilsstreit de geschiedenis is ingegaan. En wanneer op initiatief van ondermeer Max Weber en Ferdinand Tonnies in 1909 de Deutsche Gesellschaft fur Soziologie wordt opgericht, profileert deze vereniging zich ten opzichte van andere sociaalwetenschappelijke gemeenschappen door de naleving van het waardevrijheidsprincipe statutair vast te leggen.

Waarom kennen de grondleggers van de sociologie in Duitsland aan de waardevrijheidskwestie zoveel gewicht toe? In de disciplinegeschiedenis van de sociologie staan op die vraag twee bekende antwoorden tegenover elkaar.

\section{Twee legendes}

Tot in de jaren zestig wordt de receptie van het waardevrijheidsdebat beheerst door wat we de legende van de grote breuk zouden kunnen noemen. Volgens deze legende beheersen tot ver in de $19 \mathrm{e}$ eeuw voor-wetenschappelijke speculaties het sociale denken, om pas in deze eeuw plaats te maken voor de meer bescheiden wetenschappelijke aanpak. De aanzetten daartoe vinden we ondermeer in het werk van Weber en Durkheim. In het licht van deze legende marqueert het waardevrijheidsdebat bij uitstek de breuk met het voor-wetenschappelijke denken over staat en samenleving, een breuk die samenvalt met het ontstaan van disciplines als de sociologie en de politicologie. Bekende representanten van deze benadering zijn Talcott Parsons en Arnold Brecht. Volgens Parsons bevrijdde Weber de menswetenschappen uit de greep van 19e-eeuwse ideologieen: "To use the phrase made current in the United States recently by Daniel Bell, Weber heralded "the end of ideology" in the sense in which that concept has been so prominent in the earlier part of the present century. ${ }^{2}$ Brecht spreekt in zijn Political Theory van 'the fundamental turn that scientific political theory took in the early part of this century", die hij als volgt omschrijft: 'Scholars became more generally aware of limitations in the nature of science. The principal tools of science qua science, they found, were observation of facts, measurement, and logical reasoning.3 Men ontdekte kortom de waardevrije wetenschappelijke methode en Weber is in Brechts ogen een van de eerste pleitbezorgers van deze methode in Duitsland.

Wanneer rond 1970 een nieuwe generatie sociologen de discussie over de jdentiteit van de sociologie nieuw leven inblaast door de na-oorlogse sociologie een gebrek aan kritische zin en maatschappelijk engagement te verwijten, krijgt ook de geschiedenis van de sociologie een ander aanzien en makt de legende van de grote breuk plaatst voor de legende van het grote verraad. De vestiging van de academische sociologie dient volgens deze legende niet te worden begrepen als een belangrijk moment in het proces van verwetenschappelijking van het sociale denken, maar als een vorm van maatschappelijke vervreemding: om als academische discipline te worden geaccepteerd verloochent de sociologie aan het begin van de $20 \mathrm{e}$ eeuw haar verwantschap met de socialistische traditie en geeft daarmee haar kritische houding ten opzichte van de gevestigde orde op. Binnen deze visie op de geschiedenis van de sociologie wordt Webers pleidooi voor waardevrijheid geïnterpreteerd als een strategische manoeuvre die Alvin Gouldner in The Coming Crisis of Western Sociology als volgt omschrijft: 'The emerging conception of Academic Sociology as a value-free discipline, along with a tendency to define sociology 
as an analytically distinct specialization, combined to encourage a politics of academic ecumenism. This promised, in effect, that sociology would tolerate the claims of other interests in and out of the university, in return for their toleration of sociology's now truncated ambitions. In short, Academic Sociology entrenched itself in the university by accomodating itself to the political and religious status quo:4

Beide legendes geven aanleiding tot elkaar tegensprekende interpretaties van het waardevrijheidsprincipe. Maar dit neemt niet weg dat deze interpretaties op twee identieke veronderstellingen zijn gestoeld. Om te beginnen wordt in beide gevallen aangenomen dat de grondleggers van de sociologie in Duitsland hetzelfde doel voor ogen stond als hun Amerikaanse tijdgenoten Small, Giddings en Ross, ic. de vestiging van de sociologie als een academische discipline. Het verschil is slechts dat in de Verenigde Staten voor het bereiken van dit doel andere middelen werden aangewend dan in Duitsland. In de tweede plaats beschouwen zowel Parsons als Gouldner het waardevrijheidsprincipe vooral als een pleidooi voor een meer afstandelijke en neutrale houding ten opzichte van levensbeschouwelijke en politieke discussies. 5

De bespreking van wat er aan de vorming van een sociologische discipline voorafging, spits ik in dit hoofdstuk toe op een onderzoek van deze beide veronderstellingen. Daartoe neem ik, om te beginnen, de lokale context in ogenschouw waarin de sociologie in Duitsiand tot ontwikkeling komt. Vervolgens sta ik uitgebreid stil bij de genese en de aard van de Werturteilsstreit.

\section{Duitse aspiraties: sociologie zonder sociologen}

Ook al is de vestiging van de sociologie als een academische discipline in de Verenigde Staten geen vanzelfsprekende ontwikkeling geweest, in vergelijking met de situatie in Duitsland kreeg ze snel haar beslag. Terwijl rond 1900 de sociologie zich in de Verenigde Staten al op meerdere plaatsen de status van een zelfstandige studierichting heeft verworven, worden in Duitsland tot in de jaren twintig geen zelfstandige leerstoelen voor sociologie gecreeerd. ${ }^{6}$ Universiteiten in Duitsland hadden niet alleen geen eigen bevoegdheid ten aanzien van het oprichten van nieuwe studierichtingen, ook hoogleraarsbenoemingen waren een overheidszaak. En vooral in Pruisen, verreweg de machtigste deelstaat van het Keizerrijk, stond die overheid uiterst afwijzend tegenover de sociologie. In Berlijn hield men het vak voor een "onduitse" wetenschap, een toevluchtsoord voor socialisten, radicale liberalen en andere staatsgevaarlijke types. Invloedrijke grondleggers van de sociologie in Duitsland, zoals Max Weber, Ferdinand Tönnies en Georg Simmel, hebben bijgevolg nimmer een leerstoel in het vak kunnen bezetten, want toen die mogelijkheid zich ten tijde van de Weimarrepubliek begon aan te dienen, waren Weber en Simmel dood en stond Tönnies reeds dicht voor zijn emeritaat.

Toch is het niet alleen deze omstandigheid die maakt dat we deze Duitse grondleggers van de sociologie moeilijk op een lijn kunnen zetten met figuren als Small, Giddings en Durkheim. De ontstaansgeschiedenis van de sociologie in Duitsland ontleent haar eigen karakter bovendien aan het feit dat Duitse sociologen zich tot na de eerste wereldoorlog ook niet of nauwelijks voor de vestiging van een eigenstandige sociologische discipline hebben ingezet. 
Max Weber (1864-1920), om met hem te beginnen, heeft zichzelf nooit een socioloog genoemd. Wanneer hij spreekt over 'ons vak' - bij voorbeeld in Wissenschaft als Benf dan bedoelt hij steeds de economie (in Duitsland Nationalokonomie' of Volkswirtschaftslehre geheten). Weber wijst zelfs de oprichting van leerstoelen in de sociologie uitdrukkelijk af Het begrip sociologie verwijst bij hem dan ook niet naar een nieuw type wetenschap: alles wat zich als zodanig presenteert noemt Weber in de rede waarmee hij in 1919 afscheid neemt van de universiteit van Heidelberg ronduit 'Schwindel'? Sociologie is voor Weber steeds een sociaal-wetenschappelijk standpunt gebleven binnen de reeds gevestigde en in Duitsland traditioneel historisch georiënteerde wetenschappen van het recht, de economie, de kunst, de godsdienst, enzovoort.

Meer dan Weber lijkt Georg Simmel (1858-1918) een grondlegger van de sociologie in de geijkte zin van het woord te zijn. Hij presenteert in zijn sociologisch hoofdwerk Soziologie: Untersuchungen uber die Formen der Vergesellschafrigung het vak als een wetenschap die op eigen voeten kan staan. Sociologie, aldus Simmel, bestudeert de sociale relaties tussen mensen en concentreert zich daarbij niet op de toevallige en historisch veranderlijke inhouden van het socialle leven, maar richt zich op de meer stabiele vormen die sociale relaties kunnen aannemen. Toch bedriegt hier de schijn. Simmel koppelt vorm en inhoud niet los van elkaar en hij getroost zich in de praktijk ook weinig moeite de grenzen van zijn onderscheid precies aan te geven. Deze aanpak getuigt niet van een gebrek aan systematisch vermogen - zoals later wel gezegd is - maar hangt samen met de omstandigheid dat Simmels onderscheiding tussen vormen en inhouden van het sociale leven niet geènt is op het positivistische onderscheid tussen universele wetmatigheden en veranderlijke ceteris paribus condities, maar op Kants trancendentale onderscheiding tussen a priori gegeven denkvormen en hun a posteriori te bepalen inhoud. Simmels onderscheiding is dan ook een kennistheoretische abstractie; in de werkelijkheid vormen de beide componenten van het sociale leven een onlosmakelijk verbonden geheel. Binnen dit kantiaanse kader behoudt Simmels sociologie een sterk geesteswetenschappelijke inslag, een element dat met name in de Amerikaanse receptie van zijn werk spoedig naar de achtergrond verdwijnt. Simmels sociologie werd daarin al snel voorgesteld als een a-historische wetenschap van sociale wetmatigheden, als een wetenschap die zich los van de geschiedwetenschap tot een autonome discipline ontwikkelen kon.

Simmel kunnen we ook om een andere reden niet met een figuur als Small gelijk stellen. Simmel is niet alleen van origine filosoof, hij is dat ook altijd gebleven. Net als Weber heeft hij de sociologie nimmer als zijn vakgebied beschouwd. Sociologie had zijn grote belangstelling, maar ze bleef voor Simmel toch een interesse naast vele andere interessen. Steeds bewaart hij ook een zekere afstand tot zijn sociologische geschriften. Zo tekent hij protest aan, wanneer anderen hem op grond van zijn werk tot socioloog bestempelen.

Deze afwijzende houding is in de sociologische disciplinegeschiedenis wel opgevat als een indicatie voor het feit dat Simmel voorzichtig moest opereren uit vrees voor zijn carrière, te meer daar hij naast de beoefenaar van een verdacht vak ook nog eens van Joodse afkomst was. De brief die Simmel in 1899 an de Franse socioloog Bougle schrijft, doet echter vermoeden dat die terughoudendheid een minder dramatische achtergrond heeft. In antwoord op het verzoek een congresbijdrage te leveren, antwoordt 
Simmel:

Den gewünschten Bericht für den Pariser Kongress kann ich leider nicht liefern. Sie dïrfen doch nicht vergessen, dass die Sciences Sociales nicht mein Fach sind. Meine Soziologie ist ein ganz spezialistisches Fach, für das es ausser mir keinen Vertreter in Deutschland giebt, u. den übrigen Sozialwissenschaften, um welche es sich bei dem Kongress handelt, stehe ich nur als Laie gegenüber u. bin deshalb garnicht in der Lage, darüber zu berichten. Es ist mir überhaupt einigermassen schmerzlich, dass ich im Ausland nur als Soziologe gelte während ich doch Philosoph bin, in der Philosophie meine Lebensaufgabe sehe u. die Soziologie eigentlich nur als Nebenfach treibe. Wenn ich erst einmal meine Verpflichtungen gegen diese damit erfüllt haben werde, dass ich eine umfassende Soziologie publiziere - was wohl im Lauf der nächsten Jahre geschehen wird - werde ich wahrscheinlich nie meht auf sie zurückkommen'?

Dit laatste is inderdaad gebeurd. In het eerste decennium van de $20 \mathrm{e}$ eeuw, juist wanneer de sociologie zich in Duitsland een bredere aanhang begint te verwerven, verflauwt Simmels interesse voor het vak. Bij de vorming van de Deutsche Gesellschaft für Soziologie is hij nog zijdelings betrokken, maar van een zetel in het bestuur ziet hij af en de oprichtingsvergadering in 1910 bezoekt hij niet. ${ }^{10}$

Tenslotte Ferdinand Tonnies (1855-1936). Zijn verhouding tot de sociologie is minder ambivalent dan die van Simmel, maar om zijn rol goed in te schatten, moet wel het volgende worden verdisconteerd. Ten tijde van het Keizerrijk bezet Tonnies een marginale positie in zowel de filosofie als de economie. Op het eerste gebied behoort hij in Duitsland tot een van de zeer weinigen die zich op de angelsakische filosofische traditie orienteren. Hij 'habiliteerde' zich in de filosofie met een studie over Thomas Hobbes en ook zijn Gemeinschaft und Gesellschaft: Kommunismus und Sozialismus als empirische Kulturvormen steunt voor een groot deel op zijn verwerking van Hobbes' antropologie en staatstheorie. Doordat hij zich in deze studie bowendien waarderend uitlaat over Marx' historische reconstructie van het kapitalisme, komt Tónnies in Berlijn te boek te staan als een protagonist van het socialisme - dit ondanks het feit dat hij zich distantieert van Marx' waardeleer en revolutionair utopisme. De verschillende studies die Tonnies op het gebied van de 'praktische' economie verricht - bij voorbeeld naar de grote Hamburgse havenstaking in $1896 / 1897$ - zijn om soortgelijke redenen zijn carrière niet ten goede gekomen. 11

$\mathrm{Na}$ de publikatie van Gemeinschaft und Gesellschaft in 1887 groeit Tönnies' sociologische belangstelling, maar hij gaat zichzelf pas werkelijk als een socioloog beschouwen wanneer in het begin van de $20 \mathrm{e}$ eeuw Gemeinschaft und Gesellschaft door jongere academici als $\mathrm{L}$. von Wiese en P. Barth wordt herondekt als een belangrijk sociologisch werk. Als in 1912 een nieuwe druk verschijnt, haakt Tonnies in op deze nieuwe leeswijze door de ondertitel te veranderen in Grundbegriffe der reinen Soziologie. Toch schrijft hij in het nieuwe voorwoord niet zonder spijt: 'Das Werk war für Philosophen bestimmt. Obgleich Männer wie Paulsen und Höffing seine Bedeutung stark hervorhoben, obgleich Wundt es als "gedankenreich" bezeichnete (...); obwohl es in den Geschichten der neuesten Philosophie von Ueberweg-Heinze und von Vorländer (von geringeren zu schweigen) der Erwăhnung, ja Auszeichung für wert erachtet wurde - so blieb doch die 
zeitgenössische Phillosophie im ganzen stumm. Sie hielt die hier vorgelegten Begriffe nicht einmal der Kritik und etwasigen Vernichtung wert. 12 Tot aan de vooravond van de eerste wereldoorlog blijft Tónnies in feite een socioloog in disguise. Hij groeit uit tot een grondlegger van de nieuwe discipline, omdat hij als filosoof niet serieus genomen werd.

\section{De aard en functic van een sociologische vereniging}

Gezien hun aspiraties is het begrijpelijk dat de grondleggers van de sociologie in Duitsland niet het type demarcatiewerk hebben verricht dat Small zo bezighield. Zij zjjn er niet op uit van de sociologie een zelfstandige discipline te maken; zij publiceren geen leerboeken in de sociologie - die beginnen pas na 1918 te verschijnen - en zij richten ook geen sociologisch tijdschrift op. Weber en Tonnies zijn weliswaar drijvende krachten achter de in 1910 opgerichte Deutsche Gesellschaft fur Soziologie, maar deze vereniging is door hen niet met hetzelfde doel opgezet als Small en zijn collega's voor ogen stond toen zij in 1905 de American Sociological Sociery in het leven riepen. Dat het Duitse initiatief niet is ingegeven door het streven een sociologische professie te grondvesten blijkt ondermeer uit het feit dat van een exodus van de Duitse grondleggers van de sociologie uit de oudere Verein fur Sozialpolitik geen sprake is geweest. Max Weber en in zijn voetspoor Werner Sombart en Alfred Weber zetten zich binnen deze vereniging fel af tegen de 'Gelehrtenpolitik' die Schmoller en de zijnen bedrijven, maar niettemin zijn zij na 1910 actief lid gebleven van deze vereniging. ${ }^{13}$

Dat de Duitse sociologenvereniging niet als een afsplitsing van de Verein für Sozialpolitik moet worden beschouwd, illustreert ook het volgende. In 1908, wanneer Simmel nog bij de oprichting van de sociologische vereniging betrokken is, doet hij het voorstel Gustav Schmoller (1838-1917) - het boegbeeld van de Verein en Webers belangrijkste opponent in de waardevrijheidsdiscussie - tot erevoorzitter van de nieuwe vereniging te benoemen. Zover is het niet gekomen (er werd niemand in die functie benoemd), maar de reden daarvoor was niet dat Schmoller een afwijzende houding innam tegenover de sociologiebeoefening, Vanwege de manier waarop hij gestalte gaf aan de Nationalokonomie' staat hij in de disciplinegeschiedenis van de economie zelfs te boek als een socioloog. Schmoller is dan ook een vertegenwoordiger van de zogenaamde jongere historische school in de economie. ${ }^{14}$ In deze traditie, die na de eerste wereldoorlog binnen de economie sterk aan gezag inboet, heeft de economische wetenschap nog de status van een breed opgezette en sterk historisch gerichte sociale wetenschap. Evenals Weber, Simmel en Tönnies gaat Schmoller ervan uit dat economische verschijnselen steeds in samenhang met politieke, sociale en culturele ontwikkelingen moeten worden bestudeerd.

Tenslotte kan er op gewezen worden dat Weber en Tönnies de Duitse sociologische vereniging een functie toeschrijven die sterk op die van de Verein für Sozialpolitik is geènt. $\mathbf{Z i j}$ zien de vereniging vooral als een orgaan dat empirisch onderzoek entameert en dat theoretische discussies organiseert tussen academici met een sociologische belangstelling. Van de 39 leden die zij aanwerven profileren slechts drie zichzelf als socioloog tout court; het overgrote deel van de vereniging bestaat uit historici, juristen, economen, filosofen en theologen. ${ }^{15}$ Dat deze pluriforme samenstelling niet beschouwd wordt als een voorbijgaand fenomeen, komt duidelijk naar voren in Webers rede op de eerste bijeenkomst van de vereniging. Het is niet de bedoeling, zegt hij, dat de vereni- 
ging een besloten Akademie' wordt warvan het bestuur bepaalt wie toetreden mag; ze dient een voor ledere academicus openstaande 'A Arbeitsgemeinschaft' te blijven. Om gegeven de brede samenstelling van de vereniging toch enige lijn en diepgang in de discussies te brengen stelt Weber zelfs voor de vereniging dadelijk op te splitsen in onderafdelingen, om te beginnen op de gebieden van de theoretische economie en de statistiek. 16

Tot aan circa 1920 treffen we in Duitsland well sociologie, maar nauwelijks sociologen aan, zo kunnen we concluderen. Daarmee is de eerste veronderstelling waarop zowel Parsons als Gouldner hun interpretaties van het waardevrijheidsdebat baseren, weerlegd. De nadruk die de grondleggers van de Duitse sociologie leggen op het principe van de waardevrijheid, komt niet voort uit het streven van de sociologie een zelfstandige academische discipline te maken. Toch wil dit niet zeggen dat zij helemaal geen demarcatiewerk verrichten. Die arbeid vindt wel plaats, maar ze kent in Duitsland een andere inzet als in Amerika en ze neemt er ook een andere vorm aan. Meer dan in de Verenigde Staten is de constitutie van de sociologie hier verbonden met een wetenschapspolitiek debat dat vooral tussen leden van de Verein für Sozialpolitik wordt gevoerd. Binnen deze vereniging profileren de latere grondleggers van de Duitse sociologie zich als de pleitbezorgers van een waardevrije sociale wetenschap. Wat houdt dit standpunt in en tegen welke opvattingen is het gericht?

\section{Twee omschrijvingen van het waardevrijheidsprobleem}

Aan de vooravond van de eerste wereldoorlog beleeft de 'Werturtellsstreit' een dramatisch hoogtepunt. Tijdens een speciaal aan de waardevrijheidsproblematiek gewijde vergadering van de Verein fur Sozialpolitik verlaat Max Weber voortijdig de zaal. Volgens de overlevering dekte hij zijn aftocht met de uitroep: 'Het is onmogelijk met idioten te discussięren". Waarom de gemoederen zo hoog opliepen, weten we niet precies. Tegen de gewoonte in werd de discussie niet genotuleerd. ${ }^{17}$

De bijeenkomst was grondig voorbereid. In een rondschrijven vroeg Gustav Schmoller (1838-1917), de toenmalige voorzitter van de Verein fur Sozialpolitik, de deelnemers aan het debat een zogeheten Gutachten te schrijven, waarin zij hun licht lieten schijnen op de volgende vier kwesties: (1) die Stellung des sittlichen Werturtells in der wissenschaftlichen Nationalokonomie, (2) das Verhältnis der Entwicklungstendenzen zu praktischen Wertungen, (3) die Bezeichnung wirtschafts- und sozcialpolitischer Zielpunkte, (4) das Verhältnis der allgemeinen methodologischen Grundsătze zu den besonderen Aufgaben des akademischen Unterrichts'. 18

Volgens Schmoller moesten al deze vier vraagstukken op de vergadering aan de orde komen, maar Weber denkt daar geheel anders over. In zijn Gutachten spreekt hij zich duîdelijk uit over wat volgens hem wel en niet ter discussie staat. Dit opstel, dat vier jaar later (1917) in licht herziene en uitgebreide vorm zal worden gepubliceerd onder de titel Der Sinn der 'Wertfreiheit' der soziologischen und ökonomischen Wissenschaften, begint aldus: Die nachfolgenden Bemerkungen beschränken sich ausdrücklich auf empirische 
Disziplinen (...) Nicht diskutieren möchte ich persönlich auch innerhalb dieses Rahmens beil der Ausschussverhandlung mit Andersgesinnten uber folgende Punkte; en dan noemt Weber achtereenvolgens: het probleem of binnen de Verein politieke kwesties besproken mogen worden; de vraag of men vanaf de katheder waardeoordelen mag uitspreken; problemen rond pseudo-waardevrijheid en de praktische moeilijkheden bij het volgen van het waardevrijheidsgebod; de vraag of alle waardeoordelen even "subjectief zijn. Met name over de kathederkwestie weidt Weber breed uit, maar niet zonder eerst te schrijven: 'Ich bedaure die Hineinziehung dieses Problems'.19

Na de behandeling van punten die niet ter discussie staan, komt Weber bei der Sache selbst. Hierover is hij opmerkelijk kort. Wat voor Weber wel ter discussie staat, is dan ook een 'an sich höchst triviale Forderung', de eis namelijk, "dass der Forscher und Darsteller die Feststellung empirischer Tatsachen (..) und seine praktisch wertende, d.h. diese Tatsache (...) als erfreulich oder unerfreulich beurteilende, Stellungnahme auseinanderhallen solle, weil es sich da nun einmal um heterogene Probleme handelt. Een nader argument vinden we in de tekst niet. Deze eis spreekt voor Weber kennelijk vanzelf. Verderop plaatst hij alleen nog de retorische opmerking In der Streitfrage selbst muss ich abwarten, ob sich wirklich Leute finden, welche behaupten, dass die Fragent ob eine konkrete Tatsache sich so oder anders verhält? warum der betreffende konkrete Sachwerhalt so und nicht anders geworden ist? (...) logisch nicht verschieden seien von den Fragen: was man in einer konkreten Situation praktisch tun solle? unter welchen Gesichtspunkten sie praktisch erfreulich oder unerfreulich erscheinen könne?'. Tussen beide citaten in bespreekt Weber opnieuw een kwestie die (g)ar nicht zur Diskussion gestellt is - wenigstens von meiner Seite', en wel de status en reikwijdte van ethische normen. Weber voelt zich met name op dit punt misverstaan door Schmoller, maar ook deze zogenoemde axiologische kwestie weigert hij te bespreken op de vergadering van de Verein. ${ }^{20}$

Op grond van welke overwegingen komt Weber tot zijn agendavoorstel? Zijn Gutachten biedt enig uitsluitsel. Weber geeft aan waarom hij niet van gedachten wil wisselen over de vraag of men zich vanaf de katheder $z u$ (..) praktischen Wertungen "bekennen" solle oder nicht'. De reden is: "Denn das ist selbst eine gänzlich von praktischen Wertungen abhängige Frage, die eben deshalb unaustragbar ist ${ }^{\prime 21}$ Dit argument stoelt op een nogal streng onderscheid dat Weber maakt tussen theoretische en praktische waardlen. ledereen die wetenschap bedrijf, moet zich wel bekennen tot theoretische waarden als waarheid en consistentie, maar op het gebied van morele of politieke handelingswoorschriften kennen we zulke dwingende keuzes niet. Aan politiek en moraal kunnen verschillende en soms zelf tegenstrijdige warden ten grondslag liggen. $O p$ vragen waarbij praktische waarden een rol spelen zijn derhalve geen eensluidende antwoorden mogelijk. De consequentie van deze opstelling is dat Weber niet wenst te discussiëren over zaken waarover verschil van mening mogelijk is. Hij wil het uitsluitend hebben over kwesties waarbij geen praktische waardekeuzes in het geding zijn en waarvoor een dwingende bewijsvoering geleverd kan worden. De kloof tussen kennen en keuren is zo'n vraagstuk. Hierbij spelen praktische warden geen enkele rol, meent Weber; het gaat uitsluitend orn een algemeen geldend logisch inzicht.

Webers Gutachten kent dus een merkwaardige paradox Over vragen waarover discussie mogelijk is, wil Weber niet discussiëren. Een vraagstuk daarentegen waarover 
volgens hem een debat zinloos is omdat het een even triviaal probleem betreft als $2+$ 2, wil Weber juist wel op de bijeenkomst van de Verein aan de orde stellen. Gegeven deze retorische structuur van Webers bijdrage aan de wardevrijheidsdiscussie is het niet verwonderlijk dat Weber de vergadering tenslotte voortijdig verliet: hij maakte bij voorbaat iedere gedachtenwisseling onmogelijk!

Van kwade trouw hoeven we Weber niet te betichten. In zijn Gutachten weerspiegelt zich duidelijker dan in het latere opstel Der Sinn der 'Wertfreitheit' de invloed die het neo-kantianisme van Wilhelm Windelband en Heinrich Rickert op Weber heeft uitgeoefend. Twee dichotomieèn die in hun versie van het neo-kantianisme centraal staan, nemen ook in Webers denken een prominente plaats in.

Binnen deze filosofische traditie wordt in de eerste plaats een streng logisch onderscheid gemaakt tussen wetenschap en wereldbeschouwing. Alle kantianen, Weber incluis, veronderstellen het bestaan van én methodisch correcte wetenschappelijke bewijsvoering. Deze activiteit wordt opgevat als het denkend ordenen van de empirische werkelijkheid, waarbij waarheid wordt geïdentificeerd met bewijsbaarheid. Alles wat niet dwingend bewijsbaar is, valt bij hen dus buiten het domein van de wetenschap. Tegen deze achtergrond is Webers retoriek te begrijpen. Rationaliteit verbindt Weber met bewijsbaarheid, met logisch dwingende argumentatie, die auch von einem Chinesen als richtig anerkannt werden muss'.22 Wetenschappelijk denken wordt gelijkgesteld aan deductief redeneren vanuit algemeen geldende principes of waarden. ${ }^{23}$

Nog een tweede dichotomie is in dit verband van belang, een tegenstelling die verklaart waarom Weber rationaliteit zo sterk koppelt aan de universele geldigheid van (theoretische) waarden. Het betreft hier de onoverbrugbare kloof die Rickert creeert tussen empirie en waardensfeer, tussen 'werkelijkheid' en 'waarden'. Waarden bestaan niet: 'Bei Werten, die man für sich betrachtet, kann man nicht fragen, ob sie wirklich sind, sondern nur ob sie gelten ${ }^{\prime 24}$ Boven de sfeer van de werkelijkheid verheft zich, volledig heterogeen, de waardensfeer. Tussen beide sferen staat het subject, of zoals Weber zegt de cultuurmens, die in zijn oordelen beide 'werelden' met elkaar verbindt. Van belang voor de vraag of deze oordelen rationeel zijn, is hier niet of men in staat en bereid is zijn oordeel met argumenten te onderbouwen, maar slechts de status van de waarde waarop men zich beroept. Is deze waarde universeel geldig dan is het oordeel rationeel.

Volgens Windelband en Rickert bezitten ook sommigen praktische waarden universele geldigheid. Ondermeer onder invloed van Nietzsche schudt Weber dit deel van de kantiaanse erfenis echter van zich af. ${ }^{25}$ Voor hem bezitten praktische waarden, in tegenstelling tot de waarde van wetenschappelijke waarheid, nimmer universele geldigheid en derhalve ontberen oordelen die uiteindelijk zijn terug te voeren op praktische waarden, rationaliteit. Dit wil niet zeggen, dat over dit type kwesties niet te discussiêren valt. Weber doet bijna niet anders in zijn Gutachten. Maar het punt is steeds: praktische of normatieve debatten zijn in zijn ogen niet rationeel omdat de betreffende waarden geen algemene geldigheid toekomt. Daarom noemt hij oordelen die hier in het geding zijn ook wel 'subjectief, maar dat betekent niet dat het in zijn ogen 'in wezen" zou gaan om gevoels- of smaakuitingen waarover helemaal niet te twisten valt. ${ }^{26}$

Onder invloed van het neo-kantiaanse denken interpreteert Weber dus de moeilijkheden die de verhouding tussen empirische kennis en normatieve uitspraken oproept, als 
een strikt genomen formeel probleem. Webers voorstel alleen dit vraagstuk op de agenda te plaatsen, wordt door zijn opponenten niet geaccepteerd. Als leden van de jongere historische school in de economie staan zij gereserveerd tegenover het neo-kantianisme van Windelband en Rickert. In het yoetspoor van filosofen als Wilhelm Dilthey en Wilhelm Wundt kennen zij aan allerlei waarden wel een objectier bestaan toe. ${ }^{27}$ Waarden vormen niet alleen een logische categorie waarmee wij de werkelijkheid ordenen en beoordelen, mar zijn ook elementen van het menselijk leven die als immanente zedelijke krachten in de menselijke geschiedenis werkzaam zijn, zo betogen zij. Tegen deze achtergrond vatten Schmoller en zijn geestverwanten moeilijkheden in de feit/waarde-relatie niet op als een voor alles logisch-methodologisch probleem, maar als een in de eerste plaats inhoudelijk-axiologisch vraagstuk. Wat wil dat zeggen?

Op Webers bekende uitroep 'Das Hineinmengen eines Sollens in wissenschaftlichen Fragen ist eine Sache des Teufels" ${ }^{28}$ reageert Schmoller als volgt 'Gegenüber $M$. Weber betone ich zunächst, dass ich ihm recht geben würde, wenn ich - wie er - der Ansicht wăre, alle Werturteile seien absolut subjektiv; sie können es sein, aber es gibt neben der subjektiven objektive Werturteile, an denen nicht bloss einzelne Personen und Gelehrte, sondern grosse Gemeinschaften, Völker, Zeitalter, ja die ganze Kulturwelt teilnehmen'. ${ }^{29}$ Schmoller geeft hier aan het waardevrijheidsprobleem een wending die Weber zou verwerpen. Niet de logische kloof tussen waardeoordelen en empirische uitspraken is relevant voor de vraag of waardeoordelen in de wetenschap toelaatbaar zijn. Beslissend is de culturele status van die oordelen.

Op een soortgelijke manier verweent zich ook Heinrich Herkner, een generatiegenoot van Weber, maar behorend tot het kamp van Schmoller, Volgens hem richten Max Weber en zijn geestverwanten hun aandacht uitsluitend op de fundering en niet op de inhoud van (praktische) waardeoordelen. Het subjectieve karakter van die oordelen krijgt daardoor zo'n grote nadruk, dat Weber en zijn medestander Sombart er toe neigen alle waarden over één $\mathrm{kam}$ te scheren. Zij hebben bij voorbeeld geen oog voor het verschil tussen allgemein anerkannte, tiber die aktuellen Parteiprogramme weit hinausreichende höhere politische Zwecke' en niet-algemeen gedeelde 'parteipolitische Werturteile:30 Toch is juist dit onderscheid van belang, omdat volgens Herkner wetenschapsmensen zich slechts dienen te onthouden van waardeoordelen voorzover het daarbij gaat om persoonlijke zedelijke waarden of partijpolitieke doelen. Controversiële waarderingsmaatstaven horen inderdaad in de wetenschappelijke praklijk niet thuis. Zolang daarentegen bepaalde warden en doelen kunnen rekenen op algemene erkenning, ist nicht einzusehen, warum diese der Nationalokonom nicht ohne weiteres als Bewertungsmassstab sollte verwenden dürfen'.31

Schmoller en Herkner willen niet als Weber elk waardeoordeel uit het wetenschapsbedrijf weren. $\mathrm{Zij}$ verdedigen hun standpunt echter op grond van axiologische overwegingen en niet op basis van de logische stelling dat waardeoordelen wel uit feiten zijn af te lleiden. Dit laatste vraagstuk staat in hun kijk op het debat eenvoudigweg niet ter discussie. Deze beide manieren van argumenteren hebben filosofische achtergronden, al moeten we daaruit niet de conclusie trekken dat de controverse geheell en al in een theoretische context staat. Weber en Schmoller kennen niet alleen aan het begrip 'waarde' een verschillende betekenis toe, ze verschillen tevens van mening over de vraag ten opzichte waarvan de menswetenschappen zich primair dienen af te bakenen. Hun 
standpunten verwijzen in dit opzicht naar verschillende demarcatiestrategieen die zich in reactie op historische ontwikkelingen uitkristalliseren. In de volgende twee paragrafen wordt dit wetenschapspolitieke aspect van de Werturteilsstreit nader vitgewerkt.

\section{Schmoller en de vermaatschappelijking van de politiek}

In 1914, wanneer het waardevrijheidsdebat een hoogtepunt bereikt, bestaat de Verein fiur Sozialpolitik ruim veertig jaar. In 1872 houdt de nog jonge Schmoller op de eerste bijeenkomst van deze vereniging de openingsrede. Hierin verwoordt hij treffend de maatschappijvisie van de toen opkomende generatie economen in Duitsland.

In een tijd van toenemende tweespalt tussen ondernemers en arbeiders biedt volgens Schmoller de leer van het economisch liberalisme niet langer soelaas. Wil de strijd tussen bezittende en niet-bezittende klassen niet uitlopen op een omverwerping van de bestaande orde, dan is actief ingrijpen van de overheid in het economisch leven geboden. Dit geluid, zo stelt Schmoller, dringt echter nauwelijks door tot de politieke partijen war de leden van de Verein zich verwant mee voelen. Hoewel deze partijen tot het politieke midden behoren, richten ze zich te zeer op de ondernemersbelangen. Om toch de noodzaak van sociale hervormingen onder de aandacht van de wetgever te brengen, is de Verein fur Sozialpolitik opgericht. Achter de bijdrage die deze organisatie van intellectuelen, journalisten, beambten en (enkele) industrièlen wil leveren aan de oplossing van de 'sociale kwestie', schuilt volgens Schmoller geen bepaald klassebelang of partijpolitieke overtuiging. Daar staat de Verein boven. Wat haar leden bind, is een eensluidende visie op de staat als geheel. Zij is geen in te tomen kwaad, zoals liberale economen betogen, maar das grossartigste sittliche Institut zur Erziehung des Menschengeschlechts. De werkzaamheden van de Verein zijn er dan ook op gericht dit instituut te doen vitgroeien tot eine starke Staatsgewalt, welche, über den egoistischen Klasseninteressen stehend, die Gesetze gebe, mit gerechter Hand die Verwaltung leite, die Schwachen schütze, die unteren Klassen hebe. ${ }^{32}$

Zo'n bejubeling van de staat vindt men niet bij Schmollers Amerikaanse tijdgenoot Sanborn, wat niet weg neemt dat de Verein een zekere gelijkenis vertoont met de in hoofdstuk II besproken American Social Science Association. Ook de Verein is geen disciplinaire of professionele organisatie, ook zij richt zich op een breed scalla van moderniseringsproblemen. Eén thema krijgt in Duitsland echter al snell meer aandacht dan elders.

In 1872 heeft Schmoller de toon gezet voor het politieke en economische denken in de eerste twee decennia van het tweede Duitse Keizerrijk, zo blijkt al snel. Maatschappelijke veranderingen die tussen 1871 en 1890 hun beslag krijgen, maken het mogelijk dat Schmollers ideeen aan invloed winnen. Vlak na de oprichting van de Verein, vanaf 1873 , beleeft de Duitse economie een tot in de jaren negentig aanhoudende periode van laagconjunctuur. $\mathrm{Ze}$ begint met een crisis die, naast de industrie, vooral de landbouw treft. Goedkoop Amerikaans graan dreigt de Europese markt te overspoelen. Eerst voorstanders van vrijhandel, zien de Pruisische hereboeren hun positie nu bedreigd en ageren zij met succes voor een protectionistische politiek. De liberale vrije-markt- 
economie raakt in diskrediet. Ook de industrie verlangt tolmuren om de buitenlandse concurrentie het hoofd te kunnen bieden. Met deze neergang van het economisch liberalisme hangen belangrijke veranderingen samen binnen de sfeer van de politiek. ${ }^{33}$

Voor de vorming van het Keizerrijk beheersten constitutionele controverses de politieke agenda. Kwesties als politieke vrijheid, nationale eenheid en parlementaire vertegenwoordiging boden de conflictstof Sinds het eind van de jaren zeventig domineren daarentegen economische en sociale thema's steeds meer het politieke debat. Ten tijde van de tot 1873 durende hoogconjunctuur mengde de overheid zich nauwelijks in het economische leven en toonden, omgekeerd, de sectoren van industrie, handel en landbouw weinig interesse voor pollitieke vraagstukken. Deze laatste groepen worden nu echter politiek actief. $\mathrm{Zij}$ pogen het economische beleid ten gunste van hun belangen te beinvloeden. Al snel vormen zich machtige lobby-organisaties. Het ontstaan van deze Verbände is én van de belangrijkste matschappelijke ontwikkelingen in de Bismarcktijd. ${ }^{34}$

In dit tijdperk wordt niet alleen de aandacht van meer principieel politieke vragen afgewend, ook veranderen de politieke partijen van karakter. De opkomst van Verbände van industrielen, landadel, middenstand en kleine boeren enerzijds en van vakbonden anderzijds zorgt voor wat men een vermaatschappelijking van de politiek zou kunnen noemen. Geen verheven ideeên maar aardse belangen gaan de discussies meer expliciet beheersen. Veel openlijker dan voorheen worden partijen de parlementaire representanten van maatschappelijke bellangengroepen.

Deze vermaatschappelijking van de politiek biedt het Pruisische beambtendom een rechtvaardiging voor zijn onder Bismarck verstevigde machtspositie. Feitelijk de belangen van de Junkers dienend, wekt het bureaucratische staatsapparaat de illusie als enige instantie te kunnen waken over het Gesamtwohl. Aan politieke partijen is de uitvoerende macht niet toe te vertrouwen, want zij zouden slechts oog hebben voor de eenzijdige belangen van hun achterban.

Toonaangevende intellectuelen zijn dezelfde mening toegedaan. In hun liberaalconservatieve kring oogst de verandering die het politieke leven ondergaat hoofdzakelijk misprijzen. 'Unsere Parteien sind ideenlos, glaubenlos geworden, es sind bloss noch Verbände zur Verteidigung materieller Interessen', merkt éen hunner zuur op ${ }^{35}$ Meer dan ooit wensen historici en economen zich om die reden te distantiëren van partijpolitieke twisten. Politiek is volgens hen ontaard in een egoïstische belangenstrijd tussen matschappelijke klassen. De intellectueel dient echter het oog gericht te houden op het algemene, het nationale belang. Aldus plaatsen wetenschapsbeoefenaren zich op gelijke hoogte met de staatsbeambten: boven de partijpolitiek. ${ }^{36}$

Wellicht door het verlaat tot stand komen van een staatkundige eenheid, kent de verafgoding van de staat in (Pruisisch) Duitsland een lange traditie ${ }^{37}$ De vermaatschappelijking van de politiek zorgt evenwel voor een bondgenootschap tussen intellectuelen en bureaucraten dat niet eerder zo innig is geweest. Beide groepen ontwikkelen in de jaren 1870-1890 een gezamenlijk vocabulaire en eenzelfde stijl van redeneren. Tot de belangrijkste vormgevers van deze stijl behoort Schmoller. De in de jaren zestig dominerende klassiek-liberale economen bestempelen Schmoller en zijn medeoprichters van de Verein nog smalend als Kathedersozialisten. Maar als Bismarck in 1890 terugtreedt, is Schmoller Pruisisch 'geheimraad' en de meest invloedrijke econoom in Duitsland. 
In Schmollers openingsrede voor de Verein fur Sozialpolitik zagen we reeds enkele elementen van de toen in Duitsland opkomende stijl van redeneren verwoord. Schmoller houdt de Verein op afstand van de politieke partijen, maar lieert haar naw aan een staatsapparaat dat boven de maatschappelijke tegenstellingen staat en de zedelijke opvoeding van het volk ter hand neemt. Laten we deze denkbeelden nog iets nader bezien.

\section{De oriëntatie op de staat}

Het in 1871 ingestelde parlement, de Reichstag, steekt in onmacht het huidige Europese parlement naar de kroon. Maar van een uitbreiding van zijn bevoegdheden wil Schmoller niets weten. Het parlementaire ritueel valt hij fel aan. Schmoller ziet de twisten tussen liberalen, conservatieven en socialisten als een puur egoistische belangenstrijd. Der dunkelste Punkt unserer parlementarischen Debatten und Abstimmungen, das ist der Klassenkampf, der Kampf der nackten wirtschaftlichen Sonderinteressen miteinander. Er vergiftet die Parteien, er reisst sie von der Höhe allgemeiner Prinzipien, won dem erhabenen Standpunkt des staatlichen Gesamtinteresses herab zu der leidenschaftlichen Klopffechterei gegenseitiger halbwahrer und unwahrer Vorwürfe, zu schamlosem Schacher, zu Interessenkoalitionen, die in der Tat die Füllung der Taschen der Wähler im Auge haben: 38

Met echte politiek heeft het parlementaire debat in Schmollers ogen weinig van doen. Ware politiek dient volgens Schmoller dan ook niet gebaseerd te zijn op partijdige uiltgangspunten, maar op 'allgemeine Prinzipien'. Hiermee bedoelt hij morele principes. Geen 'subjectieve' klassebelangen, maar 'objectieve' waarden moeten het beleid bepalen. Zo zou bij voorbeeld de aristotelische deugd van de verdelende rechtvaardigheid centraal moeten staan in de sociale en economische politiek. ${ }^{39}$

Een ethisch beleid kan naar de mening van Schmoller uitsluitend door onpartijdige politici worden gevoerd. Voor het weberiaanse onderscheid tussen neutrale bureaucratie en partijdige politici is bij Schmoller geen plaats، Zijn ideale regering bestaat juist uit beambten, uit moreel hoogstaande beambten wel te verstaan. Alleen zij hebben ruim zicht op "das staatliche Gesamtinteresse".40

Constitutionele kwesties, zoals bij voorbeeld het probleem van de politieke vrijheid, worden in dit pleidooi voor een patriarchaal staatsbestel onder de mat geschoven. 'Freiheitsfragen (sind) in erster Linie Bildungsfragen', stelt Schmoller." Hierachter schuilt een staatsopvatting waar hij in zijn rede tot de Verein reeds over spreekt: de staat is een zedelijk instituut. Bij zo'n opmerking denken we al snel aan Hegel. Voor hem is immers de staat de hoogste zedelijke gemeenschap. Pas daarin wordt de zedelijke Idee werkelijkheid, zoals het heet. Hegel verwijst zo de Kerk naar het tweede plan. Over zeden en moraal waken niet langer louter religieuze instanties, maar bovenal de staat. Deze verschuiving is kenmerkend voor de politieke flosofie van het Duitse idealisme. De gedachte dat de staat een opvoedende functie heeft, berust erop.

Schmoller is bepaald geen hegeliaan, maar ook hij meent dat de staat langzamerhand de rol van de Kerk heeft over te nemen. Werd in de middeleeuwen de maatschappelijke en culturele eenheid nog door de religie tot stand gebracht, in de huidige samenleving zijn de divergerende tendensen (strijd tussen klassen en, in Duitsland, tussen religies) dusdanig toegenomen, dat sllechts een krachtige staat de sociaal-culturele eenheid kan 
garanderen, zo argumenteert hij.

Deze visie op staat en (partij)politiek spiegelt zich in Schmollers ideeën over de maatschappelijke rol van de economie. Deze wetenschap is in zijn ogen niet volstrekt autonoom of soeverein, maar is verwant aan een groep wetenschappen die in Duitsland sinds de $18 \mathrm{e}$ eeuw 'Staatswissenschaften' worden genoemd. Deze wetenschappen stonden van oudsher in dienst van het overheidsbeleid en hogere ambtenaren werden er gewoonlijk in opgeleid. Van zo'n nauwe band is Schmoller geen pleitbezorger, daarvoor is hij toch te modern, maar wel houdt hij vast aan het idee dat de economische wetenschap mede tot taak heeft de maatsehappelijke eenheid te versterken door zich te oriënteren op het Gesamtwoht. Als wetenschappelijk onderzoeker moet de econoom voor Schmoller onpartijdig zijn, dat wil zeggen: hij heeft zich niet in te laten met partijpolitiek. Is zo'n 'neutrale' opstelling dan geen politieke keuze? Nee, binnen Schmollers stijl van redeneren niet, omdat daarin het idee van het Gesamtwohl totaal los staat van partijpolitieke idealen. Die laatste idealen verhullen volgens Schmoller immers slechts materièle groepsbelangen, terwijl het algemene belang de belichaming is van ethische waarden als redelijkheid en rechtvaardigheid, waarden die ver boven partijpolitieke twisten verheven zijn. 42 We zien kortom hoe Schmoller het handelen van intellectuelen en staatsbeambten op elkaar afstemt door een nauwe band te leggen tussen 'onpartijdige' politiek en 'onpartijdige' wetenschap. Na 1890 maken historische ontwikkelingen het idee van zo'n band evenwel steeds meer tot een illusie.

\section{Weber en het oplevende constitutionele debat}

In de jaren voor de eeuwwisseling loopt de grote economische depressie ten einde. Ook In Duitsland begint dan een periode van hoogconjunctuur die tot in de eerste wereldoorlog aanhoudt. Het is een tijd waarin de industriele produktie enorm toeneemt, een tijd waarin het kapitaal zich bundelt tot syndicaten, trusts en kartels. Deze ontwikkeling en de daarmee gepaard gaande versnelde urbanisatie beginnen van het Duitse Rijk een moderne kapitalistische natie te maken, zij het in louter economisch opzicht. Want al blijven de agrarische investeringen ver achter bij die van de industrie, de politieke macht van de Pruisische landadel neemt niet af. Ook na Bismarcks val in 1890 houdt de 'Obrigkeitsstaat' zich met gemak staande en blijft, ondanks de opheffing van de socialistenwetten, de sociaal-democratische beweging gemuilkorfd door cen voor haar uiterst ongunstig kiesrechtsysteem. ${ }^{43}$

Desalniettemin laat de opbloei van de conjunctuur het politieke leven niet onberoerd. In de economische belangenstrijd treedt enige ontspanning op, terwijl anderzijds de roep om principieel politieke hervormingen toeneemt. Om geheel verschillende redenen verschuift zowel binnen de sociaal-democratie als in lliberaal-industrięle kringen de aandacht van de Sozialfrage naar de Verfassungsfrage. In de SPD wint het revisionisme aan invloed, onder liberalen ontstaat het besef dat democratisering van het staatsbestel noodzakelijk is om Duitsland te doen uitgroeien tot een imperialistische mogendheid. Met deze verschuiving neemt het politieke debat een ander karakter aan. "Parlamentarisierung und Wahlrechtreform kamen auf die Tagesordnung. Allgemein politische Ge- 
sichtspunkte also traten wieder in den Mittelpunkt, und sie uberformten die wirtschaftlichen Interessengegensătze', merkt een Duitse historicus op. ${ }^{4}$ Vanaf het eind van de vorige eeuw beleeft 20 de discussie over constitutionele kwesties een aarzelende renaissance.

De opkomst van de Werturteilsstreit wordt tot op zekere hoogte door deze historische ontwikkeling in de hand gewerkt. Het meer centraal stellen van de Verfassungsfrage houdt namelijk tevens in, dat de verhouding tussen staat en maatschappelijke en partijpolitieke groeperingen in een ander licht komt te staan. Deze verhouding is alleen in termen van 'algemeen belang' versus 'deelbelangen' te interpreteren als er overeenstemming is over de criteria op grond waarvan men tussen "deel' en 'geheel' kan onderscheiden. Het opleven van het principieel-politieke debat duidt er echter op dat conservatieve intellectuelen en beambten steeds minder in staat waren zo'n consensus af te dwingen.

Het bestaan van een maatschappelijke consensus is voor Schmoller nog een vanzelfsprekende zaak. De doeleinden van het sociaal-economische beleid kunnen volgens hem geen onderwerp zijn van (partij)politieke strijd. Ethische waarden die boven iedere discussie verheven zijn, leggen deze doelen immers vast. De consequentie is dat alle politieke kwesties degraderen tot praktische, technische problemen. Het is deze transformatie die Weber nadrukkelijk afwijst. De schijn dat de richtlijnen voor politiek handelen vaststaan, verdwijnt, zo merkt Weber in het begin van zijn belangrijkste methodologische opstel op, zodra we 'von den konkreten Problemen karitativ-polizeilicher Wohlfahrtsund Wirtschaftspflege aufsteigen zu den Fragen der Wirtschafts- und Sozialpolitik'. Want: 'Das Kennzeichen des sozial politischen Charakters eines Problems ist es ja geradezu, dass es nicht auf Grund bloss technischer Erwagungen aus feststehenden Zwecken heraus zu erledigen ist, dass um die regulativen Wertmassstäbe selbst gestritten werden kann und muss weil das Problem in die Region der allgemeinen Kulrurfragen hineinragt. Und es wird gestritten nicht nur, wie wir heute so gern glauben, zwischen "Klasseninteressen", sondern auch zwischen Weltanschauungen: ${ }^{45}$

Deze passage is rechtstreeks gericht tegen de schmolleriaanse stijl van redeneren, waarin politieke vragen juist tot verzorgings- en opvoedingsvraagstukken worden teruggebracht. Weber vervangt het daarmee samenhangende hierrarchische beeld van de politiek - ver boven de eenzijdige klassebelangen staat het Gesamtwohl - door een strikt pluralistisch beeld. In partijpolitieke debatten gaat het om meer dan het najagen van egoïstische groepsbelangen, het is ook een strijd tussen ideeen, tussen wereldbeschouwingen. Nationale beambtenpolitiek versus naakte klassenstrijd, deze schmolleriaanse dichotomie wordt bij Weber dus doorbroken.

Gezien de hierboven kort aangeduide maatschappelijke ontwikkelingen valt te begrijpen, dat Weber de specifiek politieke discussie een eigen domein verschaft. Maar hij doet meer dan dat. Tegenover de aristotelische visie van Schmoller op de politiek, waarin politiek handelen altijd een vorm van ethisch handelen is, plaatst Weber een meer machiavellistisch beeld. Niet alleen bestaat er volgens Weber een onoverbrugbaar conflict tussen ethiek en politiek, hij gaat zo ver te beweren dat ethische keuzes het innemen van een politiek standpunt in het geheel niet bepalen. ${ }^{46}$ Gerechtigheid willen wij allen, maar daarna scheiden zich de wegen: op politiek niveau is slechts strijd mogelijk. 
Webers scherpe reactie op de schmolleriaanse stijl van redeneren betekent bovendien dat hij de notie van het Gesamtwohl geheel laat vallen. Het idee van zo'n inhoudelijke consensus heeft in Webers politieke theorie geen systematische plaats. In de sfeer van de politiek entbrannte für Weber der Kampf zwischen im Irrationalen verwurzelten, letzten Wertordnungen, unuberbrickbar und prinzipiell unlösbar, wie der Gegensatz zwischen "Got" und Teufel". 47 Dit standpunt impliceert ondermeer een nogal eenzijdig democratiebegrip. Op grond van zijn extreem pluralistisch beeld van de politiek moet Weber democratie wel zien als vooral cen organisatiemodel en niet zozeer als (ook) een maatschappelijk gedragen waardesysteem. ${ }^{48}$

Op de vermenging van ethiek en politiek bij Schmoller reageert Weber kortom met een ontkoppeling van beide sferen. Deze geprononceerde tegenstelling levert de conflictstof voor de Werturteilsstreit. Voor Schmoller staan, zoals gezegd, zowel wetenschapsbeoefenaren als staatsbeambten boven de partijpolitiek. Beide groeperingen houden het oog gericht op het algemene belang, dat door algemeen geldende ethische waarden wordt vastgelegd. Alleen op grond van die waarden kan de sociale wetenschap een oordeel geven over politieke beleidsbeslissingen. Deze waardegebondenheid is voor Schmoller echter synoniem met onpartijdigheid. Voor dit soort onpartijdigheid is in Webers visie geen plaats. Wetenschap is of partijdig of waardevrij, omdat boven de politieke wereldbeschouwingen geen ethisch gefundeerd algemeen belang bestaat. Wanneer echter binnen de politieke sfeer slechts strijd heerst, dan kan de verhouding tussen wetenschap en politiek slechts een middel/doel-relatie zijn. Elke algemeen gedeelde waardemaatstaf ontbreekt dan immers.

\section{Van staatswetenschappen naar sociale wetenschappen}

Op het eind van de $19 \mathrm{e}$ eeuw worden in Duitsland nieuwe ideeen naar voren gebracht over de aard en functie van de menswetenschappen. Uit de vele debatten die in dit tijdperk worden gevoerd, heb ik in dit hoofdstuk een controverse naar voren gehaald die bepalend is geweest voor de wijze waarop "sociologie" zich in Duitsland collectief presenteert, ic. als een samenwerkingsverband van economen, statistici, politieke wetenschappers en historici die zich geheel in dienst stellen van het onderzoek naar maatschappelijke feiten en verhoudingen en die zich binnen dit kader van ledere vorm van politieke; sociaalpolitieke, sociaalethische propaganda voor praktische doeleinden of idealen willen onthouden. Op grond van mijn bespreking van het in de Verein fur Sozial. politik uitgevochten Werturteilsstreit kunnen we de achtergronden en implicaties van deze intentieverklaring nader bepalen. Laat ik daartoe eerst mijn bespreking van de controverse tussen Schmoller en Weber in een drietal punten samenvatten.

Om te beginnen is duidelijk geworden dat het debat niet de scheiding van wetenschap en waarden tot inzet heeft. Zowel Weber als Schmoller erkennen dat men waardeoordelen niet eenvoudigweg uit wetenschappelijke oordelen kan afleiden. Deze overeenstemming neemt echter niet weg dat de meningen over de maatschappelijke rol van de sociale wetenschappen sterk witeenlopen. Bij de bepaling van die rol gaat het in Schmollers ogen om de relatie tussen drie instituties: wetenschap, staat en partijpolitieke 
of maatschappelijke groeperingen. Binnen deze driehoek brengt hij aan de ene kant een nauwe relatie tussen staat en wetenschap aan, terwijl hij aan de andere kant een distantie creèert tussen wetenschap en (partij)politiek en tussen staat en (partij)politiek.

Terwijl Schmoller de statistiek en de economische en politieke wetenschappen nog karakteriseert als "Staatswissenschaften" geeft Weber de voorkeur aan het begrip "sociale wetenschappen'. In zijn plaatsbepaling van deze wetenschappen krijgt de autonomie ten opzichte van de staat veel meer nadruk, juist omdat Weber de staat niet langer beschouwt als een zedelijk instituut dat het Gesamtwohl van de natie representeert. Hij wijst het schmolleriaanse onderscheid tussen 'höhere politische Zwecke' en lagere 'parteipolitische Werturteile' van de hand en stelt in plaats daarvan alle praktische waardeoordelen op cén lijn. Het gevolg hiervan is dat Weber in zijn bijdragen aan het waardevrijheidsdebat niet de triadische relatie tussen staat, wetenschap en (partij)politiek voorop stelt, maar uitgaat van de dichotomie tussen zuiver-wetenschappelijke discussies en praktisch-normatieve discussies.

Deze wending gaat gepaard met een andere conceptualisering van thet waardevrijheidsprobleem, zo kunnen we in de tweede plaats opmerken. Schmoller beschouwt de relatie tussen waardeoordelen en wetenschappelijke oordelen primair als een axiologisch probleem; in zijn benadering is het relevant een duidelijk verschil aan te brengen tussen (met de staat verbonden) ethische waarden en (met partijen en andere maatschappelijke groeperingen verbonden) politieke waarden. Weber daarentegen presenteert het waardevrijheidsprincipe als een methodologisch inzicht; hij benadrukt het formele onderscheid tussen een algemeen geldende wetenschappelijke bewijsvoering en een op praktische waardeoordelen gebaseerde niet-wetenschappelijke argumentatie. Hoewel beiden in een geesteswetenschappelijke traditie staan en de sociale wetenschappen als historische culturwetenschappen opvatten, zet Weber zich zo af tegen de in de Verein dominante 'ethische' stijl van redeneren. Terwijl bij Schmoller en zijn geestverwanten de "Staatswissenschaften' per definitie 'ethische' wetenschappen zijn, snijdt Weber naast de band met de staat ook de relatie tussen wetenschap en ethiek door.

Een derde conclusie betreft de verhouding tussen sociale wetenschap en sociale politiek. Schmollers idee van 'onpartijdigheid' impliceert een expansionistische instelling tegenover sociaalpolitieke vraagstukken, dat wil zeggen: hij meent dat de economische wetenschap deze vraagstukken tot wetenschapstechnische problemen kan omvormen. Schmollers 'onpartijdige' wetenschapsbeoefenaar houdt geen halt voor de poorten van de publieke meningsvorming, maar trekt uit zijn onderzoek conclusies voor het te voeren sociaalpolitieke beleid. De 'verwetenschappelijking' van de publieke en politieke sfeer die met dit expansionisme verbonden is, leidt in Webers ogen tot een ongewenste versmalling van het politieke debat, of zoals hij zegt: Schmoller doet alsof alle politieke vraagstukken in wezen technisch-wetenschappelijke problemen zijn. Tegen dit expansionisme probeert Weber met zijn waardevrijheidsthese een dam op te werpen. Deze these is er dan ook niet alleen op gericht de wetenschappelijke begripsvorming te ontdoen van religieuze, politieke of ethische waardeoordelen, maar keert zich tevens tegen een verwetenschappelijking' van waardegeladen discussies. De these belichaamt, anders gezegd, een restrictionistische visie op de verhouding van wetenschap en sociale politiek. Wetenschapsbeoefenaren dienen zich te onthouden van oordelen over de doelen en waarden waarop ons handelen is georiënteerd, ze kunnen ons slechts informeren over 
de mogelijke middelen waarmee we die doelen menen te kunnen bereiken en over de consequenties die daarmee verbonden zijn. ${ }^{49}$

In het licht van deze conclusies dient het voorop stellen van het waardevrijheidsprincipe in de Deutsche Gesellschaft für Soziologie zich aan als een demarcatiestrategie die er op is gericht de beoefening van sociale wetenschap met methodologische middelen te demarqueren van de met de Duitse staat verbonden 'Gelehrtenpolitik'. Door zich te onderwerpen aan het waardevrijheidsgebod zou het voor wetenschapsmensen mogelijk moeten zijn een 'onderzoeksgemeenschap' te vormen, ook al oriënteren zij zich op verschillende praktische waarden en nemen zij ten opzichte van sociaalpolitieke vraagstukken tegengestelde standpunten in.

Deze methodologische demarcatie van een 'sociologische' benadering van de maatschappelijke werkelijkheid heeft een praktische consequentie. Schmoller en Weber yerschillen niet alleen van mening over de maatschappelijke rol van de menswetenschappen, maar - in het verlengde daarvan - ook over de vraag wie tot de wetenschappelijke discussie over sociaal-politieke vraagstukken kan worden toegelaten. Binnen de Verein fur Sozialpolitik bestaat weinig sympathie voor zowel sociaal-darwinistische als socialistische maatschappijopvattingen en de leiding van deze vereniging weert met name leden van de SPD uit haar gelederen. Deze praktijk spoort met Schmollers idee van 'onpartijdigheid'. Binnen die conceptie geldt het onderschrijven van dominante waardenorientaties immers als een maat voor wetenschappelijkheid. De oprichters van de sociologische vereniging breken met deze koppeling tussen wetenschap en politiek. Het innemen van een middenstandpunt in het politiek debat getuigt niet van een meer wetenschappelijke houding dan het innemen van extreme standpunten, aldus Weber. In het uitnodigingsbeleid voor de nieuwe vereniging wordt deze lijn doorgetrokken. Op politieke en levensbeschouwelijke instelling wordt niet geselecteerd; niet alleen sociaaldarwinistisch georienteerde intellectuelen maar ook socialisten als Eduard Bernstein worden uitgenodigd tot de vereniging toe te treden. ${ }^{50}$

Deze tolerantie ten opzichte van 'andere geesten' wordt mogelijk, zo denkt Weber, omdat 'sociologie' zich binnen de nieuwe vereniging als een zuiver wetenschappelijke activiteit zal manifesteren. De methodologische disciplinering die hij voorstaat zou 'sociologie' niet alleen van een politieke discussilegemeenschap kunnen doen veranderen in een academische 'arbeidsgemeenschap'; ze zou ook een dam kunnen opwerpen tegen de verwetenschappelijking van het leven en de bureaucratisering van de politiek.

In het vorige hoofdstuk is aangegeven hoe Small en zijn collega's socialisten en andere 'amateurs' uit de gemeenschap van sociologen proberen te weren, hoe zij wetenschappelijke objectiviteit verbinden met politieke neutraliteit en ook hoe zij de sociologie presenteren als een ethische wetenschap die maatschappelijke eenheid nastreeft. Deze profilering, zo kunnen we daar nu aan toevoegen, sluit naw aan bij Schmollers plaatsbepaling van de menswetenschappen. De verschillen tussen het geesteswetenschappelijke vocabulaire van Schmoller en het progessief-evolutionair vocabulaire van Small nemen niet weg dat deze talen ons er in beide gevallen toe verleiden waarden in een 'objectieve' hiërarchie te plaatsen, ons wetenschappelijk handelen af te stemmen op een bij voorbaat gegeven algemeen of publiek belang, en politieke thema's te transformeren in sociaalwetenschappelijke problemen. 
Zijn eigen historisch en ethisch georiênteerde economische wetenschap, zo meent Schmoller, stoelt op een bredere wetenschappelijke basis dan de theorieen van liberale en socialistische economen. Bovendien zou ze zich op een politiek 'hoger' standpunt stellen: terwijl zijn wetenschap zich op algemene belangen richt, laten zijn opponenten zich door particuliere belangen leiden. Small, die voor Schmoller grote bewondering had, legt op dezelfde manier een dubbele maatstaf aan voor het beoordelen van wetenschappelijke kennis. Zijn sociologie is niet alleen breder georienteerd dan andere menswetenschappen, ze is ook wetenschappelijker omdat ze neutraal staat ten opzichte van deelbelangen en een hoger, synthetiserend standpunt inneemt.

De deel/geheel-metafoor waarvan Schmoller zowel als Small een rijkelijk gebruik maken, komt in Duitsland eerder onder kritiek te staan dan in de Verenigde Staten. Dit heeft te maken met verschillen in vocabulaires: de kantiaanse traditie waarop Weber zich ondermeer orienteert, heeft in de Verenigde Staten nooit veel aanhangers kunnen vinden. Maar daarnaast speelt wellicht ook een verschil in politiek klimaat een rol. Terwijl in Duitsland de opmars van het socialisme ertoe leidt dat constitutionele vraagstukken weer op de politieke agenda komen te staan, is men in de Verenigde Staten veel minder verdeeld over de inrichting van het staatsbestel. De Constitutie wordt algemeen onderschreven, ook in intellectuele kringen; en het socialisme verwierf er weinig aanhang. In deze situatie is er minder aanleiding een radicaal pluralistisch standpunt in te nemen, zoals Weber doet. Tegen de achtergrond van gedeelde fundamentele waarden blijft men eerder perspectivistisch redeneren, zodat het voor de hand ligt afwijkende meningen als 'eenzijdige' standpunten te interpreteren. Mede hierdoor kon Small zich verwant voelen met Schmollers manier van redeneren, ook al hanteerde hij een meer natuurwetenschappelijke taal dan zijn Duitse collega.

Deze verwantschap tussen Schmollers expansionisme en de manier waarop Small en zijn collega's de sociologie een eigen identiteit proberen te geven, heeft een stempel gedrukt op de latere receptie van Webers waardevrijheidsprincipe in de Verenigde Staten. Overzien we namelijk de Amerikaanse en de Duitse pogingen om 'sociologie' rond de eeuwwisseling een eigen identiteit te geven, dan valt op dat tussen het streven naar waardevrijheid en de pogingen om van de sociologie een zelfstandige academische professie te maken, geen noodzakelijk verband bestaat. Men kan met Weber waardevrijheid bepleiten, zonder van de sociologie een zelfstandig vak te willen maken, en men kan met Small proberen de sociologie een professioneel aanzien te geven, zonder naar waardevrijheid te streven. In de latere verdediging van het waardevrijheidsprincipe zowel als in de latere kritiek daarop wordt met name door Amerikaanse sociologen een dergelijk verband echter juist wel aangebracht. De in de opening van dit hoofdstuk geintroduceerde disciplinaire legendes - de legende van de grote breuk en de legende van het grote verraad - vormen daarvan een goede illustratie. Deze legendes zijn van Amerikaanse oorsprong en delen, zo is opgemerkt, een tweetal veronderstellingen. Niet alleen plaatsen ze het streven naar waardevrijheid in de context van professionalisering en disciplinevorming, tevens verbinden ze de opkomst van het waardevrijheidsprincipe met het uit de weg gaan van politieke en levensbeschouwelijke discussies. Is de eerst genoemde veronderstelling onjuist; de tweede veronderstelling, zo blijkt uit mijn reconstructie van het waardevrijheidsdebat, is niet specifiek genoeg. Niet alleen Weber, maar ook Schmoller neemt immers afstand van de politieke praktijk, maar deze distantie 
neemt in beide gevallen een geheel andere vorm aan en is verbonden met verschillende demarcatiestrategieên. Wanneer Webers stellingname uit haar oorspronkelijke context wordt gelicht en op de expansionistische praktijk van de Amerikaanse sociologie wordt geent, kan inderdaad de neiging ontstaan aan het waardevrijheidspostulaat een 'schmolleriaanse' functie toe te schrijven. ${ }^{51}$ In Duitsland heeft daarentegen niet webers waardevrijheidsprincipe", maar veeleer Schmollers concept van 'onpartijdigheid" de aanzet gegeven tot wat Gouldner a politics of academic ecumenism' noemt. 
Noten behorend bij hoofdstuk IV

1. Zie voor een verslag van Webers omzwervingen in Amerika de biografie die Marianne Weber over haar man schreef: Weber (1926). Voor de bijdragen van Weber en de Amerikaanse sociologen aan het wereldcongres in St. Louis zie Rogers (1905-1907).

2. Parsons (1971): 48. Volgens Parsons brak Weber radicaal met het Duitse geschied. filosofische denken. Vgl. Parsons (1965b). Kenmerkend voor Parsons kijk op de geschiedenis van de sociologie is dat hij 'de grondleggers' van het vak enorm op een voetstuk zet: "The historians of our discipline will have to settle such questions at a future time, but I for one would not hesitate to label all the theoretical endeavours before the generation of Durkheim and Max Weber as protosociology. (...) I feel that the real job of founding was done in the generation from about 1890 to $1920^{\circ}$. (Parsons, gecit. in Lepenies (1981) Bd. 1: xxxi). Zie voor een kritiek op deze gedachtengang Giddens (1977), Turner (1986).

3. Brecht (1959): 4.

4. Gouldner (1970): 137. Al wordt dit standpunt pas in de jaren zeventig populair, het is al eerder verdedigd door Georg Lukács; zie Lukács (1954): 524 e.v..

5. In 'Anti-Minotaur: the myth of a value-free sociology' interpreteert Gouldner het waardevrijheidsgebod eveneens vooral als een pacificatiestrategie: "Weber's proposal of the value-free doctrine was, in part, an effort to establish a modus vivendi among academicians whose political commitments were often intensely felt and in violent oppostion.' Andere functies van de doctrine die Gouldner onderscheidt beklemtonen steeds ditzelfde punt: '(...) one of the latent functions of the value-free doctrine is to bring peace to the academic house, (...)'; en elders: 'His promotion of the value-free doctrine may, then, be seen (...) as an effort (...) to depoliticize the University'. Gould. ner (1962): 199 e.v..

6. Zie Harding (1977); Käsler (1984).

7. Zie Lepenies (1985).

8. Vgl. Helle (1988), Rammstedt (1988b). Voor de Amerikaanse receptie van Simmels werk zie Levine (1976).

9. Gecit. in Lepenies (1985): 293-294.

10. Vgl. Papcke (1985).

11. Zie voor Tönnies" intellectuele biografie Jacoby (1971), Bickel (1991).

12. Tönnies (1912): iv.

13. Dat Weber c.s. zich niet tegen de Verein wilden afzetten, wordt benadrukt door Rammstedt (1988a).

14. Over deze school zie Schumpeter (1954): $800-824$.

15. Zie Käsler (1981).

16. Weber (1924): 432-433.

17. Bruun (1972): 20; Boese (1939): 147 .

18. Gecit. in Boese (1939): 145 .

19. Weber (1914): 102.

20. Weber (1914): 113-118. Met 'waardevrijheid' bedoelt Weber steeds vrij van (praktische) waardeoordelen'. Datgene wat wij nu sociale wetenschappen noemen, zijn in Webers ogen cultuurwetenschappen; deze wetenschappen ordenen de werkelijkheid altijd vanuit (historisch veranderlijke) waarden, een operatie die Weber samenvat onder het begrip 'Wertbeziehung'. Het waardevrijheidsgebod is door logisch-positivisten en kritisch rationalisten wel uitgelegd als een pleidooi voor 'zuivere' sociale wetenschap. Weber kende het Anglo-Amerikaanse onderscheid van zuivere en toegepaste weteenschap echter niet: cultuurwetenschap kan zich in zijn ogen nooit losmaken van de historische context waarin ze beoefend wordt. Vgl. Beck (1974), Tenbruck (1986), De Wilde (1989). 
21. Weber (1914): 103/104.

22. Weber (1904): 155 .

23. Vgl. Polak (1948): 71; Turner/Factor (1984): 36; Wegener (1962): 90.

24. Rickert (1921): 21.

25. Voor Webers relatie tot Nietzsche zie Oakes (1982); Sica (1988).

26. Webers positie moet dus niet verward worden met het zogenoemde emotivisme dat in dezelfde tijd met name in Engeland veld wint. Een dimensie van het waardevrijheidsdebat die hier onbesproken blijft, is de relatie met ontwikkelingen in de theoretische economie. Oostenrijkse economen als Menger, Böhm-Bawerk en filosofen als Meinong en Ehrenfels maken van het begrip 'waarde' een relationeel begrip: goederen hebben geen waarde' opzichzelf, maar alleen in relatie tot de persoon die er waarde aan hecht. Deze betekenisverschuiving houdt ondermeer in dat het onderscheid tussen wat mensen begeren en wat (in objectieve zin) begerenswaardig is, uit de economie verdwijnt. Het begrip 'waarde' wordt gesubjectiveerd en de studie ervan verhuist van de filosofie naar de psychologie: een ding of een goed krijgt waarde' omdat mensen ze begeren. Weber staat niet onwelwillend tegenover Menger c.s., maar van hun psychologisme moet hij weinig hebben. Waardeoordelen zijn altijd oordelen, meent de kantiaan Weber; anders dan gevoelens of begeertes staan ze open voor discussie en kritiek. Vgl. Satris (1982), Schluchter (1978),

27. Vgl. Schmollers lofrede op Dilthey in Schmoller (1883). Voor de relatie met Wundt zie Surányi-Unger (1927).

28. Weber (1924): 417.

29. Schmoller (1893): 78.

30. Herkner (1912): 531 .

31. Ibid.: 531. Het is te eenvoudig de waardevrijheidsstrijd helemaal terug te voeren op een generatieconflict, zoals b.v. Scaff (1986) doet. Niet alleen wordt Schmoller bok door jongeren gesteund, Weber krijgt steun van Schmollers generatiegenoot L. Brentano (zie Brentano (1911)). De interpretatie van de waardevrijheildscontroverse als een generatieconflict gaat terug op Meinecke (1922).

32. Schmoller, gecit. in Boese (1939): 8.

33. Vgl: Rosenberg (1967): 39. Zie voor het volgende ook Blackbourn Eley (1984).

34. Vgl. Nipperdey (1973).

35. Gecit. in Rosenberg (1967): 129.

36. Vgl. Bruch (1980) en Lindenllaub (1967).

37. Zie Plessner (1959).

38. Gecit. in Lindenllaub (1967): 581.

39. Vgl. Schmoller (1893).

40. Vgl. Verhandlungen der Generalversammlung in Mannheim (1905), Schriften des Vereins fur Sozialpolitik, 116 Bd., Leipzig 1906.

41. Schmoller (1898): 63.

42. Vgl. Schmoller (1897b); Schmoller (1912). Ten aanzien van wetenschappelijke ontwikkeling in de staatswetenschappen (inclusief de economie) legt Schmoller dan ook een dubbele maatstaf aan. Op de stelling dat alle theorieen evenveel recht van spreken hebben, antwoordt hij: "Wir werden vielmehr behaupten, dass wir notwendig die zu gleicher Zeit neben einander stehenden und sich bekämpfenden Theorien und Standpunkte für höher oder niedriger stehend erklären müssten 1. je nachdem sie sich auf das gesammte gesicherte Wissen der Gegenwart in seiner vollendetsten Form stützen oder auf ein partielles, und 2. je nachdem der Urteilende seinen Standpunkt höher oder niedriger gewählt, dabei von den partikularen zu den allgemeïnen höchsten Interessen sich erhebt oder nicht.' Schmoller (1897a): 262.

43. Vgl. Wehler (1980), Hentschel (1983).

44. Nipperdey (1973).

45. Weber (1904): 153.

46. Weber (1914): 117/118. 
47. Mommsen (1974): 47.

48. Zie Tijmes (1977): 148. Vgl. ook Turner/Factor (1984), Mommsen (1959).

49. Het onderscheid tussen een expansionistische en een restrictionistische visie op de relatie tussen wetenschap en politiek ontleen ik aan Graham (1981).

50. Zie Papcke (1985).

51. In de Verenigde Staten ging men met name in de jaren vijftig 'waardevrijheid" interpreteren als politieke neutraliteit en onpartijdigheid. Wanneer de socioloog Becker hiertegen ageert, dan is het dan ook niet toevallig dat zijn betoog uitmondt in een pleidooi voor partijdigheid. Tegenover 'onpartijdigheid' leek dit het enige alternatief te zijn. Zie Becker (1967). Vgl. Beck (1974). 


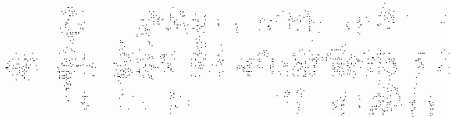

a

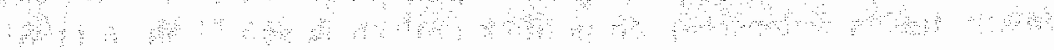

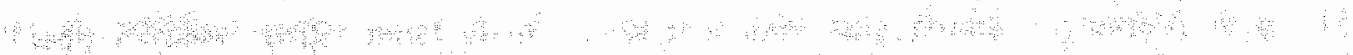

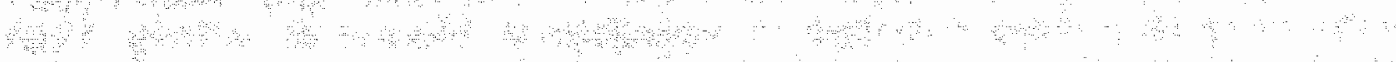

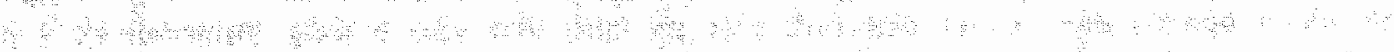

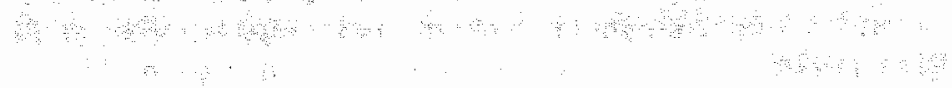




\section{SOCIOLOGIE ALS PEDAGOGIE}

\section{Over de vorming en identiteit van een sociologische discipline in Duitsland}

\section{Het lot van het waardevrijheidsgebod}

"Ik heb de eer om namens het presidium de eerste Duitse sociologendagen hiermee te openen. Wanneer het geoorloofd zou zijn in een naar huidige maatstaven zeer gematigde reclamestijl te spreken, dan had ik mijn rede kunnen beginnen met de woorden: "De sociologie heeft de toekomst ${ }^{r}$. Ik beperk me er echter toe de verwachting en de hoop uit te spreken, dat de sociologie een toekomst heeft.' Met deze kleine scherts opent Ferdinand Tönnies op 20 oktober 1910 de eerste bijeenkomst van de Deutsche Gesellschaft fur Soziologie. Na Tönnies' toespraak is het echter met de ironie gedaan. Tijdens de drie dagen durende conferentie zien Weber en Tönnies zich tot dertien keer toe gedwongen de discussie te onderbreken om deelnemers te herinneren aan het statutair vastgelegde waardevrijheidsgebod.

Soms was de aanleiding klein en in onze ogen zelfs futiel. Zo gold een misprijzende opmerking over de slavernij in het antieke Griekenland al als een ongeoorloofd waardeoordeel. Maar vaker nog was er alle reden een spreker af te hameren, zoals in het geval van Alfred Ploetz, die tijdens zijn voordracht over de begrippen ras en maatschappij erin slaagde het waardevrijheidsgebod geen enkele maal te gehoorzamen. Ploetz' opmerkingen over de mindere raskenmerken van negers, kwam hem op een ernstige reprimande van Max Weber te staan. 1

Instemmen met het waardevrijheidsgebod betekent nog niet dat men het in de praktijk ook opvolgt, zo bleek op de eerste bijeenkomst van de Duitse sociologenvereniging. Weber had met die mogelijkheid onvoldoende rekening gehouden, zoals hij ook niet had voorzien dat de fixatie op het gebod een nadelig effect op het onderlinge debat zou hebben. Het principe bleek te werken bij het onderkennen van 'kleine' overtredingen, maar in die situaties wekte het tot de orde roepen van sprekers eigenlijk alleen maar irritatie op. Voor het onderkennen van 'grote' overtredingen, waar het principe toch vooral voor was bedoeld, schoot het statuutsartikel daarentegen juist tekort. Want wie zich er strikt aan wilde houden, was geneigd tevens afstand te doen van een aantal wapenen waarmee men zich bij voorbeeld tegen een racistisch getoonzette verhandeling kon verweren. Zo leek het opperen van fundamentele bezwaren in dat geval bijna onmogelijk. Breng tegen iemand als Ploetz in dat alle rassen in principe gelijkwaardig zijn, of dat het begrip 'ras' niet thuishoort in een sociaal-wetenschappelijk 
betoog. Zou hij dan niet kunnen repliceren dat deze kritiek allesbehalve waardevrij' is? Webers angstvallige poging zelf niet de fouten te maken die zijn opponent beging, bracht in elk geval met zich mee dat de discussie uitliep op een twist over de vraag of negers al dan niet stinken. Zo richtte de aandacht zich op een empirisch detail, dat hoe belangrijk ook, toch de kern van het meningsverschil niet raakte.

Lag dit onvoorziene effect van het waardevrijheidsgebod misschien reeds besloten in de wijze waarop de sociologievereniging gestalte kreeg? Net zoals de Verein für Sozialpolitik diende de nieuwe vereniging primair een discussieplatform te vormen, maar terwijl de leden van de Verein onderling verbonden waren door hun afwijzing van zowel het laissez faire liberalisme als het socialisme, ontbeerden de leden van de sociologenvereniging een stel gezamenlijke vijanden. Theoretische of politieke herkomst vormde immers geen criterium voor het lidmaatschap. En ook de gedachte aan een gezamenlijke, professionele toekomst bond de leden vooralsnog niet aaneen. Tengevolge hiervan trad in Frankfurt een bont gezelschap aan, dat de verdedigers van een waardevrije' wetenschapssbeoefening met een nieww probleem confronteerde, een probleem dat zich bij de in de Verein gevoerde Werturtellsstreit niet of nawwelijks had aangediend.

Schmoller en Weber verschilden van mening over de relaties tussen staat, politiek en wetenschap, en ook over de status van waarden en de rol van waardeoordelen in de wetenschap. Maar ze streden niet primair over de vraag hoe men eigenlijk een waardeoordeel als een waardeoordeel herkent. Binnen de geesteswetenschappelijke traditie waar zij zich beiden op oriënteerden, bestond dan ook een zekere overeenstemming over de vraag wanneer er sprake is van waarderen en wanneer niet. Webers waardevrijheidspostulaat, zo kunnen we daaraan toevoegen, veronderstelt ook dat we een eenduidig onderscheid kunnen aanbrengen tussen feiten en waarden. Hij gaf zich onvoldoende rekenschap van de omstandigheid dat consensus over wat als feit of als waardeoordeel $t e l t$, geen vanzelfsprekende zaak is, maar slechts in een speciffek geval veronderstelt kan worden. Alleen tegen de achtergrond van een gedeeld of een elkaar overlappend vocabulaire leidt het onderscheiden van feiten en waardeoordelen niet tot diepgaande meningsverschillen.

Veel minder dan de Verein bestaat de nieuwe sociologenvereniging uit een select gezelschap, een verschil dat meteen een grotere variatie in vocabulaire met zich meebrengt. Naast academici die 'sociologie' in de geesteswetenschappelijke traditie plaatsen, treden nu ook pleitbezorgers van een natuurwetenschappelijke "sociologie' naar voren; naast conservatieve eugenetici treden ook radicale marxisten tot de vereniging toe. ${ }^{2}$ Weliswaar zijn zij bijna allen van mening dat wetenschap en politiek twee verschillende zaken zijn en dat waardeoordelen in de wetenschap niet thuishoren. Dat neemt echter niet weg dat er tussen de verschillende stromingen en geledingen grote onenigheid bleek te bestaan over kwesties als hoe dit onderscheid daadwerkelijk moet worden aangebracht en waar de grens tussen empirische uitspraken en waarderingen nu precies ligt. Daarmee faalt niet alleen de poging om 'sociologie' als collectieve onderneming slechts op grond van een methodologisch demarcatiecriterium een eigen identiteit te verschaffen. Binnen de nieuwe vereniging krijgt het waardevrijheidsprobleem bovendien een nieuwe dimensie, zoals Weber aan den lijve ondervindt. In zijn ogen overtreedt iemand als Ploetz overduidelijk het waardevrijheidsgebod, maar omdat de laatste zich naar eigen overtuiging strikt aan de feiten houdt, is Weber in de discussie min of meer 
gedwongen datzelfde te doen. Het nieuwe probleem dat Weber hier parten speelt, is de klaarblijkelijke relativiteit van het feit/waarde-onderscheid: wat binnen het ene vocabulaire als een waardeoordeel telt, kan binnen een ander vocabulaire als een feit figureren.

Nadat de Duitse sociologievereniging in 1912 voor de tweede maal bijeen komt, wordt het Weber duidelijk dat hij binnen dit nieuwe gezelschap slechts een Pyrrusoverwinning heeft behaald. Slechts eén spreker, zo oordeelt hij, houdt zich daadwerkelijk aan het waardevrijheidsgebod, of althans aan zijn uitleg daarvan. Daarmee is voor Weber de maat vol en hij zegt zijn lidmaatschap op: [I]ch habe es absolut satt, stets erneut als Don Quixote eines angeblich undurchführbaren Prinzips aufzutreten und peinliche "Szenen" herbeizuführen" ${ }^{3}$ Met Webers vertrek uit de Deutsche Gesellschaft fur Soziologie verliest het idee van een institutioneel vastgelegd waardevrijheidsgebod haar belangrijkste pleitbezorger. Wanneer de vereniging na de eerste wereldoorlog weer bij elkaar komt, wordt het gebod zonder veel discussie uit de verenigingsstatuten geschrapt.

\section{Het succes van 'slechte' sociologie}

Leopold von Wiese, die de Duitse sociologendagen vanaf het begin heeft bijgewoond, schrijft in zijn memoires blij te zijn dat hij en zijn collega's das Joch der Werturteilspolizei snel van zich hebben afgeschud. ${ }^{5}$ Na de tweede wereldoorlog vormt zich onder sociologen evenwel een ander oordeel. Vooral in de jaren zestig wordt door dan spraakmakende sociologen als Dahrendorf, Jonas en König een uiterst negatief beeld van de sociologiebeoefening in de republiek van Weimar gecreeerd. Het schrappen van het waardevrijheidsartikel uit de statuten van de sociologievereniging (door hen veelal geinterpreteerd als het terzijde schuiven van het waardevrijheidsidee uberhaupt) is in hun ogen eén van de ontwikkelingen die illustreert hoezeer de sociologiebeoefening in Duitsland na de dood van Simmel en Weber terugvalt in filosofische speculatie en abstracte systematiek, waarbij elk contact met de werkelijkheid verloren gaat. Met name König windt er geen doekjes om: "Dit was de tijd waarin de Duitse sociologie haar eigenlijke taak volkomen uit het oog verloren had en zich doodliep op het alternatief Hegel of Marx, in plaats van in te zien dat een werkelijk sociologische theorie slechts met uitsluiting van allebei kon worden opgebouwd. Onafhankelijk van dit moordende alternatief kabbelde alleen de zogenaamde "formele" sociologie nog voort met haar nietszeggende algemeenheden, die zich weliswaar verre hielden van (...) de polemieken van de rechts- en linkssociologen, maar in plaats daarvan de sociologie beroofden van haar levenskracht:"6

Zulke felle veroordelingen zijn ondermeer ingegeven door politieke motieven. Vooraanstaande sociologen hadden een besmet verleden en ook zij die geen Nazipropaganda hadden bedreven, waren in veel gevallen tot 1933 (of nog tot in de jaren daarna) blind geweest voor het nationaal-socialistische gevaar. ${ }^{7}$ In plaats van te waarschuwen tegen antidemocratische tendensen deden sociologen volop mee aan het kweken van een crisis- en ondergangsstemming die aan de ineenstorting van de republiek bijdroeg. Toch heeft niet alleen het Nazi-trauma een schaduw over de Weimarsociologie geworpen. Na de tweede wereldoorlog leeft onder jongere sociologen de intentie geheel te breken met de Duitse sociologische traditie. Men wendt de blik naar Amerika en 
Frankrijk. Ook in de Bondsrepubliek zow de sociologie als empirische discipline nu dan eindelijk van de grond moeten komen. ${ }^{3}$ Bij zulke pogingen een nieuwe orientatie in gang te zetten en gezag te verlenen speelt disciplinegeschiedenis een legitimerende rol. Om ruimte te scheppen voor wat Kónig de opbouw van werkelijk sociologische theorieën noemt, was het noodzakelijk de Weimar-episode uit de geschiedenis van de sociologie weg te schrijven.

Sinds de jaren zestig heeft het beeld van de Weimarsociologie meer nuance gekregen. Mede door de herontdekking van zijn vroege geschriften staat de kennissociologie van Karl Mannheim weer volop in de belangstelling. Tevens heeft er een herwaardering plaatsgevonden van het werk van sociaal-democratisch georienteerde sociologen als Theodor Geiger en Hans Speier, als ook van de sociologische studies die door leden van de "Franfurter Schule' zijn verricht. Al deze auteurs maakten echter geen deel uit van de hoofdstroom van de Weimarsociologie, met uitzondering van Mannheim namen zij binnen de Deutsche Gesellschafi fur Soziologie een marginale positie in of ontplooiden hun activiteiten geheel en al buiten de sociologische gemeenschap om. Zo bestond er tussen de lleden van de 'Frankfurter Schule' en sociologen als Mannheim en L. von Wiese geen enkel intellectueel contact. ${ }^{\text {? }}$

Door de toegenomen aandacht voor toenmalige 'randfiguren' heeft het negatieve oordeel over de sociologiebeoefening in de republiek van Weimar een minder categorisch karakter gekregen. Sociologen van tegenwoordig nemen niet langer afstand van alles wat hun Duitse vakgenoten in de jaren twintig en dertig naar voren hebben gebracht. Ten aanzien van auteurs die ten tijde van de republiek van Weimar als vooraanstaande sociologen bekend stonden, heeft het oordeel zich echter nauwelijks gewijzigd en is ook het uitgangspunt voor historisch onderzoek lange tijd dezelfde gebleven. Waarom, zo vroeg König zich af, hebben sociologen als $L$. von Wiese, P. Barth, H. Freyer, A Vierkandt, A. Weber en ook $M$ Scheler (voorzover het zijn sociollogisch werk betrof) zich niet aan hun eigenlijke taak gewijd? Waarom, zo luidt de vraagstelling van de Amerikaanse historica Schad in een bekende studie over de Weimarsociologie, vestigden deze sociologen niet een traditie van empirisch onderzoek die vergelijkbaar is met de wijze waarop de Amerikaanse sociologie zich in de jaren twintig en dertig heeft ontwikkeld? 10 $^{10}$

Weber en Simmel hadden niet de intentie van de sociologie een academische discipline te maken. Veel van hun navolgers stellen zich daarentegen wel dat doel. En meer nog: zij zijn er ook in geslaagd de sociologie als zelfstandig vakgebied te vestigen. Hoe is dat evenwel mogelijk geweest, wanneer zij (of tenminste haar hoofdstroom) haar eigenlijke taak volkomen uit het oog verloren had', zoals König zegt? Hoe kon 'slechte' sociologie toch succesvol zijn? Aan de hand van twee exemplarische voorbeelden zal in dit hoofdstuk worden geprobeerd deze paradox op te lossen.11

\section{Twee Weimarsociologen}

Het eerste sociaal-wetenschappelijke onderzoeksinstituut in Duitsland staat in Keulen. Het wordt in 1919 opgericht op initiatief van de pas benoemde 'Oberbürgermeister", Konrad Adenhauer, die wetenschappelijk onderzoek naar mede door de eerste wereldoorlog opgeworpen sociale problemen van groot belang acht. Het door de stad Keulen gefinancierde instituut kent een sociaal-politieke en een sociologische afdeling en deze 
laatste afdeling krijgt twee directeuren. Een van hen is Leopold von Wiese (1876-1964), die deze functie tot 1934, als het instituut door de nationaal-socialisten wordt gesloten, combineert met een hoogleraarschap aan de Keulse universiteit. De ander is Max Scheler (1874-1928). ${ }^{12}$

L. von Wiese ontplooit in Keulen een grote activiteit, maar in een geheel andere richting dan men op grond van zijn functie zou verwachten. Onderzoeksopdrachten van het stadsbestuur neemt hij niet aan en ook wetenschappelijk werk dat op enigerlei wijze voor de stad van nut zou kunnen zijn, heeft hij niet verricht. Wieses intellectuele aandacht gaat uit naar de opbouw van een afgerond sociologisch systeem, door hem 'Beziehungslehre' genoemd. Deze 'Beziehungslehre' ontlokt in de jaren twintig en dertig veel kritiek, maar wordt toch zowel binnen alsook buiten de sociologische gemeenschap serieus genomen. L. von Wiese ontwikkelt zich in de republiek van Weimar dan ook tot een vooraanstaand socioloog. Zelfs direct na de tweede wereldoorlog wijst níets er nog op dat het met zijn roem snel gedaan zou zijn. Na Wieses dood raakt zijn werk echter onmiddellijk in de vergetelheid. De 'Beziehungslehre' verhuist naar het rariteitenkabinet van de sociologiegeschiedenis, waarin ze sindsdien figureert als een mislukte poging de 'formele' sociologie van Simmel systematisch uit te werken.

Naar de mening van Simmel moet sociologisch onderzoek zich primair richten op de stabiele vormen en niet op de steeds veranderende inhoud van sociale processen. Zijn sprankelend essayistisch werk verwerd evenwel in de handen van zijn navolger $L$. von Wiese tot een dor boekhoudkundig overzicht van allerlei vormen van sociale relaties, zo heet het sinds de jaren zestig. ${ }^{13}$ Dit gangbare beeld van Wieses leer sluit naww aan bij het al gememoreerde algemene beeld van de Weimarsociologie: na een periode van briljante grondleggers treedt het verval in. Maar het oordeel dat $L$. von Wiese zich vrijwel uitsluitend (heeft) beziggehouden met het systematiseren en ordenen van de door Simmel reeds besproken sociologische vormen ${ }^{14}$ getuigt tevens vān het feit dat men niet meer naar zijn werk omkijkt.

Evenals Simmel vat $L$. von Wiese de sociologie niet op als een synthese van alle sociale wetenschappen, maar als een wetenschap met een eigen object. Dit object is noch het afzonderlijke individu noch de samenleving als geheel, maar de wisselwerking tussen individuen. ${ }^{15}$ Tot zo ver is de 'Beziehungslehre' van $\mathbb{L}$. von Wiese verwant aan Simmels 'Soziologie'; bij de nadere bepaling van dit object van sociologisch onderzoek scheiden zich evenwel de wegen. Simmels object is een filosofisch construct; de vorm en inhoud van sociale processen zijn in werkelijkheid niet los van elkaar te begrijpen. Simmel gaat het bovendien om bepaalde vormen van vermaatschappelijking, zoals bovenen onderschikking, concurrentie, nabootsing, arbeidsdeling, enzovoort. Kenmerkend voor Simmels sociologie is dat deze vormen niet terug te voeren zijn op eén basisvorm, net zoals dat bij geometrische vormen ook niet mogelijk is. Nog in een ander opzicht is 'geometrie van de samenleving' een goede metafoor voor Simmels onderneming. De vormen van vermaatschappelijking zijn bij Simmel, evenals geometrische vormen, niet direct observeerbaar. Om vorm van inhoud te onderscheiden heeft elke socioloog steeds opnieuw een grote dosis intuitie en abstractievermogen nodig. ${ }^{16}$

Het uitgangspunt van de "Beziehungslehre' ligt elders. L. von Wiese is het niet te doen om de alleen via abstractie te traceren vormen van vermaatschappelijking; hij wil de reële betrekkingen tussen individuen voor eens en voor altijd in kaart brengen. 
Onderzoek naar de intenties van individuen die in een betrekking tot elkaar staan, is volgens $\mathrm{L}$, von Wiese een zaak van de psycholoog. Wat overblijft voor de socioloog is onderzoek naar de wisselende distantiering tussen individuen en tussen groepen. Welche Distanzierung oder Distanzierungsverschiebungen liegen vor? Das ist die Kernfrage.17 Aldus is het voor $\mathrm{L}$. von Wiese mogelijk met behulp van twee polaire categorieën het gehele sociale leven te ordenen. Individuen treden op elkaar toe en stoten elkaar af ( $\mathrm{Zu}$ einander vs. Auseinander), groepen smelten samen of splitsen zich op (Amalgamierungen vs. Scheidungen). Het van hieruit opgebouwde systeem is geen geometrie, maar eerder een mechanica van de samenleving. Wieses 'Beziehungen' zijn dadelijk observeerbare krachten en processen, geen abstracte ordeningsprincipes zoals Simmels vormen dat zijn. Het kantiaanse denken, dat bij Simmel een grote rol speelt, heeft op L. von Wiese dan ook nauwelijks invloed gehad Hij bouwt niet zozeer voort op Simmel als wel op Spencer. Wieses centrale begrippen zijn namelijk weinig anders dan Duitse equivalenten voor de door Spencer gemunte concepten integratie en differentiatie. ${ }^{\mathbf{1 8}}$

L. von Wiese begon zijn academische carrière met een proefschrift over Spencer en we kunnen hem in plaats van Simmels navolger beter de Duitse Spencer noemen, waarbij het bijvoeglijk naamwoord precies het verschil aangeeft. Als Duits intellectueel verwerpt $L$. von Wiese Spencers biologisme en sociaal-darwinisme. Daardoor ontneemt hij echter de dynamiek aan het spenceriaanse systeem. De historisch georiënteerde fysiologie van het maatschappelijke leven, zoals we die bij Spencer vinden, keert bij $L$. von Wiese terug als een ahistorische morfologie.

Toch levert dit stukje ideeëngeschiedenis ons nog niet alle middelen om Wieses onderneming te begrijpen. $L$. von Wiese streeft naar een sociologie die op eigen benen kan staan, vrij van zowel biologische als filosofische invloeden. Maar waarom zoveel aandacht voor de opbouw van een gesloten systeem? L. von Wiese heeft altijd de noodzaak van empirisch onderzoek beklemtoond, hij noemt zijn 'Beziehungslehre' nadrukkelijk een empirisch-systematische sociologie. Pogingen om zijn theorie daadwerkelijk aan de empirie te toetsen onderneemt hij echter nooit. In plaats daarvan stuurt hij zijn studenten bij voorbeeld naar een dorp om daar aan de hand van de 'Beziehungslehre' de sociale processen te observeren en te catalogiseren. Waarom vindt $L$ von Wiese dit sociologisch botaniseren' ${ }^{\text {'9 }}$ belangrijker dan maatschappelijk relevant onderzoek? Waarom steekt de stad Keulen hier zonder morren geld in? Als L. von Wiese slechts een 'inhoudsloos' systeem schiep, hoe kon hij dan uitgroeien tot een bekend socioloog? Een tijdgenoot bericht zelfs: 'Damals sprach man in Deutschland mehr über L. von Wiese als von Max Weber."20

Laten we, alvorens een antwoord te zoeken op deze vragen, ons eerst een moment verplaatsen naar de kamer die op het Keulse onderzoeksinstituut grenst aan die van $L$. von Wiese. Hier zetelt Max Scheler, de tweede directeur van de sociologische afdeling. Terwijl Von Wiese zijn 'Beziehungslehre' opstelt, werkt Scheler een deur verder aan zijn kennissociologie, een onderneming die niet minder tot de rariteiten van de moderne sociologie is gaan behoren. De 'Wissenssoziologie' die Scheler bedrijft, wijkt dan ook af van wat men na de tweede wereldoorlog onder kennissociologie is gaan verstaan. Scheler ontwerpt geen onderzoeksprogramma, maar, evenals $\mathrm{L}$. von. Wiese, een leer. De bedoeling die Scheler met deze leer heeft, heeft hij in 1921 duidelijk uiteengezet in een programmatisch artikel dat verschijnt in het eerste nummer van het (mede) door $L$. von 
Wiese opgezette tijdschrift Kölner Vierteljahreshefte für Soziologie und Sozialwissenschaften. De oorspronkelijke titel verraadt al Schelers program: 'Die positivistische Geschichtsphilosophie des Wissens und die Aufgaben einer Soziologie der Erkenntnis;. De opgaven van de kennissociologie bestaan volgens Scheler in de eerste plaats uit het corrigeren van de 'ganz tiefen Irrtümer' van het positivisme, waarbij met name de driestadiawet van Comte het moet ontgelden. Scheler bestrijdt dat kennisvormen in een historische hiërarchie zouden staan, zoals Comte stelt. Religie, metafysica en positieve wetenschap hebben zich 'gleich ursprünglich aus dem mythischen Denken voneinander abdifferenziert'. Het positivisme begaat een 'onmetelijke vergissing' door wetenschap tot de maat van alle kennis te maken, want: 'Es sind drei völlig verschiedene Motive, drei völlig verschiedene Gruppen von Akten des erkennenden Geistes, drel verschiedene Ziele, drei verschiedene Persönlichkeiltstypen und drei verschiedene soziale Gruppen, auf denen Religion, Metaphysik und positive Wissenschaft beruhen'. ${ }^{21}$

In Probleme einer Soziologie des Wissens, dat drie jaar later verschijnt, doet Scheler een poging deze stelling historisch uit te werken. Naast een typologie van kennisvormen en hun specifieke ontwikkelingswetten presenteert hij in dit werk nog een tweede ordeningssysteem, dat de historische verhouding tussen Geest (Idealfaktoren) en Werkelijkheid (Realfaktoren) tot onderwerp heeft. In dit geval zijn het vooral de "tiefen Irrtümer' van zowel het idealisme als het (historisch) materialisme die gecorrigeerd worden. De Geest, het denken, ontwikkelt zich volgens Scheler autonoom, maar willen ideeën ook betekenis en invloed krijgen in het maatschappelijk leven, dan dienen ze zich te verbinden met reële krachten. Deze krachten, de Realfaktoren, rubriceert Scheler vervolgens in drie typen (Blut, Macht, Wirtschaft), waarbij elk type correspondeert met een bepaald type van menselijke driften (Sexual- und Fortpflanzungstriebe, Machtstriebe, Nahrungstriebe). Langs deze weg komt Scheler viteindelijk tot het opstellen van een historische wet: in achtereenvolgende fasen van de menselijke geschiedenis functioneren respectievelijk Blut, Macht en Wirtschaft als de primaire "sluizen" waarlangs bepaalde delen van de geestesstroom maatschappelijk gewicht kunnen krijgen. ${ }^{22}$

Het behoeft ons niet te verbazen dat er van intellectuele gedachtenuitwisselling tussen de bejde directeuren van de sociologische afdeling van het Keulse onderzoeksinstituut geen sprake was. Daarvoor waren de verschillen te groot. De wat stugge Pruis $L_{\text {w von }}$ Wiese, die van de sociologie juist een positieve wetenschap wou maken, was de antipode van de flamboyante Scheler, die ook in zijn sociologisch werk bleef wat hij sinds zijn bekering was: een katholiek cultuurfilosoof. Maar ofschoon beiden binnen de muren van het sociaal-wetenschappelijke instituut hun eigen systeem opbouwden, trad de sociologische afdeling naar buiten toe altijd als een eenheid op. Ze publiceerden beiden in het huistijdschrift, de al genoemde Kölner Vierteljahreshefte, en nodigden elkaar zelfs uit voor het leveren van bijdragen aan themanummers van dit periodiek.

\section{Geïnstitutionaliseerd dilantisme?}

In meerdere opzichten kan het Keulse instituut model staan voor de Weimarsociologie als geheel. De manier waarop Scheler en $\mathrm{L}$. von Wiese sociologie beoefenden vinden we terug bij collega's als Oppenheimer, Vierkandt, Alfred Weber, Plenge en Freyer. Al deze heren werkten aan een eigen theoretisch systeem, ontwierpen een eigen begrippenapparaat, en stichtten zo mogelijk een eigen school; een situatie kortom, die Sombart 
eens vergeleek met een roofriddersysteem. ${ }^{23}$ Deze grote onderlinge verdeelldheid weerspiegelt voor een deel de sterke politieke verdeeldheid in de republiek van Weimar. Bovendien kan men wijzen op de neergang van de kantiaanse filosofie na de eerste wereldoorlog. Het filosofische spectrum verbreedde zich aanzienlijk en deze versnippering werkte onmiddellijk door in de sociologie. Desalniettemin presenteerden deze academici de sociologie naar buiten toe als én discipline, bij voorbeeld als het erom ging de sociologie als universitair hoofdvak ingevoerd te krijgen. Onder leiding van met name L. von Wiese profileerde de Deutsche Gesellschaft fur Soziologie zich in dat kader ook steeds meer als een beroepsvereniging. Ondanks de interne richtingenstrijd deed men alle moeite het vak een collectieve identiteit te verschaffen.

De presentatie van de sociologie als een zelfstandige discipline wierp bovendien haar vruchten af. Het ging de sociologie in de vijftien jaar die de republiek van Weimar stand hield redelijk voor de wind. Het aantal ordinariaten met sociologie in de leeropdracht nam sterk toe (van drie in 1918 naar zeventien in 1930), er kwamen vier nieuwe sociologische tijdschriften uit; tussen 1918 en 1933 verschenen er zesendertig sociologische leerboeken en een omvangrijk Handwöterbuch der Soziologie; in dezelfde periode werden vijf onderzoeksinstituten opgericht, waaronder dat in Keulen. ${ }^{24}$ Kortom, met enig recht kon L. von Wiese in 1929 opmerken: "Die Soziologie "marschiert" trotz aller äusseren und inneren Schwierigkeiten ${ }^{25}$, hoe wrang de beeldspraak achteraf ook is.

De schaduw die de latere disciplinegeschiedenis over de Weimar-episode werpt, stelt wetenschapshistorici als de al eerdergenoemde Schad voor het probleem dat de activiteiten van Scheler, L. von Wiese en hun collega's niet overeenstemmen met de ontwikkelingsfase van een discipline. Terwijl het vak zelf reeds is geïnstitutionaliseerd in hoogleraarsposten, onderzoeksinstituten, tijdschriften en leerboeken, heeft het gedrag van hen die het vak beofenen veel weg van de dilettant, van iemand dus die thuishoort in een eerder stadium van de wetenschapsontwikkeling. Dit type immers ordent, classificeert en ontwerpt zo mogelijk een eigen systeem, zoals Spencer dat bij voorbeeld deed. Het wetenschapshistorisch probleem waarmee men met andere woorden wordt geconfronteerd, is dat in dit geval institutionalisering en professionalisering niet gepaard gaan met het ontstaan van een onderzoekstraditie dat door een collectief vocabulaire gedragen wordt. Veel literatuur over de hoofdstroom van de Weimarsociologie doet een poging deze anomalie te verklaren. Laten we de belangrijkste verklaringen kort langs lopen.

In de eerste verklaring die we in de literatuur aantreffen, wordt erop gewezen dat de sociologie haar vestigingsstrijd in de Weimarperiode onder ongunstige condities voerde. Voor een eigen plaats onder de academische zon was nauwelijks ruimte, omdat enerzijds in Duitsland de sociologische optiek aan vakken als economie en geschiedenis niet vreemd was, terwijl anderzijds de statistiek zich hier tot een aparte empirische sociale wetenschap had ontwikkeld. Voor de sociologie bleef derhalve weinig anders over dan het scheppen van theoretische systemen. ${ }^{26}$ Deze verklaring is echter op zijn minst onvolledig omdat bij deze voorstelling van zaken sociologen slechts pasșief lijken te reageren op de externe (academische) omgeving. In de tweede verklaring die we kunnen onderscheiden, wordt wel rekening gehouden met de intenties van de betrokkenen zelf. Het ging de Weimarsociologen er vooral om de sociologie als leervak ingevoerd te krijgen, vandaar hun nadruk op systeembouw. ${ }^{27}$ Ook deze verklaring overtuigt niet en wel omdat men toch veronderstellen mag dat achter dit oogmerk, naast directe belangen, 
ook intellectuele motieven schuilgaan. Daarover zwijgt de verklaring evenwel. Een derde type verklaring besteedt wel aandacht aan zulke motieven. Men wijst erop dat de sociale wetenschap in Duitsland altijd al sterk filosofisch georienteerd is geweest. In de sociologie werd zo bezien de geesteswetenschappelijke traditie gewoon voortgezet. ${ }^{28}$ Bevredigend kan ook deze verklaring niet zijn, omdat ze niet specifiek genoeg is. Zoals bekend verloor onder intellectuelen de conservatief-burgerlijke traditie in de republiek van Weimar nauwelijks aan kracht. De meeste beoefenaren van de sociologie staan inderdaad in deze traditie. Desondanks streefde men daarbinnen naar een eigen plaats voor de sociologie. Waarom bleven $L$ von Wiese en Scheler niet wat ze voorheen waren, namelijk respectievelijk econoom en filosoof? Door te wijzen op de filosofische oriêntatie en op de gemeenschappelijke ideologie van de traditionele Duitse intelligentsia wordt anders gezegd niet duidelijk welke specifieke bedoelingen er schuilgaan achter de wijze waarop de sociologiebeoefening in de republiek van Weimar gestalte krijgt. Zo zijn we terug bij de eerste verklaring.

Alle drie typen verklaringen lijden aan hetzelfde manco. Ze gaan ervan uit dat de sociologiebeoefening in de Weimarperiode niet haar normale loop nam. Willen we dus een stap verder zetten, dan lijkt het raadzaam juist deze veronderstelling te laten vallen. Misschien deden sociologen als L. von Wiese en Scheler juist wel onderzoek van het hoogste belang, niet alleen in hun eigen ogen, maar ook naar de mening van een bepaald, voor hen relevant publiek. Is dit het geval, dan is ook een ander probleem oplosbaar. Door uitsluitend oog te hebben voor de variatie in vocabulaire en de interne verdeeldheid die onder sociologen heerste, moet men de binding tot een discipline wel louter toeschrijven aan externe factoren. Wellicht ontbrak het de toenmalige discipline echter helemaal niet aan interne eenheid, maar had de identitelt van het vak alleen een ander karakter dan men op grond van bij voorbeeld de ontwikkeling van de sociologie in de Verenigde Staten zou verwachten.

\section{De culturele taak van de Weimarsociologie}

De republiek van Weimar wordt, zoals bekend, niet onder een gunstig gesternte geboren. $\mathrm{Na}$ de eerste wereldoorlog wordt de nieuwe republikeinse overheid niet alleen met allerlei politieke en economische problemen geconfronteerd, ook betwisten velen de legitimiteit van de democratische staat. De coalitiekabinetten van confessionelen en sociaal-democraten proberen deze oppositie de wind uit te zeilen te nemen door het voeren van een nieuwe onderwijs- en cultuurpolitiek. In de beginjaren van de republiek van Weimar worden op dit terrein ook enige (aarzelende) hervormingen doorgevoerd. Zo hoopte men via het oprichten van pedagogische academies de kwaliteit van het onderwijs te verbeteren. Naast het aanbrengen van organisatorische vernieuwingen probeert men een aanzet te geven tot innere Reform' binnen de bestaande onderwijsinstellingen. $\mathrm{Zij}$ zouden systematisch aandacht moeten besteden aan de vorming van een republikeinse gezindheid. De lijn woor deze - achteraf gezien weinig succesvolle - politiek werd uitgezet door C.H. Becker, de man die tot 1930 het zogenaamde "Kultusministerium' leidde. ${ }^{29}$ 
Niet sociaal-economische maatregelen, maar niet-partijpolitiek georiênteerde cultuurpolitiek ziet Becker als het middel om de verdeelde natie onder een democratische noemer te brengen. Tegenstellingen zouden via pedagogische weg te verkleinen zijn. Het gaat Becker vooral om het scheppen van een nieuwe culturele eenheid, die het wijdverbreide 'geistige Partikularismus' zou kunnen overwinnen. Hierbij ziet hij voor de universiteit een belangrijke taak weggelegd, Ook zij zou tot de vorming van republikeinse staatsburgers moeten bijdragen, wat volgens Becker alleen goed mogelijk is als ook binnen de wetenschap het 'particularisme' wordt ingedamd. Geheel in de geest van Humboldt wil Becker de eenheid van Bildung en wetenschap herstellen. Binnen deze hervormingsvoorstellen nu ruimt Becker voor de sociologie een speciale plaats in. "Wo muss die Reform einsetzen?" vraagt Becker zich af in Gedanken zur Hochschulreform: Der Wille zur Synthese muss wieder erwachen. (...) Wichtig wird es sein, das synthetische Denken der Studenten zu wecken durch Einfügung von Lehrfächern, die ihrem Wesen nach mehrere Disziplinen umfassen. Unsere Wissenschaften verlaufen bisher senkrecht nebeneinander in Parallelen, die sich erst in der Unendlichkeit schneiden. Wir brauchen Fächer, die waagrecht die Senkrechten überschneiden'.30

Tegen de achtergrond van deze gedachte houdt Becker een pleidooi voor de sociollogie: 'Soziologie entspricht eben nicht dem deutschen Denken, weil sie überhaupt aus Synthese besteht. Um so wichtiger ist sie für uns als Erziehungsmittel. Soziologische Lehrstühle sind eine dringende Notwendigkeit für alle Hochschulen. Dabei ist die Soziologie im weitesten Sinne des Wortes gedacht einsliesslich der wissenschaftichen Politik und der Zeitgeschichte. (...) Durch soziologische Betrachtung allein kann auf intellektuellem Gebiet die geistige Gewöhnung geschaffen werden, die dann, auf das ethische Gebiet ubertragen, zur politischen Überzeugung wird. So werde die Wissenschaft für uns der Weg vom Individualismus und Partikularismus zum staatsbürgerlichen Charakter".

De sociologie krijgt hier een culturpolitieke taak toegewezen. Het belang van het vak ligt voor Becker niet in de eerste plaats daarin dat zij de kwaliteit van de sociaaleconomische politiek zou kunnen verbeteren, Sociologie is geen beleidsinstrument, maar opvoedingsmiddel. Zo bezien is het niet verbazingwekkend dat de sociologie, al is ze niet empirisch gericht, in de republiek van Weimar toch de wind in de zeilen krijgt. Van de nieuwe discipline wordt geen detailkennis verwacht, mar overzicht en zingevende orientatie. Het is niet zo dat de sociologische gemeenschap zich zonder meer achter de humboldtiaanse idealen van minister Becker schaart. Tönnies en Scheler achten het oude idee van de universitas niet meer toegesneden op de moderne tijd. ${ }^{32} \mathrm{~L}$ von Wiese ageert zelfs heftig tegen Beckers beeld van de sociologie. Voor hem is de sociologie immers geen synthetiserende wetenschap, maar een specialisme naast andere vakken. Ondanks deze kritiek verschilt men echter op een meer principieel punt niet met Becker van mening: de sociologie heeft ook in de ogen van deze mannen een cultuurpolitieke taak. Wat hen hier met Becker verbindt, is vooral dat zij eenzelfde visie op de democratie hebben als hij.

L. Von Wiese, Scheler en ook het merendeel van hun collega's zijn in politiek opzicht verwant aan de 'Weimarer Kreis', een door de historicus Meinecke opgericht verbond van verfassungstreuer Hochschullehrer'. Deze organisatie weet maar een minderheid van de academici aan zich te binden en bestaat, maast een enkele sociaal- 
democraat, voornamelijk uit burgerlijk-liberale "Vernunftrepublikaner". De democratieopvatting van deze intellectuelen heeft een sterk aristocratisch karakter. Intellectuelen zouden binnen de republiek niet alleen een leidende functie moeten vervullen, maar hadden daarnaast ook een opvoedende taak. De gevormde elite zou de ongevormđe massa moeten inwijden in het Duitse cultuurgoed, in de traditie van het "Bildungsbürgertüm'. De culturele eenheid moest na de Novemberrevolutie en de Kappputsch worden hersteld en dat zou moeten gebeuren door met name de arbeidersbeweging en de rechts-nationalistische jeugdbeweging via vorming en scholing in de republiek te integreren. ${ }^{33}$ Binnen de context van deze democratieopvatting worden maatschappelijke en politieke problemen snel gepercipieerd als cultuurpolitieke opvoedingsproblemen. Zonder het inhoudelijk in alle opzichten met Becker eens te zijn, nemen bijgevolg ook veel sociologen aan dat ze de taak van hun wetenschap primair in culturele en didactische termen moeten definiëren.

Deze taakopvatting is te bekritiseren door het democratieconcept waarop ze berust te verwerpen. Naast deze politieke kritiek vinden we in disciplinegeschiedenissen van de sociologie vooral wetenschappelijke kritiek op de met deze taakopwatting verbonden praktijk. De Weimarsociologen (of althans diegenen onder hen die toentertijd voor de sociologiebeoefening gezichtsbepalend waren) zouden het contact met de werkelijkheid verloren hebben. Hiermee zegt men echter alleen dat wij het contact met hun werkelijkheid en met hun praktijk verloren hebben. Met name over de praktische orientatie van deze sociologen wordt niet meer gerept.

Was er dan een bepaalde praktijk waar deze sociologen zich op konden orienteren? Want sociologie kan slechts daadwerkelijk een culturele taak vervullen indien er ook een of andere adressant beschikbaar is. Contact met de arbeidersbeweging was er niet, daarover sprak men alleen. Ook tot de politieke partijen of hun jeugdbewegingen hadden sociologen in de republiek van Weimar nauwelijks toegang. Er was evenwel een belangrijk alternatief voorhanden: de volkshogeschool.

\section{Een praktijk voor sociologen: de volkshogeschool}

Het verschijnsel 'volkshogeschool' is een Deense uitvinding. In het midden van de worige eeuw verzette de theoloog Grundtvig zich tegen het rationalistische humanisme dat destijds het onderwijs beheerste. De studie van Grieks en Latijn doodde volgens Grundtvig de levende omgang met God en vergrootte bovendien de kloof tussen de gevormde elite en het gewone volk. In de door hem opgerichte 'Volksheimschulen' zou die band weer hersteld moeten worden. Hier werd dan ook niet gedoceerd, maar gingen, in een natuurlijke omgeving, vorming en beleving hand in hand. ${ }^{34}$

Anders dan in Denemarken krijgt in Duitsland de volkshogeschoolgedachte pas in en vooral na de eerste wereldoorlog brede aanhang. Volkshogescholen, in dit geval voornamelijk avondscholen in de steden, schieten na de oorlog als paddestoelen uit de grond. Zo worden er in 1919 honderdvijfendertig volkshogescholen gesticht en in 1929 bestaan in de republiek van Weimar in totaal tweehonderdvijftien van zulke, naar eigen zeggen in levensbeschouwelijk en politiek opzicht neutrale instituten. ${ }^{35}$ Waar ging het deze scholen om?

In het leerplan van de 'Freie Volkshochschule Hamburg' uit de jaren twintig lezen we: 'Die Volkshochschule dient der Bildung des gesamten Volkes und will den gesell- 
schaftlichen Fortschritt fordern. Sie wendet sich an den Menschen als Staatsbürger und als Mitglied der Kulturgemeinschaft seines Volkes. (..) Die Volkshochschule steht nicht im Dienst einer bestimmten Weltanschauung ođer einer Partei. Es ist Sache des Hörers, sich zu entscheiden. Dem Wesen einer Hochschule würde es weiter auch nicht entsprechen, wenn die Volkshochschule sich auf die Übermittlung fertigen Wissens beschrảnkte. Auf das Selbstdenken und das unablässige Streben nach Vertiefung der eigenen Erkenntnis komt es an ${ }^{36}$

Deze woorden zijn kavakteristiek voor de volkshogeschoolbeweging als geheel. Niet alleen in Hamburg maar ook elders worden Grundtvigs intenties verbonden met de idealistische Bildungstraditie. ${ }^{37}$ Ondanks banden met de modern-romantische jeugdbeweging is het doel van de Volkshogeschoolbeweging toch meer de vorming van een 'Bildungs und Kulturgemeinschaf' dan van een 'Volksgemeinschaft'. Weliswaar is het een sterk aristocratisch gekleurd ideaal, maar van een antirepublikeinse ondertoon is over het algemeen geen sprake. Evenals Becker meent men dat sociale conflicten tussen maatschappelijke groeperingen langs cultureel-pedagogische weg tot een oplossing gebracht kunnen worden. Het ministerie voor Wetenschap en Cultuur had dan ook hooggespannen verwachtingen van de Volkshogeschoolbeweging. Zij die dat ook hadden waren de sociologen.

Tussen de Weimarsociologie en de Volkshogeschoolbeweging bestaan vele persoonlijke banden. Om er enkele te noemen: Vierkandt, redacteur van het eerste Duitse sociologische woordenboek en hoogleraar te Berlijn, is medeoprichter van de Berlijnse volkshogeschool; Oppenheimer, de man die voor zijn sociologisch systeem tien banden nodig had, is naast hoogleraar te Frankfurt nauw betrokken bij de joodse volkshogeschool aldaar; Plenge, die als hoogleraar sociologie te Münster voortbouwt op Wieses Beziehungslehre, organiseert eigen volksopvoedingscursussen; $L$, von Wiese is vele jaren actief op het gebied van de volksopvoeding en neemt in 1918 zelfs het initiatief tot de oprichting van de Keulse volkshogeschool. Naast de banden tussen deze hoogleraren en de volkshogescholen verdient bovendien vermelding dat veel van hun studenten op het terrein van de volksopvoeding werk vinden. Veel studenten van Freyer zijn in en rondom Leipzig op dit terrein actief. Voor de kring rondom $L$. von Wiese geldt hetzelfde. $\mathrm{ZO}$ is de wetenschappelijke assistent van $\mathrm{L}$ von Wiese, Honigsheim, tevens directeur van de volkshogeschool in Keulen. ${ }^{38}$

Deze nauwe relatie tussen sociologen en de in de republiek van Weimar invloedrijke Volkshogeschoolbeweging hoeft ons niet te verbazen. Actuele maatschappelijke vraagstukken worden immers door veel sociologen geinterpreteerd als cultureel-pedagogische problemen. De praktische taak van hun sociologie is cultureel van aard, zij het dat ze er niet uit bestaat een bijdrage te leveren aan de publieke meningsvorming (daarvoor zou een democratieopvatting nodig zijn die een intellectuele elite niet boven de 'massa' verheft), ze had veeleer een aristocratisch en pedagogisch karakter. Deze takkopvatting spoort ook met de praktijkoriëntatie en het beroepsperspectief van deze groep sociologen. $\mathrm{Zij}$ komen niet in overheidsdienst en worden ook niet, zoals Max Weber, politiek actief.

In 1927 publiceert de socioloog Walther, na een rondreis door de Verenigde Staten, het boekje Soziologie und Sozialwissenschaften in Amerika und ihre Bedeutung für die Pedagogik. Deze toevoeging 'en hun betekenis voor de pedagogiek' drukt niet alleen 
Walthers persoonlijke preoccupaties uit. Hij kon ervan uitgaan dat veel van zijn collega's de relevantie van sociologisch werk in hoge mate verbonden met de betekenis ervan voor de pedagogische praktijk. ${ }^{39}$

\section{Terug naar Keulen}

Vanuit het gezichtspunt van de latere disciplinegeschiedenis verschijnen de activiteiten die $\mathrm{L}$. von Wiese en Scheler op hun Keulse onderzoeksinstituut ondernemen als te verklaren anomalieèn. Plaatsen we hun werk daarentegen meer in thaar toenmalige lokale context, dan blijkt wellicht dat zij precies deden wat van hen als socioloog werd verwacht. Daarvoor pleit bij voorbeeld de keuze van het onderwerp van de eerste band in de serie Schriften des Forschungsinstituts für Sozialwissenschaften in Köln, verschenen in 1921. Onder de titel Soziologie des Volksbildungswesens zijn hierin opstellen verzameld die het gehele veld van de toenmalige volksopvoeding bestrijken. We vinden theoretische bijdragen van zowel $L$. von Wiese als Scheler, overzichtsartikelen waarin de stand van zaken in Duitsland en in andere landen wordt besproken, bijdragen uit 'het veld', enzovoort. ${ }^{40}$ Vanuit de bovengenoemde culturele taakopvatting hoogst actueel en relevant onderzoek dus.

Zou, zo moeten we tenslotte vragen, voor het theoretische werk van L. von Wiese en Scheler niet hetzelfde gelden? Wanneer het mogelijk is aan te tonen dat deze qua filosofische en wetenschappelijke achtergrond zo total verschillende theorieen zijn toegesneden op dezelfde (pedagogische) praktijk, dan is wellicht tevens het probleem oplosbaar wat, bij alle interne verdeeldheid, de Weimarsociologie toch een eigen gezicht, een eigen identiteit heeft verschaft. Laten we de 'Beziehungslehre' van $L$. von Wiese en de 'Wissenssoziologie' van Scheler nog eens bezien.

In Schelers verzameld werk is het oorspronkelijke voorwoord bij zijn Probleme einer Soziologie des Wissens weggevallen. Juist in dit voorwoord spreekt Scheler zijn bedoelingen echter duidelijk uit. De kennissociologie noemt Scheler hier het fundament voor alle rationele cultuurpolitiek. In deze vorm van sociologie, zo vervolgt hij, "finden alle kulturpolitischen Probleme uber Entwicklung, Reform, Leitung, Zielsetzung und Verwaltung der Institutionen, die unser menschliches Wissen zu fördern und zu verbreiten berufen sind - seien es Universitaten, Volkshochschulen, Akademien, Vereine, ubernationale Körperschaften usw. -, ein einheitliches Forum der Aussprache und der Erörterung, und gleichzeitig höchste und letzte Massstăbe für ihre Gestaltung und für die beste Art und Weise ihrer sinnvollen Kooperation zur Gesamuforderung des dem Menschen zugänglichen Wissens' ${ }^{41}$

Cultuurpolitiek moet een wetenschappelijke grondslag hebben, vindt Scheler. Universiteitshervormingen, volksopvoeding en dergelijke dingen meer zijn volgens hem geen (partij)politieke problemen, maar kennissociologische kwesties. Wie cultuurbeleid wil voeren dient dan ook niet naar politieke maatstaven te handelen, hij zal de kennissocioloog moeten raadplegen. Dat de kennissociologie bij Scheler in een cultuurpolitieke context staat en een duidelijke pedagogische functie heeft, verheelt hij allerminst, zoals het citaat al aangeeft. Ook in zijn kritiek op de drie-stadiawet van Comte is het Scheler uiteindelijk te doen om een cultuurpolitieke gevolgtrekking. Nadat hij heeft geconcludeerd dat religie, metafysica en positieve wetenschap toch geheel verschillende kennisvormen zijn, besluit Scheler het artikel met de volgende opmerking: 'Daraus folgt als 
praktische Forderung für den Aufbau der Bìldungsorganisationen eines jedes Volkes, dass in einem solchen Aufbau nicht eine einseitige Ausbildung in einer der Richtungen dieser Erkenntnisarten, sondern eine harmonische Ausbildung in allen gegeben werden muss:. ${ }^{42}$ Kennissociologie en cultureel-pedagogische politiek liggen bij Scheler dïrect in elkaars verlengde, zo kunnen we concluderen.

Bij $L$ von Wiese lijkt een dergelijke nauwe band tussen Bildung en wetenschap moeilijker aanwijsbaar. Een aanval op het positivisme, zoals Scheler die ondernam, vinden we bij hem niet. Niettemin is ook zijn 'Beziehungslehre' toegesneden op de cultureel-pedagogische volksopvoeding. Maar om dat in te zien moeten we eerst even een blik werpen op Wieses denkbeelden aangaande deze praktijk.

$\mathrm{Na}$ de eerste wereldoorlog, zo merkt L. von Wiese in Soziologie des Volksbildungswesens op, lijkt het of wij een nieuw Kanaän betreden, een land waarin de 'Unterklasse' zichzelf voor mondig heeft verklaard. Nu wil L. von Wiese zich daarover niet beklagen, maar wel vreest hij dass die vom Marxismus behauptete Spannung von Bourgeoisbildung und Proletarierbildung zum grössten Aberglauben der Zeit wird'. Tegen zo'n tweespalt verzet $L_{\text {. }}$ von Wiese zich: "Es gibt nur eine Einheit im Geiste!" Dass sie sich in der Erkenntnis aller denkenden Volksgenossen verwirkliche, das ist die notwendige Aufgabe unserer Generation!. Het beste instrument hiervoor is uiteraard de volksopvoeding. 'Die Volksbildung muss Kraft zu einer neuen Gemeinschaft, die über den Klassengegensätzen steht, erzeugen. Die ungeheure Aufgabe, der inneren Zerspaltung des Volkes in Ober- und Unterklasse zu begegnen, wird man gleichfalls obenan stellen müssen' Concreet betekent dit dat op de volkshogescholen bij de persoonlijke vorming ideologieen of wereldbeschouwingen geen rol mogen spelen. De deelnemers moeten inzicht krijgen in de reele betrekkingen tussen mensen, dat wil zeggen ze zouden antwoord moeten krijgen op vragen als. "Was verhilft mir zu einem die Zusammenhänge überschauenden Verständnisse meiner Stellung und meiner Arbeit in der Welt, in meinem Volke und meinem engeren Lebenskreise? Was sind wir Menschen einander? Welche Notwendigkeiten beherrschen mein Leben?:43

Precies op dit type vragen beoogt de 'Beziehungslehre' een antwoord te geven. Wij willen, zo schrijft $\mathrm{L}$. von Wiese in zijn hoofdwerk System der Allgemeinen Soziologie "durch den Wust von Theorien, Philosophien, Ideologien, Utopien (...) hindurchstossen zu den Menschen, ihrem Leid, ihrem Glück. Wir wollen (...) die Augen öffnen für die Verflechtungen ihrer Schicksale, für das Verhältnis von Du und Ich, Wir und Ihr: ${ }^{44}$ In praktisch opzicht was de 'Beziehungslehre' volgens $L$. von Wiese dan ook niets minder dan 'Menschenkunde'. Het ontwerpen van een abstract systeem, waarin een quasi exacte terminologie wordt ingevoerd ( $\mathrm{L}$. von Wiese deelt bij voorbeeld menselijke betrekkingen op in A-, B-, C-, D-, E- en F-processem) lijkt hiermee op het eerste gezicht in strijd. Maar voor $\mathrm{L}$. von Wiese is er helemaal geen sprake van een tegenstelling. In het voorwoord bij de tweede oplage van zijn hoofdwerk geeft hij critici die zijn leer levensvreemd" noemden het volgende antwoord. Wat mijn critici in werkellijkheid missen, zo stelt $\mathrm{L}$. von Wiese, is de omgang met de hun zo geliefde "ismes": 'Was bedeutet ihnen eine Soziologie, in der überhaupt nicht von Kapitalismus, Sozialismus, Kommunismus, Liberalismus, Konservatismus usw. usw. die rede ist, diese Ideologiesysteme vielmehr geflissentlich gemieden werden? Diese "Unvollständigkeit" ist allerdings gerade eine Hauptabsicht und Grundregel meines Versuchs. (..) Die Beziehungslehre wird als 
lebensfremd herabgesetzt, weil sie keiner der die Praxis beherrschenden Ideologien dienstbar ist, sondern dem gelebten Leben dadurch nützen möchte, dass sie es recht genau aus unmittelbarer Nähe, aber ohne die Ideologienbrille beschaut: 45

Wie het volk niet wil onderdompelen in ideologische vooroordelen, maar het een ondogmatisch en realistisch inzicht in de menselijke betrekkingen wil bijbrengen, moet dus te rade gaan bij de 'Beziehungslehre', zo blijkt. Het is precies deze leer die in een wereld vol tweedracht eenheid kan scheppen. Wie L. von Wieses intenties wil begrijpen zou in dit verband het motto dat hij aan zijn hoofdwerk meegeeft, niet moeten overslaan: 'Ach, warum fühlen wir das ungeheure Neben-Einander der Welt immer als ein Gegen-Einander?!' (Werfel). In de eerste onderzoeksbundel van het Keulse instituut brengt $L$. von Wiese het doel van zijn werk zelf als volgt onder woorden: "Unsere ganze Arbeit steht in jedem ihrer Teile im Dienste der einzigen Aufgabe: wie können wir zueinander kommen, um uns recht zu verstehen? ${ }^{46}$ Het schrijven van een boek waarin alle menselijke betrekkingen overzichtelijk geordend worden, was een deel van deze opgave.47

\section{Demarcatie van de sociologie: continuïteit en discontinuïteit}

Ondanks de praktische inslag van zijn sociologie heeft $L$. von Wiese herhaaldelijk Webers waardevrijheidspostulaat onderschreven. ${ }^{48} \mathrm{Zijn}$ oppositie tegen de oorspronkelijke statuten van de sociologievereniging had in zijn eigen ogen dan ook meer een praktische dan een principiele achtergrond. Weber interpreteerde het waardevrijheidsgebod zo strikt en nam op de eerste twee sociologieconferenties zo'n strenge houding aan, dat veel deelnemers nauwelijks meer vrijuit durfden te spreken, meende $L$. von Wiese. Toch blijkt uit de manier waarop L. von Wiese gestalte geeft aan de maatschappelijke rol van de sociologie, dat zijn interpretatie van het waardevrijheidsprincipe meer aansluit bij het gedachtengoed van Schmoller. De autonomie van de sociologie krijgt bij hem immers gestalte door haar een onpartijdig karakter toe te meten. Terwijl de wereld in de ban dreigt te raken van eenzijdige ideologieën, staat de socioloog boven de partijen. Hij distantieert zich van de strijd tussen levensbeschouwingen en politieke stromingen door zich te richten op 'de realiteit zelf, dat wil zeggen: op datgene wat mensen samenbindt, niet wat hen verdeelt.

Deze verwantschap met Schmoller komt ook tot uitdrukking in de demarcatiearbeid die $L_{\text {. }}$ von Wiese verricht. Sociologiebeoefening is naar zijn mening onverenigbaar met het bedrijven van partijpolitiek en hij benadrukt dientengevolge de afstand tussen 'sociologie' en maatschappijkritiek. In dit kader stelt hij ook alles in het werk om de sociologische vereniging te 'zuiveren' van met name marxistisch georiënteerde sociologen.

Toch verschilt Wieses doen en laten op een aantal punten met Schmollers demarcatiearbeid. Een daarvan is zoeven al aangestipt: $L$. von Wiese verklaart het waardevrijheidsideaal in principe te onderschrijven. Om Wieses positie te kunnen begrijpen, is het goed te beseffen dat sociologen zich na Webers dood niet en masse tegen hem hebben gekeerd, zoals het standaardbeeld van de Weimarsociologie suggereert. Webers werk en ook zijn methodologische inzichten blijven voor veel beoefenaren van de sociologie richtinggevend. ${ }^{49} \mathrm{Zo}$ accepteren $\mathrm{L}$. von Wiese en zijn geestverwanten Webers opvatting dat het waardevrijheidsprobleem primair als een methodologisch vraagstuk dient te 
worden beschouwd. Tussen feiten en waarden gaapt een logische kloof, meent ook $\mathrm{L}$. von Wiese.

Deze methodologische stellingname heeft een belangrijke verandering in het zelfbeeld van veel wetenschapsmensen met zich meegebracht. Academici als Schmoller en Herkner waren nog in staat openlijk te erkennen dat de menswetenschappen zich in praktisch opzicht orienteren op de 'hoge' waarden van het nationale belang. Doordat het waardevrijheidsprobleem nu een weberiaans stempel krijgt, wordt het echter minder goed mogelijk de cultuurpolitieke rol van de sociologie met een beroep op (praktische) waarden te rechtvaardigen. Het zelfbeeld van $L$. von Wiese (maar ook van sociologen als Scheler) krijgt er een meer 'scientistisch' karakter door: men doet alsof hun cultuurpolitieke orientatie louter op wetenschappelijke inzichten is gestoeld. Webers invloed werkt hier dus averechts; zijn waardevrijheidsprincipe dient niet meer een restrictionistisch doel, maar gaat fungeren als dekmantel voor een expansionistische wetenschapspraktijk. ${ }^{50}$ Deze omgang met Webers waardevrijheidsprincipe heeft op haar beurt weer tot een andere uitleg van dit principe geleid.

Amerikaanse sociologen van na de tweede wereldoorlog, zo is in het vorige hoofdstuk geconcludeerd, interpreteren Webers waardevrijheidsgebod vanuit een Amerikaanse invalshoek. Omdat in de Verenigde Staten de opkomst van de sociologie meteen in het teken stond van professionalisering en disciplinevorming, neigen zij ertoe ook Webers waardevrijheidsgebod in die context te plaatsen. Dit brengt met zich mee dat in hun perceptie het onderscheid met Schmollers onpartijdigheidsprincipe vervaagt. Maar niet alleen in de Verenigde Staten ondergaat Webers demarcatiearbeid dit lot. Reeds eerder gebeurde in de republiek van Weimar iets soortgelijks; academici die zich inzetten voor een professionalisering van de sociologie, vatten het waardevrijheidsprincipe al snel op als een pleidooi voor maatschappelijke eenheid en partijpolitieke neutraliteit. L. von Wiese stond op dit punt zeker niet alleen.

Evenals Schmollers ethische economie kunnen we de in de republiek van Weimar dominante vorm van sociologiebeoefening expansionistisch noemen, ook al onderschrijven veel sociologen, zoals gezegd, nu Webers (geherinterpreteerde) waardevrijheidsgebod. Wanneer we dit expansionisme nader in ogenschouw nemen, stuiten we nog op een andere ontwikkeling. In de $19 \mathrm{e}$ eeuw raken in Duitsland sociale wetenschap en sociale politiek nauw met elkaar verbonden en wanneer in 1872 de Verein für Sozialpolitik wordt opgericht krijgt die relatie ook een institutioneel karakter. Binnen deze vereniging worden de grondslagen gelegd voor een economische crisispolitiek die de negatieve effecten van industrialisering en urbanisering probeert te minimaliseren. Maar terwijl Weber, Simmel, Tönnies en Sombart de studie van economische en sociaal-politieke vraagstukken tot een centraal onderwerp van de sociologie bleven rekenen, raken door de introductie van het waardevrijheidsprincipe de praktische problemen van sociaal beleid bij hun opvolgers meer op de achtergrond. Deze tendens wordt binnen de sociologische vereniging nog eens versterkt doordat invloedrijke leden als $L$. von Wiese, Vierkant en Mannheim de sociologie als een zelfstandige discipline gaan presenteren. Sociologie wordt door hen uit het bredere verband van de politieke en economische wetenschappen gelicht waarin ze in Duitsland oorspronkelijk tot ontwikkeling kwam en krijgt - mede daardoor - een meer cultuurfilosofische inslag. Terwijl Schmoller zich nog richtte op onderwerpen als de prijspolitiek, het ondernemingsrecht en andere vormen 
van sociale wetgeving, komen nu thema's als de culturele rol van intellectuelen, de psychologie van de massa en de fundamentele menselijke betrekkingen op de voorgrond te staan. ${ }^{51}$ Wetenschappelijk expansionisme is derhalve niet langer in hoofdzaak gericht op de "verwetenschappelijking" van de sociaal-economische politiek, maar uit zich nu meer in het streven naar een cultuurpolitiek die op sociologische inzichten is gestoeld.

Small en $L$ von Wiese: een vergelijking

De cultuurpolitieke gedaante die de "officiële" sociologie binnen de republiek van Weimar aanneemt, draagt er toe bij dat veel Duitse sociologen zich anders gaan verhouden tot de Amerikaanse sociologie. De wetenschappelijke en methodologische activiteiten van Max Weber sluiten niet of nauwelijks aan bij de wijze waarop rond de eeuwwisseling in de Verenigde Staten de sociologie wordt beoefend. De dominante vorm van sociologiebeoefening in de republiek van Weimar vertoont daarentegen alsnog cen zekere verwantschap met de academische Amerikaanse sociologie uit die periode. Met name tussen de manieren waarop Albion Small in het laatste decennium van de $19 \mathrm{e}$ eeuw en Leopold von Wiese dertig jaar later de sociologie eèn eigen identiteit proberen te geven, bestaan enkele belangrijke overeenkomsten.

Evenals Small probeert L von Wiese de sociologie te demarqueren met behulp van de metafoor van de diepte. Small zoekt naar de verborgen krachten die het menselijk handelen vorm en inhoud geven, L. von Wiese naar de essentięle betrekkingen tussen mensen. De classificatiearbeid die zij beiden beoefenen, wordt door hen realistisch geïnterpreteerd: zowel Small als $L$. von Wiese vatten hun typologieen op als een weerspiegeling van de sociale realiteit. Beiden hechten ook een groot belang aan descriptie en zetten hun studenten aan tot het maken van sociografische studies van lokale gemeenschappen. Van een kloof tussen hun 'abstracte" en deze "empirische" arbeid is in beide gevallen volgens hen zelf geen sprake; zowel Small als L. von Wiese pretenderen via beide activiteiten het ware karakter van de sociale werkelijkheid bloot te leggen. Hun beider projecten hebben tenslotte een praktische, cultuurpolitieke pointe. $\mathrm{Zij}$ eisen voor de sociologie cultureel gezag op, omdat deze wetenschap bij uitstek in staat zou zijn om tegenwicht te bieden aan de moderne dreiging van toenemende morele, politieke en ideologische verdeeldheid.

Verschillen zijn er natuurlijk ook. De maatschappelijke situatie waarmee zij zich geconfronteerd zien en de intellectuele cultuur waarvan zij deel uitmaken zijn niet dezelfde en dit komt ook in hun werk tot uitdrukking. Zo stelt de Amerikaan Small een groter vertrouwen in de functie van de publieke opinie dan de Duitse 'mandarijn' $L$. von Wiese. Daarnaast verschilt ook de wijze waarop beiden hun project wetenschappelijk legitimeren. Small kende Weber niet, maar met het werk van Schmoller was hij goed bekend. Tot op zekere hoogte stemde Smalls conceptie van de sociologie ook overeen met de manier waarop Schmoller vorm gaf aan de economische wetenschap en de maatschappelijke rol die hij voor deze wetenschap opeiste. L. von Wiese daarentegen houdt noch de economie noch de sociologie voor een ethische wetenschap. Achter zijn 'Beziehungslehre' gaat geen teleologische geschiedfilosofie meer schuil, maar deze beperkt zich, zo meent $\mathrm{L}$ von Wiese, strikt tot de feiten. Anders dan Small meent $\mathrm{L}$. von Wiese bovendien dat de sociologie een eigen, afgebakend object kent. Voor Small is de sociologie, hoezeer hij haar ook als een discipline presenteert, geen wetenschappelijk 
specialisme (al heeft hij later, zo nog blijken zal, zijn mening op dit punt bijgesteld), maar een wetenschap die de inzichten van andere, wel gespecialiseerde sociale wetenschappen samenvoegt tot een reel beeld van de sociale wereld.

Toch vallen deze verschillen tussen het project van Small en dat van $L$. von Wiese in het niet bij het verschil dat op collectief niveau bestaat tussen de vroege Amerikaanse sociologie en de Weimarsociologie. Onder de vlag van 'sociologie' gaat in de republiek van Weimar een veel grotere verscheidenheid van intellectuele activiteiten schuil dan in de Verenigde Staten. Sociologie heeft in Duitsland geen afgebakende betekenis, behalve dan dat het merendeel van de toentertijd bekende sociologen zich oriënteren op de praktijk van de volksopvoeding. Ook in de Verenigde Staten verstaan sociologen onder sociologie' verschillende dingen, maar hun onderlinge band wordt niet alleen door een verwante praktijkorientatie geconstitueerd. Tevens ontplooien zij hun activiteiten tegen de achtergrond van een gezamenlijk vocabulaire.

Alhoewel er tussen de sociologiebeoefening in beide naties meer verschillen aan te wijzen zijn, voor het schrijwen van de geschiedenis van een discipline is juist de kwestie van het al dan niet delen van een vocabulaire van groot belang. De organisatie van mijn historisch verhaal in dit hoofdstuk is mede daarom niet dezelfde geweest als in hoofdstuk III Terwijl ik de geschiedenis van de vestiging van de sociologie in de Verenigde Staten heb beschreven als het opbouwen van eén vocabulaire, was dat voor de bespreking van Weimarsociologie niet mogelijk. Scheler en $L$. von Wiese bij voorbeeld hanteren niet hetzelfde vocabulaire, maar toch is dit geen beletsel geweest voor de vorming van een collectieve idlentiteit. Die identiteit wortelt in dit geval in een verwante cultuurpolitieke orientatie en in de nauwe band met de praktijk van de volkshogescholen. Terwijl in de Verenigde Staten de sociologie via eén taal met meerdere praktijken verbonden raakt, is de Weimarsociologie via meerdere talen verbonden met een praktijk.

Net als veel van zijn Amerikaanse generatiegenoten had Small bewondering voor het Duitse systeem van universitair onderwijs en onderzoek. Hij heeft Duitsland meermalen bezocht en als student ondermeer bij Schmoller colleges gevolgd. Na twee hoofdstukken over dè ontwikkeling van de sociologie in de Verenigde Staten zijn we in de twee daarop volgende hoofdstukken als het ware met hem mee gereisd naar Duitsland. In de jaren twintig en dertig zijn het omgekeerd Duitse sociologen als Walther en L. von Wiese die naar Amerika reizen om zich op de hoogte te stellen van de sociologiebeoefening aldaar. In het volgende hoofdstuk treed ik in hun voetsporen, zij het niet, zoals $\mathrm{L}$. von Wiese deed, om alsnog kennis te maken met Small en andere grondleggers van het vak, maar om een antwoord te vinden op de vraag of het ook na 1905 , wanneer de Amerikaanse sociologiebeoefening een snelle groei doormakt en het vak in meerdere scholen en specialisaties uiteen lijkt te vallen, nog mogelijk is de geschiedenis van de Amerikaanse sociologie te ordenen rond de geschiedenis van eén vocabulaịre. 
1. De voordrachten die op dit congres gehouden zijn en de notulen van de gevoerde dicussies zijn afgedrukt in Verhandlungen des Ersten Deurschen Soziologentages (1911). (1984).

2. De samenstelling van de sociologenvereniging is gedetailleerd in kaart gebracht in Käsler

3. Gecit. in Marianne Weber (1926): 430.

4. Zie Verhandlungen des Dritten Deutschen Soziologentages (1923).

5. Wiese (1957): 76. Naar aanleiding van Webers optreden tijdens deze congressen schrijft hij elders: 'Er neigte zu einem schroffen Entweder - Oder, fallte vernichtende Urteile über seine Gegner, rang aber auch mit quảlender Selbstkritik gegen jeden Zwiespalt, der in ihn selbst aufstieg. Die Schroffheit, mit der er die Ausrottung der Werturteile aus der wissenschaftlichen Lehre forderte, war stark gegen die eigene Natur gerichtet'. In Konig/Winckelmann (1963): 30.

6. König (1967): 9, mijn curs. Deze visie zet König mader uiteen in: Zur Soziologie der zwanziger Jahre, in: Reinisch (1961). Jonas, een generatiegenoot van König, laat in de jaren zestig een uit vier banden bestaande Geschichte der Soziologie verschijnen, 'bis heute Standardwerk der Profession und Pflichtlektüre jedes Soziologiestudenten' (Weyer (1984): 21). Over de sociologiebeoefening in de Weimarrepubliek oordeelt Jonas aldus: 'Die kritische Distanz, die Max Weber in wissenschaftlicher Methodik und Trennung von Wissenschaft und Politik postuliert hatte, wird aufgegeben, und die praktische Synthesis bzw. die absolute, d.h. weltanschauliche Gewissheit werden zum Programm der wissenschaftlichen Erkenntnis' (Jonas (1969): 59). Voor de kritiek van Dahrendorf, zie b.v. Dahrendorf (1971). Een soortgelijke negatieve beoordeling van de 'Weimarsociologie' vinden we ook in Schelsky (1959).

7. Kenmerkend voor deze blindheid is de mening die Karl Mannheim en ziljn vrouw over Hitler uitspreken tegenover E.E. Eubank. Deze Amerikaanse socioloog reist in 1934 door Europa om alle toentertijd bekende sociologen te interviewen. Deze interviews bleven onuitgegeven, maar zijn in 1985 tot een boekuitgave bewerkt door D. Kasler. In het verslag van Eubanks bezoek bij Mannheim lezen we (in de vertaling van Käsler): "Teilweise um Konversation zu machen und teilweise weil ich es wissen wollte, fragte ich die beiden nach ihrer Meinung über Hitler. Zu meiner Uberraschung antworteten beide sofort: "Wir mogen ihn" (We like him). Ich war erschreckt darüber, dass eine solche Meinung von Mitgliedern der jüdischen Rasse, jener Rasse also, die jener verfolgte, kommen konnte, und noch dazu von solchen, die selber gezwungen gewesen waren das Land zu verlassen. Als ich fragte, warum, sagten sie: "Nicht seiner Politk wegen, natürlich nicht, die uns als sehr falsch vorkommt. Aber aufgrund der Tatsache, dass er ein ernsthafter, aufrichtiger Mann ist (earnest, sincere man), der nichts für sich selber sucht, sondern sich mit ganzem Herzen darum bemüht, eine neue Regierung aufzubauen. Er ist tief aufrichtig, aus einem Stück (im Bericht von EEE auf Deutsch: Einez Stuck), und wir bewundern seine Rechtsschaffenheit und seine Hingabe".' In: Käsler (1985): 49 50. Vgl. Papcke (1986a).

8. Zie voor de ontwikkeling van de sociologie in Duitsland na de tweede wereldoorlog Weyer (1984).

9. Zie Dubiel (1978); Koenis (1990); Wiggershaus (1986).

10. Schad (1972); zie voor deze invalshoek ook Gorges (1986b).

11. Met als doel een winst- en verliesrekening van toenmalige theoretische ontwikkelingen op te maken, richt Habermas zich in zijn artikel 'Sociologie in de Weimarrepubliek' op de institutionele en thematische differentiatie van de sociologiebeoefening in de republiek van Weimar. Zie Habermas (1990). Dit hoofdstuk kent een andere opzet: het is niet mijn bedoeling de verschillende gestalten die de sociologiebeoefening toen aannam vanuit een hedendaagse opvatting over de identiteit van het vak te evalueren.

12. Zie voor de geschiedenis van dit instituut Alemann (1978). 
13. Simmels program, zo betoogt A.M. Bevers, "heeft voor veel misverstanden gezorgd. Maar het ging pas goed mis met deze formele sociologie (...) toen vertegenwoordigers van de zogenaamde formele school, met $\mathrm{L}$. von Wiese aan het hoofd, (de) tekortkomingen van Simmel probeerden op te heffen' (Bevers (1982). 18). Een soortgelijk oordeel vinden we o.a. bij Shils: 'Zum Ungluck für die deutsche Soziologie (...) waren Von Wieses Ideen nicht entwicklungsfahig. Er befasste sich primär mit Nomenklatur und Klassifizierung und stellte seinen Studenten keine andere Aufgaben' (Shils (1975): 78). Shils baseert zich waarschijnlijk op Aron die al voor de tweede wereldoorlog hetzelfde oordeel velt. Zie Aron (1935).

14. Bevers, op. cit: 18.

15. L. von Wiese beargumenteert deze objectkeuze als volgt: 'Die Soziologie hat (...) das soziale oder zwischenmenschliche Geschehen zum Gegenstande. In diesem einfachen, zahllose Probleme umschliessenden Satze, sind vor allem drei Thesen enthalten: 1. Es gibt eine soziale Sphäre des menschlichen Lebens; es besteht neben den Körpern und Seelen von Einzelmenschen ein unsubstanzielles Netz von Beziehungen zwischen ihnen, aus denen alle Kultur hervorgeht -2 Diese Sphäre ist bisher noch nicht genügend isoliert von den anderen Lebensbereichen studiert worden. - 3. Erst wenn man aus systematischen Beobachtungen des Menschenlebens erkannt hat, welcher Art die von der sozialen Sphäre ausgehenden Bewirkungen, ihre Möglichkeiten und ihre Grenzen sind, kann man von soziologischen Betrachtungsweisen in anderen Wissenschaften einen fruchtbaren Gebrauch machen'. In: Wiese (1926): 15.

16. Simmell (1908): 12 .

17. Wiese (1924b): 37.

18. Deze begrippen hanteert Simmel ook wel, maar hij neemt niet aan dat de geschiedenis van de menselijke interacties tot die twee basismechanismen te reduceren zijn.

19. Alemann, op cit.: 658.

20. Scheuch et.al. (1975): 281.

21. Scheler (1921): 30/31. Dit opstel is onder de titel Über die positivistische Geschichtsphilosophie des Wissens' herdrukt in Scheler (1963). Uit deze laatste uitgave is hier geciteerd.

22. Scheler (1928), herdrukt in Scheler (1963): 15-190.

23. Gecit. in Kasier (1984): 306. Matthes geeft aan dat toenmalige verschillen van mening over de identiteit van de sociologie langs twee dimensies te reconstrueren zijn. Ten eerste dacht men verschillend over de aard van het vak Naast de opvatting van Von Wiese dat de sociologie een specialisme is binnen de menswetenschappen met een eigen object, stonden twee andere opvattingen. Denkend in de lijn van Weber verstaan b.v. Sombart en Troeltsch onder 'sociologie' nog altijd een methodische instelling die men hanteert bij de studie van economische, juridische of theologische ontwikkelingen. "Für uns ist Soziologie mehr Voraussetzung, Sehweise und Hilfsmittel unserer Spezialstudien als ein für sich betriebenes Fach", zoals Troeltsch opmerkt. Auteurs als Oppenheimer en Spann begrijpen de sociologie tenslotte als een algemene, synthetiserende wetenschap. 'Sociologie' richt zich in hun ogen op de gehele menselijke ontwikkelingsgeschiedenis - een opvatting die verwant is aan die van Spencer en Small. Naast dit verschil van mening over de aard van het vak bestaan er verschillende visies op de universitaire plaats van het vak: hoort de sociologie thuis in de filosofische faculteit, of moet ze eerder een plaats hebben in de juridische en economische faculteit? De tegenstellingen lopen op dit punt niet parallel aan de eerdergenoemde. Von Wiese, maar ook Sombart en Oppenheimer opteren voor het tweede alternatief, terwijl zowel Freyer als Mannheim de sociologie in de filosofische faculteit willen onderbrengen. Vgl. Matthes (1973). Zie voor een andere classificatie van deze discussies Prahl (1986).

24. Zie voor nadere details Kåsler (1984): bijlagen $10 \mathrm{t} / \mathrm{m} \mathrm{15}$; Fornefeld et.al. (1984).

25. In: Protokoll der Tagung der Vereinigung der sozial- und wirtschaftswissenschaftlichen Hochschullehrer in Bad Kissingen am 24.9.1929. Afgedrukt in Matthes (1973): 236.

26. Vgl. Schad (1972): 6 en Käsler (1984): 161-162. Instemmend schrijft Käsler bij voorbeeld: 'Schad weist nach, dass die (...) Fächer der Psychologie, Pädagogik, Medizin und Psychiatrie, zusammen mit der Statistik, der Nationalökonomie und dem Strafrecht "had started to 
investigate systematically those problems areas which could have become the subject-matter of sociology" (Schad 1972: 8), lange bevor sich eine akademisch anerkannte Soziologie herausgebildet hatte; so blieb den deutschen Soziologen, wenn sie sich nicht an diesen Gebieten beteiligen wollten, gar kein anderer Weg, als sich einem mehr theoretischen Zugang zu allgemeinen, eher sozialphilosophisehen Fragen zuzuwenden'.

27. Dit aspect wordt benadrukt door Matthes (1973): 35-41.

28. Dit is de strekking van Lenk (1964): 257-287. Zie ook de paragrafen over de vroege Duitse sociologie in Van Houten (1973), Lukacs (1954), Ringer (1969).

29. "Im April 1919 zum Staatssekretär (...) ernannt, war Becker bis Januar 1930 ohne Unterbrechung als Staatssekretär oder Minister in der preussischen und deutschen Kulturpolitik tätig' (Wende (1959): 331). Ook als staatssecretaris gaf Becker in feite vorm aan het beleid. Vgl. Düwell (1971).

30. Becker (1961): 13.

31. Idem: 14.

32. Düwell, op. cit: 48. Over Schelers denkbeelden op het gebied van de culturi- en onderwijspolitiek, zie Schelsky (1961): 234-242; Staude (1967): hst. 4.

33. Döring (1975).

34. Vgl. Veraguth (1976): 50 e.v..

35. Deze gegevens zijn ontleend aan Emmerich (1958).

36. Gecit. in Kappe (1964): 75.

37. De Duitse volkshogeschoolbeweging is een rijkgeschakeerde beweging met vele vertakkingen en organisatievormen. Men richt volksbibliotheken op, organiseert toneelvoorstellingen voor het volk, entameert amateurtoneel en muziekbeoefening. Al deze activiteiten zijn erop gericht de werkende klasse in contact te brengen met de echte, hogere cultuur en hun zo voor het 'materialisme' immuun te maken. Kenmerkend voor de beweging is dat men experimenteert met nieuwe didactische vormen. Zo worden er op de volkshogescholen niet alleen allerlei voordrachten gehouden op het gebied van de politiek, de geschiedenis en de cultuur, men introduceert er ook het zogenoemde 'Rundgespräch'. Samen met de docent worden 'Arbeitsgemeinschaften' gevormd waarin intensief wordt gediscussieerd, met name over vraagstukken van zingeving en 'Weltanschauung'. Via deze gespreksgroepen zou men het belang van 'Weltanschauungen' maar tegelijk ook het eenzijdige karakter van extreme standpunten moeten leren inzien. Zie Emmerich (1958); Kappe (1964); Veraguth (1976); Wiese (1921).

38. Al deze sociologen zijn op verschillende manieren en ook om verschillende redenen actief in dit veld. De directe aanleiding voor $\mathrm{L}$. von Wiese om in Keulen een volkshogeschool op te richten was de opkomst van het radencommunisme in 1918. Als lid van de (liberale) democratische partij meende hij dat het volk 'geestelijke leiding' nodig had. Wiese gaf in Keulen speciale cursussen voor aan volkshogescholen verbonden docenten. (Wiese (1957)). In Leipzig deed Freyer dat ook, maar bij hem stond 'Volksbildung' niet in het teken van het aankweken van een liberaal-burgerlijke houding. Freyer zoekt meer aansluiting bij de rechtsradicale jeugdbeweging en sprak na de nationaal-socialistische omwenteling in 1933 juichend: "Volksbildung" kan zich eindelijk geheel richten op de vorming van eén volk. (Freyer (1934)). Over Freyer en zijn leerlingen zie Üner (1981). Over de betrekkingen van Vierkandt met de volkshogeschool in Berlijn zie Eisermann (1968). Over Oppenheimers activiteiten zie Schivelbusch (1982); Haselbach (1984). Over de cursussen van Plenge bericht Schäfers (1967). Vgl. ook Laqueur (1962).

39. Walther (1927). Voor Walthers intellectuele biografie zie Wassner (1984).

40. Wiese (1921).

41. Scheler (1924): vii. Deze bundel, waarin Schelers essay voor hel eerst verscheen, werd uitgegeven als de tweede band in de serie 'Schriften des Forschungsinstituts für Sozialwissenschaften in Koln'. Hierin verscheen ook een bijdrage van $L$. von Wiese: Wiese (1924a)

42. Scheler (1921): 35.

43. Wiese (1921): 552-568.

44. Wiese (1924b): 58. 
45. Ibid: ix.

46. Wiese (1921): 568 .

47. Niet alleen bij Scheler en $L$. von Wiese bestaat er een directe relatie tussen de aard van hun theorievorming en hun opvattingen over de volksopvoeding. Het type sociologie dat Freyer voorstond sloot nauw aan bij de manjer waarop hij de volksopvoeding vorm gaf. Volgens Freyer moet de sociologie de concrete maatschappelijke werkelijkheid bestuderen en niet zoals Simmel en Wiese doen, haar abstracte' vormen. Het meest werkelijke' was in zijn ogen de volksgemeenschap, Vgl. Freyer (1932). Mannheim was in Duitsland niet actief op het gebied van de volksopvoeding. Maar dat neemt niet weg dat er wel een relatie tussen zijn werk en die praktijk bestaat. In zijn kennissociologisch werk onderzoekt hij met name de mogelijkheid van een synthese van ideologieen en wereldbeschouwingen. Waar op veel volkshogescholen in de praktijk naar gestreefd werd, maakte Mannheim tot onderwerp van reflectie. Vgl. Lenk (1963); Kettler/Meja/Stehr (1984).

48. Zie b.v. Wiese (1934). In dit artikel tekent Von Wiese bezwaren aan tegen de poging van Charles A Ellwood om (in het voetspoor van Small) uit de sociologie een ethiek af te leiden. Elders merkt hij op: "Seit Kant ist es eine Errungenschaft der Wissenschaftslehre, dass die Forschung die Bereiche des Seins und des Sollens sondern muss und nicht miteinander vermengen darf. Dit betekent volgens Wiese niet dat de socioloog de ethiek de rug dient toe te keren: 'Die empirische Lehre von den Tatsachen des zwischenmenschlichen Lebens kann sich nicht (...) den Inhalt ihrer Aussagen von der Ethik vorschreiben lassen. Andererseits kann die Ethik ihr Bestes, den Gesinnungsidealismus, nicht zugunsten einer relativierten Forschung aufgeben. Die Soziologie aber sollte sich den Tiefblick der Ethik, ihren Willen zur Vervollkommnung aneignen, um nicht in einer blossen Mechanik von Bewegungsvorgängen stecken zu bleiben'. Wiese (1942): 34/54.

49. Vgl. Factor/Turner (1982); Fogt (1981).

50. Zie voor een bespreking van soortgelijke onbedoelde effecten van het waardevrijheidsprincipe na de tweede wereldoorlog Nauta (1971).

51. Vgl. Berking (1984), Lenk (1964), Pankoke (1977). 
EEN DISCIPLINE IN BEWEGING

\title{
Over de evolutie van een sociologisch vocabulaire
}

\author{
in de Verenigde Staten
}

\section{De dynamica van disciplines}

In het eerste hoofdstuk is een belangrijk voordeel van finalistische disciplinegeschiedenis aan de orde gesteld: ze maakt het mogelijk uitspraken te doen over de cognitieve ontwikkeling van een gehele discipline. Wanneer we het karakter van een discipline bepalen door haar te definiëren in termen van een gegeven object van onderzoek of een gegeven aantal problemen, dan laat de geschiedenis van die discipline zich moeiteloos beschrijven als een voortschrijdende studie van dat object of als een steeds betere behandeling van die problemen.

Inmiddels is duidelijk geworden hoe de vestiging van een discipline op een nietfinalistische manier beschreven kan worden. Maar laat de dynamica van een discipline zich ook op een niet-finalistische manier reconstrueren? Het vorige hoofdstuk geeft op die vraag onvoldoende uitsluitsel, omdat de sociologiebeoefening in de Weimarrepubliek zich niet liet beschrijven in termen van een veranderend vocabulaire. is het misschien toch zo dat het schrijven van disciplinegeschiedenis alleen mogelijk is wanneer we finalistische uitgangspunten hanteren?

Nee, zeggen wetenschapsfilosofen als Stephen Toulmin en David Hull, twee grondleggers van wat tegenwoordig 'evolutionaire kennistheorie' wordt genoemd. Vertegenwoordigers van deze wetenschapsfilosofische stroming benadrukken de verwantschap die in hun ogen bestaat tussen de groei van wetenschappelijke kennils en het darwinistischevolutionaire proces van biologische variatie en selectie. De historische ontwikkeling van disciplines laat zich net als de evolutie van populaties op een niet-finalistische manier beschrijven en verklaren.

Evolutionaire kennistheoretici verschillen van mening over de vraag waaruit de parallellie tussen kennisgroei en biologische evolutie precies bestaat, maar over eén ding zijn zij het eens: de geschiedenis van een discipline laat zich alleen in evolutionaire termen reconstrueren wanneer we te maken hebben met een 'echte' discipline. Wat is een echte discipline? In Human Understanding geeft Toulmin deze omschrijving: 'A collective human enterprise takes the form of a rationally developing "discipline", in those cases where men's shared commitment to a sufficiently agreed set of ideals leads to the development of an isolable and self-defining repertory of procedures; and where those procedures are open to further modification, so as to deal with problems arising from the incomplete fulfilment of those disciplinary ideals." 
Toulmins definitie heeft een belangrijke implicatie. De meeste menswetenschappen heten op grond van bovenstaand citaat geen 'echte" disciplines, omdat binnen die vakken geen consensus bestaat over de doelen, idealen en procedures van wetenschapsbeoefening. Het zijn, in de terminologie van Kuhn, pre-paradigmatische wetenschappen; vakken die, zoals Toulmin zegt, verdeeld zijn in partijen, facties of secten en waarvan de beoefenaren er niet in zijn geslaagd to hammer out a common set of disciplinary goals. ${ }^{2}$ Menswetenschappen als de psychologie en de sociologie noemt Toulmin daarom would be disciplines'.

Weliswaar is het mogelijk niet-finalistische disciplinegeschiedenis te beoefenen, maar voor de sociologie (en andere 'onechte' disciplines) dient een uitzondering te worden gemaakt, zo luidt het uiteindelijke antwoord van Toulmin en zijn wetenschapsfilosofische geestverwanten. Wie de dynamica van de sociologie in beeld wil brengen, dient zich te richten op scholen, stromingen en richtingen binnen dat vak, niet op de 'discipline' als geheel.

Tot een soortgelijke conclusie komen ook de meeste hedendaagse wetenschapshistorici en wetenschapssociologen, zij het op andere gronden. Doorgaans distantieren zij zich van het schematische onderscheid dat Toulmin en Kuhn aanbrengen tussen natuurwetenschap en menswetenschap. Door de menswetenschappen te typeren als preparadigmatisch' of als would be disciplines' beoordeelt men deze wetenschappen te veel vanuit een naturwetenschappelijk perspectief en komt het eigen karakter van deze wetenschappen onvoldoende uit de verf. Uit het werk van Kuhn halen zij dan ook niet het onderscheid tussen pre-paradigmatische en paradigmatische wetenschappen naar yoren; zif nemen veeleer een andere 'kuhniaanse' term tot leidraad voor hun onderzoek naar wetenschapsontwikkeling, namelijk het sociologische begrip wetenschappelijke gemeenschap'. Daarmee worden betrekkelijk kleine groepen van onderzoekers aangeduid, die voortbouwen op elkaars werk en die hechte netwerken vormen. ${ }^{3}$

Aan de introductie van dï begrip is een methodologisch advies verbonden: wie de sociale en cognitieve dynamiek van wetenschap wil begrijpen, dient zich te concentreren op het ontstaan, het veranderen en verdwijnen van deze betrekkelijk kleine gemeenschappen. Disciplines, zowel binnen de menswetenschappen als binnen de natuurwetenschappen, voldoen meestal niet aan deze voorwaarde. Alleen wanneer een nieuwe discipline of subdiscipline pas is ontstaan, vormen haar leden vaak ook een hecht intellectueel netwerk. Maar zodra een discipline zich verder ontwikkelt, ontstaan binnen haar grenzen doorgaans meerdere 'wetenschappelijke gemeenschappen'. Voor degene die geïnteresseerd is in de ontwikkeling van kennis verliest het disciplinebegrip in dat geval aan betekenis. $\mathrm{Na}$ hun ontstaan mogen disciplines het kader voor de inrichting van het universitaire onderwijs blijven vormen, voor de ontwikkeling van het onderzoek vervullen zij die functie niet meer, zo luidt de communis opinio onder historisch-sociologisch georiënteerde wetenschapsonderzoekers."

Finalistische disciplinegeschiedenis doet de problemen van identiteit, continuïteit, legitimiteit en autoriteit naar de achtergrond verdwijnen, zo is eerder betoogd. Geschiedschrijving die uitsluitend is gericht op de gang van zaken binnen wetenschappelijke gemeenschappen, biedt echter onvoldoende aanknopingspunten voor een meer adequate behandeling van die problemen; met name wanneer de lokale contexten waarin weten- 
schappelijk onderzoek wordt verricht, niet alleen het vertrekpunt, maar tevens het eindpunt van historisch onderzoek vormen. Op veranderingen in de identiteit van de discipline als geheel krijgt men dan geen zicht, terwijl ook de continuilteit die met het verleden wordt aangebracht, in dat geval moeilijk te traceren is. Door zich alleen op onderdelen van een discipline te concentreren, verliest men bovendien de vraagstukken van wetenschappelijke legitimiteit en culturele autoriteit uit het oog of bepaalde handelingen tellen als wetenschappelijke activiteiten en in hoeverre bepaalde studies zinvolle bijdragen aan de wetenschap mogen heten, zijn kwesties die binnen de moderne wetenschapsorde tot het domein van de discipline zijn gaan behoren. Ook voor het extern functioneren van wetenschap zijn disciplines in de 20 eeuw een steeds belangrijkere rol gaan spelen. Wanneer wetenschapsbeoefenaren in relatie treden met maatschap. pelijke of culturele praktijken, dan doen ze dit als lid van een discipline, niet als lid van een school of wetenschappelijke gemeenschap. Het culturele gezag dat zij in die contexten bezitten is een functie van de status van hun discipline.

De studie van wetenschapsontwikkeling op het niveau van disciplines blijft daarom zinvol. Tegelijkertijd moet echter worden erkend dat in een niet-finalistisch betoog uitspraken over de dynamica van een gehele disscipline terecht worden geschuwd. Disciplines nemen op de wereld niet overal dezelfde vorm aan. Zeker voor de sociologie geldt dat we niet van landsgrenzen en nationale tradities kunnen abstraheren. Maar betekent dit dat we ook op deze meer lokale schaal de discipline als eenheid voor historisch onderzoek bij voorbaat moeten schrappen?

Tegen de achtergrond van deze wetenschapstheoretische overwegingen stel ik me in dit hoofdstuk de volgende opgave. Ongeveer vanaf het moment waarop we in hoofdstuk III Small en zijn collega's verlieten, komt de Amerikaanse sociologie in een stroom. versnelling terecht. Het vocabulaire wordt in verschillende richtingen vernieuwd en binnen de grenzen van de discipline ontstaan ook meerdere wetenschappelijke gemeenschappen. Is het desondanks mogelijk om een verhaal te schrijven over de ontwikkeling van de discipline in de Verenigde Staten als geheel terwijl daarin de sociale en cog: nitieve dynamiek van de toenmalige sociologiebeoefening toch niet-finalistisch wordt geinterpreteerd?

\section{Twee redes, vier typen krachten}

'De sociologie heeft de toekomst!' Ferdinand Tonnies' weigering om in 1910 de eerste bijeenkomst van de Duitse sociologische vereniging met deze woorden te openen, staat in schril contrast met de manier waarop Albion $W$. Small vijf jaar eerder de eerste bijeenkomst van de American Sociological Society toespreekt. ${ }^{5}$ De toekomst van de sociologie kunnen we met groot vertrouwen tegemoet zien, houdt Small het 115 leden tellende genootschap in zijn openingsrede voor ${ }^{6} \mathrm{De}$ wetenschapsgeschiedenis leert ons immers, zo betoogt hij, dat wanneer een groep wetenschapsmensen op hoofdpunten eenmaal overcenstemming heeft bereikt, zij weinig moeilijkheden meer te duchten heeit. ${ }^{7}$ En in die fase bevindt zich inmiddels de sociologie in de Verenigde Staten, want over de meeste kwesties zijn wij het zo goed als eens.

Toch is de eenstemmigheid nog niet volmaakt, moet Small in 1905 toegeven. Met name over de aard van de krachten die mensen samenbinden, wordt verschillend gedacht. Zijn ze van hetzelfde type als de krachten die de flora en fauna hebben 
voortgebracht? Of zijn ze van een essentielel andere soort? Zijn het, kortom, fysische dan wel psychische krachten? Dit enig overgebleven conflict zal zich echter spoedig oplossen, voorspelt Small. Want we beseffen steeds meer dat het hier geen of-of kwestie betreft. In feite hebben we van doen met twee standpunten die elk een bepaald aspect van het menselijk samenleven belichten.

Dertig jaar later is het enige sociologische meningsverschil dat voor Small nog overbleef, niet opgelost, maar zo goed als vergeten. In 1935 spreken de meeste sociologen niet meer van fysische en psychische krachten; sociale krachten worden nu onderverdeeld naar persoonlijke en onpersoonlijke mechanismen. De rede waarmee $F$. Stuart Chapin (1888-1974) in 1935 de dertigste bijeenkomst van de Amerikaanse sociologievereniging opent, illustreert deze verandering. ${ }^{8}$

Wat is de taak van de sociologie?, vraagt Chapin zich af. Om tot een antwoord te komen, dienen we om te beginnen twee gebieden van sociaal handelen te onderscheiden. Tot het eerste gebied behoren zaken als leidinggeven, regeren en sociaal hervormingswerk. Daarbij gaat het steeds om vormen van doelgericht handelen waarbij mensen worden geleid door ideeen en motieven, maar ook door wensen en aandriften; of, zoals Small gezegd zou hebben: handelen kan zowel door psychische als fysische krachten worden gestuurd. Dit laatste onderscheid wordt door Chapin echter niet meer gemaakt: ideeẻn, motieven, wensen en aandriften rubriceert hij onder éen begrip: persoonlijke sociale krachten.

Het tweede gebied van sociaal handelen bestaat uit de onbedoelde gevolgen die voortvloeien uit de onderlinge verbanden tussen doelgerichte handelingen. Dit soort fenomenen noemt Chapin onpersoonlijke sociale krachten, omdat, zo zegt hij, de keten van oorzaak en effect zo lang en gecompliceerd kan zijn, dat de consequenties niet kunnen worden geinterpreteerd als de gerealiseerde plannen van bepaalde personen'.

De dichotomie van persoonlijke en onpersoonlijke krachten verbindt Chapin met een tweede onderscheid. Deze beide gebieden van sociaal handelen corresponderen met twee typen sociale theorie: normatieve en niet-normatieve. Normatieve theorieen bestrijken het gebied van de persoonlijke krachten, het gebied van de ideeên, meningen en emoties. Deze theorieèn kenmerken zich door hun niet-kwantitatieve inslag en hun aandacht voor principes die sociaal handelen zouden moeten leíden. Niet-normatieve theorieen daarentegen abstraheren van motieven, opinies en waardeoordelen; ze richten zich op het verklaren van onpersoonlijke sociale krachten en doen dat zo mogelijk in statistische termen.

In 1935 vormt de sociologische discipline geen wetenschappelijke gemeenschap in de zin van Kuhn meer. De American Sociological Society begon als een betrekkelijk klein genootschap, maar is nu uitgegroeid tot een vereniging van ruim duizend leden; tussen de lokale onderzoekstradities die zich inmiddels in Chicago, in New York en in enkele andere plaatsen hebben gevormd, bestaan diepgaande verschillen van mening over de doellen en methoden van sociologisch onderzoek. ${ }^{10}$ Toch presenteert Chapin de sociologie als een gecoördineerde opmars naar de waarheid, als een gezamenlijk project waarvan de deelnemers elkaar niet voor de voeten behoeven te lopen. Net als Small dertig jaar eerder veronderstelt Chapin zo het bestaan van een disciplinaire orde, $i c$. een kader waarbinnen kan worden vastgesteld wat als sociologiebeoefening telt en hoe verschillende benaderingen zich onderling tot elkaar verhouden. 
Opmerkelijk is ook een tweede overeenkomst tussen de beide redes. Weliswaar typeert Chapin het sociologische project anders dan Small, maar ze bedienen zich op een verwante manier van het begrip "sociale kracht". Beiden ordenen ze hun discipline immers via een classificatie van sociale krachten. Deze verwantschap is niet toevallig. Bij alle veranderingen in vocabulaire die zich tussen 1905 en 1935 voordoen, blijft de term 'sociale kracht' in de Amerikaanse sociologie een prominente rol vervullen - hoezeer de betekenis ervan ook variëren mag. Biedt deze omstandigheid niet een oplossing voor de problemen die in de opening van dit hoofdstuk zijn geschetst? Voor een niet-finallistische reconstructie van de ontwikkeling van de Amerikaanse sociologie als discipline lijken de lotgevallen van dit begrip in elk geval een geschikt aanknopingspunt te vormen.

Om aan de hand van verschuivingen in de betekenis van het begrip 'sociale kracht' een geschiedenis van de discipline te kunnen schrijven, moeten we echter eerst weten hoe het na 1905 is gegaan met het progessief-evolutionair vocabulaire waarvan de generatie van Small zich bediende bij de vestiging van de sociologie als academische discipline.

\section{Scheuren in het sociologische gelid}

In 1905 zijn de taken die Amerikaanse sociologen zich stellen, het vocabulaire dat ze hanteren en de praktijken waarop ze zich orienteren, nog nauw op elkaar afgestemd. Maar deze afstemming blijkt daarna al snel problemen op te roepen. Het wordt moeilijk de sociologie te presenteren als een academische discipline, terwijl men zich tegelijkertijd keert tegen het principe van intellectuele arbeidsdeling, zoals Small doet Die opstelling wordt na 1905 door zijn sociaalwetenschappelijke collega's in toenemende mate als innerlijk tegenstrijdig beoordeeld. Daarvoor zijn in essentie drie ontwikkelingen verantwoordelijk: de manier waarop de sociologie zich demarqueert, gaat steeds meer uit de pas lopen met de demarcatiestrategieẽn van andere menswetenschappen; de veronderstellingen waarop de sociologische theorievorming berust, worden gestaag verdrongen door nieuwe ideeen omtrent het karakter van wetenschap; de wijze waarop in de sociologie theorie en praktijk zich tot elkaar verhouden, sluit steeds slechter aan op de veranderende maatschappelijke rol van deze wetenschap. Deze trends verstoren de sociologische eenheid die Small in 1905 voor ogen stond. Ze geven aanleiding tot controversen en resulteren uiteindelijk in verschillende transformaties van het sociologisch vocabulaire. Om die transformaties te kunnen plaatsen is het nodig de drie genoemde ontwikkelingen nader te belichten.

\section{Generalisme of specialisme?}

Wanneer Small in 1907 in een programmatisch artikel nogmaals betoogt dat de sociologie een coordinerende taak heeft ten opzichte van de andere menswetenschappen, slaan enkele vertegenwoordigers van de aangesproken wetenschappen hard terug. De verschillende menswetenschappen kunnen gebruik maken van elkaars kennis, maar afhankelijk van elkaar zijn ze geenszins, zo repliceert bij voorbeeld de econoom Hoxie in 1907.'11 Iedere menswetenschap bestudeert de menselijke ervaring vanuit een eigen 
invalshoek. Wanneer Small diesalniettemin stelt dat zijn wetenschap een bijzondere positie inneemt, dan kunnen we die mening derhalve maar op twee manieren uitleggen, aldus Hoxie. Of Small huldigt het standpunt dat men de menselijke ervaring kan bestuderen vanuit meerdere perspectieven tegelijk; of Small meent dat én invalshoek superieur is aan alle andere.

Welnu, het eerste standpunt belichaamt een niet te realiseren ideaal, betoogt Hoxie. Want analyse en classificatie, de essentiële bestanddelen van elk onderzoek, zijn slechts mogelijk vanuit een bepaald gezichtspunt, niet vanuit vele gezichtspunten tegelijk. Veronderstel dat iemand geinteresseerd is in de ethische, esthetische en economische betekenis van menselijk handelen. Dan kan men dat handelen op elk van die drie aspecten onderzoeken. Maar zou, zo vraagt Hoxie retorisch, "this treefold analysis give you the elements of human experience from the combined standpoint of ethics, aesthetics, and economics?. ${ }^{12} \mathrm{Er}$ is geen enkele reden om daarop te hopen, want die verschillende perspectieven laten zich niet onder een gezamenlijke noemer brengen. Met de menselijke ervaring is het in dit opzicht net zo gesteld als met een mand appels: men kan ze classificeren naar kleur, omvang en zoetheid, maar omdat deze maatstaven onderling onafhankelijk zijn, bestaat er niet eén overkoepelend indelingsprincipe.

Blijft over de gedachte van een hiërarchie in invalshoeken. Zo'n hiërarchie veronderstelt echter dat de menswetenschappen op elkaar voortbouwen, maar dat is volgens Hoxie geenszins het geval. De politieke economie bij voorbeeld begint niet daar waar de psychologie eindigt; ze richt zich op geheel andere problemen. Wie toch volhardt in de gedachte dat psychologische of sociologische problemen belangrijker zijn dan economische vraagstukken, is als degene die meent dat de kleur van appels er meer toe doet dan hun omvang.

De wijze waarop Small voor de sociologie een bijzondere positie opeist, is ongefundeerd, concludeert Hoxie. Wanneer men zich van andere menswetenschappen wenst te onderscheiden, dan staat ook voor sociologen slechts eén mogelijkheid open: 'Sociology, if it signifies anything scientifically, must be simply a new independent social science based on a new principle of classification. We can leave to sociologists the statement of what that principle of classification really is. That is to say, we can let them fight the matter out among themselves: ${ }^{13}$

De controverse die aldus door Hexie wordt aangezwengeld, is het eerste duidelijke signaal voor het feit dat de sociologische pretentie niet meer op een vanzelfsprekende manier aansluit bij de positie die sociologen binnen de academische gemeenschap innemen. De opmars van de universiteit, ten koste van het traditionele college, heeft tot gevolg gehad dat institutionele zelfstandigheid (een eigen opleiding, een eigen beroepsvereniging) een noodzakelijke voorwaarde wordt voor het verwerven van wetenschappelijk legitimiteit. Maar in het verlengde van die verandering wijzigt zich ook de relatie tussen wetenschappen onderling: in een situatie waarin disciplines naar autonomie streven, verliezen traditionele pogingen om via een hiërarchie van classificatieprincipes een gezagsverhouding tussen wetenschappen aan te brengen hun zin.

In de Verenigde Staten geeft het filosofisch pragmatisme uitdrukking aan deze verandering. Een belangrijke reden voor de populariteit die deze filosofie na 1900 verwerft, is dat ze juist op de nieuwe academische structuur inhaakt: filosofen als James en Dewey nemen afstand van het idee van een vaste rangorde tussen wetenschappen. 
Het beeld van een hiërarchische zijnsorde die dit idee veronderstelt, wordt door een pluralistische zienswijze vervangen. De verschillende manieren waarop wij de wereld ordenen en vormgeven, staan naast elkaar, niet onder elkaar, betogen deze pragmatisten. 14

Voor wie zich op zo'n pluralistisch standpunt stelt, zoals Hoxie in feite doet, is de demarcatiestrategie die Small kiest, niet langer toegesneden op haar doel. Die strategie is immers gebaseerd op de gedachte dat de sociologie een synthese van alle sociaalwetenschappelijke 'deelkennis' dient te bewerkstelligen. Van zo'n uiteindelijke of absolute synthese kan echter geen sprake zijn, 'except on the basis of some extrascientific presupposition - some standard of values intuitively or authoratively established:.15 De keuze die de sociologie aldus opgedrongen wordt, is duidelijk: of men stelt de pretenties bij, of men plaatst zich buiten de wetenschappelijke discussie.

In zijn reactie zoekt Small inderdaad naar een mogelijkheid de sociologische pretenties beter af te stemmen op de zelfstandige positie die het vak inmiddels op enkele universiteiten verworven heeft. Sociologie, geeft Small tegenover Hoxie toe, staat als academische discipline inderdaad niet boven andere menswetenschappen. Maar, zo vervolgt hij, over sociologie in die zin sprak ik ook niet, al heb ik dat wellicht onvoldoende duidelijk gemaakt. De sociologie waar ik op doelde, is sociologie als een manier van kijken, als een methodologische instelling. En tussen beide betekenissen bestaat zeker geen noodzakelijk verband: 'It is a pure accident that sociology in this second sense is at present chiefly pursued by persons whose academic post falls within the academic department entitled "sociology":16 Om verdere verwarring te voorkomen neemt Small zich voor sociologie in die tweede (en voor hem eigenlijke) zin van het woord in het vervolg aan te duiden als 'de sociologische beweging".

Small presenteert dit nieuwe onderscheid louter als een verduidelijking van het standpunt dat hij altijd al innam. Maar is dat ook het geval? In het verleden had hij immers geen tweede term nodig: de sociologie als discipline en datgene wat hij nu 'de sociologische beweging" noemt, vielen bij hem samen, niet toevallig maar noodzakelijkerwijs. In zijn reactie op Hoxies kritiek houdt Small weliswaar vast aan de stelling dat sociologie een wetenschap is die de samenleving in haar geheel bestudeert, maar door te gaan spreken van een 'beweging' verdwijnt een duidelijke empirische referentie. Tot 'de sociologische beweging' kunnen zowel sociologen als niet-sociologen behoren; de academische positie die men inneemt, is zelfs geheel irrelevant, zoals Small expliciet opmerkt. Het enige wat telt is een juiste intellectuele instelling. Terwijl de sociologie als discipline inmiddels een professioneel aanzien begint te krijgen, keert Small terug naar een stellingname waar hij zich vroeger in de strijd met Sanborns Sociale Wetenschap juist tegen afzette: sociologie is net als de 19e-eeuwse Sociale Wetenschap geen apart vak, maar verwijst louter naar een bepaalde intellectuele houding of mentaliteit.

Deze uitweg is voor de nieuwe generatie professioneel geschoolde sociologen weinig aantrekkelijk. Maar Small had in zekere zin geen alternatief voorhanden. Want wie zoals hij onverkort vasthoudt aan het progressief-evolutionair vocabulaire, kan Hoxies advies (laten de sociologen een eigen classificatieprincipe naar voren brengen) eenvoudigweg niet opvolgen. Voor de gebruikers van dat idioom is de menselijke ervaring immers ondeelbaar. 
Diepe oorzaken of observeerbare effecten?

Bij hun zoeken naar de diepere oorzaken van maatschappelijke verschijnselen kwamen sociologen als Ward, Small en Giddings uit op een aantal in de evolutie gevormde krachten. Deze manier van redeneren wordt in de eerste decennia van de $20 \mathrm{e}$ eeuw echter steeds meer gezien als onwetenschappelijk.

Het progressief-evolutionair vocabulaire impliceert een theorie over oorzakelijkheid die verbonden is met de eerder besproken noties van samenhang en diepte. Er wordt verondersteld dat elk sociaal verschijnsel de manifestatie is van een of meerdere sociale krachten, die op hun beurt zijn opgebouwd uit meer elementaire fysische en psychische krachten. 'Verklaren' wordt in dit kader niet opgevat als het zoeken naar regelmatigheden in de sociale realiteit, maar verwijst naar het opsporen van fundamentele principes achter het menselijk handelen.

De theorie en praktijk van dit sociologisch verklaren verraadt een deterministisch wereldbeeld, dat na 1905 niet in haar geheel, maar wel op onderdelen onder druk komt te staan. Determinisme in de betekenis dat al het menselijk gedrag causaal kan worden verklaard, staat binnen de Amerikaanse menswetenschappen tijdens het interbellum niet wezenlijk ter discussie. Maar met determinisme kunnen we ook bedoelen dat alle wormen van menselijk gedrag uiteindelijk terug te voeren zijn op een betrekkelijk klein aantal fysisch-biologische en/of psychologische wetmatigheden. Small c.s. verdedigen deze sterke vorm van determinisme, die een reductionistische wetenschapsopvatting impliceert. Dat wil in dit geval zeggen: al datgene wat zich in de samenleving voordoet, heet pas werkelijk 'verklaard' te zijn, wanneer het te 'reduceren' is tot een effect van het totaal aan fysisch-biologische en psychische krachten.

Dit reductionisme vormt het wetenschapsfilosofische fundament voor Smalls plaatsbepaling van de sociologie boven de andere menswetenschappen. Maar de kritiek erop is inmiddlels toegenomen. Twee ontwikkelingen werken dat in de hand.

Op de eerste plaats beginnen, na de geschiedwetenschap, de economie en de psychologie, nu ook de culturele antropologie en de politieke wetenschap zich te profileren als zelfstandige disciplines. En dat gebeurt op een manier die haaks staat op de sociologische demarcatiestrategie.

Terwijl de generatie van Small voor de sociologie geen zelfstandig object opeist, doet de stamvader van de Amerikaanse antropologie, Franz Boas, dat wel. "Cultuur' is een zelfstandig onderzoeksgebied, leert hij zijn leerlingen Lowie en Kroeber. Rond 1910 openen zij een offensief tegen alle reductionistische definities van 'cultuur". Als eersten in de Amerikaanse mens wetenschappen trekken zij uit complexe theoretische discussies in de biologie de ondubbelzinnige conclusie dat ras en cultuur niets met elkaar hebben uit te staan. De lamarckiaanse gedachte dat karaktereigenschappen overerfbaar zijn, is niet alleen een biologische monstruositeit, verklaart Kroeber in 1915; ze is evenzeer op historische gronden onjuist, daarmee doelend op de gedachte dat de sociale evolutie een unilinair patroon zou kennen. Samenlevingen verschillen, maar ze afzetten op een hiërarchische schaal is onzinnig: de westerse mens staat niet op een evolutionair hoger niveau dan zijn soortgenoten elders op de wereld. ${ }^{17}$

Naast biologische factoren worden ook fysisch-geografische en psychologische factoren als verklaringsgronden uitgeschakeld. Het onderzoek van verschillende leerlingen van Boas heeft als strekking dat de geografische context een te verwaarlozen invloed heeft 
op de ontwikkeling van een cultuur. De psychologie houdt men op afstand door strikt te onderscheiden tussen het individu en de groep waartoe hij behoort. De antropoloog concentreert zich op groepsgedrag en kan daarom het individu negeren, redeneert Kroeber. De ethnograaf doet er kortom verstandig aan uit te gaan van het principe omnis cultura ex cultura, zoals zijn collega Lowie het in 1917 uitdrukt. ${ }^{18}$ Een cultureel feit dient te worden verklaard door een ander cultureel feit.

In de politieke wetenschappen zien we een soortgelijke ontwikkeling. De paradigmatische aanval op reductionistische manieren van redeneren staat hier op naam van Arthur F. Bentley. Deze publicist, later vooral bekend vanwege zijn samenwerking met Dewey, deed in 1908 een studie verschijnen die nogal wat opzien baarde: The Process of Government. In dit boek introduceert Bentley het begrip pressiegroep in de politieke wetenschap. Door consequent de gedachte uit te werken dat alle politieke verschijnselen het produkt zijn van groepen die druk op elkaar uitoefenen, vervangt Bentley en passant biologische metaforen door aan de mechanica ontleende beelden. De matschappij is geen organische eenheid, ze kent geen sociale geest en al evenmin én publieke opinie die, in toenemende mate, het algemeen belang belichaamt. Ook in een democratie strijden verschillende belangengroepen om de macht; en al is het waar dat daar geen wapengekletter meer aan te pas komt, met vooruitgang in redelijkheid, zegt Bentley, heeft dat weinig van doen. ${ }^{19}$

Alvorens Bentley echter tot een uiteenzetting van deze pressiegroeptheorie komt, neemt hij een lange aanloop. Onder het motto 'To prepare the way" rekent hij ondermeer af met de theorieen van Spencer, Ward, Small en Giddings. Bentley stelt zich op het standpunt dat sociale verschijnselen niet kunnen worden verklaard door te verwijzen naar de psychische kwaliteiten van de betrokken individuen. En dat is precies wat de genoemde drie sociologen hebben geprobeerd te doen, meent hij:

Neem Smalls theorie van de zes menselijke basisinteressen. We kunnen verschillende soorten van sociale activiteiten onderscheiden en dus moeten er verlangens of behoeften zijn die met elk type corresponderen, redeneert Small kennelijk. Om collectieve belangen te verklaren doet hij welbeschouwd een beroep op een soort 'soul-stuff. Maar kan langs deze weg ook maar éen concreet sociaal verschijnsel werkelijk worden verklaard? De rol van de 'railroad interest' in de Amerikaanse politiek, bij voorbeeld? Bentleys antwoord is duidelijk: 'It indicates the social fact, but not the individual soul's desire. It cannot actually be built up, piece after piece, out of those soul's desires; or, better said, to avoid being too absolute on the point, it has not been so built up either by Professor Small or by anyone else. They have hitched some of the desires to it, just as one might hitch a demon to a thunderstorm: ${ }^{20}$

Vanuit de politieke en antropologische wetenschap gezien, is de sociologische verklaringsstrategie onwetenschappelijk. Voor het verklaren van cullturele en politieke activiteiten schiet een typologie van sociale krachten tekort; ze leidt tot speculaties, niet tot observaties en werkelijke verklaringen.

Het idee van zo'n typologie werd tegelijkertijd langs een tweede weg ondermijnd. In hun theorieen over sociale krachten gaan auteurs als Ward, Ross en Small ervan uit dat we aandriften, verlangens en behoeften kunnen isoleren van hun werking; ze hebben een bestaan onafhankelijk van het menselijk handelen. Deze veronderstelling spoort inmiddels echter niet meer met nieuwe psychologische denkbeelden. 
Terwijl Small in Chicago streeft naar een verwetenschappelijking van de sociologie, werken aan dezelfde universiteit de psychologen Angell en Moore, tezamen met Dewey, aan een psychologie die niet gericht is op mentale inhouden, maar op mentale activiteiten. Aansluitend bij pragmatistische veronderstellingen stellen zij in plaats van het bewustzijn nu de interactie tussen individu en omgeving centraal. Het bewrustzijn wordt door hen opgevat als een functioneel onderdeel van het proces waarin een organisme zich instelt op zijn omgeving, dat wil zeggen: het treedt alleen op als ons handelingspatroon wordt verstoord. Datgene wat wij 'bewustzijn' noemen, zo redeneren deze psychologen, dienen we niet langer te beschouwen als een manifestatie van meer verborgen liggende krachten, zoals 'de geest', 'de ziel', 'de wil' of 'het intellect' - dat zijn allemaal metafysische entiteiten die men moet laten vallen wanneer men van de psychologie een experimentele wetenschap wil maken.

Dit psychologisch functionalisme blijft evolutionistisch georienteerd, maar bezit tegelijkertijd een kwaliteit die de sociologische conceptie van psychische krachten mist. Doordat men zich richt op mentale activiteiten wordt niet langer gezocht naar bewustzijnsinhouden die kunmen gelden als de diepere oorzaken van menselijk gedrag, maar verlegt de aandacht zich naar de directe aanleldingen en consequenties van verschillende soorten gedragingen. Aldus opent zich het perspectief van een experimentele en praktisch georienteerde wetenschap die de (Amerikaanse) psychologie ingrijpend zal veranderen. Van een nauw met de filosofie verbonden leer over het bewustzijn ontwikkelt ze zich tot een autonome discipline die het menselijk gedrag tot haar object maakt. $^{21}$

Het succes van de experimentele psychologie zorgt ervoor dat de daarin belichaamde manier van redeneren al snel model gaat staan voor menswetenschappelijk redeneren in het algemeen, een trend die nog eens door de gelijktijdige opkomst van de (wiskundige) statistiek wordt versterkt. Richt u niet op de herkomst, op de (diepere) oorzaken van verschijnselen, maar op de observeerbare condities en effecten van gedrag, luidt de boodschap van de neo-positivistische wetenschapsleer van de Engelse statisticus en psycholoog Karl Pearson; een boodschap die, wanneer ze na 1910 ook onder sociologen begint aan te slaan, de gehele demarcatiestrategie van Small c.s. pas goed op losse schroeven zet. Want achter al hun inspanningen om een typologie van sociale krachten te ontwikkelen, gaat immers een $19 \mathrm{e}$-eeuwse wetenschapsopvatting schuill die zij bijna allemaal rechtstreeks aan Spencer ontlenen. Wetenschappelijke kennis onderscheidt zich van niet-wetenschappelijke kennis, zo leerde hij hen, doordat het geordende kennis is. Het ontwikkelen van classificatieprincipes waarmee men 'de feiten' kan ordenen, werd door zowel Spencer als Ward, Small, Ross en Giddings als de kernactiviteit van wetenschapsbeoefening beschouwd; een gedachte waar Hoxie in zijn kritiek op Small ook nog aan vasthield. Maar volgens Pearson vergissen zij zich geheel. De kern van wetenschap, daar waar het in de wetenschap allemaal om draait, is de ontwikkeling van methoden van onderzoek, betoogt hij in zijn in Amerika veel gelezen boek The Grammar of Science. ${ }^{22}$ Niet classificatie, maar methodologie doet wetenschap van niet-wetenschap onderscheiden. 


\section{Opvoeding of onderzoek?}

Tijdens de jaarvergadering van de American Sociological Society in 1913 wordt onder voorzitterschap van George $\mathrm{E}$. Vincent een informele conferentie belegd rond het thema 'Is it possible for american sociologists to agree upon a constructive program?'23 Small beantwoordt de vraag bevestigend en hij stelt voor de volgende gedragslijn te beschouwen als bindend voor elke socioloog: Always do your part toward compelling everyone to treat human experience, from beginning to end (...) as a connected system of problems in morals: ${ }^{24}$ De reactie van jongere sociologen is koel. Het zoeken naar dit soort van overeenstemming is mogelijk noch wenselijk, is de overheersende teneur van hun bijdragen.

Te vaak en op een te ruime schaal wordt de socioloog nog gezien als "a programmaker rather than a scientist, a promotor rather than an investigator, merkt de aan de universiteit van Minnesota verbonden socioloog Samuel N. Reep op. Daarmee is niet gezegd dat de socioloog als "citizen" niet zou mogen streven naar sociale hervormingen. Maar, vervolgt hij, "for the sociologists to agree on any program of that kind and to attempt to give it prestige by calling it scientific would justly, in my opinion, relegate sociology to the scrap heap of social programs and postpone the day when it will be geneally conceded that a general science of society is possible.25 Small stelt de prioriteiten verkeerd, is Reeps boodschap. Zeker, de wetenschappelijke legitimiteit van het vak is gediend met het bereiken van interne overeenstemming, maar dan over een geheel andere kwestie dan Small meent. Waar wij sociologen het voor alles over eens zouden moeten worden, is 'that we must give primary attention to scientific methods'.

Ook Robert E. Park reageert. Na een journalistieke carriere en een studiereis naar Duitsland - waar hij promoveerde bij de neo-kantiaanse filosoof Windelband - is hij sinds kort werkzaam aan de universiteit van Chicago. In de jaren twintig zal hij uiltgroeien tot Chicago's meest prominente socioloog. ${ }^{26}$

Park beklemtoont eveneens het belang van onderzoek en de ontwikkeling van betere onderzoekstechnieken. Zoals de natuurwetenschap ons leert, is wetenschap uilteindelijk 'technique', zegt hij. Wetenschap zoekt alleen naar die relaties tussen oorzaak en gevolg die ons in staat stellen voorspellingen te doen. Sociollogie dient dit voorbeeld te volgen, want ook in dit geval vormt kennis van causale regelmatigheden de basis waarop 'all formal methods or organizations for the control or improvement of social life must rest'. Hij refereert in dit verband aan het fundamentele verschil dat Windelband heeft aangebracht tussen natuurwetenschappen en historische wetenschappen. Historische wetenschappen verschillen qua doel en methode van natuurwetenschappen doordat zij zich richten op concrete, aan tijd en plaats gebonden feiten. Uit dit onderscheid wordt in de Duitse neo-kantiaanse traditie de conclusie getrokken dat de sociologie tot de historische wetenschappen behoort, zoals Max Weber bij voorbeeld doet. Maar Park trekt de omgekeerde conclusie: sociologie wordt door hem gerangschikt onder de natuurwetenschappen!

Al zijn opmerkingen leiden tot een ander model van theorie en praktijk dan vroegere sociologen voor ogen stond, een wending waarvan Park zich terdege bewust is. 'It is true, of course, that the application of scientific methods to the investigation of social phenomena and the application of the results of these investigations to the control of social life have had a tendency to substitute machinery and technique in the place of 
sympathy and common-sense in our dealings with human beings. ${ }^{27}$ Park valt Small, de directeur van zijn eigen 'department', hier niet rechtstreeks aan. Maar zijn standpunt is duidelijk: in zijn maatschappelijke rol dient de socioloog niet verwant te zijn aan de dominee of de pedagoog, maar aan de ingenieur.

De verschillen van mening die tijdens deze 'informele conferentie' tussen oudere en jongere sociologen voor het eerst openlijk naar voren treden, kennen meer dan eén achtergrond. Naast de opkomst van nieuwe opvattingen over het karakter van wetenschap (die zojuist zijn besproken), zijn veranderingen in de praktijken waarop sociologen zich orienteren, een belangrijke aanleiding voor het ontstaan van dit generatieconflict. Sociologen zagen zich namelijk in toenemende mate geconfronteerd met wat we de professionalisering van hun praktijken kunnen noemen.

Terwij1 de eerste generatie Amerikaanse sociologen zich in hoofdzaak richtte op publieke opvoeding, ontwikkelt zich in de jaren tien en twintig in de Verenigde Staten een publiek domein dat door een nieuwe, professioneel geschoolde bureaucratie wordt bezet. Steden krijgen hun "citymanagers", civiele ingenieurs die leiding geven aan publieke werken als de aanleg van wegen, de verbetering van electriciteits- en watervoorzieningen. Deze nieuwe professie stijgt in aanzien naarmate duidelijk wordt dat hun technische kennis niet alleen de dienstverlening verbetert, maar bovendien bijdraagt aan aanzienlijke besparingen op de stedelijke uitgaven. De ingenieurs, die al snel naast uitvoerende functies ook beleidsfuncties toebedeeld krijgen, verdienen voor de stad hun eigen - hoge - salarissen gewoonlijk binnen een jaar terug, zo blijkt. De in de Amerikaanse politiek reeds lang bestaande weerstand tegen experts weten de 'citymanagers' als eersten te doorbreken. 28

Deze doorbraak draagt er mede toe bij dat na 1910 "efficientie" uitgroeit tot een belangrijk politiek concept. Efficiëntie is een kernbegrip uit de beweging van het wetenschappelijk management die rond dezelfde tijd van zich doet spreken. Maar het begrip slaat in bredere kringen aan: niet alleen op het gebied van de industriele produktie ontstaat een streven naar meer efficie̋ntie, ook op het gebied van het politieke bestuur zien we die tendens. Progressieve hervormers van rond de eeuwwisseling legden nog alle accent op morele deugdzaamheid. Geef ons minder corrupte politici en de verspilling van belastinggelden zal ophouden te bestaan, zo meenden zij. De roep naar meer 'efficièntie' brengt met zich mee dat niet alle aandacht meer uitgaat naar het morele gedrag van individuele politici. Bestuurstechnische vernieuwingen krijgen meer nadruk, ook al klinken de oudere morele connotaties daarin nog altijd door.

Zowel op stedelijk als op nationaal niveau gaat de roep naar meer 'efficiëntie' hand in hand met een versnelde groei van de administratieve bureaucratie. Die beweging beperkt zich niet tot het openbaar bestuur. $Z 0$ is in 1910 liefdadigheid al lang niet meer het gebied waarin uitsluitend jongedames uit hogere kringen hun levensbestemming vinden. Sociaal werk wordt een professie; er ontstaan opleidingsinstituten, zowel buiten als ook binnen de muren van de universiteit; men krijgt de beschikking over eigen tijdschriften en men richt tevens professionele verenigingen op. Maar misschien nog belangrijker is het ontstaan van allerlei 'foundations', zoals de Russell Sage Foundation. Deze charitatieve instellingen financieren alierlei projecten en stimuleren een verdere 'verwetenschappelijking' van het sociaal werk. Goede wil schiet in hun ogen meer en meer tekort, van belang wordt nu het kunnen beschikken over meer doeltreffende tech- 
nieken en meer efficiënte organisatievormen. Net als vanuit de burelen in Washington wordt vanuit deze hoek de roep naar 'feiten' luider en neemt de behoefte aan research toe. ${ }^{29}$

'Research' ontwikkelt zich na de eerste wereldoorlog ook onder sociologen tot een nieuw toverwoord in de strijd om cultureel gezag. Sociologen als Park duiden er het gericht zoeken naar onbekende feiten en verbanden mee aan, op gebieden die open staan voor sociale verandering. Research presenteren zij als een techniek, dat wil zeggen: het sociologisch onderzoek moet zo zijn ingericht dat de resultaten ervan aanknopingspunten bieden voor sociaal beleid, maar tegelijk dient de onderzoeker zich in het onderzoek zelf niet te orienteren op normatieve of politieke idealen. Met het begrip 'research' wordt zo een onderscheid tussen 'wetenschap' en 'politiek' geintroduceerd, dat op een wezenlijk punt afwijkt van Webers standpunt.

Wanneer Park spreekt over 'research' dan denkt hij aan de toepassing van 'de wetenschappelijke methode" op maatschappelijke problemen, een gedachte die hij wellicht heeft ontleend aan de pragmatistische filosofie van Dewey en Mead. Deze beide filosofen hadden een diepe bewondering voor de experimentele traditie binnen de moderne natururetenschappen. In woorden en daden heeft met name Dewey geprobeerd de experimentele, wetenschappelijke houding ingang te doen vinden in de sociale wetenschappen, de opvoedkunde, de ethiek en de politiek. Door een uitbreiding van het toepassingsgebied van 'de wetenschappelijke methode' zou ook op niet-natuurwetenschappelijke terreinen speculatie in te ruilen zijn voor daadwerkelijke vooruitgang, zou ook daar het geloof in eeuwige dogma's kunnen worden vervangen door het besef dat al onze kennis feilbaar is en derhalve voortdurend verbeterd en herzien moet worden. Vergeleken met de positie die Weber inneemt, spreekt vit deze opstelling een veel groter vertrouwen in wat wetenschap vermag. Webers restrictionisme is hen dan ook vreemd; ten aanzien van de maatschappelijke rol van de menswetenschappen nemen deze filosofen een expansionistisch standpunt in. Daarbij brengen zij wel een scheiding aan tussen politieke en ethische idealen enerzijds en wetenschappelijke feiten anderzijds, maar anders dan Weber beschouwen zij dit niet als een absoluut onderscheld: wetenschappelijk onderzoek kan in hun visie resulteren in een bijstelling van onze ethische en politieke idealen. Dit verschil vam inzicht hangt samen met de omstandigheid dat het onderscheid tussen normen en feiten bij pragmatisten (en ook bij sociologen als Park die zich metl hun denkbeelden verwant voelen) in een andere context staat als bij Weber. Weber behandelt het onderscheid vanuit een methodologische invalshoek, maar zijn standpunt stoelt uiteindelijk op filosofische argumenten, die hij voor een deel ontleent aan de kantiaanse traditie en voor een deel aan het werk van Nietzsche. Zo veronderstelt hij dat waarden niet bestaan, maar alleen gelden; en dat de wereld van de praktische waarden gekenmerkt wordt door een onverzoenlijke strijd. Dewey en Mead plaatsen het onderscheid tussen normen en feiten daarentegen in de context van het wetenschappelijk handelen. Wie zijn kennis wil verbeteren, zo leert de wetenschapsgeschiedenis, doet er verstandig aan om de wens niet de vader van de gedachte maken: normatieve preoccupaties belemmeren de wetenschappelijke vooruitgang. En voor het bewerkstelligen van maatschappelijke vooruitgang geldt hetzelfde, zo voegen zij daar aan toe. Door zo te redeneren krijgt 'het' waardevrijheidsprobleem bij hen een ander karakter. Het is noch primair een axiologisch noch primair een logisch probleem, maar 
een handelingsprobleem. Dat wil zeggen: het probleem draail rond de kwestie hoe een goed onderzoeker te werk moet gaan, hoe hij moet handelen om een optimaal resultaat te bereiken. Parks kritiek op de generatie van Small en zijn pleidooi voor 'research' staat in dit licht" het gaat hem er niet om politiek en ethisch handelen principieel te demarqueren van wetenschappelijk handelen; nee, ook hij redeneert 'pragmatisch': juist omdat sociologisch onderzoek volgens hem praktisch georienteerd dient te zijn, bestaat er een voortdurend gevaar voor wishfull thinking; om dall gevaar te beteugelen moeten sociologen een strikt onderscheid maken tussen probleemgericht onderzoek en toepassing'.

Door de sociologiebeoefening te identificeren met probleemgerichte 'research' wordt het belang van twee oudere vormen van empirisch onderzoek gerelativeerd: de 'social survey' en de sociaal-geografische studie. De zogenoemde 'surveys" waren veelal uitgebreide, aan de hand van beschrijvend-statistisch materiaal opgestelde rapporten over sociale misstanden. Dit type onderzoek, in de $19 \mathrm{e}$ eeuw de meest geavanceerde vorm van sociale wetenschap, wordt door Park en zijn generatiegenoten als onwetenschappelijk betiteld. Deze 'surveys', zo heet het nu, waren toch vooral een retorisch middell voor het in gang zetten van sociale veranderingen. Het verzamelen van feiten had bij dit type onderzoek de functie een sociaal-politieke positie meer gewicht te geven die voor de onderzoekers op voorhand evident was. ${ }^{30} \mathrm{Bij}$ de sociaal-geografische studies gold dit niet of althans in mindere mate. Maar door het ontbreken van elke probleemstelling kan ook dit soort onderzoek geen leidraad vormen voor sociale techniek. Het doel van deze door Small zo aangeprezen vorm van empirisch onderzoek was immers een regio of dorp in extenso te beschrijven.

Zowel het grotere belang dat aan 'efficientie' wordt gehecht, als ook de groeiende vraag naar op beleidsproblemen gericht onderzoek die daarmee samenhangt, dragen ertoe bij dat de argumenten waarmee de generatie van Small voor de sociologie cultureel gezag opeiste, hun kracht verliezen. Wanneer de sociologie haar praktische invloed behouden wil, dan zal ze zich moeten richten op de produktie van kennis die althans gedeeltelijk direct in sociaal beleid kan worden omgezet.

\section{Veranderingen in vocabulaire: differentiatie en continuïteit}

Na de eerste wereldoorlog ondergaat de sociologie in Amerika een aantal ingrijpende veranderingen. Pioniers als Small, Giddings en Ross bepalen niet langer de identiteit van het vak en de nieuwe generatie die nu aantreedt, neemt afstand van hun gewoonte sociologie te bedrijuen vanuit de leunstoel'. In de jaren twintig presenteert het vak zich niet langer als de synthese van alle andere menswetenschappen, maar als een empirische wetenschap met een eigen objectgebied.

De veranderingen die de discipline in de jaren twintig en dertig doormaakt, zijn vaak als een vorm van volwassenwording geduid: men leert te onderscheiden tussen cultuur en natuur; men leert te onderscheiden tussen empirie en theorie; men leert te onderscheiden tussen wetenschappelijke objectiviteit en maatschappelijk engagement. ${ }^{31}$ Maar de genoemde veranderingen laten zich ook op een meer zwartgallige manier interpreteren. Zij die de sociologie in Amerika vestigden onderschreven grotendeels de doeleinden van 
de Progressive Movement. Deze sterk ethisch gerichte hervormingsbeweging in de Amerikaanse politiek, sterft na de eerste wereldoorlog echter een zachte dood. Er volgt een periode van reactie en stagnatie: sociale wetgeving krijgt nauwelijks nog aandacht, de immigratie wordt beperkt, de drank verboden; anarchisten en andere links radicalen worden vervolgd, terwijl de Ku Klux Clan een populaire beweging wordt. De menswetenschappen, zo vervolgt deze lezing, vinden aansluiting bij deze omslag van politiek en cultureel klimaat door afstand te nemen van het sociale hervormingsdenken. Maar wat daarvoor in de plaats komt, heeft met wetenschappelijke vooruitgang weinig van doen. Vooral 'de manie van het meten' waar veel sociologen van in de ban raken, duidt op intellectuele steriliteit. In feite veranderen sociologen van bevlogen filosofen in kille bureaucraten. ${ }^{32}$

Interpretaties van het eerste, optimistische type hebben een duidelijk finalistische inslag: de opvatting dat de opvolgers van Small, Giddings en Ross de eerste echte stappen zetten in de richting van een meer volwassen vorm van sociologiebeoefening, is ontleent aan latere denkbeelden over wat sociologie zou moeten zijn. Maar de diskwalificatie van dit soort finalistische interpretaties betekent nog niet dat interpretaties van het tweede type de voorkeur verdienen. Wie meent dat een discipline als de sociologie slechts meedeint op de golven van de social-politieke cultuur negeert het vocabulaire waarvan de gemeenschap van sociologen zich bedient. Meningen kunnen snel veranderen, maar het idioom waarin men ze uitdrukt is minder wendbaar.

Vocabulaires transformeren zich, veranderen bij stukjes en beetjes. De geschiedenis van de Amerikaanse sociologie vormt daarop geen uitzondering. In de periode tussen 1905 en 1935 verdwijnt het progressief-evolutionair vocabulaire niet zonder meer, maar ontstaan er verschillende varianten of 'mutaties'. In elke variant worden sommige elementen uit het oude vocabulaire doorgestreept en andere toegevoegd. Daarbij zijn de delen die met het oude vocabulaire blijven samenvallen, niet in iedere variant dezelfde. Dit type verandering zal ik aan de hand van enkele voorbeelden illustreren. Zoals in het begin van dit hoofdstuk is aangekondigd, kies ik daarbij het begrip 'sociale kracht' als aanknopingspunt. De meningsverschillen die na 1905 over de aard van deze krachten ontstaan, kunnen een goed inzicht bieden in de verschillende transformaties die het sociologisch vocabulaire gedurende het interbellum ondergaat.

Deze transformaties bespreek ik in twee stappen. Allereerst worden in deze paragraaf drie exemplarische varianten op het progressief-evolutionair vocabulaire geintroduceerd, zoals die naar voren zijn gebracht door Charles Ellwood, Isaac Thomas en F. Stuart Chapin. Deze auteurs zijn niet willekeurig gekozen; zij vormen belangrijke representanten van de drie hoofdstromingen binnen de Amerikaanse sociologie tijdens het interbellum. In de volgende paragraaf wordt geprobeerd elk van deze variantlen te verbinden met de, zoëven besproken, kritiek op het progressief-evolutionair vocabulaire. ${ }^{33}$ Iedere variant kan begrepen worden, zo hoop ik in deze tweede stap van mijn argument aan te tonen, als een poging een antwoord te vinden op een of meerdere onderdelen van die kritiek.

\section{De sociale krachten van Charles Ellwood}

Tot de weinige publikaties van Amerikaanse sociologen die voor de tweede wereldoorlog in het Nederlands zijn vertaald, behoort een 'inleiding in de theorie van de sociologie' 
van Charles A Ellwood (1873-1946), een leerling van Small die zich in 1924 een jaar lang president van de American Sociological Society mocht noemen. Dit in 1935 verschenen boek komt vier jaar later in Nederland uit onder de titel De psychologie van de menselijke samenleving. Ellwood duidt sociale krachten hierin aan als bestanddelen, die noodzakelijk zijn, om ledere sociale situatie te verklaren'. Deze bestanddelen, zo vervolgt hij, moeten we verdelen in oorspronkelijke en afgeleide krachten. Tot de oorspronkelijke krachten rekent Ellwood:

1. De physische factoren,

(a) de geografische omgeving: klimaat, voedsel, natuurlijke bronnen, topografie enz.

(b) Biologische factoren: erfelijkheid, variatie, selectie, enz.

2. De psychische factoren,

(a) Impulsen, zowel de erfelijke (instinctieve) en de verworvene (gewoonten).

(b) gevoelens, erfelijke (emoties) en de verworvene (gewoonten).

(c) Intellectuele bestanddelen, waaronder de sensaties, percepties, concepties, verbeelding, rede enz.

Afgeleide sociale krachten zijn uit de oorspronkelijke psychische factoren samengesteld. Tot deze categorie rekent Ellwood:

- verlangens, wensen en sentimenten (hooldzakelijk opgebouwd uit impulsen en gevoelens);

- belangen en waarden (opgebouwd uit impulsen, gevoelens en intellectuele bestanddelen)..$^{3}$

Deze typologie is veel psychologischer van inslag dan de in hoofdstuk III aangehaalde typologie van Ward. Toch verschilt het schema qua opzet weinig van de manier waarop Ward bijna een halve eeuw eerder de sociale krachten had ingedeeld. De ordening is hilrarchisch en weerspiegelt als zodanig verschillende stadia in de kosmische evolutie. Die evolutie, schrijft Ellwood, kunnen wij ons het best voorstellen als een grote cirkel die "de andere vormen van ontwikkeling in zich heeft". ${ }^{35}$ In een figuur:

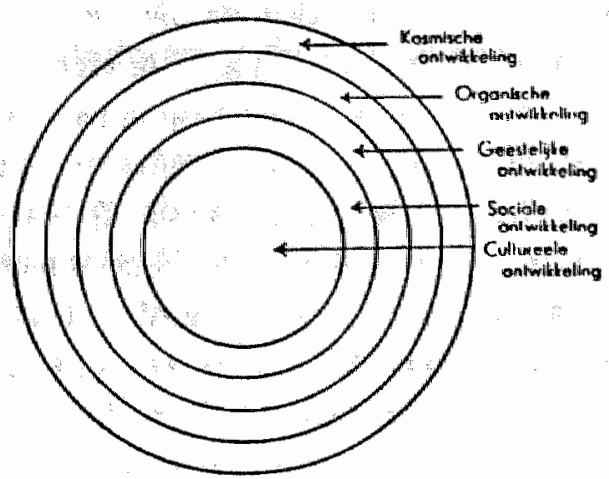

Ellwood is de representant van een stroming binnen de Amerikaanse sociologie die tijdens het interbellum onverkort vasthoudt aan het progressief-evolutionair vocabulaire. Naast het idee van een liniair proces van vooruitgang, vinden we bij Ellwood karakteristieke kenmerken van dit vocabulaire dan ook gemakkelijk terug. $1 \mathrm{k}$ beperk me tot twee illustraties. 
Binnen het progressief-evolutionair vocabulaire zijn, om te beginnen, maatschappelijke verschijnselen altijd een functie van fysische en psychische krachten. Ellwood blijft deze gedachte onderschrijven. Hij onderscheidt wel een sociale en culturele vorm van 'algemene ontwikkeling', maar deze zijn van een andere orde dan de drie eerste stadia: 'Het sociale is geen gebied op zich zelf, maar opgebouwd uit het biologische en psychologische' ${ }^{36}$ In termen van het model van de concentrische cirkels impliceert dit dat de 'sociale ontwikkeling' een resultante is van de organische - en de geestelijke ontwikkeling. Ook de culturele evolutie is geen 'aparte trap', maar op haar beurt 'een manifestatie van de geestelijke en sociale ontwikkeling onder menschelijke omstandigheden', ${ }^{37}$ Aldus heeft Ellwood, net als zijn voorgangers, aan twee basistypen van sociale krachten voldoende om de gehele menselijke evolutie te verklaren.

Ten tweede betekent 'samenleven' binnen het vocabulaire van Small c.s. zich associèren, zich verbinden met gelijkgestemden. Daardoor zijn twee motieven hier nauw met elkaar verweven: de gedachte dat het leven in groepen op zichzelf nog geen 'sociaal' leven is (samenleven veronderstelt bewustzijn, i.c. een ontwikkeling van 'geest') en de gedachte dat samenleven zich primair kenmerkt door eenheid, harmonie en gemeenschappelijke doeleinden. Ook deze koppeling vinden we bij Ellwood terug.

Zo mogen we van hem plantenkolonies geen 'maatschappijen' noemen omdat in zulke vormen van collectief leven "geen bewuste verhoudingen of "kameraadschap" bestaan. ${ }^{38}$ Even verderop meldt hij de lezer dat sommige sociologen de sociale ontwikkeling louter als een vorm van organische evolutie hebben beschouwd en levert daarbij dan het volgende commentaar: 'Deze opvatting schijnt steun te vinden in het feit, dat het tezamen leven in groepen op zeer lagen trap van de organische evolutie begint. Maar alleen met dien vorm van groepsleven zullen wij ons bezighouden, die door "kameraadschap" gekenmerkt wordt, of door sociale betrekkingen tusschen betrekkelijk onafhankelijke, bewuste individuen. Wij zijn overeengekomen alleen dat groepsleven, dat door wederkeerige geestelijke beinvloeding mogelijk is, als sociaal te beschouwen; ${ }^{39}$

Uit dit citaat blijkt tevens waarom in de bovenstaande figuur de cirkel van de 'geestelijke ontwikkeling' die van de 'sociale ontwikkeling' omvat: de evollutie van 'oorspronkelijke psychische factoren', die de geestelijke ontwikkeling mogelijk maken, gaat binnen deze stijl van redeneren vooraf aan de evolutie van 'afgeleide sociale krachten', die de sociale ontwikkeling in gang zetten.

Met deze illustraties van historische continuïteit is niet gezegd dat Ellwood zijn voorgangers louter napraat. Niet zonder reden figureert hij in de disciplinegeschiedenis van de Amerikaanse sociologie als een van degenen die het vak een eigen object hebben verschaft. Sociologie onderscheidt zich bij Ellwood namelijk niet langer meer van andere menswetenschappen door haar overkoepelende perspectief, haar synthetiserende manier van kijken. Kenmerkend voor de sociologie is haar gerichtheid op het leven in groepen. Dit impliceert dat in Ellwoods werk sociologie" voor cen groot deel gaat samenvallen met een vorm van beschouwende sociale psychologie, een wending die in zijn krachtentypologie ook tot uitdrukking komt. ${ }^{40}$

De introductie van een nieuw centraal begrip duidt niet altijd op een ingrijpende verandering in het vocabulaire dat men hanteert, zo leert het werk van Ellwood. Mede dankzij hem heeft het begrip 'groep' een prominente plaats gekregen in de Amerikaanse sociologische traditie, maar deze terminologische vernieuwing gaat in dit geval niet 
gepaard met een wezenlijke verandering in vocabulaire. Voor Ellwood is "groep" weinig meer dan een modern woord voor het traditionele begrip 'associatie".

\section{De sociale krachten wan Isaac Thomas}

In de geschiedenis van de Amerikaanse sociologie geldt 1918 als een belangrijk jaartal. In dat jaar namelijk publiceren de aan het instituut van Small verbonden socioloog W.I. Thomas (1863-1947) en zijn Poolse co-auteur Florian Znaniecki het eerste deel van The Polish Peasant in Europe and America, een boek dat beide auteurs voor de vergetelheid heeft behoed. Deze oorspronkelijk in vijf delen uitgegeven monografie - 2232 pagina's dik - wordt tegenwoordig algemeen tot de klassiekers uit de sociologiegeschiedenis gerekend. Coser spreekt van "the first great classic in American empirical sociology, ${ }^{\mathbf{4}}$ en Bulmer meent zelfs dat de geschiedenis van de Amerikaanse sociologie met de publikatie van dit werk pas serieus begint. ${ }^{42}$

The Polish Peasant is voornamelijk beroemd geworden doordat Thomas en Znaniecki er een nieuwe methode van onderzoek in introduceren. Aan de hand van persoonlijke documenten (brieven, autobiografieên) wordt een omvattend beeld gegeven van het immigrantenleven van Poolse katholieken in Amerika. De auteurs bespreken ondermeer hun herkomst, de problemen waarop zij in hun nieuwe omgeving stuiten, hun pogingen de eigen cultuur in Amerika in stand te houden en de conflicten met hun veramerikaniseerde' kinderen.

In de methodologische inleiding die aan het eigenlijke werk voorafgaat, vinden we een taxonomie van sociale krachten die Thomas in een latere studie, The Unadjusted Girl, nog verder uit zal werken. Thomas noemt deze krachten:

1. The desire for new experience.

2. The desire for security.

3. The desire for response:

4. The desire for recognition.

In tegenstelling tot alle eerder besproken classificaties is hier de volgorde onbelangrijk. De krachten van Thomas hebben zich namelijk niet in de loop van de sociale evolutie ontvouwd; ze zijn latent aanwezig in elk menselijk individu, op welk niveau van 'beschaving' hij zich ook bevindt. Tezamen definiẻren ze het begrip 'menselijke natuur'.

Thomas geeft zo de menselijke natuur een onveranderlijk karakter. In 1907 betoogde hij nog dat the characters of body and mind acquired by the parent are probably not inherited by the child ${ }^{\mathbf{4 3}}$, maar inmiddels is die waarschijnlijkheid voor hem een zeker feit geworden. Meer dan Small of Ellwood oriënteert Thomas zich op toen recente wetenschapsontwikkelingen, niet alleen in de biologie maar ook in de antropologie.

Maar juist doordat The Polish Peasant voor een groot deel aansluit bij de hierboven besproken antropologische inzichten uit de school van Boas, is het des te opmerkelijker dat Thomas toch een taxonomie van sociale krachten presenteert, ook al staan deze krachten niet meer in een evolutionaire hiërarchie. Latere sociologen beschouwen Thomas' getheoretiseer over vier 'universele verlangens' dan ook als een misser; als socioloog heb je zo'n taxonomie hellemaal niet nodig. Voor Thomas daarentegen heeft dit aspect van zijn werk wel degelijk een functie. Dat wordt duidelijk zodra we zijn 
sociologische theorie proberen te plaatsen in de context van het progressief-evolutionair vocabulaire.

Sociologen, waarschuwt Thomas, dienen niet de fout te begaan die literatoren, journalisten, reizigers en de schrijvers van populair-psychologische werken gewoonlijk maken. In hun beschrijvingen van een bepaalde samenleving concentreren ze zich op 'the most prominent situations, the most evident problems, thinking to characterize thereby the life of the given group'. Goede sociologen weten beter; bij hun onderzoek nemen zij altijd 'the whole life of a given society" 44 in aanmerking. Een oud geluid, dat Thomas evenwel in een nieuwe richting ombuigt. Hoe richt men zich namelijk op het maatschappelijk leven als geheel? Door altijd twee soorten van data in het onderzoek te betrekken, luidt Thomas' antwoord. Hij noemt ze tsocial values' en 'attitudes'. Sociale waarden vormen de objectieve zijde van het sociale leven; het zijn de culturele entiteiten waarop ons handelen zich richt. Attitudes verwijzen naar de subjectieve kenmerken van individueel gedrag dat zich op die waarden oriènteert. Dus 'geld' is bij voorbeeld een sociale waarde; de neiging het uit te geven is een attitude.

In deze definiëring ligt besloten dat beide typen data elkaars complement zijn. Niet in de betekenis dat bij elke waarde een bepaalde attitude hoort (de sociale waarde 'geld' kan ook aanleiding geven tot zuinigheid), maar in methodologische zin. leder fenomeen binnen een samenleving is het resultaat van een interactie tussen attitudes en waarden. De oorzaak van een sociaal of individueel fenomeen is derhalve nooit alleen een ander sociaal of individueel fenomeen, maar altijd een combinatie van beide.

Net als bij Ross en Small blijft er bij Thomas zo een nauwe relatie bestaan tussen het psychische en het sociale niveau, zij het dat hij die relatie niet meer primair in een lamarckiaanse context plaatst. Niet de ontwikkeling, de groel van associaties staat centraal, maar hun structuur en interne samenhang.

Tegelijkertijd laat Thomas het met het evolutionaire perspectief verbonden geloof in maatschappelijke vooruitgang niet los. Hij dient dit geloof evenwel anders te legitimeren dan Small c.s. hadden gedaan. De laatsten twijfelden niet aan de mogelijkheid de maatschappij te verbeteren, omdat ze maatschappelijke vooruitgang opvatten als cen directe resultante van de sociale evolutie van de mens. In die sociale evolutie komt de mens tot rede en wordt het meer sociale oordeelsvermogen langzamerhand tot een 'gewoonte' gemaakt. Deze gewoonte 'of letting "I would" wait upon "I approve", zoals Ross het uitdrukt, 'gives society a new opening in its struggle with the antisocial man'. ${ }^{45}$ Mensen laten zich uiteindelijk leiden door hun verlangens, maar gelukkigerwijs komen in de loop van de evolutie sociale verlangens meer voorop te staan.

De sociologie kan dit evolutionaire selectieproces versnellen, meenden Small en Ross. Thomas stemt met die gedachte in, zij het dat in zijn ogen de strijd met 'de antisociale mens' dient te worden verlegd naar een nieuw niveau: sociologie moet zich niet richten op sociale opvoeding, maar op sociale technologie. Want als socioloog kan men niet langer vertrouwen op een progressieve evolutie van de "menselijke natuur". Haar praktisch nut ontleent de sociologie uitsluitend aan het feit dat ze attitudes en waarden in een voor een samenleving gewenste richting kan veranderen.

Maar als het geloof in de veranderbaarheid van de menselijke natuur geen wetenschappelijke rechtvaardiging blijkt te bezitten, dan rijst de vraag op welke gronden we toch kunnen blijven geloven in de mogelijkheid om met behulp van sociologisch 
onderzoek maatschappelijke vooruitgang te bewerkstelligen. Thomas' taxonomie van vier menselijke verlangens, is een antwoord op die vraag. De Polish Peasant is geschreven vanuit de veronderstelling dat aan de verschijnselen van sociale desintegratie die de auteurs in de Poolse gemeenschap in Amerika aantreffen een halt toe te roepen is. Maar die veronderstelling is alleen gerechtvaardigd, zo realiseert Thomas zich, wanneer individuen kenmerken bezitten waardoor zij gewoonweg niet kunnen weigeren in te gaan op de stimulansen die de samenleving hen met het oog op dat doel toedient. Welnu, die kenmerken zijn er inderdaad: elk individu kent in potentie een viertal verlangens die alleen in vervulling kunnen gaan als hij deel uitmaakt van een sociale groep.

De vier verlangens van Thomas zijn universele disposities, de krachten achter onze attitudes. In die zin zijn het meer mogelijkheidsvoorwaarden, dan directe oorzaken voor sociaal gedrag. Als zodanig belichamen ze Thomas' vertrouwen in de veranderbaarheid van menselijk gedrag, in de sociale geneigdheid van de mens. De sociabiliteit van de mens blijft gewaarborgd, ook al is zijn 'natuur' onveranderlijk.

\section{De sociale krachten van Stuart Chapin}

In 1936 verschijnt in de American Joumal of Sociology deze advertentie.

$$
\begin{aligned}
& \text { New techniques for surveying } \\
& \text { and measuring errors } \\
& \text { A mathemanical theory } \\
& \text { providing a philosophy } \\
& \text { for sungers. }
\end{aligned}
$$

\section{A CONTROLLED EXPBRMMENT}

ON RURAL HYGIENE IN SYRLA

$$
\begin{gathered}
\text { A Study in the Measurement of Rural } \\
\text { Culture Patterns and of Social Forces } \\
\text { By STUART C DODD } \\
\text { Professor of Sociolog } \\
\text { American Uhinersiby of Beinit, Syria }
\end{gathered}
$$

I regard this work as one of the finest sociological monographs which has appeared up to the present time. In its own particular field, namely, the technique of measuring social change, it is beyond question superior to anything heretofore published.....

I do not recall having encountered in the whole literature of social research a superior account of exactio what was done, the results achieved, and a full exhibit of the instumenus used.... Brielly, there is here submitted a logical theory for the reduction of the concept of social forces to an equation based on measured entities.

George A Lundberg in "Social Forces"

October 1935

330 pages, 70 "table-graphs" 14 full page illustrations, cloth $\$ 2,75$.

The Oxford University Press, Agents.

Stuart C. Dodd is een leerling van F. Stuart Chapin, de socioloog die in 1935 op de jaarvergadering van de American Sociological Society de sociale krachten onderverdeelde in persoonlijke en onpersoonlijke krachten. Chapin heeft in de jaren twintig het experi- 
ment in de sociologie geïntroduceerd; met sociologen als Lundberg en Ogburn behoort hij tijdens het interbellum tot de belangrijkste representanten van de kwantitatief-experimentele traditie in de Amerikaanse sociologie. Hun lijfblad is het in 1922 opgerichte tijdschrift Social Forces, na het American Joumal for Sociology het tweede algemeensociologische tijdschrift in Amerika. ${ }^{46}$

'Experimentele sociologie' is rond 1920 nog een contradictie in terminus. Pragmatistische filosofen als Dewey en Mead gingen er tot dan toe van uit dat sociologen wel de met het 'experimentele methode' verbonden wetenschappelijke instelling konden overnemen, maar zij meenden niet dat sociologen ook daadwerkelijk experimenten zouden kunnen uitvoeren. Bij de term "experimenteren" denken ook sociologen zelf nog voornamelijk aan het werk dat natuurwetenschappers en psychologen in hun laboratoria verrichten. Vooral het voor hen minder abstracte psychologische experiment beschouwen zij als het modelvoorbeeld van het experimenteren in het algemeen. Er is in het licht van dat model sprake van experimenteren wanneer er binnen een laboratorium cen experimentele situatie wordt opgezet waaraan vervolgens een stimulus wordt toegediend door de experimentator zelf; wanneer alle relevante condities onder zijn controle staan; wanneer de effecten van de stimulus wordt gemeten met instrumenten; en wanneer het experiment naar believen kan worden herhaald.

De oriëntatie op dit model maakt begrijpelijk waarom zelfs lemand als Ogburn (een sinds 1927 aan de universiteit van Chicago verbonden socioloog en statisticus, en als weinig anderen in de sociologie een voorstander van het gebruik van kwantitatieve methoden) experimenteel onderzoek in de sociologie onmogelijk acht. Want daarvoor zijn laboratoriumcondities vereist waarover de socioloog nimmer beschikken kan, redeneert hij. ${ }^{47}$

Deze koppeling tussen experiment en laboratorium proberen Chapin en Lundberg, tezamen met geestverwante sociologen als Bain en Bernard, op drie manieren te doorbreken. Allereerst wordt experimenteren door hen in verband gebracht met verschijnselen buiten het laboratorium. De utopische gemeenschappen van Owen en Fourier noemt Chapin 'natuurlijke experimenten'; bij Bernard heten de Volkenbond, de U.S.S.R. en zelfs de stichting van de Verenigde Staten een 'experiment'; Lundberg vat het uitvalar. digen van wetten en sociale hervormingen op als 'ongecontroleerde experimenten'.48 Overal om ons heen wordt kortom voortdurend geexperimenteerd, ook al waren we ons daarvan tot nog toe niet bewust.

Op de tweede plaats wordt het experimenteren in meer strikte zin geherdefinięerd. Experimenteren, stelt Chapin, "is observation under controlled conditions'. 49 De pointe van deze definitie is dat om te kunnen spreken van een experiment, het nu niet langer nodig is dat de experimentator eigenhandig een stimulus toedient. Die handeling kan ook door anderen (beleidsmakers bij voorbeeld) worden verricht terwijl de experimentator passief toeziet. Daarmee verschuift tevens de betekenis van het begrip 'experimentele controle': the experimenter does not control physically what he wants, he controls mentally by selecting from the environment what he needs', betoogt Chapin. ${ }^{50}$

Tenslotte is er nog een equivalent nodig voor het meetinstrument. Die vindt men in de schaal. In het verlengde van de door psychologen ontwikkelde attitudeschalen beginnen Chapin c.s. met het construeren van schalen voor het meten van sociale afstand, van sociale en economische status, van sociaal aanpassingsvermogen, enzovoort. En de eis 
van reproduceerbaarheid dan? Daar werd vooralsnog niet zwaar aan getild. Chapin en Lundberg beschouwen het niet als een bezwaar dat alle door hen opgezette of door hen besproken sociologische experimenten slechts eenmaal zijn uitgevoerd. Tegenover dit nadeel staat evenwel een voordeel waar Lundberg in zijn bespreking van het boek van Dodd op wijst: sociale verandering wordt nu meetbaar, en wel dankzij the reduction of the concept of social forces to an equation based on measured entities". Eindelijk is de sociologie er in geslaagd sociale krachten, of althans hun effecten, meetbaar te maken! Aan de twijfel of zulke krachten eigenlijk wel bestaan, kan daarmee een einde komen, want dankzij de experimentele methode wordt het nu mogelijk hun werking ondubbelzinnig aan te tonen. Maar hebben de sociale krachten waar Dodd, Chapin en Lundberg over spreken nog wel iets uit te staan met de krachten waar Ward, Small en Ross naar verwezen? Het onderzoek dat Dodd in Syrie heeft verricht, kan wellicht uitsluitsel bieden.

Dodd onderzocht in Syriè het effect van een voorlichtingsprogramma op de hygięnische praktijk van agrarische families. ${ }^{51}$ Eén dorp werd twee jaar lang regelmatig door enkele Amerikaanse verplegers bezocht; drie andere dorpen, die van hygiënische instructies verstoken bleven, functioneerden als controlegroep. Om het effect van de voorlichting te kunnen meten, ontwikkelde Dodd een zogenoemde hygiëneschaal. Dit betekende dat hij eerst een lange lijst met vragen opstelde van het type: vindt $U$ regelmatig handenwassen belangrijk? Vervolgens gaf hij met behulp van de leden van het voorlichtingsteam ieder mogelijk antwoord een aantal 'punten' (bij een totaal te vergeven aantal van 1000), en ijkte hij de vragenlijst in een vooronderzoek (de scores mochten bij voorbeeld niet noemenswaardig worden beinnloed door irrelevante factoren als leeftijd of geslacht). Tenslotte legde hij deze vragenlijst voor aan de dorpelingen en wel voordat en nadat ze aan de voorlichtingscampagne onderworpen werden. Dodd beschouwde het gemiddelde verschil in "punten" tussen beide series antwoorden als een maat voor het effect van de voorlichtingscampagne. Ter controle ondervroeg hij de bewoners van de drie dorpen die geen voorlichting kregen ook twee keer.

Aan deze onderzoeksopzet valt op dat het effect het voorlichtingsprogramma niet door een onderzoek naar verandering in demografische gegevens wordt vastgesteld. In hoeverre de kindersterfte daalt, in hoeverre de frequentie van bepaalde ziektes afneemt, zijn kwesties die bij Dodd geheel buiten beschouwing blijwen. Ook veranderingen in het handelen van de dorpelingen valt buiten zijn gezichtsveld. Wat hij beoogt te meten is louter een verandering in opinie. Daarbij gaat het hem niet om individuele opinies; de maat voor het effect van de voorlichtingscampagne is namelijk een verandering in het gemiddelde puntentotaal van de dorpsgemeenschap als geheel.

Eén niet onbelangrijk element uit het progressief-evolutionair vocabulaire vinden we in deze onderzoeksopzet terug. Volgens sociologen als Small, Giddings en Ross is immers de maat voor sociale vooruitgang de groei van de 'social mind', een ontwikkeling die Ross omschreef als "the disappearance of those suggestions and ideas which are felt to be unfavorable to the social welfare, and the survival and vogue of those which are felt to comport with this welfare'. ${ }^{2}$ Dodds hygiëneschaal meet in feite dit type van ontwikkeling. Het object waarop sociale krachten inwerken is, anders gezegd, hetzelfde gebleven: sociale krachten zijn die krachten die veranderingen teweegbrengen in de geest van een groep. De studie van sociale krachten is bij Dodd dan ook niet toevallig gekop- 
peld aan onderzoek naar het wel en wee van een voorlichtingsprogramma; de hogere sociale krachten worden immers primair via opvoeding opgewekt. Wat verschilt is dat deze krachten niet meer worden geclassificeerd of expliciet worden benoemd. Hoe veranderingen plaatsvinden en op grond van welke principes dat geschiedt, blijft onbesproken. Sociale krachten tonen zich alleen nog in hun (meetbare) effecten op de collectieve waarden van een groep.

\section{De praktische context van taalmutaties}

Het progressief-evolutionair vocabulaire bood Small c.s. de gelegenheid de sociologie te presenteren als een wetenschap. Na 1910 wordt het evenwel steeds moeilijker om met behulp van dat vocabulaire voor de sociologie wetenschappelijke legitimiteit en culturele autoriteit op te eisen. Vernieuwingen leiden echter niet tot een eenduidige bijstelling van de sociologische taal, zo bleek. Het vocabulaire differentieert zich; er ontstaan meerdere varianten, een ontwikkeling waarvan de sociologische leerboeken uit de jaren twintig en dertig de stille getuigen zijn. De lezer krijgt een veelvoud aan soorten van sociale krachten gepresenteerd: fysische en biologische feiten, instituties, individuen, attituden, verlangens, interessen en opinies.

Richten we de aandacht op de globale ontwikkeling van de Amerikaanse sociologie zoals die zich aan de hedendaagse blik voordoet, dan dringt zich snel het beeld van conceptuele wildgroei op. Nemen we daarentegen de lokale situatie van de besproken sociologen als het punt van vertrek, dan blijkt evenwel dat de genese van varianten een allesbehalve blind karakter heeft. De wijze waarop het oorspronkelijke vocabulaire 'muteert', is namelijk nauw verbonden met de manier waarop sociologen reageren op de drie soorten van kritiek die zich rond 1910 aandienen en die ik in de tweede paragraaf van dit hoofdstuk besproken heb. Deze kritiek is daar ingedeeld onder de kopjes "Generalisme of specialisme?', 'Diepe oorzaken of observeerbare effecten?' en 'Opvoeding of onderzoek'. De discussie over de verhouding van de sociologie tot andere wetenschappen (het eerste kopje) leidt ertoe dat sociologen zich expliciet gaan afvragen of hun vak toch niet een eigen object bezit. De discussie over het praktische doel van sociologiebeoefening (het derde kopje) brengt de vraag met zich mee welke maatschappelijke rol de sociologie zou moeten vervullen. De discussie over het nut en de functie van sociologische classificatieprincipes (het tweede kopje) roept de vraag op wat wetenschappelijk redeneren eigenlijk inhoudt. Er dienen zich voor de tweede generatie Amerikaanse sociologen kortom drie vragen aan die ik voor het gemak als volgt zal nummeren. Ten eerste: heeft de sociologie een eigen object? Ten tweede: wat is haar maatschappelijke rol? Ten derde: Wat geldt als wetenschappelijk redeneren?

In deze paragraaf wordt onderzocht in hoeverre respectievelijk Ellwood, Thomas en Dodds leermeester Chapin op deze vragen een nieuw antwoord geven. Daarbij breng ik hun verschillende reacties in verband met de sociale prakijken waarin zij als socioloog hoofdzakelijk werkzaam zijn. 


\section{Ellwood}

Niet op alle universiteiten in de Verenigde Staten ontwikkelt de sociologie zich tijdens het interbellum tot een empirische wetenschap; op cen groot aantal, waartoe tot 1927 ook Harvard behoort, staan cursussen in de sociologie nog geheel in het teken van karaktervorming, wan het ontwikkelen van een sociaal en publiek bewustzijn bij de student. $^{53}$ In een dergelijke context zagen we Ross aan de universiteit van Winsconsin de sociologie beoefenen; in soortgelijke omstandigheden doceert Ellwood decennia later sociologie aan de Duke University.

In die situatie geeft Ellwood alleen op de eerste vraag (heeft de sociologie een eigen object?) een ander antwoord dan zijn voorgangers. Voor Small c.s. heeft sociologie een synthetiserende taak, zo weten we. In hun sociologie worden niet alleen kennis van de psyche en de moral in een meer omvattend verband geplaatst, ze wil tevens de kennis van de economie, het recht, de politiek en de geschiedenis in zich opnemen. Doordat Ellwood 'de groep' verheft tot het object van de sociologie, raken de vier laatstgenoemde kennisgebieden zo goed als buiten beeld. De groep beschouwt hij namelijk primair als de resultante van biologische en (sociaal)psychologische krachten. Bij de term psychische krachten denkt de eerste generatie Amerikaanse sociologen aan krachten die werkzaam zijn via de psyche, terwijl Ellwood ze meer letterlijk als psychologische krachten interpreteert. Omdat in zijn werk de term 'groep' een synoniem blijft voor 'associatie", kunnen we dan ook concluderen dat de constructie van een eigen object voor de sociologie bij Ellwood hoofdzakelijk berust op een versmalling van de referentie van het begrip sociale kracht.

Het oude motief dat de sociologie zich richt op de gehele menselijke ervaring en zich als zodanig tegen elke 'eenzijdige' opvatting verzet, blijft desalniettemin onaangetast in Ellwoods visie op de matschappelijke rol van de sociologie. Op de tweede vraag geeft hijj dan ook géen nieuw antwoord. De sociologische leer van de vooruitgang leidt volgens Ellwood namelijk tot 'de feitelijke conclusie (...) dat wij ons moeten bevrijden van nauwe eenzijdige bewegingen en ontwikkelingen in ons sociale leven. Bijv. de eenzijdige stoffelijke beschaving ten koste van de geestelijke. Dit kan gebeuren door ons met meer toewijding en energie te wijden aan de geestelijke zijde van onze beschaving. In het algemeen wordt onze beschaving bedreigt door eenzijdige bewegingen, die alleen het welzijn van bijzondere klassen en groepen beoogen. Al die eenzijdige bewegingen zijn gegrond op eenzijdige theorieen van den socialen vooruitgang. $\mathrm{Zij}$ berusten op het begrip van de beteekenis van én enkel bestanddeel of voorkomen van ons sociaal leven'.54 Sociologie behoudt zo in Ellwoods variant precies dezelfde ethische strekking als voorheen; ze strijdt tegen 'eenzijdige' theorieên en leert ons hoe de mensheid dient te worden opgevoed ${ }^{55}$

Wat de derde vraag betreft (wat geldt als wetenschappelijk redeneren?) is Ellwood een van degenen die zich in het interbellum verzetten tegen de introductie van kwantitatieve methoden in de sociologie. Wie meent dat de wetenschap louter of hoofdzakelijk bestaat uit kwantitatieve bepalingen van objectieve feiten, vergist zich. Want, zo vervolgt hij, "de belangrijkste stellingen der moderne wetenschap, die betrekking hebben op de evolutieleer, zijn geen quantitatieve bepalingen, maar bepalingen van ontwikkelingsverhoudingen....56 Het gaat in de wetenschap, zegt Ellwood in het verlengde van Spencers $19 \mathrm{e}$-eeuwse wetenschapsopvatting, om het blootleggen van diepere 
classificatieprincipes, niet om het in kaart brengen van feitelijke regelmatigheden. Wetenschap houdt niet zozeer het vergaren, als wel het systematiseren van feiten in.

De bezwaren tegen kwantificering zijn bij Ellwood niet gebaseerd op het hermeneutische argument dat de studie van de menselijke cultuur altijd op een of andere vorm van 'Verstehen' berust - die gedachte dringt tezamen met inzichten uit de wijsgerige fenomenologie pas na 1940 door in de Amerikaanse sociologie. Zijn bezwaren staan in hoofdzaak nog in de context van het progressief-evolutionair vocabulaire, waarin van een methodologische tegenstelling tussen natuurwetenschap en menswetenschap geen sprake is.

\section{Thomas}

De stad Chicago kent sinds het einde van de $19 \mathrm{e}$ eeuw een traditie van op sociale hervormingen gericht empirisch onderzoek, een traditie waarin in eerste instantie vrouwen als Jane Addams en Edith Abbott de leidende figuren zijn. ${ }^{57}$ Met de professionalisering van het sociale werk krijgt ook het empirisch onderzoek een meer professioneel karakter, een ontwikkeling die door het beleid van particuliere charitatieve fondsen wordt gestimuleerd. Instellingen als de al genoemde 'Russell Sage Foundation' en het tot de Rockefeller Foundations behorende 'Laura Spelman Funds' financieren vanaf circa 1910 het merendeel van het sociaal-empirische onderzoek. Ook The Polish Peasant en Thomas' latere studie The unadjusted Girl zijn door charitatieve fondsen gefinancierd, wat vaak een inhoudelijke bemoeienis van deze geldverstrekkers met het onderzoek inhield.

In deze situatie geeft Thomas zowel op de eerste vraag naar het sociologisch object als op de tweede vraag naar de maatschappelijke rol van de sociologie een ander antwoord dan de eerste generatie Amerikaanse sociologen. Ook voor Thomas is "de groep" het object van de sociologie, zij het dat de aandacht zich in dit geval niet richt op de (evolutionaire) genese van groepskenmerken. Sociologie onderzoekt de sociale organisatie van groepen en demarqueert zich van de (sociale) psychologie door het centraal stellen van de relatie tussen de subjectieve kant van de sociale organisatie (de attitudes) en haar objectieve kant (de waarden), betoogt hij.

In deze definitie schuift ook Thomas de economische, politicke en historische dimensies van menselijk samenleven naar de achtergrond. De veranderlijke attituden en waarden op deze gebieden, meent hij, beïnloeden in geciviliseerde samenlevingen slechts indirect 'the existence or coherence of society'ss Alles wat een groep zou kunnen verdelen wordt door Thomas zo in de periferie van het groepsleven geplaatst; op grond van de kern die overblijft, beschouwt hij een groep dan ook al snel als een in essentie harmonieuze gemeenschap. Thomas' sociologische interesse beperkt zich zodoende tot die waarden die binnen een groep algemeen worden gedeeld.

Die gerichtheid op gedeelde waarden tekent bovendien Thomas" opvattingen over de maatschappelijke rol van de sociologie. Weliswaar verliest bij hem de sociologie haar openlijke ethische strekking en wordt haar doel nu omschreven als de verbetering van 'social technique'. Maar dat doel wordt, in vragende vorm, als volgt omschreven. Hoe kunnen we enerzijds 'produce with the help of the existing social organization and culture the desirable mental and moral characteristics in the individuals constituting the group?' En hoe kunnen we anderzijds 'produce, with the help of the existing mental and 
moral characteristics of the individual members of the group, the desirable type of social organization and culture?'59 Wat hier telt als 'wenselijk wordt door Thomas niet nader gespecificeerd. Het spreekt ook voor hem vanzelf dat dit adjectief verwijst naar doelen als eenheid, evenwicht en leven in harmonie met de omgeving.

Naar aanleiding van de derde vraag naar wat telt als wetenschappelijk redeneren, kan worden opgemerkt dat Thomas, net als Park, de sociologie als een ahistorische wetenschap opvat. Het zoeken naar 'ontwikkelingswerhoudingen', naar de principes van de sociale evolutie, komt bij hen in een kwade reuk te staan. Maar voor beiden blijft de sociologie wel de wetenschap die de diepere oorzaken van sociaal handelen kan blootleggen. Sociologie valt daarom ook niet samen met sociale technologie; 'research' betekent voor hen niet alleen het verrichten van empirisch onderzoek, maar omvat ook theorievorming:

\section{Chapin}

Dodds leermeester Chapin slaat juist op dit laatste punt een andere richting in. Deze pleitbezorger van de experimentele sociologie beantwoordt de beide eerste vragen (heeft de sociologie een eigen object?, wat is haar maatschappelijke rol?) op een soortgelijke manier als Thomas. Maar op de vraag wat als wetenschappelijk redeneren telt, geeft hij een ander antwoord. ${ }^{60}$

De traditie van de experimentele sociologie ontstaat op staatsuniversiteiten in landbouwstaten als Minnesota en Missouri. Mede als reactie op de ingrijpende landbouwcrisis die in de jaren twintig het sociale leven in deze staten ontwricht, wijzigt zich op deze universiteiten de praktische rol van de sociologie. In plaats van bij te dragen aan 'public education" wordt nu de verbetering van 'public welfare' het hoogste doel. ${ }^{61} \mathrm{De}$ wijze waarop dit doel wordt vormgegeven is daarbij geent op de experimentele traditie die in de landbouwwetenschap inmiddels is ontstaan. Niet naar analogie van fysische of psychollogische experimenten worden sociologische experimenten ingericht, maar naar analogie van de experimenten die worden verricht op de proefstations voor gewasveredeling. De statistische technieken die in die context door bij voorbeeld Fisher zijn ontwikkeld, worden door Chapin en Dodd rechtstreeks overgenomen, zij het dat zij ze nu voor een ander type van 'veredeling' aanwenden. ${ }^{62}$

Deze oriéntatie wordt nog eens gestimuleerd door het feil dat de groeiende macht van de federale overheid na 1918 allereerst op het gebied van de landbouw in daden wordt omgezet. Nationale welzijnspolitiek begint in de Verenigde Staten op het plattelland, een politiek waarin het federale ministerie voor landbouw een sleutelfunctie krijgt toebedeeld. Via dit ministerie komen in de jaren twintig fondsen beschikbaar waaruit in agrarische gebieden ook sociologen kunnen putten. ${ }^{63}$ De beoordelaars van Chapins onderzoeksvoorstellen waren derhalve in eerste instantie niet sociale hervormers of collega-sociologen, maar op het ministerie van landbouw werkzame landbouwingenieurs.

In deze situatie kiest Chapin voor een statistisch verklaringsmodel zoals dat met name door Pearson en Fisher is ontwikkeld en stelt hij tevens het uitwerken van een op sociologisch experimenteren toegesneden methodologie boven de ontwikkeling van theorie. Tegenover zijn sociologische collega's legitimeert hij deze benadering door haar te presenteren als de noodzakelijke aanvulling op reeds bestaande vormen van sociolo- 
giebeoefening. Experimentele sociologie is meer dan onderzoek naar de 'effectiviteit' van sociaal beleid; doordat ze zich niet richt op de doelen of oorzaken van menselijk handelen, is ze als geen andere vorm van sociologie in staat de onvoorziene en onbedoelde consequenties van menselijk handelen te traceren. Naast de persoonlijke sociale krachten maakt ze aldus tevens de onpersoonlijke sociale krachten tot object van sociologische studie, zoals Chapin in 1935 in zijn openingsrede op het jaarlijkse sociologencongres zegt.

\section{De constructie van een disciplinaire orde}

In dit hoofdstuk is de ontwikkeling van de Amerikaanse sociologie tijdens thet interbellum beschreven in termen van de evolutie van het begrip 'socale kracht'. Het door Small c.s. gehanteerde progessief-evolutionair vocabulaire, waarin dit begrip een centralle plaats inneemt, komt na 1905 onder druk te staan en wordt door sociologen als Ellwood, Thomas en Chapin op verschillende manieren bijgesteld. Uit het oorspronkelijke vocabulaire ontstaan drie verschillende 'mutaties'.

Anders dan bij de evolutie van organismen kunnen we niet zeggen dat deze 'mutaties' of variaties' een blind karakter hebben. Het ontstaan van varianten hangt nauw samen met een differentiatie in de praktijken waarop sociologen zich orienteren, zo kunnen we concluderen. De variaties die tijdens het interbellum in het sociologisch vocabulaire ontstaan, zijn het resultaat van keuzen en beslissingen die in verschillende lokale situaties worden genomen. Daarbij worden sommige elementen uit het oude vocabulaire overgenomen, andere daarentegen geschrapt en door nieuwe vervangen.

De variaties die Ellwood, Thomas en Chapin op het oude vocabulaire aanbrengen blijven tot ver in de jaren dertig naast elkaar bestaan. (Daarna raakt de Amerikaanse sociologie in de ban van het functionalisme van Parsons en Merton. ${ }^{64}$ ) Op het proces van variatie is dus niet onmiddellijk een proces van selectie gevolgd. Maar houdt dat in dat de sociologie ophoudt te bestaan als én discipline? Het antwoord is afhankelijk van het standpunt dat we innemen. Terugkijkend zien we tijdens het interbellum verschillende "stromingen" of "scholen" ontstaan. Hoewel alle door mij besproken sociologen de sociale werkelijkheid blijven ordenen in termen van "sociale krachten", valt ons op dat Ellwood, Thomas en Chapin ieder een eigen weg gaan.

De betrokken sociologen blijven echter over hun vak spreken in termen van eén geordend project. Ook in leerboeken uit die tijd gebeurt dit. Daarin wordt de verscheidenheid aan theorieèn over sociale krachten namelijk gepresenteerd als een indicatie voor het feit dat de sociologie gestaag steeds meer soorten van krachten heeft ontdekt. ${ }^{65}$ Ook in programmatische redes wordt niet de indruk gewekt dat die theorieen op sommige punten met elkaar rivaliseren; ze suggereren veeleer dat sociologen hun taken keurig onderling hebben verdeeld.

Op een ander vlak verandert er wel iets: de wijze waarop sociologen die onderlinge verdeling van taken benoemen, is in 1935 niet meer dezelfde als in 1905. Deze "interne" demarcatiearbeid, het afbakenen van verschillende vormen van sociologie ten opzichte van elkaar, heeft bij voorbeeld bij Chapin een ander karakter dan bij Small, zo bleek. 
Terwijl Small de discipline intern ordent met behulp van het begrippenpaar fysische- en psychische krachten, probeert Chapin de sociologie te ordenen met behulp van de tegenstelling persoonlijke en onpersoonlijke krachten. De disciplinaire orde verandert dus wel. Zulke pogingen om steeds op een nieuwe manier orde te scheppen, kunnen echter niet alleen worden verklaard uit veranderingen in de praktijken waarop sociologen zich orienteren. Uit Chapins oriêntatie op binnen de landbouw ontwikkelde veldexperimenten wordt bij voorbeeld niet onmiddellijk duidelijk waarom hij de sociale krachten in persoonlijke en onpersoonlijke krachten opdeelt. Om de dynamiek van de sociologie als discipline te kunnen traceren, moeten we derhalve nog één nieuw element aan ons verhaal toevoegen.

Een vocabulaire legt de grenzen van het spreken vast en begrenst ook de handelingsruimte van mensen die het hanteren. Toch moeten we hier tussen spreken en handelen enig onderscheid aanbrengen. Wat men in een vocabulaire wel of niet kan zeggen, is niet afhankelijk van plaats en tijd. Maar wat men met een vocabulaire tot stand kan brengen is dat wel. In de aristotelische taal van de middeleeuwse natuurwetenschap kan niet worden onderscheiden tussen massa en gewicht, toen niet en nu niet. In de middeleeuwen kon men echter met die taal veel meer doen dan tegenwoordig. Voor de sociologie geldt iets soortgelijks. Zo stelt in 1905 het vocubulaire dat Small hanteert hem in staat een disciplinaire orde te creëren. Met behulp van de dichtomie fysisch/ psychisch weet hij toenmalige controversen te interpreteren als elkaar aanvullende posities. Maar om dertig jaar later hetzelfde te kunnen doen, schiet dit vocabulaire inmiddels tekort. Niet alleen zijn de problemen veranderd, ook de meningsverschillen lopen niet meer langs oude lijnen. In deze situatie, wanneer met name de kwestie in hoeverre de sociologie een experimentele wetenschap kan zijn de sociologische gemeenschap verdeelt, is voor het aanbrengen van een discipliniare orde een ander vocabulaire vereist. De dichotomie persoonlijk/onpersoonlijk is daarvan een onderdeel; ze maakt het Chapin mogelijk een methodologische controverse te interpreteren als een schijnconflict. De voor- en tegenstanders van de experimentele sociologie richten zich in de versie van de werkelijkheid die dit nieuwe vocabulaire constitueert, eenvoudigweg op twee verschillende gebieden van sociaal handelen.

Small en Chapin ordenen hun discipline zo dat hun eigen standpunten en activiteiten daarbinnen een prominente plaats kunnen bezetten. Maar dat is iets wat iedere wetenschapsbeoefenaar doet. Ook in een tweede opzicht is hun 'interne' demarcatiearbeid weinig opmerkelijk: verschillen van mening worden in de wetenschap vaker verhuld. De algemene conclusie die uit dit hoofdstuk getrokken kan worden, ligt dan ook op een ander vlak. Zoals ik in dit hoofdstuk heb proberen te demonstreren, is het mogelijk binnen zekere historische en nationale grenzen niet-finalistische disciplinegeschiedenis te schrijven zonder dat men de ontwikkeling van de discipline als geheel uit het oog verliest. Een verhaal dat aan die voorwaarde voldoet, zou uit drie lagen moeten bestaan, zo komt bovendien uit dit hoofdstuk naar voren. De eerste laag is die van de individuele variatie: de geschiedenis van de sociologie neemt hier de gedaante aan van een stel intellectuele biografieèn (in mijn gevall van Ellwood, Thomas en Chapin). Op een tweede laag wordt in die individuele variatie naar ordening en continuïteit gezocht: de geschiedenis van de sociologie wordt hier beschreven in termen van transformaties in 
vocabulaire en veranderingen in de oriëntatie op sociale praktijken. Op een derde laag wordt tenslotte aangegeven hoe de betrokken sociologen zelf hun denken en handelen op elkaar proberen af te stemmen: de geschiedenis van de sociologie is hier de geschiedenis van een collectief dat steeds bezig is zijn identiteit te herdefinièren. En dit laatste gebeurt door verhalen en legendes over elkaar aan elkaar te vertellen. 


\section{Noten behorende bij hoofdstuk VI}

1. Toulmin (1972): 359. Hull verschilt op sommige punten van mening met Toulmin; daaraan ga ik hier voorbij. Zie Hull (1988).

2. Ibid: 382 . Toulmin voegt hier uitdrukkelijk aan toe dat dit niet betekent dat menswetenschappelijk onderzoek minder rationeel zou zijn: "to say that any particular activity is "disciplined" and that its historical development can be analyzed in terms of our evolutionary pattern, is not to congratulate it, but is merely to understand its particular rational structure and aim'. Toulmin (1972): 393.

3. Vgl. Boon e.a. (1991).

4. Tussen wetenschapssociologen en wetenschapsfilosofen bestaat op dit punt een opmerkelijke overeenstemming. Zoals post-kuhniaanse wetenschapssociologen zich in hoofdzaak op de studie van wetenschappelijke gemeenschappen zijn gaan richten, zo zijn wetenschapsfilosofen (met uitzondering van evolutionaire kennistheoretici als Toulmin en Hulj) zich voornamelijk gaan concentreren op de ontwikkeling van theorieën. In inleidingen in de wetenschapsfilosofie wordt doorgaans met geen woord gerept over de disciplinaire opbouw van wetenschap. Zie b.v. Chalmers (1981), Cornelissen (1985), Derksen (1980), Koningsveld (1976), De Vries (1985).

5. Small (1906): 55-77.

6. De ledenlijst staat afgedrukt in AJS, 12 (1906-1907): 736-738.

7. Small spreekt over de sociologie, maar bedoelt steeds: de sociologiebeoefening in Amerika.

8. Chapin (1936): 1-11.

9. Ibid.: 2 .

10. Zie Turner/Turner (1990).

11. Small (1907). Voor de reactie van Hoxie zie Hoxie (1907).

12. Hoxie (1907): 748 .

13. Ibid.: 751. Soortgelijke kritiek wordt geformuleerd door Hayes (1911).

14. Zie met name James (1907), lecture IV.

15. Hoxie (1907): 753 .

16. Small (1907): 4.

17. Zie Cravens (1978): 108.

18. Ibid.: 89.

19. 'Argument under certain conditions is a greater labor-savor than blows, and in it the group interests more fully unfold themselves. But beneath all the argument lies the strength. The arguments go no father than the strength goes.' Bentley (1908): 381. Over Bentley's bijdrage aan de politieke wetenschap zie Dowling (1960); Hale (1960).

20. Bentley (1908): 36. Vgl. het artikel van de politicoloog Ford die in $1908 \mathrm{fel}$ uithaalt naar de pretenties van socilogen. Hij reageert ondermeer op een uitspraak van Ross, die in boek The Foundations of Sociology van de sociologie zei: 'It aspires to nothing less than the suzerainty of the special social sciences. It expects them to surrender their autonomy and become depencies, nay even provinces of sociology'. (Ross (1905): 8-9). Ross voorzag weliswaar dat deze pretentie weerstanden op zou roepen, maar niet, aldus Ford, dat daar ook alle reden toe is. Want waar sociologen als Ross en Small ons eigenlijk toe uitnodigen is het terugkeren naar oude fouten. Terwijl de politieke wetenschap zich langzaam heeft ontworsteld aan de 18e-eeuwse politieke filosofie, valt de sociologische denkwijze nog zo goed als geheel met die van Rousseau en Locke samen. Politieke en socialle fenomene interpreteren sociologen nog altijd als het resultaat van individuele activiteiten; de vorming van het individu gaat bij hen nog 
altijd aan staatsvorming vooraf, de doctrine van het natuurrecht is nog altijd hun uitgangspunt. (Ford (1909): 96-105):

21. Zie Wilson (1990), Brozek (1984).

22. Vgl. Bannister (1987): 151.

23. Publications of The American Sociological Society (1913): 159-168.

24. Ibid.: 159.

25. Ibid.: 166 .

26. Zie voor Parks intellectuele biografie Matthews (1977), Hellmes-Hayes (1987). Vgl. ook Koenis (1991).

27. Publications of ASS (1913): 167.

28. Zie voor deze geschiedenis Hofstadter (1963); Karl (1963).

29. Over de belangrijke rol van 'foundations' voor de ontwikkeling van het toegepaste sociaal-wetenschappelijk onderzoek zie Bulmer/Bulmer (1981), Samelson (1985). De geschiedenis van de Russell Sage Foundation is geschreven door Glenn et.al. (1947).

30. Over de neergang van de 'social survey' als sociaal-wetenschappelijke onderzoeksmethode, zie Bulmer (1991).

31. Zie b.v. Parsons (1959).

32. Dit is de teneur van Bryant (1985) en Wright Mills (1959). Mills viel overigens de generatie van Cooley, Giddens, Small en Ross ook fel aan: in hun progressiefevolutionaire benadering werden alle matschappelijke conflicten met de mantel der liefde bedekt, vond Mills. Zie Mills (1943).

33. Voor deze reconstructie heb ik o.a. gebruik gemaakt van House (1925-1926).

34. Ellwood (1939): 94.

35. Ibid.: 34.

36. Ibid.: 30.

37. Ibid.: 34 .

38. Ibid.: 4.

39. Ibid.: 33.

40. Vgl. ook Ellwood (1909).

41. Coser (1971): 511 .

42. Bulmer (1985): 10.

43. Thomas (1907): 316 .

44. Thomas/Znaniecki (1918-1920): 18.

45. Ross (1901): 325.

46. De oprichters van Social Forces verklaren in hun beginselverklaring ondermeer afstand te zullen nemen van de orientatie op publieke opvoeding: 'What public education was to the last half of the century in the development of democracy, public welfare may well be to the first half of this century, and it seems entirely probable that the organization and technique of public welfare will constitute the outstanding contribution of the twentieth century toward progress in American democracy. By public welfare is meant not simply "welfare" or "human welfare", but the very definite service of democratic government which provides organization, technique and means for making democracy effective in extended application as well as in ideals, written laws, and statutes'. Social Forces 1 (1922): 57.

47. Zie de notulen van de zogenoemde Hannover Conferentie, 20 augustus 1928.

48. Zie Chapin (1917), Bernard (1925), Lundberg (1942).

49. Gecit. in Greenwood (1945): 13.

50. Ibid.

51. Dodd (1934): 327.

52. Ross (1901): 327.

53. Tot 1931 doceert op Harvard F.G. Peabody deze vorm van sociologie onder de naam 'social ethics'. Zie Potts (1965).

54. Ellwood (1939): 385. 
55. Wanneer de kennisvergaring en het altruïsme of de goede will de twee groote sleutels voor den socialen vooruitgang zijn, die onmiddellijk binnen onze beheersching liggen, dan worden de milddelen om deze psychische processen sociaal te handhaven en te beheerschen voor den socialen vooruitgang een zaak van groot belang. Het is duidelijk, dat het middel in het proces der sociale opvoeding ligt, wanneer wij deze gedachte gebruiken om alles aan te duiden, wat er toe bijdraagt om de gewoonten in het karakter der menschen te vormen. Den grooten dienst, die Ward de sociale wetenschappen bewees, was aan te toonen, dat de opvoeding het eerste middel is voor den vooruitgang van de maatschappij.' Ellwood (1939): 381.

56. Ibid.: 3. Zie ook Ellwood (1930).

57. Voor de rol die deze vrouwen in Chicago speelden, zie Deegan (1988).

58. Thomas/Znaniecki (1918-1920): 35.

59. Ibid.: 20.

60. Vgl. Chapin (1947).

61. Zie noot 45 .

62. Zie voor deze verbanden Martindale (1976), Gray (1951), Fine/Severance (1985).

63. Vgl. Karl (1963), Dupree (1980): 151-183.

64. Zile over deze 'revolutie' Kuklick (1973). De opmars van het functionalisme betekent trouwens niet dat de oudere vormen van het sociologisch vocabulaire volledig worden weggevaagd. Zo presenteren sociologen en sociaal-psychologen tot de dag van vandaag typologieen van menselijke 'basisbehoeften'.

65. Zie b.v. Park/Burgess (1921); Reuter/Hart (1933). 
TRADITIES, DISCIPLINES EN DE SOCIOLOGIE

\section{Een methodologie voor historisch onderzoek naar disciplines}

In een reclamefilmpje voor tomaten rolt op een witte ondergrond eerst eén tomaat in beeld. Ze wordt al snel gevolgd door enkele andere tomaten die allemaal een kronkelig pad afleggen voordat ze rustig tegen de pionier aan gaan liggen. Terwijl dit gebeurt komen steeds grotere aantallen vruchten aangezet en nadat de turbulentie van hun beweging ook is uitgedoofd, blijkt zich op het beeld ineens uit de massa van tomaten eén grote tomaat te hebben gevormd. Een klein wonder is geschied, althans voor degenen die niet weten hoe zo'n filmpje wordt gemaakt. Men groepeert al die vruchten eerst in de uiteindelijke vorm en haalt vervolgens per beeldje een of meerdere weg. De film die zo ontstaat, wordt dan bij vertoning in omgekeerde richting afgedraaid.

Verhalen over het ontstaan en de ontwikkeling van wetenschappelijke disciplines hebben lange tijd een grote mate van overeenkomst met dit filmpje vertoond. Een leeg maar reeds klaar liggend werkterrein zien we langzaam gevuld raken met vakgenoten die ieder de voor hen gereserveerde plaats innemen. Welke dwaalwegen ze ook hebben afgelegd en hoezeer ze ook geprobeerd hebben elkar in de weg te zitten, uiteindelijk blijken zij de deelnemers te zijn geweest aan een project waarvan de contouren langzaam zichbaar zijn worden. In deze disciplinaire geschiedenissen herhaalt zich zo het kleine wonder vit de reclamefilm: het handelen van de betrokken wetenschappers lijkt vanuit de uitkomst van hun handelen gecoordineerd te zijn geweest.

In dit boek is geprobeerd een deel van de sociologische disciplinegeschiedenis wat minder mysterieus te maken. Ik heb me afgevraagd hoe er een dísciplinaire orde kon ontstaan die 'sociologie' is gaan heten, zonder aan te nemen dat de handelingen van de makkers van die orde door een vooraf gegeven doel zijn gestuurd. In traditionele disciplinegeschiedenissen wordt het werk van onderzoekers uit het verleden geinterpreteerd vanuit de plaats die hen wordt toegedicht in de globale ontwikkeling van het vak, zoals die zich aan de hedendaagse blik voordoet. De niet-finalistische geschiedschrijving die ik bedreven heb, kiest daartegenover de lokale situatie van de onderzochte en diens tijdgenoten als punt van vertrek, zonder te prejudiceren op latere ontwikelingen die het handelen van de onderzochten niet konden leiden, maar die hooguit mede als -wellicht onbedoeld- resulltaat van hun handelen zijn ontstaan. Deze aanpak maakte het mogelijk in de studie naar de sociologie als wetenschappelijke discipline een viertal problemen centraal te stellen, ic. de problemen van identiteit, continuitteit, legitimiteit en autoriteit.

Mijn niet-finalistische interpretaties van elementen vit de vroege geschiedenis van de Duitse en Amerikaanse sociologie veronderstellen een methodologie van ideeënhistorisch onderzoek. Op grond van deze methodologie is disciplinevorming hier gereconstrueerd 
met behulp van een drietal begrippen: de demarcatie-arbeid die de makers van een discipline verrichten, het vocabulaire waarvan zij zich bij die arbeid bedienen, en de praktijken waarop zij zich orienteren. Ik begin dit hoofstuk met een systematische bespreking van dit begrippenapparaat. Vervolgens probeer ik een aanzet te geven tot theorievorming over intellectuele disciplines. De contouren van een theorie over disciplines schets ik in het tweede deel van dit hoofdstuk. In het derde en laatste deel vormt deze theorie het decor voor mijn samenvattende bespreking van de genoemde vier problemen van disciplinevorming. De geschiedenis van de Duitse en Amerikaanse sociologie beschrijf ik hier als een geschiedenis van de omgang met de problemen van identiteit, continuîteit, legitimiteil en autoriteit.

\section{Demarcatiearbeid}

Filosofen en sociologen hebben bij herhaling gezocht naar de unieke en essentiële eigenschappen van wetenschapsbeoefening, naar kenmerken die haar doen onderscheiden van andere soorten van intellectuele activiteit. Comte demarqueerde positieve wetenschap van theologie en metafysica met behulp van zijn evolutionaire wet van de drie stadia: alleen wetenschap zoekt, door middel van redeneren en observeren, naar regelmatigheden en gelijkenissen. Popper presenteerde 'falsificatie' als een demarcatiecriterium voor wetenschap: alleen theorieen die empirisch te weerleggen zijn, verdienen het adjectief 'wetenschappelijk'. Merton probeerde wetenschap meer sociologisch te definiëren door haar bijzondere karakter aan de werking van een viertal institutionele normen toe te schrijven: de beoefening van wetenschap zou in het teken staan van wat Merton communisme, universalisme, belangeloosheid en georganiseerd skepticisme noemde.

Al deze demarcatievoorstellen hebben veel discussie losgemaakt. Comtes evolutionaire wet werd nog tijdens het interbellum heftig geattaqueerd -bij voorbeeld door Scheler. Poppers voorstel staat sinds de jaren zestig onder wetenschapshistorische kritiek en veel wetenschapssociologen hebben in de afgelopen decennia gewezen op de tekortkomingen van Mertons institutionele demarcatie van wetenschap."

Alle deze debatten hebben iets ironisch, zo heeft de wetenschapssocioloog Thomas Gieryn opgemerkt. Terwijl wetenschapsfilosofen en wetenschapssociologen redetwisten over manieren om wetenschap te demarqueren van niet-wetenschap, wordt elders dat onderscheild ledere dag routinematig aangebracht. Tijdschriftredacties wijzen artikelen af omdat ze niet aan "wetenschappelijke eisen" voldoen, instellingen als N.W.O stellen richllijnen op voor subsidieaanvragen, facultaire wetenschapscommissies bepalen welke publicaties beschouwd kunnen worden als 'bijdragen aan de wetenschap', etcetera. In deze contexten is demarcatie niet slechts een analytisch oftewel theoretisch probleem, maar ook (en vooral) een praktische kwestie. Dat wil zeggen: hoe en waar de demarcatie wordt aangebracht, beinvloedt iemands kansen op het maken van carrière, het aantrekken van fondsen en het verwerven van invloed en status. Gezien de professionele belangen die aldus achter demarcatievraagstukken schuil gaan, is het begrijpelijk dat wetenschappers zich inspannen om hun werk als 'echte' wetenschap te presenteren. Gieryn spreekt in dit verband van hun demarcatiearbeid, die hij omschrijft als het met retorische middelen aanbrengen van een contrast tussen de wetenschappelijke" activiteiten die men zelf verricht en de 'onwetenschappelijke' activiteiten van anderen. ${ }^{2}$ 
Op grond van een aantal gevalsstudies onderscheidt Gieryn drie doelen van demarcatiearbeid. Deze arbeid kan ten eerste in het teken staan van het streven naar expansie: wetenschappers begeven zich op gebieden die door andere disciplines zijn bezet Demarcatiearbeid kan in de tweede plaats gericht zijn op het verwerven van een monopoliepositie binnen een bepaald onderzoeksgebied. En tenslotte kan ze tot doel hebben de autonomie te beschermen van de eigen discipline of professie. Met deze drie doelen correspenderen volgens Gieryn drie retorisehe stijlen. In het eerste geval worden de activiteiten van concurrerende professies in een ongunstig daglicht gesteld; in het tweede geval probeert men van onwelgevallige 'insiders' buitenstaanders te maken door ze te etiquetteren als 'deviant' of als 'amateur', in het derde geval is demarcatiearbeid er op gericht het 'eigenlijke' wetenschappelijke werk af te grenzen van allerlei vormen van 'toepassing".

Analyse van de inhoud van wetenschappelijke demarcatiearbeid maakt duidelijk dat 'wetenschap' geen eenduidige betekenis kent, vervolgt Gieryn. De karakteristieken die eraan worden toegekend, varièren sterk en zijn vaak afhankelijk van datgene waarvan men zich via demarcatiearbeid wil afgrenzen. Wie wetenschap contrasteert met religie benadrukt het belang van empirische feiten; wie wetenschap contrasteert met journalistiek benadrukt het belang van theoretische verklaringen. De grenzen die getrokken worden zijn flexibel en soms zijn de aan "wetenschap" toegeschreven kenmerken met elkaar in tegenspraak. Zulke ambiguïteiten hangen samen met het karakter van demarcatiearbeid, merkt Gieryn vervolgens op. Ambiguinteit ontstaat doordat demarqueren meestal een strijd op meerdere fronten behelst en men op ieder front andere wapens inzet. Ambiguinteit ontstaat bovendien doordat demarcatiearbeid meestal op meer doelen tegelijk is gericht, ook al vereist ieder doel het aanbrengen van een ander contrast. Wie bij voorbeeld zijn eigen professionele autonomie wil beschermen is geneigd het onderm scheid tussen fundamentele en toegepaste kennis te accentueren, wie streeft naar expansie relativeert veelal dat verschil. Ambiguiteit ontstaat tenslotte doordat cen discipline of professie meestal geen gesloten front vormt: aangebrachte contrasten worden door anderen weer uitgevlakt.

Gieryns aandacht is gericht op het aanbrengen van onderscheidingen tussen wetenschap en niet-wetenschap. Maar hij vermoedt dat zijn analyses ook bruikbaar zijn voor onderzoek naar andere vormen van demarcatiearbeid. Ook in het werk dat gericht is op het demarqueren van disciplines, specialismen of theoretische stromingen, zouden we de genoemde drie doelen en daarmee verbonden stijlen moeten kunnen onderscheiden.

Dit boek laat zich lezen als een bevestiging van Gieryns vermoeden. Wanneer demarcatie van de sociologie in het teken van expansie staat, zoals bij voorbeeld bij Small, dan worden concurrerende benaderingen gekarakteriseerd als 'oppervlakkig', 'eenzijdig' of 'beperkt'. Wannneer de demarcatie is gericht op de expansie van een nieuw specialisme of theoretische stroming binnen de sociologie, zoals bij Chapin, dan krijgen concurrerende stromingen een ondergeschikte plaats toegewezen door ze te typeren als 'normatief.

Staat de demarcatiearbeid in het teken van het verwerven van een monopoliepositie, dan zien we inderdaad dat opponenten via retorische middelen terzijde worden geschoven. De Amerikaanse aanhangers van Spencer noemen de beoefenaren van Sociale Wetenschap 'amateurs', Small typeert op zijn beurt Spencer als een 'amateur' en L. von 
Wiese aarzelt niet critici van zijn 'Beziehungslehre' als 'ideologen' te bestempelen.

Volgens Gieryn treffen we het soort demarcatie-arbeid dat gericht is op de bescherming van de eigen autonomie vooral na de tweede wereldoorlog aan. Zodra er meer aandacht komt voor de negatieve maatschappelijke effecten van wetenschap, gaan wetenschappers hun autonomie ondermeer beschermen met het maken van een streng onderscheid tussen 'zulvere' en 'toegepaste' wetenschap. Deze derde stijl van demarqueren treffen we in mijn studie inderdaad niet aan: demarcatie van de sociologie staat voor de tweede wereldoorlog nog hoofdzakelijk in het teken van het verwerven van autonomie.

De ambiguiteit wan door demarcatie-arbeid aangebrachte grenzen is in dit boek vooral in hoofdstuk III ter sprake gebracht. Om een contrast met "amateurs" te creëren presenteert Small de sociologie als een discipline, maar om een verschil met andere menswetenschappen aan te brengen benadrukt hij het brede en integratieve perspectief van de sociologie. Het socialisme stelt Small tegenover wetenschap', maar in zijn strijd tegen het sociaal darwinisme accentueert hij de progressieve betekenis van de sociologie. Inderdaad, zulke ambiguïteiten ontstaan doordat Small met meerdere oogmerken op meerdere fronten werkzaam is.

Ondanks al deze bevestigingen van Gieryns wetenschapssociologische hypotheses, laat dit boek zich ook lezen als een kritiek op zijn benadering. Bij het samenvatten van de resultaten in Gieryns termen treedt immers aanzienlijk informatieverlies op. Niet alleen vallen de verschillen weg tussen de demarcatiearbeid van Sanborn, Spencer, Small, Schmoller en Scheler, belangrijker is nog dat binnen Gieryns kader niet goed te verklaren is waarom bij voorbeeld Smalls demarcatiewerk in het teken staat van disciplinevorming en dat van Weber niet, of waarom Weber niet alleen de autonomie van de wetenschap wil vergroten maar evenzeer die van de politiek.

Gieryn plaatst demarcatie bovendien geheel in het teken van intellectuele strijd en onderlinge rivaliteit tussen tradities. In al zijn voorbeelden zijn wetenschappers in de aanval of de verdediging. $\mathrm{Bij}$ de vestiging van een discipline of een nieuw paradigma heeft demarcatiearbeid inderdaad doorgaans een militant karakter. Maar in andere omstandigheden kan die arbeid er juist op gericht zijn de verhoudingen tussen tradities, disciplines of wetenschappelijke gemeenschappen te pacificeren. ${ }^{3}$ De sociologie presenteren als een specialisme, zoals $\mathrm{L}$. von Wiese doet, is daar een voorbeeld van. Ook de in hoofdstuk I besproken legpuzzel- en de lokettheorie van disciplines zijn voorbeelden van dit type demarcatie. Door het aanbrengen van een arbeidsverdeling tussen vakgebieden of het credren van een eigen nis daarbinnen is men in staat de wetenschappelijke orde en vrede te herstellen.

Dat het demarcatievraagstuk ook een praktische dimensie kent, wordt door Gieryn terecht onderstreept. Maar zoals dat wel vaker bij wetenschapssociologen het geval is, krijgt het begrip 'praktisch' bij hem een te enge omschrijving: bij demarcatie is niet alleen de carriere of de status van personen in het geding, ook de toekomst van een vak of het gezag van een theorie staat op het spel. Demarcatie staat ook altijd in een ideeenhistorische context.

Gieryns sociologische aandacht voor de structuur van demarcatiearbeid leidt bovendien tot een onjuiste typering van de inhoud van deze arbeid. Hij merkt op dat verschillende vormen van demarcatie vaak geen coherent geheel vormen, maar ziet over 
het hoofd dat 'coherentie' geen tijdloze eigenschap is. Smalls demarcatievoorstellen, zo is in hoofdstuk III aangetoond, spreken elkaar binnen de ideeenhistorische context van zijn progressief-evolutionair vocabulaire niet tegen; die voorstellen worden incoherent, zo bleek in hoofdstuk VI, wanneer er veranderingen optreden in de oorspronkelijke intellectuele en praktische contexten waarin Small zijn demarcatiearbeid verrichtte.

Wetenschap krijgt niet vanzelf vorm en disciplines ontstaan niet zonder de inspanningen van talrijke academici. Een niet-finalistische reconstructie van de ontwikkeling van wetenschap kan het daarom niet stellen zonder het begrip 'demarcatiearbeid'. Maar het gebruik van dit begrip wordt pas zinvol in relatie tot twee andere begrippen die in dit boek zijn geïntroduceerd: 'vocabulaire' en 'praktijk".

\section{Vocabulaires}

Met de introductie van het begrip vocabulaire' is in dit boek niet alleen aandacht gevraagd voor de betekenis van taal bij wetenschapsbeoefening, de keuze voor dit begrip impliceert ook een opvatting over taal. Volgens de wittgensteiniaanse traditie waarop ik mij baseer, dienen we taal niet op te vatten als een in principe transparant medium dat het mogelijk maakt om in direct contact te treden met de wereld buiten ons. In dat geval gaan we er vanuit dat taal iets is wat als het ware tussen ons en de wereld in staat, terwijl taal veeleer datgene is waarin zo'n onderscheild tussen 'ons' en 'de wereld' pas te maken valt. Zien we eenmaal in dat we in taal altijd over de relaties tussen ons en de wereld spreken, dan kunnen we er niet simpelweg van uitgaan dat de betekenis van woorden wordt vastgelegd door de objecten waarnaar zij refereren. Maar hoe komt betekenis dan tot stand? Wittgensteins bekende oplossing voor dit probleem luidt dat de betekenis van woorden besloten ligt in hun gebruik binnen een 'taalspel'. Betekenis heeft een conventioneel karakter, niet in de zin dat de betekenis van woorden berust op bewust gemaakte afspraken tussen mensen, mar in de zin dat de regels van een taalspel niet door 'de wereld buiten ons" worden vastgelegd, zelfs niet wanneer dat taalspel 'wetenschap' heet.

Mijn begrip van 'vocabulaire' stoelt niet alleen op deze wittgensteiniaanse betekenis. theorie, ze veronderstelt ook een waarheidstheorie die Wittgensteins stempel dragt. Het uitgangspunt daarvoor luidt niet dat er 'alleen maar' taalspelen bestaan. 'De wereld buiten ons" ligt inderdaad buiten ons, maar 'waarheid' is geen eigenschap van die wereld. Alleen onze beschrijvingen van die wereld kunnen waar of onwaar zijn. Hebben we eenmaal dit verschil aangebracht, dan kunnen we vervolgens de vraag stellen wat zulke beschrijvingen dan wel waar of onwaar maakt. Niet 'de wereld buiten ons', luidt het wittgensteiniaanse antwoord. Kunnen mensen dan eenvoudigweg besluiten of een uitspraak al dan niet waar is? Ook dat niet. Het gaat niet om een keuze tussen 'realisme" of "relativisme'; de indruk dat we tussen die beide mogelijkheden moeten kiezen ontstaat alleen wanneer we afzonderlijke uitspraken uit hun context lichten en daarbij vergeten dat uitspraken altijd worden gedaan in een vocabulaire dat een collectief karakter bezit. Ze veronderstellen anders gezegd een taalspel dat niet alleen de betekenis van woorden vastlegt, maar ook gebruiken en procedures omvat voor het toekennen van waarheidswaarden. Alleen binnen het kader van zo'n taalspel kan over de waarheid van uitspraken worden beslist. Dat kader zien we evenwel vaak over het hoofd, zeker wannneer het ons eigen vocabulaire betreft: sommige regels lijken dan zo 
evident, dat we het conventionele karakter ervan niet doorzien.

Het conventionele karakter van wetenschap laat zich filosofisch beargumenteren, maar het kan ook historisch worden aangetoond. De manier waarop dat in dit boek is geprobeerd, is allesbehalve origineel Mijn interpretatie van vocabulaires' draagt niet alleen een filosofisch stempel, mijn omgang met dit begrip is bovendien geent op het werk van een aantal bekende ideeenhistorici.

Met het werk van Thomas S. Kuhn als voornaamste leidraad is in het voorgaande onderzocht in welke zin vocabuliares het handelen van wetenschapsmensen reguleren. ${ }^{5}$ De taal van de sociale krachten waar Small c.s. mee werken geeft niet alleen inhoud aan hun demarcatiearbeid, zo kwam ondermeer uit dit onderzoek naar voren. Die taal maakt het tevens mogelijk beschrijvend-statistische studies (sociografische arbeid) te verbinden met abstracte theorievorming (het classificeren van krachten); en ook kan binnen die taal ethiek worden opgevat als een inherent onderdeel van sociale wetenschap. Webers onderscheid van wetenschap en moraal is geen 'bruut feit', zo bleek, maar onderdeel van een neo-kantiaans vocabulaire waarin de transcendentale vraag naar de geldigheid van waarden wordt losgekoppeld van de empirische vraag naar het gelden van waarden.

In deze kuhniaanse analyse van historisch taalgebruik wordt taal, zoals eerder is opgemerkt, niet als een medium maar als een instrument opgevat. Om (natuur)wetenschap van eeuwen her te kunnen begijpen moet de historicus vertrouwd raken met vroegere instrumenten. Door taal daarmee te vergelijken worden we erop geattendeerd dat voor vroegere theorieën hetzelfde geldt: theorieèn begrijpen we pas wanneer we de vaardigheid bezitten ermee om te gaan. De taal-als-instrument metafoor geeft aldus aan wat het betekent een taal te beheersen, namelijk: weten wat je er mee kunt doen.

Wanneer we taal beschouwen als een instrument, dan ligt het in de rede het schrijven van een tekst op te vatten als een (taal)handeling. Als geen ander heeft de ideeënhistoricus Quentin Skinner deze analogie tot uitgangspunt gekozen voor zijn methodologie van intellectuele geschiedenis. Sporen van deze methodologie zijn op verschillende plaatsen terug te vinden in dit boek. ${ }^{6}$

Om te beginnen is geprobeerd een 'tekstualistische' benadering van de sociologische disciplinegeschiedenis te vermijden, dat wil zeggen: intellectuele geschiedenis heb ik niet opgevat als het goed lezen van de teksten die grote denkers ons hebben nagelaten. De aandacht voor de teksten van 'grote denkers', bij voorbeeld om daarin de ontwikkeling van een 'idee' te traceren, heeft tot allerlei vormen van historiografische mythevorming geleid, betoogt Skinner. Maar zells wanneer de tekstualist die valkuillen weet te omzeilen, schiet zijn gerichtheid op teksten of ideeën 'an sich' op een essentieel punt te kort: hij weet niet goed raad met de (retorische) dubbelzinnigheden die we in historische teksten vaak aantreffen. Skinner geeft het volgende voorbeeld. ${ }^{7}$ Stel dat we onderzoek doen naar de geschiedenis van het begrip 'nobilitas' en dat we in een tekst uit de Renaissance de uitspraak tegenkomen: 'De militaire aristocratie vertoont bij uitstek nobel gedrag.' De betekenis van deze zin is afhankelijk van de vraag wat de auteur met deze uitspraak heeft bedoeld. Meent hij wat hij zegt, of had hij de intentie het hele begrip 'nobilitas' in discrediet te brengen? Door deze vraag te stellen wordt duidelijk dat kennis van de betekenis van een begrip binnen een bepaald zinsverband ons nog geen uitsluitsel geeft over de betekenis van een uitspraak. Skinner verheldert dit verschil met behulp van de taaldadentheorie van J.L. Austin. Wanneer we taalgebruik pragmatisch 
bezien dan dienen we volgens deze theorie een onderscheid te maken tussen twee soorten van betekenis: de locutionaire of semantische betekenis wan woorden, zinnen en teksten, en de illocutionaire kracht van de taaldaden die met die woorden, zinnen of teksten worden uitgevoerd. Wanneer we een historische tekst, of delen daaruit, willen begrijpen, dan is het niet voldoende om de locutionaire betekenis er van te achterhalen, concludeert Skinner. We zullen tevens moeten weten wat de auteur in die tekst aam her doen was. Daartoe dienen we de illocutionaire kracht, of zoals Skinner liever zegl, de pointe van een tekst te achterhalen. Maar dat is slechts mogelijk, vervolgt hij, indien de historicus buiten de grenzen van de tekst treedt. Pas tegen de achtergrond van de intellectuele conventies in een bepaalde tijd, kunnen we inzicht krijgen in de intenties van taaldaden en laat zich de pointe van teksten reconstrueren.

Terwijl tekstualisten niet toekomen aan het achterhalen van de pointe van een uitspraak of een tekst, slaan contextualisten die stap vaak over, betoogt Skinner. Dat gebeurt met name wannneer de betekenis van teksten geheel en al uit de sociale context of de politieke motieven van auteurs worden verklaard, alsof kennis van de oorzaken van een handeling equivalent is met het begrijpen van de handelling zelf. Maar wie iemands motieven kent voor het schrijven van een tekst, heeft daarmee nog niet de strekking, de pointe van die tekst zelf achterhaald. Wie de betekenis van teksten direct uit sociale contexten verklaart, heeft onvoldoende aandacht voor het feit dat ze altijd zijn gesitueerd in een netwerk van andere teksten. Ze zijn geschreven in een bepaald vocabulaire, ze staan in een traditie of willen zich daar juist van losmaken; ze reageren op teksten uit een ver verleden of negeren vroegere teksten juist bewust, etcetera. De historicus die de pointe van een tekst traceert, kijkt niet bij een auteur naar binnen om daar te zoeken naar 'belangen' of 'drijfveren'; de historicus kijkt als het ware met hem mee naar buiten: het gaat er om de betrekkingen tussen die tekst en andere teksten te onderzoeken.

Skinner legitmeert tegenover (radicale) contextualisten aldus het belang van ideeen geschiedenis. Maar, zo voegt Skinner daar in de richting van tekstualisten aan toe, ideeèngeschiedenis dient meer te zijn dan een geschiedenis van ideeèn. Ideeën hebben buiten een discussie geen bestaan en omdat de taal waarin gedebatteerd wordt niet eeuwenlang dezelfde blijft, bestaan er ook geen eeuwigdurende problemen. Er bestaan louter auteurs die binnen een raamwerk van in taal neergelegde conventies taaldaden verrichten en het is de taak van de intellectuele historicus om via het vergaren van inzicht in dergelijke (veranderende) conventies te achterhalen in welke discussies auteurs intervenièren.

Skinners methodologie heeft in deze studie tot een andere ordening van de geschiedenis van de sociologie geleid. Anders dan in veel vormen van sociologische disciplinegeschiedenis gebeurt, heb ik 'tekst' en 'context' niet als twee aparte categorieën geîntroduceerd. Dit dualisme is vermeden door het werk van de in dit boek besproken auteurs dadelijk als taaldaden te interpreteren. Dit boek laat zich dan ook lezen als een onderzoek naar de pointes van intellectueel handelen. Ik noem er enkele.

In hoofdstuk II is gewezen op een belangrijke pointe van Spencers synthetische filosofie: dit werk stond voor Spencer zelf in het teken van de ontwikkeling van een wetenschappelijke moraal. De sociologie van Ward, komt in een ander licht te staan, zo is in hoofdstuk III betoogd, wanneer we ons rekenschap geven van de egalitaire pointe 
van zijn project. En Smalls sociologie begrijpen we onvoldoende, zo kwam in hetzelfde hoofdstuk naar voren, zonder de ethische pointe ervan in ogenschouw te nemen. Thomas introductie van vier uniwersele menselijke verlangens begrijpen we beter, wanneer we de pointe van deze taaldaad in onze beschouwing betrekken, zo bleek in hoofdstuk VI. In Thomas' classificatie lag de intentie besloten om de veranderbaarheid van mensen, een basispremisse uit het progressief-evolutionaire vocabualaire, een niet-lamarckiaanse rechtvaardiging te verschaffen.

De taaldadentheorie waarop Skinner zich baseert, stelt ons in staat een duidelijk onderscheid te maken tussen contextualistische invloeden en doeleinden die aan intellectuele arbeid vooraf gaan en de doelen of intenties die in die arbeid besloten liggen. Onderzoek naar het eerste is een onderzoek naar contingente factoren, naar de (causale) oorzaken die achter een taaldaad schuil gaan. Onderzoek naar intenties die in het verrichten van taaldaden besloten liggen, i.c. het zoeken naar de pointes van teksten, is daarentegen een vorm van hermeneutiek. In dit laatste geval kunnen we niet zeggen dat de intentie aan de handeling vooraf gaat, ze is er veeleer een inherent onderdeel van. Het achterhalen van zulke intenties vereist daarom altijd een interpretatie van de handeling zelf. Dit onderscheid is niet zonder belang. Het maakt ons er van bewust dat teksten niet alleen in een context staan, maar dat zij ook in contexten kunnen ingrijpen. Want op grond van hun pointes, hun illocutionaire kracht, kunnen teksten perlocutionaire effecten bewerkstelligen. Net zoals we in bepaalde settingen met woorden dingen kunnen doen, zo kunnen teksten de wereld een ander aanzien geven.

Hiernaast heeft Skinners onderscheid nog een andere kwaliteit: het attendeert ons op enkele belangrijke historiografische gevaren war mijn type van onderzoek aan blootstaat. Allereerst moet de taal-als-instrument metafoor ons er niet toe verleiden intenties van auteurs los te koppelen van het vocabulaire waarvan zij zich bedienen. Vocabulaires zijn niet voor een bepaald doel gemaakt, zoals een instrument dat well vaak is. Small had niet eerst het doel van de sociologie een discipline te maken en zocht daar vervolgens een 'geschikt' vocabulaire bij; Schmoller bezat niet eerst het oogmerk Weber te weerspreken en zocht vervolgens naar een taal om daarmee zijn doel te bereiken. De intellectuele doelen en oogmerken die in dit boek besproken zijn gaan kortom niet aan taalgebruik vooraf; doelen zoals het aanbrengen van een bepaalde demarcatie kunnen pas in een vocabulaire worden geformuleerd. Om vergissingen op dit punt te voorkomen heb ik met Nelson Goodman benadrukt dat vocabulaires altijd 'een versie van de wereld" constitueren.

Ook in een tweede opzicht gaat de gelijkenis tussen instrument en vocabulaire niet helemaal op: terwijl we bij instrumenten vaak gemakkelijk kunnen onderscheiden tussen functie en vorm, is dat onderscheid bij vocabulaires minder eenvoudig aan te brengen. Zeggen dat het vocabulaire van de sociale krachten voor Small, Thomas en Chapin verschillende functies vervulde, is geen goede samenvatting van mijn betoog in hoofdstuk VI. In dat geval wordt immers gesuggereerd dat het vocabulaire ondanks zijn verandering van (pragmatische) functie toch qua (semantische) vorm gelijk bleef, terwijl ik juist heb willen laten zien hoe de semantische betekenisrelaties en de pragmatische betekenis van dit vocabulaire samenhangen en ook tegelijk veranderen.

Door aandacht te besteden aan deze onderlinge afhankelijkheid van pragmatiek en semantiek kan worden voorkomen dat we vocabulaires reïficeren: een taal is geen stabiel 
gegeven dat we slechts kunnen aanwenden, taal verandert in ons gebruik ervan. Hier ligt ook de reden waarom ik (meer dan Kuhn) heb onderscheiden tussen vocabulaire en terminologie. Niet altijd wijst een nieuw taalgebruik namelijk op een verandering in de functie van een vocabulaire; wamneer dat laatste niet het geval is, spreek ik van een verandering in terminologie. In hoofdstuk VI is een illustratie van dit verschil te vinden. De Amerikaanse socioloog Ellwood vervangt het begrip associatie' door 'groep", maar de functie en (dus) de betekenis van beide termen zijn dezelfde, zo bleek. Terwijl bij Thomas het gebruik van het begrip 'groep" wel op een verandering in vocabulaire duidt, is daarvan bij Ellwood geen sprake.

Vocabulaires zijn noch afgesloten eenheden noch statische entiteiten. Niet alleen overlappen ze elkaar, ook veranderen ze in gebruik. Sommige elementen worden na korte tijd reeds vervangen, andere kunnen decennia lang blijven bestaan. Door de ontwikkeling van een taal niet los te koppelen van de manier waarop haar gebruikers die taal aanwenden, minimaliseren we niet alleen het genoemde gevaar van reifficatie. Langs die weg kan tevens worden verdisconteerd dat, bij voorbeeld, Spencer niet in cen totaal andere wereld leeft dan Chapin, of dat Small en Weber niet in een total andere wereld leven dan wij. Nog altijd zoeken sommige filosofen en sociologen naar een algemene evolutietheorie, nog altijd geloven sommige sociologen in het bestaan van universeel menselijke motieven of belangen, nog altijd staat de relatie tussen waarden en feiten ter discussie, nog altijd bestaat er verschil van mening over de taak van sociologie.

Op grond van het bestaan van zulke constanten* menen sommigen dat we bij historisch wetenschapsonderzoek het begrip vocabulaire' maar beter ter zijde kunnen schuiven. Het gebruik daarvan zou van de historicus te veel een 'historisi' maken, dat wil zeggen: hij zou slechts oog hebben voor lokale variaties en globale ontwikkelingen buiten beschouwing laten. De angst voor de fout om vocabulaires als autonome en afgesloten eenheden op te vatten, kan er echter toe leiden dat men de omgekeerde fout maakt: niet de taal, maar de elementen daaruit worden gereificeerd. Dat gebeurt wanneer men op grond van de observatie dat in het sociologisch taalgebruik bepaalde elementen gedurig terugkeren, concludeert dat die elementen zelf onveranderlijk blijven. Dit boek laat zich lezen als een weerlegging van deze conclusie. Door de activiteiten van Sanborn, Spencer, Ward, Chapin, Weber of Scheler in de context van een vocabulaire te plaatsen krijgen we oog voor het feit dat de betekenis van begrippen, de aard van intellectuele problemen en de inzet van intellectuele discussies niet decennia lang onveranderd blijven. Wij spreken niet meer in Smalls taal over universele motieven en we spreken ook niet meer in Webers taal over het waardevrijheidsprobleem. De dynamiek van intellectuele tradities is pas te reconstrueren, wanneer we, zoals Skinner zegt, de onderlinge samenhang tussen veranderende conventies en intenties onderzoeken.

Juist in het expliciteren van die samenhang bewijst zich de waarde van de taal-alsinstrument metafoor, ook al kunnen we een vocabulaire niet in alle opzichten met een instumentarium vergelijken. De metafoor wijst ons er namelijk op dat historische veranderingen gepaard gaan met transformaties in het gebriik van taal. Terwijl Spencer met zijn evolutietheorie een nieuwe moraal wou ontwikkelen, verbinden latere filosofen en sociologen zo'n theorie met andere doelen; terwijl Webers waardevrijheidsthese er voor een belangrijk deel toe dient de verwetenschappelijking van de politiek te voorkomen, raakt dat oogmerk bij latere sociale wetenschappers op de achtergrond. In zulke gevallen 
verandert met het gebruik van taal ook haar betekenis, zo luidt de voor intellectuele historici belangrijke strekking van de wittgensteiniaanse taaltheorie.

\section{Praktijken}

Behalve teksten of uitspraken kunnen ook onderscheidingen een pointe bezitten. Zo zijn onderscheidingen als tussen cognitieve en sociale of tussen interne en externe factoren door wetenschapssociologen geïntroduceerd met de intentie wetenschappelijke ontwikkelingen in hun maatschappelijke context te plaatsen of daaruit zelfs te verklaren. ${ }^{8}$ In dit boek spelen deze traditionele wetenschapssociologische onderscheidingen geen prominente rol. Dat hangt samen met opmerkingen die zoèven zijn gemaakt. Wanneer de taal waarin wij over de wereld spreken geen neutraal medium is, maar altijd een versie van de wereld constitueert, dan verschijnen namelijk ook dergelijke onderscheidingen in een nieuw licht. Ze liggen niet ten grondslag aan vocabulaires en gaan er ook niet logisch aan vooraf, maar worden altijd binnen de context van een vocabulaire gemaakt. Onderscheidingen als tussen het sociale en het cognitieve kunnen we (net als het onderscheid tussen wetenschap en niet-wetenschap) daarom beter niet als uitgangspunten voor historisch onderzoek kiezen; in plaats daarvan moet worden onderzocht hoe in vocabulaires zulke grenzen getrokken worden en hoe in die demarcatiearbeid een versie van de wereld wordt opgebouwd.

Hiermee is niet gezegd dat wetenschap zich autonoom een weg door de geschiedenis slingert. Niet alleen kunnen onderscheidingen of verbanden niet willekeurig worden aangebracht, demarcatiearbeid wordt bovendien altijd binnen een universitair en maatschappelijk decor verricht. Wanneer we echter cognitieve en sociale factoren niet als onafhankelijke grootheden kunnen opvoeren (om vervolgens tot de ontdekking te komen dat ze elkaar 'beïnvloeden'), dan dringt de vraag zich op hoe in mijn gevalsstudies dan wel 'de maatschappij' op het toneel verschijnt.

Voorzover 'de maatschappij' in dit boek op het toneel verschijnt, gebeurt dat - ten eerste - in de handelingen, keuzen en beslissingen van de onderzochte actoren. Daarbij heb ik met $Q$. Skinner aangenomen dat 'taaldaden' vaak niet cén strekking hebben, maar meerdere pointes bezitten. Nemen we als voorbeeld de in hoofdstuk III aangehaalde uitspraak van Ross: 'Een solide theorie van de sociale krachten dient de hoeksteen van de sociologie te vormen'. In deze uitspraak doet Ross verschillende dingen, zo bleek: hij definieert de academische identiteit van de sociologie, hij zet zich af tegen Sociale Wetenschap en hij haalt de banden aan tussen de sociologie en de zogenoemde progessieve beweging die zich inzet voor maatschappelijke en culturele hervormingen. De illocutionaire kracht van Ross' taaldaad laat zich dus niet eenduidig benoemen; naast cognitieve of intellectuele pointes kent ze ook minstens één cultuurpolitieke pointe. Dit boek verdedigt de stelling dat we 'sociologische' uitspraken of teksten niet ten volle begrijpen wanneer we aan die cultuurpolitieke dimensie voorbij gaan. Om een ander voorbeeld te noemen: we weten pas wat de "Beziehungslehre" van $L$. von Wiese betekende, wanneer we (ook) de cultuurpolitieke strekking van die leer achterhalen.

De taaldaden van intellectuelen of wetenschappers kennen meerdere pointes omdat ze zelden in één, enkelvoudige context staan. Een uitspraak of een tekst van een in dit boek besproken auteur is te situeren in de context van andere specifieke uitspraken of teksten van diezelfde auteur, maar ook van tijdgenoten, voorgangers of leden van een 
volgende generatie. Van al deze typen van auteurs abstraherend, kunnen we bovendien in contexten enige ordening aanbrengen door het werk van een auteur te situeren in de context van het vocabulaire waarvan hij zich bedient, in de context van (toenmalige) opvattingen over wetenschap, in de (toenmalige) universitaire context, in de (toenmalige) maatschappelijke context, enzovoort. Al deze contexten zijn ook opgevoerd, zij het niet steeds tegelijkertijd. Afhankelijk van de vraagstelling zijn per hoofdstuk de accenten anders gelegd.

'De maatschappij' is ook op een tweede manier ten tonele verschenen. In dit geval niet via de taaldaden van individuele auteurs, maar via het taalgebruik van collectieven. Ik heb namelijk niet alleen onderzocht in welke zin vocabulaires intellectueel handelen reguleren, in navolging van met name J.G.A. Pocock heb ik me tevens afgerraagd op welke manieren vocabulaires een gezagsorde legitimeren.

Een vocabulaire legt niet alleen de betekenis van begrippen, de aard van problemen en de procedures voor onderzoek vast; een vocabulaire geeft ook aan wie op welk gebied autoriteit bezit. Een verandering in taalgebruik impliceert dan ook altijd een verandering in de verdeling van gezag. Dit verband wordt door Kuhn reeds gellegd, maar is door Pocock meer expliciet naar voren gehaald. Als historicus van het politieke denken is hij er zich van bewust dat we een vocabulaire niet alleen als een theoretisch instrument moeten opvatten, maar ook als een politiek instrument. ${ }^{9}$

De Sociale Wetenschap die Sanborn c.s. gestalte geven, is niet alleen de uitdrukking van een religieus vertrouwen in feiten en statistiek, ze biedt tevens een nieuwe legitimatie voor de culturele autoriteit van de traditionele intellectuele standen. De taal waarin Small, Giddings en Ross sociologie bedrijven, belichaamt niet alleen hun vertrouwen in maatschappelijke vooruitgang, ze legitimeert ook een sociale orde waarin de sociologie zowel binnen als buiten de universiteit prominente taken vervult. De discussie tussen Schmoller en Weber is een confrontatie tussen twee vocabulaires, maar daarmee ook een botsing tussen twee concepties van de relaties tussen politiek, staat en wetenschap. De positivistische taal van $L$. von Wiese en zijn leerlingen geeft vorm aan hun empirischbeschrijvende sociologie, maar ze legitimeert ook de vestiging van een a-politieke sociale orde. De experimentele sociologie van Lundberg, Chapin en Dodd maakt niet alleen sociale krachten meetbaar, ze legimiteert tevens een nieuw type overheidspolitiek dat op sociale planning gericht is.

Tenslotte is 'de maatschappij' via een derde deur binnengetreden. Een vocabulaire bezit altijd een omgeving, zij het dat de grenzen tussen beide niet vooraf gegeven zijn. Door actoren in hun handelen te volgen, is duidelijk geworden dat de vorming van een vocabulaire ook de vorming van een buitenwereld inhoudt. Daarmee bedoel ik niet dat sociologen (of andere wetenschappers) de wereld naar hun hand kunnen zetten, maar wel dat de wijze waarop ze zich tot die wereld verhouden mede afhankelijk is van de (semantische) vorm en de (pragmatische) functie van hun taal. Omgekeerd spelen omgevingen een rol bij de vorming van die taal, maar welke dat zijn en welke rol zij spelen is een kwestie van (wederzijdse) percepties en verwachtingen.

Dit laatste punt kan door de structuur van mijn argument in hoofdstuk IV worden geillustreerd. Terwijl er enerzijds op gewezen is dat de Werturteilsstreit niet in een maatschappelijk vacuüm plaatsvindt, is anderzijds duidelijk gemaakt dat dit niet betekent dat de standpunten die Schmoller en Weber in dit debat innemen vanuit "de maatschap- 
pelijke context' kunnen worden verklaard. Op de vraag waarom dit laatste niet mogelijk is, heb ik echter niet het traditionele 'perspectivistische' antwoord gegeven dat beiden ontwikkelingen in de maatschappij anders percipiëren en interpreteren. Bij deze kenschets wordt over het hoofd gezien dat in de vocabulaires die Schmoller en Weber hanteren de grenzen tussen 'wetenschap' en 'maatschappij' anders getrokken worden.

Op ieder moment kent de sociologie meerdere omgevingen: ze staat in relatie tot andere wetenschappen, tot de universitaire structuur, tot culturele, maatschappelijke of politieke verhoudingen: Alhoewel de aard en de inhoud van deze relaties niet stabiel blijven, heb ik toch twee typen onderscheiden: relaties die in het teken staan van het aanbrengen van grenzen (zoals het demarqueren van de sociologie van andere sociale wetenschappen) en relaties die in het teken staan wan het slechten van grenzen (zoals het zoeken van aansluiting bij de volkshogeschoolbeweging in de republiek van Weimar). De omgevingen of contexten waarmee allianties worden gesmeed of waarin loyaliteiten worden gemobiliseerd heb ik praktijken genoemd. Praktijken zijn in dit boek omgevingen waarvan men zich niet demarqueert, maar waarop men zich oriënteert en waarin sociologische interventies een legitiem karakter kunnen krijgen.

In de context van zulke praktijken verliest demarcatiearbeid haar retorische structuur; ze biedt geen interpretaties, maar brengt eenvoudigweg onder woorden wat 'het geval is'. Temidden van de hervormers in Chicago heeft Smalls sociologie geen speculatief karakter, maar verwijzen zijn classificaties naar de realiteit. Binnen de muren van (sommige) Duitse volkshogescholen is Von Wieses 'Beziehungslehre' niet zomaar een theoretisch systeem, maar een afbeelding van de sociale wereld zoals ze werkelijk is. Door in deze zin te spreken over (sociale) praktijken wordt beklemtoond, dat sociologen niet 'futomatisch' een buitenwacht of een publiek bezitten. Sociologie is waar noch onmisbaar, maar kan in bepaalde contexten beide worden.

'De maatschappij" duikt in mijn betoog herhaaldelijk op, zo kunnen we concluderen. Maar ze doet dit niet in de rol van een verklarend begrip; daarom staat ze ook tussen aanhalingstekens. Sociologie krijgt betekenis in meerdere contexten en in hun handelen geven sociologen zelf weer betekenis aan een begrip als 'de maatschappij'. Daarnaast verschaffen praktijken een vocabulaire wetenschappelijke legitimiteit, terwijl omgekeerd een vocabulaire ook een praktijk kan legitimeren. Chapins experimentele sociologie verkrijgt legitimiteit door zich te verbinden met de in de jaren twintig opkomende praktijk van veldexperimenten in de Amerikaanse landbouw. Zijn de verschillen tussen het experimenteren met gewassen en het experimenteren met mensen eenmaal uitgevlakt, dan wordt het omgekeerd mogelijk om met Chapins sociologie allerlei activiteiten op het gebied van sociale planning te legitimeren. Aldus wordt niet gesproken over causale relaties tussen factoren of instituties, maar wordt de geschiedenis van de sociologie geanalyseerd in termen van taaldaden, symbolische interacties en legitimaties. 


\section{Naar een theorie van disciplines}

Hierboven is de methodologie van mijn onderzoek aan de hand van drie begrippen geëxpliciteerd: demarcatiearbeid, vocabulaire en praktijk. Deze begrippen zijn afzonderlijk besproken, maar krijgen pas in onderlinge samenhang betekenis. Over de betekenisrelaties tussen deze drie begrippen is al iets gezegd. Toch wil ik er nog nader over uitweiden, omdat langs die weg de contouren van een theorie van disciplines zichtbaar kunnen worden.

Op de weg van methodologie naar theorie onderscheid ik drie haltes. Eerst bespreek ik de synchrone relaties tussen de genoemde begrippen (de statica) en vervolgens hun diachrone relaties (de dynamica). De theorie krijgt tenslotte contouren in een vergelijking tussen intellectuele tradities en wetenschappelijke disciplines. Om niet alles tegelijk overhoop te halen, differentieer ik tot aan deze derde halte niet tussen beide, maar ga er vooralsnog van uit dat we een discipline kunnen opvatten als een traditie.

Wanneer de contouren van de theorie zijn geschetst, wachten nog twee vraagstukken op behandeling. In hoeverre stelt deze theorie ons in staat licht te werpen op de in dit boek aan de orde gestelde problemen van identiteilt, continuïteït, legitimiteit en autoriteit? En in hoeverre maakt deze theorie het mogelijk vergelijkend onderzoek te doen naar de geschiedenis van disciplines? Is er, anders gezegd, alleen binnen de context van mijn gevalstudies mee te werken of heeft de theorie meer potentie?

\section{De formele relaties tussen drie begrippen}

Op grond van de betekenis die ik aan de begrippen demarcatiearbeid, vocabulaire en praktijk gegeven heb, kunnen in formele zin hun onderlinge relaties allereerst synchroon worden benoemd. De volgende figuur brengt ze in kaart.

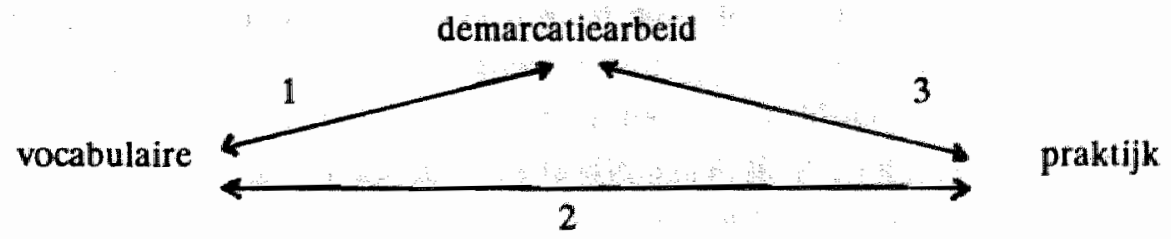

Demarcatie vindt plaats in een vocabulaire, terwijl omgekeerd een vocabulaire in die arbeid gestalte krijgt (1). Vocabulaires legitimeren praktijken en omgekeerd legitimeren praktijken vocabulaires (2). Het afbakenen van een veld of object van onderzoek maakt toegang tot een praktijk mogelijk, terwijl omgekeerd praktijken het mogelijk maken dat afbakeningen en classificaties een stabiel en reëel karakter krijgen (3).

Tegen de achtergrond van deze formele verbanden kunnen we een aantal observaties doen. Allereerst wijzen ze ons op de samenhang tussen sociale en cognitieve distincties. Het afbakenen van een veld beïnvloedt niet alleen de sociale verhoudingen tussen wetenschapsmensen, maar verandert ook de cognitieve relaties tussen hun theorieen. Bovendien wordt duidelijk dat praktijken niet alleen met behulp van sociale termen als 'institutie' of 'organisatie" te benoemen zijn, ze onderscheiden zich ook door cognitieve conventies.

In de tweede plaats krijgen we oog voor het feit dat het creẻren van cog- 
nitieve/sociale distincties op zijn beurt nauw samenhangt met het maken van bondgenootschappen. Scheiden doet verbinden. Schmollers onderscheid tussen subjectieve en objectieve waarden en de daarmee verbonden tweedeling tussen partijdige en onpartijdige wetenschap maken het mogelijk een alliantie te vormen met de overheidsbureaucratie. Chapins pogingen aansluiting te vinden bij agrarische overheidsprograma's kunnen niet los worden gezien van de onderscheidingen die hij probeert aan te brengen tussen persoonlijke en onpersoonlijke krachten en tussen normatieve en niet-normatieve vormen van sociologiebeoefening.

Ten derde kan worden verdisconteerd dat de handelingsruimte door intellectuele conventies wordt ingeperkt. Binnen de context van een bepaald vocabulaire liggen sommige afbakeningen meer voor de hand dan andere en zijn ook sommige allianties beter aan te brengen dan andere. Spencers synthetische filosofie impliceert een opvatting over wetenschap die haar doet onderscheiden van Sociale Wetenschap, maar of van dit onderscheid veel werk wordt gemaakt is een empirische kwestie: Spencers filosofie dwingt niemand Sociale Wetenschap te veroordelen. Binnen het kader van de taal van de sociale krachten is het niet verbazingwekkend dat Small c.s. zich oriënteren op publieke educatie. Dat neemt echter niet weg dat een dergelijk verband niet vanzelf ontstaat; het dient nog wel te wordlen aangebracht.

Onderzoek naar de synchrone relaties tussen demarcatie, vocabulaires en praktijken leert ons echter nog weinig over de historische ontwikkeling van intellectuele tradities en disciplines. Om de dynamica van bij voorbeeld de sociologische discipline enigszins te kunnen ontrafelen, is het ook nodig een blik te werpen op de diachrone relaties tussen datgene waar de genoemde begrippen naar refereren.

De dynamica van tradities en disciplines

Op grond van wat eerder is gezegd, zijn twee mogelijkheden om de dynamica van intellectuele tradities te conceptualiseren bij voorbaat uitgesloten. Tradities of disciplines vat ik om te beginnen niet op als in het verleden aanwijsbare entiteiten, omdat die conceptualisering bijna altijd een finalistische verklaringsstrategie impliceert. Dat wil zeggen: aan een discipline wordt bij voorbaat een identiteit toegekend, en daarmee uit het verleden gelicht. Op grond van die afbakening verschijnt een discipline snel als een 'ding' waarvan de groei moet worden verklaard. En is het probleem eenmaal in die termen gesteld, dan is de historicus geneigd om op zoek te gaan naar een interne logica of dynamiek ter verklaring van die groei. Historische variaties in de ontwikkeling van een discipline worden dan vervolgens verklaard in termen van 'weerstanden" en voorwaarden', oftewel in termen van gunstige of ongunstige externe condities die hun stempel drukken op de concrete historische verschijningsvorm van een traditie. Al dan niet bewust wordt zo een aristotelisch-thomistisch onderscheid op de geschiedenis geprojecteerd: een traditie kent naast essentiële eigenschappen (die de kern van haar identiteit uitmaken) accidentele eigenschappen (die maken dat ze in een bepaalde context een bepaalde vorm aanneemt).

Tradities of disciplines begrijp ik bovendien niet als 'bovenbouw'-verschijnselen, als een uitdrukking van 'de maatschappelijke verhoudingen". Een dergelijke conceptualisering miskent het perlocutionaire effect van teksten; ze stoelt dan ook op de door mij verworpen taal-als-medium metafoor. De pointe van dit type van contextualisme is 
immers dat we van disciplines kunnen vaststellen in hoeverre ze de werkelijkheid vertekenen, hetgeen veronderstelt dat we 'ideeên' naast 'de werkelijkheid' kunnen leggen. Wat 'werkelijk' is, kan echter niet buiten een vocabulaire om worden vastgesteld.

Om verder te komen dan de nietszeggende tussenweg van de 'dialectische wisselwerking* van discipline en omgeving ga ik - in het verlengde van eerdere opmerkingen over taal en taalgebruik - uit van een nominalistische definitie van disciplines. Daarmee bedoel ik: ze bestaan niet onafhankelijk van hun gebruik, maar alleen in het handelen van actoren. Ze kenmerken zich door (veranderende) vocabulaires waarin bepaalde uitspraken kunnen worden gedaan en andere niet, waarin probleemsituaties worden benoemd en regels voor hun oplossingen worden geformuleerd. Op grond van dit uitgangspunt kunnen we de dynamica van disciplines in de volgende elementen ontleden. ${ }^{10}$

1. Vocabulaires veranderen door variaties in hun gebruik, waarbij we kunnen onderscheiden tussen conventionele en innovatieve veranderingen. Terwijl er in het eerste geval alleen sprake is van terminologische vernieuwingen, treden er in het tweede geval veranderingen op in de vorm én functie van vocabulaires, dat wil zeggen: naast de semantische relatie tussen begrippen verandert ook de pragmatische betekenis van begrippen - de pointe van hun gebruik gaat verschillen en daarmee ontstaan nieuwe mogelijkheden voor het bewerkstelligen van perlocutionaire effecten. Op grond van dit criterium kunnen we bij voorbeeld zeggen dat zowel Thomas en Chapin innovaties aanbrengen in het progressief-evolutionair vocabulaire. $\mathrm{Ze}$ geven het begrip sociale kracht een andere betekenis dan Small en met hun uitspraken over sociale krachten doen ze ook andere dingen dan hij.

2. Het conventionele gebruik van een vocabulaire legitimeert de orde binnen de praktijk of praktijken waarmee het verbonden 1 s. Het conventionele gebruik dat Herkner makt van het mede door Schmoller vorm gegeven vocabulaire, rechtvaardigt de bestaande sociale orde waarin leden van de Verein fur Sozialpolitik een stempel drukken op de sociaal-economische politiek. Ellwoods conventionele gebruik van het progessiefevolutionair vocabulaire rechtvaardigt de bestaande praktijk van publieke volksopvoeding.

3. Innovatief taalgebruik komt meestal tot stand door het aanwenden van begrippen, methoden, technieken of stijlen van redeneren uit andere vocabulaires. 11 Spencer geeft het begrip 'energie' een nieuwe betekenis door het uilt de fysica naar de filosofie over te hevelen; Chapin geeft aan de experimentele methode een nieuwe inhoud door statistische methoden en technieken uit de agrarische wetenschap naar de sociologie te transporteren.

4. Innovatief taalgebruik wordt gestimuleerd door het ontstaan van kritiek op bestaande praktijken, door de wens zich te orienteren op andere praktijken of nieuwe praktijken te creëren. Veranderingen in vocabulaires maken dit soort wendingen acceptabel. Weber brengt veranderingen aan in het neo-kantiaanse vocabulaire die het mogelijk maken een strikte scheiding van wetenschap en staat rationeel te rechtvaardigen. Thomas (en Park) veranderen het progressief-evolutionair vocabulaire en legitimeren langs die weg (nieuwe) vormen van toegepast sociaal-wetenschappelijk onderzoek. Chapin geeft het begrip 'experiment' een betekenis die hem in staat stelt de praktijk van de sociologie te verbreden. Al deze activiteiten, zo moet worden benadrukt, zijn steeds op te vatten als onderdelen van én proces - anders zouden we immers toch 
doeleinden loskoppelen van de omgang met vocabulaires. Bovendien moet worden bedacht dat onderzoek naar de legitimerende functie van taal niet zozeer een studie is van de motieven of intenties van auteurs, maar een studie naar de perlocutionaire effecten van hun taalgebruik.

5. Niet alle veranderingen in yocabulaire zijn succesvol, dat wil zeggen: alleen sommige innovaties slagen er in een conventioneel karakter te krijgen. Of zij daar in slagen is afhankelijk van de mate waarin ze worden ingebed in reeds bestaande of nieuwe praktijken. Hoe dit gebeurt is afhankelijk van contingente factoren, maar we kunnen inmiddels wel aangeven wat zo'n inbedding inhoudt. Vernieuwingen in vocabulaires kunnen een conventioneel karakter krijgen wanneer ze hun oorspronkelijk vaak metaforische karakter verliezen en een verwijzend karakter verwerven. Zo moet in Amerika bij voorbeeld het begrip "kracht" van een natuurkundige metafoor veranderen in een begrip dat rechtstreeks naar sociale verschijnselen verwijst. Maar dat kan alleen wanneer er een praktijk voorhanden is waarin de uitspraken die in die vernieuwende taal worden gedaan op hun waarheid kunnen worden getoetst. Op dit laatste komt het aan. Want het is niet zo dat zulke praktijken altijd kant en klaar op wetenschapsbeoefenaren liggen te wachten. Soms moeten zij ze eerst zelf nog helemaal maken, zoals in het geval van Boyle. De uitspraken die hij op grond van experimenten met zijn luchtpomp deed, hadden niet van nature een verwijzend karakter, maar kregen die pas binnen een geheel nieuwe experimentele praktijk die Boyle tegelijkertijd vorm gaf. ${ }^{12}$ In andere gevallen kunnen wetenschapsbeoefenaren volstaan met het zich oriënteren op bestaande praktijken. In dit boek vinden we alleen voorbeelden van het laatste type, al moet daar dadelijk aan worden toegevoegd dat het hier niet een absoluut onderscheid betreft maar een verschil in accent. Want de oriëntatie op een bestaande praktijk, opdat de grenzen met een vocabulaire kunnen worden geslecht, leidt gewoonlijk ook tot een verandering van die praktijk. Ze moet als het ware passend worden gemaakt. ${ }^{13}$ Zo was de volksopvoeding niet van nature een setting waarin Wieses sociologie een verwijzend karakter had en op grond daarvan tot richtsnoer voor pedagogisch handelen kon worden gemaakt. Daar was een zekere modellering van die praktijk voor nodig. Zo lag ook voor de taal van Chapin niet eenvoudigweg een praktische inbedding klaar. De reeds bestaande praktijk van de landbouwexperimenten moest ondermeer met retorische middelen eerst worden gemodificeerd, opdat sociologische en agrarische veldexperimenten tot variaties van eén en dezelfde vorm van onderzoek konden worden gepresenteerd. Pas binnen die vernieuwde praktijk verwezen Chapins sociale krachten naar 'de realiteit'.

Rondom dit laatste punt kunnen snel misverstanden rijzen. Ik betoog niet dat alle uitspraken die bij voorbeeld Chapin doet binnen de gemodificeerde landbouwpraktijk waar zijn en daarbuiten onwaar. Een praktijk maakt uitspraken niet waar. Het voorhanden zijn van een passende praktijk zorgt er niet voor dat uitspraken waar worden, maar makt dat in die setting eenduidig kan worden vastgesteld of uitspraken waar danwel onwaar zijn. Chapins sociologie bezit binnen de landbouwwereld van sociale en biologische veldexperimenten het karakter van wat Kuhn 'normale wetenschap' noemt. Hetgeen niet meer zeggen wil dat de betekenis en het gebruik van Chapins begrippen en procedures in die context niet ter discussie staan.

En passant hebben we hiermee de taal-als-medium metafoor in onze theorie geïncorpereerd. Taal is weliswaar geen medium, maar neemt onder een speciale conditie wel die 
gestalte aan; in het geval namelijk wanneer we er in slagen een vocabulaire in een praktijk in te bedden. Het mediumkarakter van taal is kortom een effect van de afstemming van taal en praktijk.

\section{Tradities en disciplines}

Tot nog toe heb ik wetenschappelijke disciplines behandeld alsof het intellectuele tradities zijn. Maar is deze veronderstelling gerechtvaardigd? Onder een traditie verstaan we gewoonlijk immers iets anders. 'Traditie' is een breder begrip: een traditie hoeft niet de vorm aan te nemen van een discipline en is zeker niet altijd een wetenschappelijke discipline. Bovendien is er ook weinig aanleiding, zo lijkt het, om beide begrippen door elkaar te gaan gebruiken. We ontnemen ons dan de mogelijkheid om bij voorbeeld te onderscheiden tussen de sociologie als traditie en de sociologie als discipline. Dit alles neemt echter niet weg dat het onderscheid een beter begrip van de ontwikkeling van wetenschap ook in de weg kan staan. Een voorbeeld daarvan is in hoofdstuk VI gegeven: Toulmin definieert het begrip 'discipline' zo strikt dat hij onder andere de sociologie af moet doen als een 'would be' discipline. Ook om andere redenen verdient het aanbeveling om met het onderscheid tussen 'traditie" en 'discipline' lets soortgelijks te doen als met het onderscheid tussen 'sociale' en 'cognitieve' factoren: ze zouden niet het primaire kader moeten vormen waarin een theorie over disciplines vervolgens ontwikkeld wordt, maar zulke onderscheidingen dienen omgekeerd pas binnen 20 'n theorie betekenis te krijgen. Laat me dit nader toelichten.

Toulmin begrijpt disciplines als een speciaal soort tradities. Buiten zijn theorie noemen we echter niet alleen de fysica of de chemie een discipline, maar duiden we ook de sociologie of de psychologie met dit begrip aan. In dit geval betekent 'discipline' zoiets als 'een traditie plus iets extra's'. Een discipline veronderstelt meestal een professionele organisatie; een discipline heeft een "sociale" kant - bij een discipline denken we ook aan carrierepatronen, intitiatierituelen, recruterings- en uitsluitingsmechanismen. Een discipline heeft ook een 'materięle' kant: tegelijk met bij voorbeeld de sociologie zijn er sociologische instituten en bibliotheken verschenen. Naast dit alles lijkt een discipline tevens in intellectuele zin 'meer' te omvatten dan een traditie, omdat we binnen één discipline meerdere vocabulaires en ook meerdere specialismen kunnen aantreffen.

Deze manier om disciplines van tradities af te bakenen, veronderstelt echter een nogal idealistische en monolitische definitie van tradities. Tradities als het liberalisme of het marxisme zijn, evenals disciplines, meer dan een stel denkbeelden. Ze bestaan evenzeer uit teksten die zich tot andere teksten verhouden, teksten waarmee men dingen wou doen en inderdaad ook deed. Tradities zijn allesbehalve louter werelden van ideeen'; ze kennen evenals disciplines hun 'sociale' en 'materiele" kanten. Het liberalisme bij voorbeeld kreeg vorm in partijen, in constituties, in wetten, regels en rituelen. Bovendien bezitten tradities net zo min als disciplines een uniform karakter. Ook tradities kennen variaties in vocabulaire, ook binnen tradities kunnen meerdere scholen en richtingen ontstaan.

De vraag naar de verschillen tussen intellectuele tradities en wetenschappelijke disciplines kent bij nader inzien geen algemeen antwoord. Dat houdt niet in dat we helemaal niet over verschillen kunnen spreken; we zullen het probleem alleen anders 
moeten benaderen. In plaats van ingesleten tweedelingen als tussen wetenschap en ideologie of tussen politieke tradities en wetenschappelijke disciplines als uitgangspunt te nemen, kunnen we zulke dichotomieën vooralsnog beter tussen haakjes zetten. Want daarmee creèren we de mogelijkheid overeenkomsten en verschillen tussen tradities en disciplines empirisch te onderzoeken.

We beschikken inmiddels over een heuristiek voor een dergelijk onderzoek. Om tradities of disciplines te kunnen typeren moeten we aandacht besteden aan het karakter van de demarcatiearbeid, de aard van het taalgebruik en de verhoudingen met praktijken. Dat houdt in het kort het volgende in.

Vergelijkend onderzoek naar tradities en disciplines zall om te beginnen een studie behelsen van de stijlen en doelen van demarcatiearbeid en ook van de resultaten van die arbeid. Hierbij moet worden bedacht dat tradities noch disciplines zich demarqueren; vragen als 'wat is sociologie' of 'wat is liberalisme' komen pas op binnen de context van de vorming of verandering van collectieven. Onderzoek naar de demarcatie van tradities of disciplines richt zich daarom op de vraag hoe in lokale contexten zulke collectieven ontstaan en hoe zij zich een eigen identiteit verwerven. Daarbij kan gekeken worden naar de plaats waar die identiteit vorm krijgt (in teksten, of ook in rituelen, instituties, constituties, technieken en apparaten?); naar hoe die identiteit vorm krijgt (met retorische middelen, of ook met economische of politieke middelen?); en tenslotte naar de aard van die identiteit (presenteert een collectief zich als een wetenschap, een professie, een partij of een beweging?).

Vergelijkend onderzoek naar tradities en disciplines omvat in de tweede plaats een ondenoek naar verschillen in vocabulaires. Naast de studie van semantische en pragmatische verschillen, dienen we ons ook af te vragen hoe bij historisch wisselende actoren en collectieven de continulteit van een traditie of discipline wordt gewaarborgd. Zonder enigerlei vorm van continuiteit kan immers van een traditie of discipline geen sprake zijn. In dit verband rijzen vragen als: in hoeverre wordt een traditie of discipline gedragen door één vocabulaire; en: wat creẻert continuïteit - verhalen, gebruiken, technieken, apparaten?

Tenslotte dient te worden onderzocht in welke praktijken vocabulaires zijn ingebed, op welke manier dat gebeurt en hoe beide zich tot elkaar verhouden. Via dit onderzoek krijgen we een antwoord op de vraag naar de legitimiteit van tradities en disciplines en kunnen eveneens de omvang en de aard van hun culturele autoriteit worden getraceerd. Verschillen op dit vlak hangen ondermeer samen met het al dan niet 'uitwendige' karakter van de relatie tussen taal en praktijk: verschaft een vocabulaire ons alleen een herbeschrijving van één of meer reeds bestaande praktijken, of constitueert het ze ook zelf nieuwe praktijken? Terwijl bij voorbeeld Boyle (tezamen met andere leden van de Royal Society) een geheel nieuwe omgang met de natuur introduceerde, kunnen we niet zeggen dat de praktijk van de volksopvoeding of de praktijk van de sociale planning in dezelfde zin door sociologen in het leven geroepen zijn. In dit opzicht vertoont de liberale traditie meer overeenkomsten met de experimentele natuurkunde dan met de sociologie: de praktijk van de rechtstaat ging tenslotte ook niet aan het liberalisme vooraf. 
Dit alles is niet meer dan een ruw ontwerp van een wetenschapstheoretisch en ideeënhistorisch onderzoeksprogramma. Maar het voldoet als decor waarin de resultaten van mijn gevalstudies samenhang en betekenis kunnen krijgen. Door mijn resultaten in de context van dit programma te plaatsen wordt bovendien duidelijk hoe we sociologie met andere tradities/disciplines kunnen vergelijken. Het heeft weinig zin om naar verschillen en overeenkomsten tussen de sociologie en andere disciplines te vragen, wanneer we niet weten waar we die moeten zoeken.14 Weten we dat wel, dan rest uiteraard nog de empirische kwestie waarin - op de plaatsen die mijn theorie aanwijst de sociologie zich van andere disciplines onderscheidt. Een opstap voor zo'n vergelijking biedt een nadere beschouwing van de wijze waarop de in dit boek optredende actoren zijn omgegaan met wat ik heb aangeduid als de problemen van identiteit, continuitteit, legitimiteit en autoriteit. Deze bespreking leidt me tevens naar een nog nitet aangeroerd vraagstuk, namelijk: wat is eigenlijk de verhouding tussen de interpretaties die de leden van een traditie/discipline aan hun activiteiten geven en mijn theoretische tweede-ordeinterpretaties daarvan?

\section{Problemen van disciplinevorming: een terugblik}

Onderzoek naar wetenschap is tegenwoordig vooral onderzoek naar de cognitieve groei en de institutionele dynamica van wetenschap. Binnen dat kader wordt aan disciplinaire grenzen weinig gewicht toegekend. Wetenschap ontwikkelt zich immers vaak door inzichten uit andere disciplines of tradities in te zetten binnen het eigen vakgebied. Via de transportweg van de metafoor staan disciplinaire vocabulaires tenslotte in open verbinding met elkaar. Omgekeerd kunnen wetenschappers lid zijn van ến en dezelfde discipline en toch hun werkzaamheden onafhankelijk van elkaar verrichten. Wetenschapsfilosofen en wetenschapssociologen bestuderen daarom primair de lotgevallen van onderzoeksprogramma"s en wetenschappelijke gemeenschappen.

Dit boek is geen onderzoek naar de groei van kennis of de institutionele ontwikkeling van wetenschap. De settingen waarin sociologen hun onderzoek verrichtten, zjjn niet gedetailleerd in kaart gebracht en ook is het constructieproces van sociologische feiten niet stap voor stap beschreven. In plaats daarvan is mijn aandacht uitgegaan naar de manier waarop sociologen hun activiteiten gewicht en betekenis probeerden te geven. En voor onderzoek naar die betekenisgeving is het begrip 'discipline' juist wel een trefwoord.

\section{Identiteit}

In de loop van de $19 \mathrm{e}$ eeuw worden disciplines steeds meer belangrijke referentiepunten voor het toekennen van betekenis aan wetenschappelijke kennis en aan wetenschappelijk handelen. Door die genese van een disciplinaire orde wordt de 'great chain of being" verbroken, zoals in hoofdstuk II is uitgelegd. Als gevolg van deze ontwikkeling krijgt ook de vraag wat is sociologie?' een andere betekenis. Het stellen van deze vraag komt niet louter op omdat nu eenmal aangegeven moet worden waarmee men precies bezig is, zoals dat nog bij Comte of Spencer overwegend het geval was. Nee, zonder een antwoord op die vraag weet de vragensteller langzamerhand ook niet meer wie hij is, ic. 
wat zijn plaats en functie binnen de intellectuele wereld is. Wanneer wetenschapsbeoefenaren zich niet meer in algemene zin "geleerde" of "filosoof kunnen noemen, dan worden zulke definitieproblemen tegelijkertijd identiteitsproblemen.

Disciplinevorming begint met deze probleemverschuiving, op het moment dat talloze malen talloze mensen zich om deze nieuwe reden gaan afvragen wat sociologie eigenlijk is Omdat zij niet allemaal hetzelfde antwoord formuleren, verschuift het probleem nogmaals. Gegeven de diversiteit aan antwoorden kunnen Small, Ross of Durkheim niet meer tevreden zijn met alleen een antwoord op de vraag waarom zij zichzelf "socioloog' noemen. Door wat ik in hoofdstuk 1 'de collectivisering van de waarheid' heb genoemd, wordt het nodig te bepalen wat "socioloog zijn" voor wie dan ook en waar dan ook betekent. Vanaf het moment dat het identiteitsprobleem deze 'universele' vorm aanneemt, wordt demarcatie belangrijk en komt demarcatiearbeid in het teken te staan van de vorming van een collectieve identiteit. Van een naam die iedereen voor eigen doelen kan aanwenden, wordt 'sociologie' nu een begrip waarover een groep het bezit opeist. Het woord krijgt waarde, want het gaat staan voor een verzameling eigenschappen die mensen als Small, Ross of Durkheim als leden van een disciplime herkenbaar maken en die daarmee aan hun werk bestaansrecht verschaffen.

In Duitsland krijgt sociologie niet alleen later een disciplinaire betekenis dan in de Verenigde Staten, socialle wetenschappers en sociologen verrichten in beide landen ook andere taaldaden. Het maakt verschil, zo bleek, of men de identiteit van de sociologie ontleent aan het feit/waarde-onderscheid, zoals in Duitsland, of aan het wezen/verschijning-onderscheid, zoals in Amerika. Naast zulke verschillen in taaldaden, heb ik ook meer structurele verschillen kunnen benoemen die relevant zijn voor de identiteit van "sociologie".

In de Verenigde Staten worden de grenzen van het vak in hoge mate vastgelegd door cến dominant vocabulaire. Tot in de eerste decennia van de 20 eeuw kunnen sociologen zich in dit progressief-evolutionair vocabulaire op een drietal praktijken oriénteren: de stedelijke praktijk van 'opbouwwerk' en bestuurshervorming, de landelijke praktijk van publieke educatie en de universitaire praktijk van 'burgersschapsvorming". Sociologen kunnen deze praktijken bovendien op een manier beschrijven die maakt dat de drie genoemde gebieden met elkaar verbonden raken. In de sociologische versie van de wereld gaat het in deze settingen steeds om de volwassenwording van de 'sociale geest'.

$\mathrm{Na}$ de eeuwwisseling zien we de Verenigde Staten differentiaties in het sociologische vocabulaire ontstaan. Demarcatiearbeid leidt tot verschillende vormen van afbakening en sociologie raakt op verschillende manieren met praktijken verbonden. De praktijken van publieke educatie, stedelijke sociale technologie en sociaal-experimenteren op het platteland zijn niet meer in termen van één vocabulaire te beschrijven en ook de relaties tussen taal en praktijk gaan variatie vertonen: terwijl Ellwood nog wil opvoeden, wil Thomas ingrijpen in de sociale omgeving van groepen en wil Chapin de geest van de groep langs experimentele weg verbeteren. In dit veranderingsproces wordt het progressief-evolutionair vocabulaire niet zondermeer terzijde geschoven, maar op meerdere manieren opnieuw gestructureerd. Omdat dit steeds gebeurt in termen van het definiëren en classificeren van sociale krachten, blijft een zekere mate van afstemming tussen de verschillende sociologische stromingen mogelijk. De sociologische taal wordt als het ware uitgerekt, wat ondermeer tot uitdrukking komt in de introductie van velerlei soorten 
sociale krachten. Zolang deze aanwas te presenteren is als een teken voor sociologische vooruitgang (em niet een teken van conceptuele verwarring wordt), blijft het ook mogelijk de identiteit van de sociologie te blijven benoemen in disciplinaire termen. Ondanks allerlei vormen van onderlinge rivaliteit laat 'sociologie', zo heb ik in hoofdstuk VI laten zien, zich beschrijven als een gecoördineerd collectief project. Een discipline als de sociologie wordt niet zozeer bijeengehouden door een gedeeld object of gedeelde problemen, technieken of methoden, maar door verhalen en legendes waarin $\mathrm{zo}^{\mathrm{\prime n}}$ ordening via een realistische of perspectivistische stijl van redeneren wordt aangebracht. Met het creerren van disciplinaire orde, zoals bij voorbeeld Small en Chapin doen, wordt dan ook tegelijkertijd het genre van de disciplinegeschiedenis in het leven geroepen.

In Duitsland wint dit genre later veld dan in de Verenigde Staten; sociologie krijgt er dan ook pas in de loop van de $20 \mathrm{e}$ eeuw een disciplinaire betekenis. Daarvoor verwijst 'sociologie' vooral naar een theoretisch perspectief binnen de historische geesteswetenschappen. Sociologie heeft in die context een zuiver academisch karakter; ze kenmerkt zich juist door het feit dat ze niet op praktijken is georiënteerd. Sociologie zou, in de woorden van Weber, de gedaante van een zuiver intellectuele "Arbeitsgemeinschaft' moeten aannemen. Dit alles verandert in de republiek van Weimar. Sociologie slaagt er in een disciplinair karakter te verwerven op grond van een cultuurpolitiek bondgenootschap van gebruikers van uiteenlopende vocabulaires. De kracht van dit netwerk wordt versterkt door de onderwijspolitieke steun die het mobiliseert en ook door de gelegenheid die het krijgt zich op een gezamenlijke praktijk te kunnen orienteren: de volksopvoeding. In dit geval worden niet meerdere praktijken door een vocabulaire bestreken, maar houdt een praktijk verschillende vocabulaires bij elkaar. Zo verschaffen sociologen zich toch een herkenbare identiteit, ondanks hun weeltaligheid. De creatie van die identiteit gaat gepaard met een vorm van demarcatiearbeíd die er vooral op is gericht marxistische en socialistische vormen van sociologiebeoefening naar of over de rand van de discipline te schuiven.

Met deze interpretatie van disciplinevorming neem ik afstand van de manier waarop de betrokken actoren hun (taal)daden interpreteren. Het antwoord op de vraag wat is sociologie?' wordt in hun ogen bepaald door het karakter van 'de' sociale wereld of 'de' cultuur. De identiteit van het vak wordt zo gesitueerd in iets buiten henzelf, om haar vervolgens weer te ontlenen aan een beschrijving daarvan. Door hun activiteiten zo te typeren vat ik hun beschrijvingen van de wereld in feite op als interventies. ${ }^{15}$ Via hun taaldaden verandert de realiteit en ontstaan er nieuwe versies van de wereld. Dit is een kleine wending, maar ze is niet zonder gevolgen. Wie beschrijft plaatst zichzelf buiten beeld, abstraheert van contexten en zoekt naar objectiviteit; wie een beschrijving als cen interventie opvat, haalt auteurs en contexten juist binnen beeld. ${ }^{16}$

\section{Continuîteit}

Door de beschrijvingen van actoren als interventies op te vatten, verschijnt ook het probleem van continuitteit in een ander licht. Een onderdeel van het werk dat "mijn' actoren verrichten, is het beoordelen van het werk van vorige generaties op hun waarheidsgehalte. Small zegt: Spencer had een scherp oog voor sociale mechanismes, maar hij vergist zich in het ware karakter van die processen. Chapin zegt: Small heeft slechts 
aandacht voor persoonlijke krachten, hij ziet de onpersoonlijke krachten over het hoofd. Latere sociologen als Parsons en Merton zeggen: Small had het helemaal mis, hij makte het alleen maar mogelijk dat wetenschappers na hem de sociologie konden beoefenen. Ook in dit geval heb ik de actorinterpretaties een slag gedraaid door hun beschrijving van het verleden te beschouwen als interventies in het verleden; steeds wordt het herbeschreven. Continuïteit of discontinuitteit met het verleden is dan ook geen eigenschap van 'het' verleden, maar drukt onze relatie tot ons verleden uit.

Het effect van deze wending is opnieuw dat auteurs en hun contexten zelf in beeld verschijnen. Op grond daarvan ben ik in staat geweest een relatie te leggen tussen identiteitsproblemen en continufteitsproblemen. Tot het herbeschrijven van de wereld, de activiteit dus warin de eigen identiteit vorm krijgt, behoort het vertellen van verhalen over je voorgeschiedenis. Latere generaties sociologen geven niet alleen gestalte aan hun identiteit door opnieuw de verhouding tot hun onmiddellijke omgeving te bepalen. Hun veelal nieuwe definities van de situatie gaan gepaard met herformuleringen van de biografie van hun traditie. In de herformuleringen van deze biografie kunnen we een finalistisch patroon herkennen: steeds wordt het verleden als de voorgeschiedenis van de eigen (taal)daden beschreven. Continuitteit ontstaat, zo bezien, in het zich toeeigenen van het verleden, hetgeen ook verklaart waarom het verleden van een discipline geen neutraal gebied is: disciplines of stromingen daarbinnen wensen elk een eigen verleden te bezitten. Ze vatten het op als hun eigendom.

Disciplines creëren continuïteit, maar ook het omgekeerde geldt: in het aanbrengen van continuïteit met het verleden, in het selectief doorgeven van elementen door opeenvolgende generaties, ontstaan disciplines. $\mathrm{Zij}$ ontlenen hun sterkte, net als een draad, niet aan een essentie, eén vezel die door de hele lengte van de draad loopt, maar aan de omstandigheíd dat een groot aantal vezels elkaar overlappen. Hoe meer die vezels elkaar overlappen, hoe groter de cohesie van een discipline zal zijn. Ook op dit punt verschilt de vroege Amerikaanse sociologie van de Duitse sociologie. Vanaf Sanborns Sociale Wetenschap tot aan Chapins experimentele sociologie (maar ook later nog) blijven in Amerika thema's als het streven naar synthese en het ideaal van de harmonische gemeenschap in steeds andere bewoordingen terugkeren. Tussen het werk van Weber en dat van $L$. von Wiese bestaat dan ook een grotere cesuur dan tussen dat van Sanborn, Small, Ellwood, Thomas en Chapin. In de Verenigde Staten is continuïteit met het verleden ook beter aan te brengen dan in Duitsland, omdat dat in het eerste geval binnen de (verschuivende) grenzen van én vocabulaire gebeurt. Want al wordt continuiteit (of discontinuïteit) gecreserd, het betreft zeker geen willekeurige constructie. De mate waarin continuiteit met het verleden kan worden aangebracht, is afhankelijk van het al dan niet delen van een taal. En ook de wijze waarop ze wordt aangebracht, wordt door een vocabulaire gereguleerd.

\section{Legitimiteit en autoriteit}

Door de omgang met het verleden te interpreteren als het steeds opnieuw vormgeven daarvan, ben ik in staat geweest de problemen van identiteit en continuïteit te verbinden met het probleem van legitimiteit. Een belangrijke pointe van het herschikken van het verleden, zo bleek, is het rechtvaardigen van een mieuwe identiteit. Ik geef een voorbeeld. 
In Smalls versie van de geschiedenis van de sociologie begon het vak met onderzoek naar fysische sociale krachten en heeft het sinds kort meer oog gekregen voor de psychische sociale krachten. In Chapins versie begon de sociologie met de studie van persoonlijke krachten en heeft ze sinds kort meer aandacht gekregen voor de aard van onpersoonlijke krachten. In absolute zin is deze tweede versie noch beter noch breder dan die van Small, ze is dat alleen in relatieve zin, dat wil zeggen; binnen Chapins opvatting over wat sociologie (eigenlijk) is. Zien we dit in, dan wordt ook het omgekeerde verband duidelijk. In zijn herbeschrijving van de geschiedenis doet Chapin twee dingen: hij geeft de sociologie een andere identiteit - ze blijkt nu ook een experimentele wetenschap te kunnen zijn; en hij legitimeert deze verandering door continuïteit met het verleden aan te brengen - sociologen doen niet ineens heel iets anders, maar hun interesses verbreden zich.

Deze uitleg spoort opnieuw niet met wat 'mijn' actoren zelf menen wat ze doen. Voor hen is maar eén vraag echt van belang: in hoeverre mag sociologie wetenschap heten. Die kwestie is voor hen zo belangrijk omdat zij menen dat wetenschap haar eigen legitimatie in zich draagt. Valt sociologie eenmaal onder dat begrip, dan bezit zij automatisch legitimiteit.

Door ook nu weer hun beschrijvingen als interventies op te vatten, halen we twee zaken binnen beeld. We zien dat er spake is van verschillen en veranderingen in wat wetenschap betekent. En we zien dat de manieren waarop sociologen hun eigen werk legimiteren daarmee samenhangen. In hun vocabulaires incorporeren zij meer algemene beelden van wetenschap die de stijl en inhoud van hun demarcatiewerk mede reguleren. Op grond van verschillen in wat wetenschap in Duitsland en in de Verenigde Staten betekent, legitimeren Amerikaanse sociologen hun werk in positivistische termen en kiezen in Duitsland met name Weber, Mannheim en Scheler meer voor een geesteswetenschappelijk idioom. Naast deze globale verschillen zien we binnen beide landen ook verschuivingen in de wijze van legitimatie optreden. Volgens Ward, Giddings, Ross en Small stoelt het wetenschappelijke karakter van de sociologie vooral op haar "principles", op haar vermogen feiten te classificeren. Volgens Chapin daarentegen kan sociologie alleen maar wetenschap heten, wanneer ze zich houdt aan de methodologische regels van de experimentele wetenschap. In Duitsland zien we niet zo'n beweging van principes naar methoden, maar veeleer het omgekeerde. Weber legitimeert de sociologie primair met methodologische middelen, al staat zijn aanpak haaks op die van Chapin. Later, in de republiek van Weimar, schuiven methodologische vragen naar de achtergrond: Scheler en L von Wiese - maar ook Freyer, Vierkant en Oppenheimer stoelen het wetenschappelijk karakter van de sociologie weer meer op de kwaliteit van haar classificaties.

Met een antwoord op de vraag hoe men sociologie als wetenschap legitimeert, weten we nog niet hoe het vak die wetenschappelijke legitimiteit ook daadwerkelijk verwerft. Op grond van de hierboven geschetste theorie kunnen we verwachten dat die legitimiteit langs twee wegen verworven wordt. Allereerst door via demarcatiearbeid de eigen activiteiten te situeren in een netwerk van contexten. Aangegeven moet worden hoe het eigen werk zich van niet-wetenschappelijk werk onderscheidt, hoe het een traditie voortzet, hoe het zich verhoudt tot het werk dat andere sociologen verrichten en hoe het zich verhoudt tot werk binnen andere disciplines. Zowel in de Verenigde Staten als in 
Duitsland verwerft de sociologie zich via al deze demarcatiearbeid wel enige legitimiteit, maar stevig verankerd in de universiteil raakt ze daardoor niet. Wie wetenschappelijke legitimiteit alleen langs deze weg verwerven moet, loopt vaak spitsroeden en blijft leven met onzekerheden.

Maar legitimiteit kan ook langs een andere weg verworven worden, namelijk via het slechten van grenzen, via de vorming of het passend maken van praktijken. Onder een "praktijk" verstaan wetenschappers zelf gewoonlijk een reeds klaarliggend gebied waarin zij hun inzichten kunnen toepassen; in dit boek is een "praktijk" daarentegen opgevat als iets wat men niet eenvoudig aantreft: sociologen maken niet alleen kennis maar zetten zo mogelijk ook de wereld naar hun hand. Voor het verweven van wetenschappelijke legitimiteit is het beschikken over een praktijk in de eerste, traditionelle zin van het woord niet noodzakelijk, maar in de tweede zin wel. In de republiek van Weimar levert de sociologie geen toepasbare' kennis, maar verschaft ze zich via de oriëntatie op de volksopvoeding niettemin een wetenschappelijke legitimiteit. Ook in de Verenigde Staten verwerft de sociologie zich juist via haar banden met - in dit geval - meerdere praktijken een academische positie. Zonder de mogelijkheid om zich via deze tweede weg een legitieme plaats op het wetenschappelijk toneel te veroveren, zou de positie van het vak precair gebleven zijn. Want via demarcatiearbeid presenteert deze wetenschap zich weliswaar als onmisbaar, maar via haar banden met praktijken maakt ze zich onmisbaar.

Door niet aan te nemen dat sociologie op een vanzelfsprekende manier wetenschappelijke legitimiteit bezit, slechts betwist door obscurantisten en andere kwaadwilligen, kon ook van culturele autoriteit een probleem worden gemaakt. Cultureel gezag is niet iets wat wetenschap per definitie bezit, maar komt onder specifieke condities tot stand. Het cullturele gezag van een discipline is om te beginnen afhankelijk van haar banden met praktijken. Alleen via die weg kan culturele autoriteit worden opgebouwd. In hoeverre autoriteit verworven wordt, is echter niet uitsluitend afhankelijk van de mate waarin een discipline er in slaagt zich binnen een praktijk onmisbaar te maken. Culturelle autoriteit wordt in de tweede plaatst ontleend aan de mate waarin die praktijk met andere praktijken verweven is. In de republiek van Weimar nam het culturele gezag van de sociologie toe toen politici de volksopvoeding als een essentieel onderdeel van de natievorming begonnen te beschouwen. In de Verenigde Staten wint de sociologie aan gezag wanneer de praktijk van de sociale technologie met allerlei overheidsprogramma's verbonden raakt:

Nu alle vier problemen van disciplinevorming de revue zijn gepasseerd, blijft de vraag staan hoe de besproken actorinterpretaties zich tot mijn betoog verhouden. Bezitten de onderzochte sociologen een naïef zelfbeeld? Ben ik reflexiever dan zij? Deze vragen bieden geen goede ingang om de verhouding tussen hen en mij te benoemen, omdat we dan een belangrijke overeenkomst over het hoofd zien. Zoals zij in mijn ogen de wereld of het verleden niet beschrijven maar daarin interveniëren zo kan een criticus opmerken dat ik niet de geschiedenis van de vroege Amerikaanse en Duitse sociologie heb beschreven, maar haar opnieuw geordend heb.

Op grond van deze overeenkomst kan het onderscheid dat ik in het eerste hoofdstuk heb gemaakt tussen finalistische en niet-finalistische geschiedschrijving worden aangescherpt. Dit onderscheid verwijst niet naar de tegenstelling tussen subjectieve en 
objectieve geschiedschrijving of naar die tussen waardegeladen en waardevrije geschiedschrijving. Daarmee zouden we immers suggereren dat finalistische geschiedenis louter op interpretatie berust, terwijl niet-finalistische studies het verleden uitsluitend beschrijven. Maar dat is juist niet het geval: zulke studies leveren veeleer nieuwe interpretaties; ze ordenen het verleden anders dan voorheen.

Zoals iedere interpretatie die zich niet louter als een beschrijving wil voordoen, stoelt mijn betoog op expliciet gemaakte methodologische en theoretische veronderstellingen. Binnem dat kader krijgen de problemen van identiteit, continuïteit, legitimiteit en autoriteit ook pas de betekenis die ik er aan gegeven heb. Het zijn geen problemen die altijd al in de historische realiteit aanwezig waren, ook al hadden wetenschapsmensen daar nog geen weet van. Het zijn vraagstukken die door mij zijn opgeworpen en die een duidelijke stellingname verraden: de ontwikkeling van tradities en disciplines moet op (minstens) deze vier problemen worden onderzocht en dient met behulp van de begrippen demarcatiearbeid, vocabulaire en praktijk te worden geïnterpreteerd.

\section{Relevantie}

Disciplinegeschiedenis ontleent traditioneel haar rechtvaardiging aan het feit dat ze dienstbaar is aan de verdere ontwikkeling van een discipline. Een betere kennis van het verleden van een vak, komt de beoefening van dat vak ten goede. Heeft mijn programma van onderzoek niet het nadeel dat deze band tussen het verleden en het heden van een traditie of discipline wordt doorgesneden?

De door mij gekozen aanpak roept nog een tweede bezwaar op, dat als volgt kan worden samengevat. Wij beschikken over een aantal eenvoudige verklaringen voor thet onderscheid tussen sociaal-wetenschappelijke disciplines en natuurwetenschappelijke disciplines. Tussen beide bestaat een ontologisch verschil: de natuur interpreteeert zichzelf niet, maar mensen wel; tussen beide bestaat een kennistheoretisch verschil: terwijl natuurwetenschappelijke verkJaringen niet afhankelijk zijn van niet-wetenschappelijke interpretaties van de werkelijkheid, kunnen sociaal-wetenschappelijke verklaringen zich daarvan niet losmaken; en er bestaat tussen beide een methodologisch verschil: natuurwetenschappelijke variabelen zijn in experimentele settingen manipuleerbaar of in elk geval van elkaar te isoleren, hetgeen in de sociale wetenschappen niet of nauwelijks mogelijk is. Op grond van deze verschillen laat het onderscheid tussen bij voorbeeld de sociologie en de chemie zich gemakkelijk verklaren en is een nieuw onderzoeksprogramma overbodig.

Eén ding moet ik toegeven: mijn voorstellen hebben een ontmoedigend effect. De relatie tussen een discipline en haar geschiedenis blijkt veel complexer en ondoorzichtiger dan de beoefenaren van disciplinegeschiedenis vaak menen. Hell bedrijven van disciplinegeschiedenis is niet een kwestie van eenvoudig omkijken; de weg terug kent vele historiografische valkuilen. Ook de relaties tussen disciplines zijn veel minder eenvoudig en eenduidig dan de aanhangers van het legpuzzel- of het loketmodel van disciplines veronderstellen. Disciplines zijn in mijn versie van de wereld historische constructen; ze staan niet in een ontologisch, kennistheoretisch of methodologisch gegeven orde, die ordes zijn veeleer zelf het produkt van een contingent historisch proces van disciplinevorming. In dit opzicht kent mijn programma een duidelijke negatieve heuristiek: ze ontneemt ons de mogelijkheid onderscheidingen tussen tradities 
of disciplines af te leiden uit hun inherente eigenschappen. Het is eigenlijk een voorstel tot een verdere secularisering van ons wereldbeeld: pogingen de verschillen tussen disciplines, tussen academische standen en klassen zeg maar, te verklaren uit de structuur van de schepping, worden binnen mijn theoretisch kader geinterpreteerd als projecties, als legitimaties van historisch geconstrueerde vormen van intellectuele stratificatie.

Toch heeft mijn wijze van omgang met het verleden ook een opwekkende kant. Sociologen maken van demarcatie bij herhaling een probleem door zich af te vragen: wat is 'sociologie' en wat zijn haar taken? Op die vraag geeft dit boek geen antwoord, niet alleen omdat zijn empirische basis daarvoor te smal is, maar ook omdat er uitdrukkelijk een theoretisch en methodologisch 'faseverschil' is aangebracht tussen hun problemen en mijn problemen. Maar dit neemt niet weg dat het een opening biedt om aan bestaande discussies een nieuwe wending te geven.

Om te beginnen bepleit deze studie aan demarcatievraagstukken een andere status toe te kennen. $\mathrm{Ze}$ verwijzen niet naar grondslagenkwesties die los staan van de dagelijkse praktijk van sociologiebeoefening, maar naar problemen van beeldvorming en situering van die praktijk. Pogingen het formele of materièle object van de sociologie af te bakenen, zijn pogingen een collectieve identiteit te articulleren. Deze interventie verruimt de discussie in een aantal opzichten. $Z$ o hoeven we niet langer te zoeken naar contextvrije definities van het vak. Het is niet erg dat iedere afbakening stoelt op percepties van de buitenwereld of op exemplarische beelden en voorbeelden. Identiteit laat zich immers niet formuleren buiten contexten om; een identiteit vormt zich juist in interactie met omgevingen. De sociologie modelleren naar een natuurwetenschap (of naar welke andere traditie dan ook) is zo bezien op zichzelf niet verwerpelijk, het gaat er alleen om hoe we zulke keuzes rechtvaardigen. Dat zal niet langer kunnen in termen van wezensgelijkenissen of inherente overeenkomsten. Het zal moeten gebeuren in termen van met zo'n voorstel verbonden handelingsconsequenties. Waar brengt een bepaalde identiteit ons en waar niet? Door in deze termen over het vak te spreken is het ook niet erg meer dat de discussie een mengeling van descriptieve en evaluatieve elementen bevat. Want zodra we het zoeken naar een objectieve fundering voor de sociologie inruilen voor een discussie over haar historische situering kunnen bij voorbeeld wetenschapspolitieke argumenten openlijk worden geuit. $\mathrm{Ze}$ hoeven niet langer verhuld als ontologische, kennistheoretische of methodologische argumenten door het leven te gaan.

Ook andere disciplinaire problemen kunnen op grond van mijn studie een wat handzamer karakter krijgen. Door te beklemtonen dat de identiteitsvraag nooit in abstracto te beantwoorden is, benadrukken we dat er tussen disciplinaire binnenwerelden en de wereld daarbuiten een veelvoud van grenzen en betrekkingen bestaat. Zo verwijst demarcatie altijd naar meerdere afbakeningen ten opzichte van meerdere omgevingen. Door dat inzicht zullen we bij kwesties als 'hoe de autonomie van het vak te bewaken?" steeds vragen "autonomie ten opzichte waarvan?". Want het zich willen afbakenen van bepaalde maatschappelijke groeperingen hoeft helemaal niet te betekenen dat men ook culturele invloeden wenst uit te bannen. En autonomie ten opzichte van de economische wetenschap opeisen staat los van de vraag hoe de sociologie zich tot de rechtswetenschap dient te verhouden. Op grond van het aanbrengen van éen grens hoeft men 
kortom niet dadelijk tot het trekken van andere grenzen te besluiten.

In het verlengde van dit punt kunnen we nog twee andere opmerkingen maken. Hoe men zich tot een omgeving wil verhouden en hoe men zich instelt op nieuwe of veranderende omgevingen is mede afhankelijk van de mogelijkheden en beperkingen die een vocabulaire bezit. Veranderingen in demarcatiearbeid kunnen het daarom nodig maken het vocabulaire waarmee men werkt op onderdelen bij te stellen. Inzicht in deze relatie maakt het mogelijk verandering van demarcatie en van vocabulaire beter tegen elkaar af te wegen.

Zich onderscheiden van bepaalde omgevingen kan, bovendien, heel goed samengaan met het uitvlakken van grenzen elders, met het zich orienteren op en het passend maken van praktijken. Tegelijkertijd zien we in dat dit steeds een afweging behelst: zich verbinden met nieuwe praktijken brengt veelal ook veranderingen in de demarcatiearbeid en het vocabulaire met zich mee. Wanneer bij voorbeeld Chapin zijn aandacht verlegt van sociale opvoeding naar sociale technologie, impliceert dit andere demarcaties (zoals een toenadering tot de experimentele landbouwwetenschap) en een herschikking van het sociologische vocabulaire (zoals het anders classificeren van sociale krachten). We kunnen, waren we Chapins collega's, op alle drie niveaus Chapins daden beoordelen. Maar daarmee zijn onze mogelijkheden niet uitgeput: we zijn in staat zijn daden op die drie niveaus met elkaar in verbinding te brengen en tegen elkaar af te wegen. Ook al zouden we zijn wending naar een nieuwe praktijk op zichzelf niet problematisch vinden, dan nog kan de vraag worden gesteld: is de toenadering tot de landbouwwetenschap, of zijn de veranderingen op theoretisch vlak die ermee gepaard gaan, niet een te hoge prijs voor die praktische heroriëntatie? Op deze manier kunnen, ook vandaag de dag, innowaties op hun verschillende consequenties worden beoordeeld.

Alle genoemde voorbeelden maken duidelijk dat disciplinaire problemen steeds verwijzen naar afstemmingsproblemen die geen definitieve of optimale oplossing kennen. Een goede oplossing kan morgen al weer nieuwe problemen oproepen. Dat maakt de discussie complex maar niet per se ondoorzichtig, zeker wanneer we beseffen dat nietfinalistische geschiedschrijving hier juist behulpzaam kan zijn. Sociologen krijgen meer greep op de dynamica van hun vak wanneer zij beschikken over historische reconstructies van vroegere 'afstemmingen' tussen demarcatiearbeid, vocabulaires en praktijken.

De vorm van niet-finalistische geschiedschrijving die in dit boek is gepresenteerd, kan aan discussies over de identiteit van de sociologie niet alleen een nieuwe wending geven. Deze studie suggeert ook om zulke discussies in een bredere kring dan alleen in die van de sociologie te voeren. Wanneer het zo is dat een controverse over de identiteit van de sociologie ook steeds een discussie is over de vraag welke versie(s) van de (sociale) wereld onze voorkeur verdienen, dan is er geen reden het debat alleen door sociologen te laten voeren. Economen, psychologen, filosofen, literatoren of politici kunnen evenzeer meespreken. En wanneer zij dat doen, dan hoeft dit door sociologen niet te allen tijde gepercipieerd te worden als tekenen van bemoeizucht, geldingsdrang of rivaliteit. Zodra we ons realiseren dat identiteit uitsluitend in interactie met anderen vorm krijgt, beseffen we ook dat die ontwikkeling evenzeer andermans zorg is. Sociologie is te belangrijk om alleen aan sociologen over te laten. 
Noten behorende bij hoofdstuk VII

1. Zie King (1971) voor een fundamentele kritiek op de wetenschapssociologie van Merton.

2. Gieryn (1983).

3. Vgl. Mol (1988).

4. Vgl. Hacking (1982); Rorty (1991).

5. Zie Kuhn (1984).

6. Skinners bekendste methodologische opstellen zijn gebundeld in Tully (1988).

7. In Tully (1988): 54.

8. Zie voor deze achtergrond Nauta/De Vries (1979).

9. Vgl. Pocock (1971); Pocock (1985). Voor een vergelijkïng van de ideeën van Skinner en Pocock zie Janssen (1985). Janssen biedt tevens de critici van Pocock en Skinner van repliek. Deze discussie blijft hier buiten beschouwing.

10. Deze 'ontleding' is gedeeltelijk geênt op $\mathrm{Q}$. Skinner, Some problems in the analysis of political thought and action, in: Tully (1981).

11. Vgl. Goodman: 'Worldmaking (...) starts from worlds already on hand; the making is a remaking.' Goodman (1978): 6.

12. Zie Shapin/Schaffer (1985).

13. Dit 'passend maken' kan ook weer tot veranderingen in het vocabulaire leiden. Het is in dit opzicht te vergelijken met wat Goodman en Elgin 'fitting' hebben genoemd. Zie Goodman/Elgin (1988). Een interessante toepassing van dit idee geeft Pasveer (1992).

14. 'Theorieèn dienen ons (...) niet alleen verklaringen voor verschijnselen te verschaffen. Zij moeten ons ook de middelen aan de hand doen om die verschijnselen te beschrijven. Ook de zogenaamde beschrijvende studies vereisen het ontwikkelen van een theorie.' De Vries (1977): 142. In de terminologie van De Vries presenteer ik in deze paragraaf een beschrijvende theorie.

15. Vanuit een andere invalshoek onderscheidt Ankersmit tussen een beschrijving en een representatie van de wereld. Zie b.v. Ankersmit (1992). Om te benadrukken dat sociologen in hun teksten als het ware een nieuwe wereld creeren (in plaats van afbeeldingen van de bestaande te maken), kies ik voor een meer 'activistisch' begrip.

16. Vgl: Rorty (1990). 


\section{SUMMARY}

Traditional research on the history of sociology is characterized by a finalistic approach. Society is commonly presented as something like a natural phenomenon that had remained undiscovered until the nineteenth century. Moreover, this approach gives the impression that once certain intellectual and social requirements had been met, the discovery of society more or less automatically led to the development of a separate discipline. Chapter I challenges this traditional account of the development of sociology. By considering a few examples it is argued that a finalistic view, particularly if based on a jigsaw- or pigeonhole-model of disciplines, does not question the identity of a discipline, but rather takes it for granted. Within this framework there is no room for problems as to how sociology acquired its features and the ways in which it changed throughout the nineteenth and twentieth centuries. Again, certain elements of the view in question will lead to the present-day historian's presupposing a notion of historical continuity instead of questioning it. Thirdly, whoever does not make an issue of the identity and continuity of a discipline, will always assume its legitimate position as a scientific discipline without looking into the ways the members of this discipline came to acquire their legitimate position within certain fields. Finally, by ignoring the question as to how sociology managed to secure its legitimate position on the academic scene, one will leave aside the question as to the ways in which it aimed for cultural authority among other disciplines. These four problems traditional research on the origins of sociology has passed over are the main focus of the present work. At the same time, the present study on the identity of early American and German sociology is an enquiry into the continuity, legitimate position and authority connected with its history and status.

The finalistic approach to history not only ignores a number of disciplinary problems, but also helps to form disciplinary legends. For example, we have been led to believe that the first sociologists entered an empty stage, as if they were the first to ever make society the object of scientific enquiry. Chapier II corrects this view and discusses two forms of pre-disciplinary social science practised during the second half of the nineteenth century in the United States. In addition it presents a non-finalistic interpretation of the decline of pre-disciplinary scientific practices, explaining it instead as a period of transition indicating the development of new conventions regarding scientific forms of explanation.

Chapter III deals with the establishment and demarcation of sociology as an academic discipline in the United States. It focuses on three aspects of this development, viz. the ways in which sociologists, by establishing boundaries, created not only a social, but also a cognitive field of enquiry, the vocabulary they produced in their attempts to construe a sociological reality, and the social practices the new discipline became associated with. The first American sociologists present sociology as a separate science but do not 
consider it a specialism. Their views on the position of sociology are completely in line with their vocabulary that suggests a progressive evolutionary development, and have a cultural-political meaning. In their battles against scientific as well as social desintegration sociologists attempt to bring public opinion to a higher level.

In the United States the establishment of sociology had nothing to do with pleas for keeping science value-free. In Germany, on the other hand, the so-called debate concerning the value-free nature of science had its impact on the demarcation of sociology. The non-finalistic reconstruction of this debate in chapter IV enables one to see how the pleas for keeping science value-free amounted to a methodological strategy to separate the practice of social sciences from the older political sciences. Other than in the United States, the demarcation of sociology in Germany was less a matter of establishing a new discipline.

In the period after the first World War the practice of sociology in Germany and the United States begin to show certain similarities. In Germany, too, sociology is gradually transformed into a discipline. Moreover, like early American sociology, German sociology acquires a cultural-political significance. Nevertheless, important differences remain. Chapter V pays special attention to one of the main differences between the two traditions. While in the United States sociology is based on one vocabulary only, German sociologists use different linguistic styles to present their arguments. All the same, in the Republic of Weimar sociology does succeed in acquiring its own identity as a discipline, an identity that consists not in the sharing of one vocabulary, but of one practice. Almost all sociologists were active in the field of public education.

The previous chapters primarily focus on the way in which sociology became an established discipline. In chapter VI it is illustrated that the development of a discipline can also be reconstructed in a non-finalistic manner. If one considers what happened in the United States, it appears that the changes that took place in sociology in the period between 1905 and 1935 are not connected with any teleological process. Rather they should be characterized as a selective process of variation. For theoretical as well as practical reasons, the vocabulary suggesting a progressive evolutionary development is adjusted in various ways. The fact that American sociology breaks up into diverse schools and scientific communities does not, however, mean that it thereby loses its disciplinary identity. In the stories they relate to each other sociologists continue to present sociology as a collective and purposeful enterprise.

The history of science carried out in the present work is based on a number of methodological and philosophical assumptions that are discussed and assessed in the final chapter. In addition ideas are presented for a theoretical framework of the history of disciplines. Whoever intends to answer the problems brought up in the first chapter concerning the formation of disciplines should concentrate on the ways in which the members of the discipline in question establish the boundaries of their discipline (demarcation), the vocabularies they use and the (social) practices they focus on. 


\section{BIBLIOGRAFIE}

Ahlstrom, S.E. (1955), The Scottish Philosophy and American Theology, in: Church History 24: 257-72.

Alemann, H. von (1976), Leopold von Wiese und das Forschungsinstitut für Sozialwissenschaften in Köln 1919 bis 1934, in: Kölner Zeitschrift für Soziologie und Sozialpsychologie, 28: 649-673.

Allen, G. (1979), The Transformation of a Science: T.H. Morgan and the Emergence of a New American Biology, in: Oleson/Voss (1979).

Ankersmit, F.R. (1990), De navel van de geschiedenis. Over interpretatie, representatic en historische realiteit, Groningen.

Ankersmit, F. (1992), Retorica en geschiedschrijving, in: T.A.F. Kuipers (red.), Filosofen in Actie, Groningen.

Ankersmit, F., M.C. Doeser, A.K. Varga, (red.) (1990), Op Verhaal Komen. Over narrativiteit in de mens- en cultuurwetenschappen, Kampen.

Apel, KO. (1967), Der philosophische Hintergrund der Entstehung des Pragmatismus bei Charles Sanders Peirce, in: C.S. Peirce, Schriften I, Hrsg. K.O. Apel, Frankurt a.M..

Aron, R. (1935), La Sociologie Allemande Contemporaine, Paris.

ASSA (1866), Constitution, Adress, and List of Members of the American Association for the Promotion of Social Science, Boston.

Baker, KM. (1960), The early history of the term 'social science', in: Journal of the History of Ideas 20: 211-26.

Bannister, R.C. (1979), Social Darwinism. Science and Myth in Anglo-American Social Thought, Philadelphia.

Bannister, R.C. (1987), Sociology and Scientism. The American Quest for Objectivity 1880 . 1940, Chapel Hill/London.

Barnes, H.E. (ed.) (1948), An Introduction to the History of Sociology, Chicago.

Barth, P. (1921), Die Philosophie der Geschichte als Soziologie, Leipzig.

Becher, H.J. (1971), Georg Simmel. Grundlagen seiner Soziologie, Stuttgart.

Becher, T. (1981), Toward a Definition of Disciplinary Cultures, in: Studies in Higher Education 6: 109-22.

Beck, U. (1974), Objektivităt und Nornativität: Die Theorie-Praxis-Debatte in der modernen deutschen und amerikanischen Soziologie, Reinbek bei Hamburg. 
Becker, C.H. (1919), Gedanken zur Hochschulreform, gedeeltelijk herdrukt in: Kulturverwaltung der zwanziger Jahre, Alte Dokumente und neue Beitrdge, Stuttgart 1961.

Becker, C.H. (1925), Vom Wesen der deutschen Universitat, Leipzig.

Becker, H.S. (1967), Whose side are we on?, in: Social Problems 14: 239-248.

Ben-David, J., A. Zloczower (1962), Universities and Academic Systems in Modern Societies, in: Archives europeênnes de sociologie 3: 45-84.

Bentley, A (1908), The Process of Government, Chicago.

Berking, H. (1984), Masse und Geist. Studien zur Soziologie in der Weimarer Republik, Berlin.

Bernard, L.L. (1925), Scientific Method and Social Progress, in: AJS 31: 1-18.

Bernard, L.L. J. Bernard (1943), Origins of American Saciology: The Social Science Movement in the United States, New York.

Bevers, AM. (1982), Geometrie van de samenleving filosofie en sociologie in het werk van Georg Simmel, Deventer.

Bickel, C. (1991), Ferdinand Tönnies: Soziologie als skeptische Aufkläning zwischen Historismus und Rationalismus, Opladen.

Blackbourn, D., G. Eley (1984), The Peculiarities of German History. Bourgeois Society and Politics in Nineteenth-Century Germany, Oxford/New York.

Bledstein, B. (1976), The Culture of Professionalism: The Middle class and the Development of Higher Education in America, New York.

Boese, F. (1939), Geschichte des Vereins fur Sozialpolitik 1872-1932, Berlin.

Boon, L. (1989), Wetenschapstheorie en historisme, in: L. Boon en G. de Vries (1989).

Boon, L., G. de Vries (red.) (1989), Wetenschapstheorie: De empirische wending, Groningen.

Boon, L. e.a. (1991), Wetenschapsontwikkeling en kundes, in: Kennis en Methode 15: 150-163.

Bottomore, T., en R. Nisbet (eds.) (1978), A History of Sociological Analysis, New York.

Bourdieu, P. (1981), The Specificity of the Scientific Field, in: C.C. Lemert, French Sociology, New York.

Brecht, A, Political theory, Princeton 1959.

Brentano, L. (1911), Ueber Werturteile in der Volkswirtschaftslehre, in: Archiv für Sozialwissenschaft und Sozialpolitik 33: 695-714.

Bril, J.G.M. e.a. (1966), Socioloog, wat kom je doen?, Nijmegen/Utrecht. 
Brozek, J. (ed.) (1984), Explorations in the History of Psychology in the United States, Lewisburg.

Bruch, R. vom (1980), Wissenschaft, Politik und dffentiche Meinung. Gelehrtenpolitik in Wilhelminischen Deutschland, Husum.

Bruun, H.H. (1972), Science, values, and politics in Max Weber's methodology, Copenhagen.

Bryant, G.A. (1985), Positivism in Social Theory and Research, New York.

Bryson, G. (1931/32), The emergence of the social sciences from moral philosophy, in: The International Joumal of Ethics 42: 304-23.

Buck (ed.) (1965), Social Sciences at Harvard 1860-1920, Cambridge Mass.

Bulmer, M. (1984), The Chicago School of Sociology. Institutionalization, Diversity, and the Rise of Sociological Research, Chicago.

Bulmer, M. (1991), The decline of the Social Survey Movement and the rise of American empirical sociology, in: M. Bulmer, K. Bales, K.K. Sklar (eds.), The social survey in historical perspective 1880-1940, Cambridge: 291-315.

Cahnman, W.J. (1973), Ferdinand Tönnies. A New Evaluation. Essays and Dacuments, Leiden.

Carey, J.T. (1975), Sociology and Public Affairs: The Chicago School, Beverly Hills/London.

Carnegie, A. (1900), Popular Illusions About Trusts, in: Century, 60.

Chalmers, A. (1981), Wat heet wetenschap, Meppel. (Vert. van What is this thing called science?, Queensland 1976)

Chapin, F.S. (1917), The Experimental Method and Sociology, in: Scientific Monthly 4: 133-43; 238-47.

Chapin, F.S. (1936), Social Theory and Social Action, in: American Sociological Review 1: 1-11.

Chapin, F.S. (1947), Experimental Designs in Sociological Research, New York.

Christakes, G. (1978), Albion W. Small, Boston.

Church, R.L. (1974), Economists as Experts: The Rise of an Academic Profession in America 1870-1917, in: L. Stone, ed., The University in Society, vol. II, Princeton: 571610.

Churgerman, S. (1965), Lester F. Ward: The American Aristotle, New York.

Coats, AW. (1961), American Scholarship Comes of Age: The Louisiana Purchase Exposition 1904, in: Journal of the History of Ideas 22: 404-17. 
Collins, R., M. Makowski (1974), Het verschijnsel maatschappij, Meppel. Vert. van The discoveny of society, New York 1972.

Comte, A (1822), Prospectus des travaux néccesaires pour organiser la societé, in: idem, Ecrits de Jeunesse 1816-1828, Archives Positivistes, Paris/La Haye, 1970.

Cooley, C.H. (1920), Reflections upon the Sociology of Herbert Spencer, in: AJS 26: 129-45.

Cornelisse, F.H. (1985), Inleiding tot de wetenschapsfilosofie, Deventer.

Coser, L.A. (1971), Masters of Sociological Thought. Ideas in historical and social context, New York etc.

Cravens, H. (1978), The Triumph of Evolution, Philadelphia.

Curti, M., V. Carstensen (1949), The University of Wisconsin:" A history, Madison.

Dahme, H-J. (1981), Soziologie als exakte Wissenschaft. Georg Simmels Ansatz und seine Bedeutung in der gegenwärtigen Soziologie, 2 Teile, Stuttgart.

Dahrendorf, R. (1968), Die angewandte Aufkldrung. Gesellschaft und Soziologie in Amerika, Frankfurt a.M.

Dahrendorf, R. (1971), Gesellschaft und Demokratie in Deutschland, München.

Deegan, M.J. (1988), Jane Addams and the Men of the Chicago School, 1892-1918, Chicago.

Dehue, T. (1990), De regels wan het vak. Nederlandse psychologen en hun methodologie 1900 1985, Amsterdam.

Derksen, A.A. (1980), Rationaliteit en Wetenschap, Assen.

Dewey, J. (1920), Reconstruction in Philosophy, Boston.

Dewey, J. (1922), Human Nature and Conduct. An Introduction to Social Psychology, New York.

Dibble, V.K. (1975), The Legacy of Albion Small, Chicago.

Diner, S.J. (1975), 'Department and Discipline: The Department of Sociology at the University of Chicago, 1892-1920', in: Minerva, 8: 514-553.

Diner, S.J. (1980), A City and its Universities: Public Policy in Chicago, 1892-1919, Chapell Hill.

Dolby, R.G.A. (1979), Classification of the Sciences. The Nineteenth Century Tradition, in: Ellen/Reason (1979).

Doorn, J.A.A van, C.J. Lammers (1968), Modeme Sociologie. Systematiek en analyse, 9e druk, Utrecht/Antwerpen. 
Döring, H. (1975), Der Weimarer Kreis, Studien zum politischen Bewusstsein verfassungstreuer Hochschullehrer in der Weimarer Republik, Meisenheim.

Dowling, R.E. (1960), Pressure Group Theory: Its Methodological Range, in: The American Political Science Review 54: 944-54.

Dubiel, H. (1978), Wissenschaftsorganisation und politische Erfahrung. Studien zur frilhen Kritischen Theorie, Frankfurt a.M..

Dupree, A.H. (1980), Science in the Federal Government, New York.

Düwell, K (1971), Staat und Wissenschaft in der Weimarer Epoche, Zur Kulturpolitik des Ministers C.H. Becker, in: Historische Zeitschrift, Beiheft 1, München 1971: 31-74.

Editorial Notes (1922), The Journal of Social Forces 1.

Eisermann, G. (1968), Alfred Vierkandt, in: idem, Bedeutende Soziologen, Stuttgart.

Elias, N. (1971), Wat is Sociologie?, Utrecht/Antwerpen.

Elias, N. (1982a), Scientific Establishments, in: N. Elias et.all. (1982).

Elias, N. (1982b), Problemen van betrokkenheid en distantie, Amsterdam.

Elias, N., H. Martins, R. Whitley (eds.) (1982), Scientific Establishments and Hierarchies, Dordrecht.

Ellen, R.F., D. Reason (eds.) (1979), Classifications in their social context, London/New York.

Ellwein, T. (1985), Die deutsche Universitat. Vom Mittelalter bis zur Gegenwart, Konigstein.

Ellwood, C.A. (1909), The psychological view of society, in: Publ. of the ASS 4: 62-84.

Ellwood, C.A. (1930), Scientific Method in Sociology, in: Social Forces 8: 15-21.

Ellwood, C.A. (1939), De psychologie van de menschelijke samenleving. Een inleiding in de theorie van de sociologie, Amsterdam.

Emerson, R.W. (1883), Essays. Second Series, London.

Emmerich, E. (1958), 50 Jahre Volkshochschule in Deutschland, Berlin.

Factor, R.A., S.P. Turner (1982), Weber's influence in Weimar Germany, in: Journal of the History of the Behavioral Sciences 18: 147-156.

Faris, R.E.L. (1967), Chicago Sociology, 1920-1932, San Francisco.

Fine, W.F. (1979), Progressive Evolutionism and American Sociology, 1890-1920.

Fine, G.A., J.S. Severance (1985), Great men and hard times: sociology at the University of Minnesota, in: The Sociological Quarterly 26: 117-34. 
Fleischmann, E. (1964), De Weber a Nietzsche, in: Archives Européennes de Sociologie 5: 190-238.

Fogt, H. (1981), Max Weber und deutsche Soziologie der Weimarer Republik: Aussenseiter oder Gründervater?, in: Lepsius (1981): 245-272

Ford, H.J (1909), The Pretensions of Sociology, in: AJS 15: 96-105.

Fornefeld, G., A. Lückert, K. Wittebur (1986), Die Soziologie an den reichsdeutschen Hochschulen zu Ende der Weimarer Republik. Versuch einer Bestandsaufnahme, in: Papcke (1986): 423-42.

Foss, D.C. (1977), The Value Controversy in Sociology, San Francisco.

Freyer, H. (1932), Soziologie als Wirklichkeitswissenschaft, in: R. Thurnwald (Hrsg), Soziologie von Heute, Leipzig.

Freyer, H. (1934), Von der Volksbildung zur politischen Schulung, in: Die Erziehung: Monatschrift fulr den Zusammenhang von Kultur und Erziehung in Wissenschaft und Leben g: 1-12.

Furner, M.O. (1975), Advocacy \& Objectivity. A Crisis in the Professionalization of American Social Science, 1865-1905, Lexington.

Gastelaars, M. (1985), Een Geregeld Leven: Sociologie en Sociale Politiek in Nederland 1925-1968, Amsterdam.

Giddens, A. (1977), Four myths in the history of social thought, in: idem, Studies in Social and Political Theory, London.

Giddings, F.H. (1897), The Theory of Socialization, New York.

Giddings, F.H. (1896), The destinies of democracy, in: Political Science Quarterly 2: 71631.

Giddings, F.H. (1904), A theory of social causation, in: Publications of the American Economic Association 5: 139-199 (incl. verslag van de discussie).

Giddings, F.H. (1910), The relation of social theory to public policy, in: ASS 5: 2-16.

Giddings, F.H. (1912), The quality of civilization, Presidential Address, in: ASS 6: 1-9.

Gieryn, T.F. (1983), 'Boundary-work and the demarcation of science from non-science', in: American Sociological Review, 48: 781-795.

Glenn, J.M., L Brandt, F.E. Andrews (1947), Russell Sage Foundation 1907-1946, 2. Vol., New York.

Gombrich, E. H. (1960), Art and Illusion. A study in the psychology of pictorial representation, Oxford.

Goodman, N. (1978), Ways of Worldmaking, Indianapolis. 
Goodman, N., C.Z. Elgin (1988), Reconceptions in Philosophy \& Other Arts and Sciences, London.

Gorges, I. (1986a), Sozialforschung in Deutschland 1872-1914, Frankurt a.M..

Gorges, I. (1986b), Sozialforschung in der Weimarer Republik 1918-1933, Frankfurt a.M..

Gouldner, A. (1964), Anti-Minotaur: The Myth of a Value-Free Sociology, in: I.L. Horowitz (ed.), The New Sociology, New York.

Gouldner, A.W. (1970), The Coming Crisis of Westem Sociology, New York:

Graham, L., W. Lepenies, P. Weingart (eds.) (1983), Functions and Uses of Disciplinary Histories, Dordrecht.

Graham. L.R. (1981), Between Science and Values, New York.

Gray, J. (1951), The University of Minnesota 1851-1951, Minneapolis.

Greene, G. (1984), Getting to Know the General, New York.

Greenwood, E. (1945), Experimental Sociology. A study in method, New York.

Guntau M., H. Laitko (Hrsg.) (1987), Der Ursprung der modernen Wissenschaften. Studien zur Entstehung wissenschaftlicher Disziplinen, Berlin.

Habermas, J. (1990), Sociologie in de Weimarrepubliek, in: Kennis en Methode 14: 367. 383.

Hacking, I. (1982), Language, Truth and Reason, in: M. Hollis, S. Lukes (eds.), Rationality and Relativism, Oxford.

Hale, M.Q. (1960), The Cosmology of Arthur F. Bentley, in: The American Political Science Review 54: 955-61.

Hanover Conference (1928), Notes of the Monday Evening Session, August 20, 1928, Library Univ. of Chicago.

Harbers, H. (1986), Saciale wetenschappen en hun speelruimte, Groningen.

Hardin, B. (1977), The Professionalization of Sociology. A comparative study: GermanyUSA, Frankfurt/New York.

Harrison, E. (1987), Whigs, Prigs and historians of science, in: Nature 329, 17 sept.: 213214.

Haselbach, D. (1984), Franz Oppenheimer. Soziologie, Geschichtsphilosophie und Politik des 'Liberalen Sozialismus', Opladen.

Haskell, T.A. (1984), Professionalism versus Capitalism: R.H. Tawney, Emile Durkheim, and C.S. Peirce on the Disinterestedness of Professional Communities, in: idem (ed.), The Authority of Experts, Bloomington. 
Haskell, T.L. (1977), The Emergence of Professional Social Science. The American Social Science Association and the nineteenth-century crisis of authority, Urbana/Chicago/London.

Hawthorn, G. (1976), Enlightenment \& Despair. A history of sociology, Cambridge.

Hayes, E.C. (1911), The "Social Forces" Error, in: Publications of the American Sociological Society 5: 77-89.

Heilbron, J. (1990), Het ontstaan van de sociologie, Amsterdam.

Heilbron, J. (1983), Het paradoxale succes van Emile Durkheim, in: H.P.M. Goddijn en D. Pels (red.), Emile Durkheim en zijn opponenten, themanummer (Amsterdams) Sociologisch Tijdschrift, 10.

Helle, H.J. (1988), Soziologie und Erkennistheorie bei Georg Simmel, Darmstadt.

Helmes-Hayes, R.C. (1987), 'A dualistic vision': Robert Ezra Park and the classical ecological theory of social inequality, in: The Sociological Quarterly 28: 387-409.

Henderson, C.R. (1898), Social Elements: Institutions, Character, Progress, New York.

Henderson, C.R. (1901), The Scope of Social Technology, in: AJS 6: 465-86.

Hentschel. V. (1983), Geschichte der deutschen Sozialpolitik 1880-1980. Neue Historische Bibliothek, Frankfurt am Main.

Herbst, J. (1959), 'From Moral Philosophy to Sociology: Albion Woodbury Small', in: Harvard Educational Review, 29: 227-244.

Herbst, J. (1988), American Higher Education in the Age of the College, in: History of Universities $7: 37-59$.

Herkner, H. (1912), Der Kampf um das sittliche Werturteil in der Nationalökonomie, in: Schmollers Jahrbuch, 36.

Higham, J. (1965), Histon, Princeton Studies in Humanistic Scholarship in America, Englewood Cliffs, N.J..

Hinkle, R.C. (1980), Founding Theory of American Sociology, 1881-1915, Boston/London.

Hinkle, R.C., en G.J. Hinkle (1954), The Development of Modern Sociology, New York.

Hofstadter, R. (1944), Social Darminism in American Thought, Boston 1955.

Hofstadter, R. (1963), Anti-Intellectualism in American Life, New York.

Hofstadter, R. (1968), The Progressive Historians: Tumer, Beard, Parrington, London.

Hollander, A.N.J. den (1976), Het démasqué in de samenleving, Amsterdam.

House, F.N. (1925/6), The Concept of 'Social Forces' in American Sociology, in: AJS 31: $145-72 ; 347-85 ;, 507-25 ; 763-99$. 
Houten, B.C. van (1973), Tussen aampassing en kritiek De derde methodenstrijd in de Duitse saciologie, Deventer.

Howerth, I.W. (1894-1895), 'Present condition of sociology in the United States, Amnals of the American Academy of Political and Social Science, 5.

Hoxie, R.E. (1907), Sociology and the Other Social Sciences, in: AJS 12: 739-55.

Hull, D.L. (1988), Sience as a Process. An evolutionary Account of the Social and Conceptual Development of Science, Chicago/London.

Informal Conference (1913), Is it possible for american sociologists to agree upon a constructive program? in: Publications of the American Sociological Society 8: 159-168.

Jacoby, E.G. (1971), Die moderne Gesellschaft im sozialwissenschaftlichen Denken von Ferdinand Tönnies, Stuttgart.

Jahnke, H.N., M. Otte (eds.) (1981), Epistemological and Social Problems of the Sciences in the Early Nineteenth Century, Dordrecht.

James, W. (1907), Pragmatism. A New Name for Some Old Ways of Thinking, New York/London, Reprint 1931.

Janowitz, M. (1972), Professionalisation of Sociology, in: AJS 78: 105-35.

Janssen, P.L. (1985), Political thought as traditionary action: the critical response to Skinner and Pocock, in: History and Theory 24: 115-46.

Jonas, F. (1969), Geschichte der Soziologie, Bd. IV, Reinbek bei Hamburg.

Jones, R.A. (1985), Durkheim and the positive science of ethics in Germany, in: History of Sociology 6: 177-89.

Kaplan, J. (1974), Lincoln Steffens, A Biography, New York.

Kappe, H. (1964), Volksbildung und Volkbildung. Geschichte und Idee der Reichsverbandes der deutschen Volkshochschulen, Münster.

Karl, B.D. (1963), Executive Reorganization and Reform in the New Deal. The Genesis of Administrative Management, 1900-1939, Cambridge Mass..

Karl, B.D. (1969), Presidential Planning and Social Science Research: Mr. Hoover's Experts, in: Perspectives in American History 3: 347-407.

Käsler, D. (1981), Der Streï um die Bestimmung der Soziologie auf den Deutschen Soziologentagen 1910-1930, in: Lepsius (1981): 199-244.

Käsler, D. (1984), Die frithe deutsche Soziologie 1909 bis 1934 und ihre EntstehungsMilieus: Eine wissenschaftssaziologische Untersuchung, Opladen.

Käsler, D. (1985), Soziologische Abentewer. E.E. Eubank besucht europaische Soziologen in Sommer 1934, Opladen. 
Kettler, D., V. Meja, N. Stehr (1984), Karl Mannheim, Chichester/London/New York.

Kevles, D. (1979), The Physics, Mathematics, and Chemistry Communities: A Comparative Analysis, in: Oleson/Voss (1979).

King, M.D. (1971), Reason, tradition, and the progressiveness of science, in: History and Theory 10, 3-32.

Kinloch, G.C. (1984), The changing definition and content of sociology in introductory textbooks 1894-1981, in: International Review of Modern Sociology 14: 89-103.

Klein, P. (1968), From Philanthropy to Social Welfare: an American Cultural Perspective, San Francisco.

Klingemann, C. (1981), Heimatssoziologie oder Ordnungsinstrument? Fachgeschichtliche Aspekte der Soziolgie in Deutschland 1933-1945, in: Lepsius (1981): 273-307.

Köbben, AJF. (1991), De weerbarstige waarheid. Opstellen over wetenschap, Amsterdam.

Koenis, S. (1991), Tussen Marge en Professie. Frankfurt en Chicago: twee visies op de praktische rol van sociologen, Amsterdam.

König, R., J. Winckelmann (Hrsg.) (1963), Max Weber zum Gedachtmis, KZSS Sonderheft 7.

König, R. (red.) (1967), Sociologie, Antwerpen-Utrecht.

Koningsveld, H. (1976), Het verschijnsel wetenschap. Een inleiding tot de wetenschapsfilosofie, Meppel.

Kossmann, E. H. (1986), De Lage Landen 1780/1980. Twee eeuwen Nederland en België, deel II, Amsterdam/Brussel.

Krüger, L (1987), Einheit der Welt - Vielheit der Wissenschaft, in: J. Kocka (Hrsg.), Interdisziplinaritat. Praxis-Herausforderung-Ideologie, Frankfurt a.M..

Kruse, V. (1990), Von der historischen Nationalökonomie zur historischen Soziologie, in: Zeitschrift fur Soziologie 19: 149-165.

Kuhn, T.S. (1984), Scientific Development and Lexical Change. The Thalheimer Lectures, Johns Hopkins University 12 to 19 November 1984 (ongepubl. manuscript).

Kuklick, B. (1985), Churchmen and Philosophers: from Jonathan Edwards to John Dewey, New Haven/London.

Kuklick, H, (1973), A 'scientific revolution': Sociological theory in the United States 1930-1945, in: Sociological Inquiry 43: 3-22.

Kuklick, H. (1980b), Restructuring the Past: toward an appreciation of the social context of social science, in: The Sociological Quarterly 21: 5-21.

Kuklick, H. (1980a), Boundary Maintenance in American Sociology: Limitations to Academic "Professionalisation", in: Joumal of the History of the Behavioral Sciences 16: 201-19. 
Kurucz, J. (1967), Struktur und Funktion der Intelligenz wathrend der Weimarer Republik, Köln.

Laqueur, W.Z (1962), Young Germany. A History of the German Youth Movement, London.

Lenk, K (1963), Die Rolle der Intelligenzsoziologie in der Theorie Mannheims, in: KZSS 15: 323-37.

Lenk, K (1964), Das tragische Bewusstsein in der deutschen Soziologie, in: Kolmer Zeitschrift für Soz. und Sozialpsych., 16: 257-287.

Lepenies, W. (1976), Das Ende der Naturgeschichte. Wandel kultureller Selbstverstandlichkeiten in den Wissenschaften des 18. und 19. Jahrhunderts, München.

Lepenies, W. (1978), Wissenschaftsgeschichte und Disziplingeschichte, in: Geschichte und Gesellschaft 4: 437-51.

Lepenies, W. (Hrsg.) (1981), Geschichte der Soziologie. Studien zur kognitiven, sozialen und historischen Identităt einer Disziplin, 4 Bände, Frankfurt am Main.

Lepenies, W. (1985), Drei Kulturen. Soziologie zwischen Literatur und Wissenschaft, München/Wien.

Lepsius, M.R. (Hrsg.) (1981), Soziologie in Deutschland und Oesterreich 1928-1945, KZSS Sonderheft 23.

Levine, D.N. (1976), Simmel's Infuence on American Sociology, in: AJS 81: 813-845; 1112-1131.

Linde, H. (1981), Soziologie in Leipzig 1925-1945, in: Lepsius (1981): 102-130.

Lindenlaub, D. (1967), Richtungskampfe im Verein fur Sozialpolitik, Wiesbaden.

Lorenz, C. (1987), De constructie van het verleden. Een inleiding in de theoric van de geschiedenis, Meppel.

Lukács, G. (1954), Die Zerstörung der Vermunft, Neuwied/Berlin.

Lundberg, G.A. (1942), Social Research: A study in methods of gathering data, New York (herziene druk van oorspr. uitgave 1929).

Macintyre, A. (1981), After Virtue, London.

Maclean, A.M. (1903), The Sweat-Shop in Summer, in: AJS 9: 292-309.

Manicas, P.T. (1988), A History \& Philosophy of the Social Sciences, Oxford.

Manicas, P.T. (1991), The Social Science Disciplines: The American Model, in: P. Wagner et.al. (1991).

Martindale, D. (1976), The Romance of a Profession. A case history in the sociology of sociology, St. Paul, Minn.. 
Matthes, J. (1973), Einfuhrung in das Studium der Soziologie, Reinbek.

Matthes, J. (1973), Einfuhrung in das Studium der Soziologie, Reinbek bei Hamburg: 236.

Matthews, F.H. (1977), Quest for an American Sociology. Robert E. Park and the Chicago School, Montreal/London.

Mayr, E. (1990), When is historiography Whiggish? in: Joumal of the History of Ideas 51: $301-9$.

McCosh, J. (1887), Realistic Philosophy, 2 vol., New York.

McCosh, J. (1875), The Scottish Philosophy, Hildesheim 1966.

Mead, G.H. (1938), The Philosophy of the Act, Works vol. 3, edited by C.W. Morris, Chicago/London.

Meinecke, F. (1922), Drei Generationen deutscher Gelehrtenpolitik, in: Historisch Zeitschrift Bd.125: 248-283.

Mendelsohn, E., P. Weingart, R. Whitley, eds. (1977), The Social Production of Scientific Knowledge, Dordrecht.

Mills, C.W. (1943), The professional ideology of social pathologists, in: AJS 49: 165-80.

Mol, A (1988), The pacification of controversies in medicine, paper gepresenteerd op de 4S/EASST conferentie te Amsterdam.

Mommsen, W. (1974), Max Weber. Gesellschaft, Politik und Geschichte, Frankfurt a.M..

Mommsen, W. (1959), Max Weber und die deutsche Politik 1890-1920, Tübingen.

Morrison, T: (1974), Chautauqua, A Center for Education, Religion, and the Arts in America, Chicago.

Nagel, E. (1961), Der Einfluss von Wertorientierungen auf die Sozialforschung, in: $\mathrm{H}$. Albert, E. Topitsch (Hrsg, ), Werurteilsstreit, Darmstadt 1979.

Nash, C., (ed.) (1990), Narrative in Culture. The uses of storytelling in the sciences, philosophy, and literature, London/New York.

Nauta, L.W. (1971), Wetenschap en waardevrijheid, in: idem, Argumenten voor een kritische ethiek, Amsterdam.

Nauta, L., G. de Vries (1979), Maatschappij of Methode. Bijdragen tot het internalisme/extemalisme debat. Themanummer Kennis en Methode 3.

Nipperdey, T. (1973), Interessenverbande und Parteien in Deutschland vor den ersten Weltkrieg, in: H-U. Wehler (Hrsg.), Moderne deutsche Sozialgeschichte, Köln.

Nolte, E. (1973), Ideologie, Engagement, Perspektive, in: G. Schultz (Hrsg.), Geschichte heute. Positionen, Tendenzen und Probleme, Götingen. 
Oakes, $G_{*}$. (1982), Methodological Ambivalence: The Case of Max Weber, in: Social Research 49: 589-615.

Oberschall, A. (1965), Empirical Social Research in Germany 1848-1914, Paris/The Hague.

Obershall, A. (1972), The Institutionalization of American Sociology, in: idem, ed., The Establishment of Empinical Sociology: Studies in Continuity, Discontinuity, and Institutionalization, New York, etc: 187-251.

Oleson, A. J. Voss (eds.) (1979), The Organisation of Knowledge in Modern America, 1860-1920, Baltimore/London.

Pankoke, E. (1977), Sozialpolitik zwischen staatlicher Systematisierung und situativer Operationalisierung. Zur Problem- und Programmgeschichte sozialer Politik, in: $C_{\text {. von }}$ Ferber, F.X. Kaufmann (Hrsg.), Soziologie und Sozialpolitik, KZSS Sonderheft 19.

Papcke, S. (1985), Gesellschaftsfähig? Soziologische Vereinsbildung in Deutschland, in: idem, Vernunf und Chaos. Essays zur sozialen Ideengeschichte, Frankfurt am Main.

Papcke, S. (1986), Weltferne Wissenschaft. Die deutsche Soziologie der Zwischenkriegszeit vor dem Problem des Faschismus/Nationalsozialismus, in: idem (Hrsg.), Ordnung und Theorie. Beiträge zur Geschichte der Soziologie in Deutschland, Darmstadt: 168-222.

Park, R.E., E.W. Burgess (1921), Introduction to the Science of Sociology, Chicago.

Parsons, T. (1959), Some Problems Confronting Sociology as a Profession, in: American Sociological Review 24: 547-559.

Parsons, T. (1965a), Unity and Diversity in the Modern Intellectual Disciplines, in: Daedalus 94: 39-65.

Parsons, T. (1965b), Max Weber 1864-1964, in: American Sociological Review 30: 171-175.

Parsons, T. (1971), Value-freedom and objectivity, in: O Stammer (ed.), Max Weber and sociology today, Oxford.

Pasveer, B. (1992), Shadows of Knowledge. Making a representing practice in medicine" $x_{-}$ ray pictures and pulmonary tuberculosis, 1895-1930, Amsterdam.

Paul, E.F. (1983), Herbert Spencer: the historicist as a failed prophet, in: Joumal of the History of Ideas 44: 619-38.

Peel, J.D.Y. (1971), Herbert Spencer: the evolution of a sociologist, New York.

Peirce, C.S. (1931-1953), Collected Papers, Vol. I-VI, ed. by C. Hartshorne and P. Weiss, Cambridge Mass..

Pels, D. (1987), Macht of Eigendom. Een kwestie van intellectuele rivaliteit, Amsterdam.

Perelman, Ch., L. Olbrechts-Tyteca (1969), The New Rhetoric. A treatise on Argumentation, Notre Dame. 
Pfautz, H.W., 'Ward, Lester F.', in: The International Encyclopedia of the Social Sciences, New York 1968.

Plessner, H. (1959), Die verspätete Nation: Ueber die politische Verfuhrbarkeit bürgerlichen Geistes, Stuttgart.

Pocock, J.G.A (1985), Virtue, Commerce, and History. Essays on Political Thought and History, Chiefly in the Eighteenth Century, Cambridge.

Pocock, J.G.A. (1971), Politics, Language and Time. Essays on Political Thought and History, London.

Polak, F.L. (1948), Kennen en keuren in de sociale wetenschappen, Leiden.

Pott, H. (1992), De liefde van Alcibiades. Emoties, Rationaliteit en de Transformatie van de Filosofie, Amsterdam (te verschijnen).

Potts, D.B. (1965), Social Ethics at Havard, 1881-1931. A sudy in Academic Activism, in: P. Buck (ed.), Social Sciences at Harvard 1860-1920, Cambridge Mass..

Prahl, H-W. (1986), Der Streit um die Vaterschaft. Die Anfänge der soziologie in der sicht deutscher Soziologen vor 1933, in: Papcke (1986): 48-68.

Quinn, D. (1896), The Duty of Higher Education in our Times, in: Journal of Social Science 27: 15-24.

Rademaker, L. (red.) (1978), Sociologische encyclopedie, deel 3, Utrecht/Antwerpen.

Rammstedt, O. (1988a), Wertfreiheit und die Konstitution der Soziologie in Deutschland, in: Zeitschrift fü Soziologie 17: 264-271.

Rammstedt, O. (Hrsg.) (1988b), Simmel und die fruhen Soziologen. Nähe und Distanz zu Durkheim, Tönnies und Max Weber, Frankfurt am Main.

Reinisch, L. (Hrsg.) (1961), Die Zeit ohne Eigenschaften, Eine Bilanz der zwanziger Jahre, Stuttgart.

Reuter, E. B., CW. Hart (1933); Introduction to Sociology, New York/London.

Reve, K. van het (1970), Marius wil niet in Joegoslavië wonen, Amsterdam.

Rickert, H. (1902), Grenzen der naturwissenschaftlichen Begriffsbildung, Tübingen.

Rickert, H. (1921), Kulturwissenschaft und Naturwissenschaft, Tübingen (4. u. 5. Aufl.).

Rijk, L.M. de (1979), Facts and Events: The Historian's Task, in: Vivarium 17: 1-42.

Ringer, F.K. (1979), The German Academic Community, in: Oleson/Voss (1979).

Ringer, F.K. (1969), The decline of the German mandarins. The German Academic Community 1890-1933, Cambridge Mass. 
Rogers, H.J. (ed.) (1905-1907), Congress of Aits and Science, Universal Exposition, St. Louis, 1904, New York.

Rorty, R. (1982), Consequences of Pragmatism, Minneapolis.

Rorty, R. (1990), Solidariteit of objectiviteit. Drie filosofische essays, Meppel.

Rorty, R. (1991), Objectivity, Relativism, and Truth, Philosophical Papers Vol. 1, Cambridge.

Rosenberg, H. (1967), Grosse Depression und Bismarckzeit, Berlin.

Ross, E.A. (1901), Social Control. A Survey of the Foundations of Order, New York/London 1928.

Ross, E.A. (1903-1904), Moot points in sociology: the social forces, in: AJS 9: 526-48.

Ross, E.A. (1905), Foundations of Sociology, New York/London.

Ross, E.A. (1907), Sin and Society: an analysis of latter day iniquity, Boston/New York.

Ross, D. (1991), The Origins of American Social Science, Cambridge.

Rouse, J. (1987), Knowledge and Power. Toward a political philosophy of science, Ithaca/ London.

Samelson, F. (1985), Organizing for the kingdom of behavior: academic battles and organizational policies in the twenties, in: Joumal of the Hist. of the Behav. Sciences 21: 33-47.

Sanborn, F.B. (1884); The Commonwealth of Social Science, in: Joumal of Social Science 15: 1-10.

Sanborn, F.B. (1885), The Social Sciences. Their Growth and Future, in: Joumal of Social Science 16: 1-12.

Sanborn, F.B. (1890), The Work of Twenty-Five Years. A report by the general secretary, in: Joumal of Social Science 21: 43-49.

Satris, S.A. (1982), The theory of value and the rise of ethical emotivism, in: Journal of the History of Ideas 43: 109-128.

Scaff, L.A. (1986), Culture, philosophy, and politics: the formation of the sociocultural sciences in Germany, in: History of the Human Sciences 1: 221-243.

Schäfers, B. (Hrsg.) (1967), Soziologie und Sozialismus, Organisation und Propaganda, Abhandlungen zum Lebenswerk von Johann Plenge, Stuttgart.

Scheler, M. (1921), Uber die positivistische Geschichtsphilosophie des Wissens, in Gesammelte Werke, Bd. 6.

Scheler, M. (Hrsg.) (1924), Versuche zu einer Soziologie des Wissens, München-Leipzig. 
Scheler, M. (1928), Probleme einer Soziologie des Wissens, in: Gesammelte Werke, Bd. 6.

Scheler, M. (1963), Gesammelte Werke, Bd. 6, Bern/München.

Schelsky, H. (1959), Ortbestimmung der deutschen Soziologie, Düsseldlorf/Köln.

Schelsky, H. (1961), Einsamkeit und Freiheit, Idee und Gestalt der deutschen Universität und ihrer Reformen, Reinbek bei Hamburg.

Scheuch, E.K, T. Kutsch (1975), Grundbegriffe der Soziologie, Teil 1: Grundlegung und Elementäre Phänomene, Stuttgart.

Schivelbusch, W. (1982), Intellektuellendammerung. Zur Lage der Frankfurter Intelligenz in den zwanziger Jahren, Frankfurt/Main.

Schluchter, W. (1978), Max Webers Gesellschaftgeschichte, in: KZSS 30: 438-467.

Schmoller, G. (1872), Eroffnungsrede bei der Eisenacher Tagung des Vereins für Sozialpolitik, in: F. Boese (1939).

Schmoller, G. (1883), Die Schriften von K. Menger und W. Dilthey zur Methodologie der Staats- und Sozialwissenschaften, in: Schollers Jahrbuch 7: 275-304.

Schmoller, G. (1893), Die Volkswirtschaft, die Volkswirtschaftslehre und ihre Methode, Frankfurt am Main 1949.

Schmoller, G. (1897a), Wechselnde Theorien und feststehende Wahrheiten im Gebiete der Staats- und Sozialwissenschaften und die heutige deutsche Volkswirtschaftslehre, in: Schmollers Jahrbuch, 21: 240-264.

Schmoller, G. (1897b), Zur 25 jährigen Feier des Vereins für Sozialpolitik, in: idem, Zwanzig Jahre deutscher Politik, Berlin 1901.

Schmoller, G. (1898), Uber einige Grundfragen des Rechts und die Volkswirtschaft (1874/1875), in: idem, Uber einige Grundfragen des Sozialpolitik und der Volkswirtschaftlehre, Leipzig.

Schmoller, G. (1912), Einleitungsworte bei der Nürnberger Tagung des Vereins für Sozialpolitik (1911), in: Schmollers Jahrbuch 36: 1-12.

Schneider, H.W. (1946), A History of American Philosophy, New York.

Schumpeter, J.A. (1954), History of Economic Analysis, New York.

Schuster, J.A., R.R. Yeo (eds.) (1986), The Politics and Rhetoric of Scientific Method: Historical Studies, Dordrecht.

Schuyt, C.J.M. (1982), Het pragmaticisme van Charles Sanders Peirce, in: Kennis en Methode 6: 252-75.

Schuyt, C.J.M. (1986), Filosofie van de sociale wetenschappen, Leiden. 
Schuyt, C.J.M. (1988), De betekenis van betekenissystemen, in: Kennis en Methode 12: 130-37.

Seidman, S., R.K. Merton, R.A Jones (1985), Debate on Presentism and Historicism, in: History of Sociology 6: 121-60.

Shapin, S. (1982), History of Science and its Sociological Reconstructions, in: History of Science 20: 157-211.

Shapin, S., S. Schaffer (1985), Leviathan and the Air-Pump. Hobbes, Boyle, and the experimental life, Princeton.

Shils, E. (1975), Geschichte der Soziologie: Tradition, Ökologie und Institutionalisierung, in: T. Parsons u.a., Soziologie-autobiografisch, Stuttgart.

Sica, A. (1988), Weber, Irrationality, and Social Order, Berkeley/Los Angeles/London.

Silva, E.T., S.A. Slaughter (1984), Serving Power: The Making of the Academic Social Science Expert, Westport, Conn.

Simmel, G. (1908), Soziologie, Berlijn.

Skinner, Q. (1969), Meaning and Understanding in the History of Ideas, in: History and Theory, 8: 3-53.

Small, A.W. (1895), The Era of Sociology, in: AJS 1: 1-15.

Small, A.W. (1896), Scholarship and social agitation, in: AJS 1: $564-582$.

Small, A.W. (1897), Some demands of sociology upon pedagogy, in: AJS 2: 839-851.

Small, A.W. (1898), "The sociologists' point of view', in: AJS 3: 145-170.

Small, A.W. (1900), 'The scope of Sociology: IV' in: AJS, 6: 34-62.

Small, A.W. (1903a), What is a sociologist?, in: AJS 8: 468-477.

Small, A.W. (1903b), The significance of sociology for ethics, in: The Decennial Publications of the University of Chicago, First Series 4: 3-39.

Small, AW. (1905), General Sociology. An Exposition of the Main Development in Sociological Theory from Spencer to Ratzenhofer, Chicago.

Small, A.W. (1906a), The relation between sociology and other social sciences, in: AJS 12: $11-42$.

Small, A.W. (1906b), Points of Agreement Among Sociologists, in: Publications of the American Sociological Society 1: 55-77 (incl. verslag van de discussie).

Small, A.W. (1907), Are the social sciences answerable to common principles of method? in: AJS 13: 1-24.

Small, A.W. (1916), Fifty years of sociology in the United States, in: AJS 21: 721-864. 
Small, A.W., G.E. Vincent (1894), An Introduction to the Study of Sociology, New York/Chicago.

Smith, C.U.M. (1982), Herbert Spencer, in: Joumal of the History of Biology 15: 55-88.

Spencer, H. (1851), Social Statics, London.

Spencer, H. (1862), First Principles, A System of Synthetic Philosophy vol. I, London/Edinburgh.

Spencer, H. (1876), The Principles of Sociology, vol. I, New York 1899.

Spencer, H. (1972), On Social Evolution, Ed. J.D.Y. Peel, Chicago/London.

Speziali, P. (1973-1974), Classification of the Sciences, in: Dictionary of the History of Ideas.

Staude, J.R. (1967), Max Scheler 1874-1928, An intellectual Portrait, New York.

Steffens, L. (1909), Sending a State to College. What the University of Wisconsin is doing for its people, in: The American Magazine: 349-64.

Stern, B.J. (ed.) (1932-1937), 'The Letters of Albion W. Small to Lester F. Ward', in: Social Forces, 12: 163-173; 13; 323-340; 14: 174-186; 15: 305-327.

Stichweh, R. (1984), Zur Enrstehung des modernen Systems wissenschafrlicher Disziplinen. Physik in Deutschland 1740-1890, Frankfurt a.M..

Stocking, G.W. (1962), Lamarckianism in American Social Science 1890-1915, in: Joumal of the History of Ideas $23: 239-56$.

Stölting E. (1986), Soziologie und Nationalökonomie: Die Wirkung des institutionellen Faktors, in: S. Papcke (Hrsg.), Ordnung und Theorie. Beiträge zur Geschichte der Soziologie in Deutschland, Darmstadt.

Storr, R.J. (1966), Harper's University: The Beginnings, Chicago.

Stuhlmann-Laeisz, R. (1986), Uber das logische Verhältnis zwischen Normen und Tatsachen, in: Allgemeine Zeitschrift für Philosophie 11: 17-29.

Suranyi-Unger, T. (1927), Die Entwicklung der theoretischen Volkswirtschaftslehre im ersten Viertel des 20. Jahrhunderts, Jena.

Swart, K.W. (1962), "Individualism" in the mid-nineteenth century, in: Journal of the History of Ideas 23: 77-90.

Tenbruck, F.H., (1959), Die Genesis der Methodologie Max Webers, in: KZSS 11: 573630.

Tenbruck, F.H. (1981), Emile Durkheim oder die Geburt der Gesellschaft aus dem Geist der Soziologie, in: Zeitschrift für Soziologie 10: 330-50. 
Tenbruck, F.H., (1986) Das Werk Max Webers: Methodologie und Sozialwissenschaften, in: KZSS 38: 13-31.

Thomas, W.I. (1907), Sex and Society, Chicago.

Thomas, W.I., F. Znaniecki (1918-1920), The Polish Peasant in Europe and America, 5 vol., Boston.

Tijmes, P. (1977), Over politiek valt met rede te twisten. Een onderzoek naar de rol van wetenschap en ethiek in het politieke denken van Mar Weber, Meppel/Amsterdam.

Tolman, F.L. (1901/2), Study of Sociology in Institutions of Learning in the United States, AJS 7: 797-838; 8: 85-121; 251-273; 531-563.

Tönnies, F. (1912), Gemeinschaft und Gesellschaft. Grundbegriffe der reinen Soziologie, 2. Aufl., Berlin.

Toulmin, S. (1972), Human Understanding. The Collective Use and Evolution of Concepts, Princeton N.J..

Tsjechow, A.P. (1891), Het Duel, Amsterdam 1965.

Tully, J. (ed.) (1988), Meaning \& Context. Quentin Skinner and his Critics, Cambridge/Oxford.

Turner, F.J. (1893), The Significance of the Frontier in American History, in: Annual Report of the American Historical Association for 1893.

Turner, S.P. (1986), The Search for a Methodology of Social Science. Durkheim, Weber, and the Nineteenth-Century Problem of Cause; Probability; and Acrion, Dordrecht.

Turner, S.P. en R.A. Factor (1984), Max Weber and the dispute over reason and value, Londen.

Turner, S.P., J.H. Turner (1990), The Impossible Science: an Institutional Analysis of American Sociology, London.

Üner, E. (1981), Jugendbewegung und Soziologie. Wissenschaftssoziologische Skizzen zu Hans Freyers Werk und Wissenschaftsgemeinschaft bis 1933, in: Lepsius (1981): 131-159.

Veraguth, H.P. (1976), Erwachsenenbildung zwischen Religion und Politik, Stuttgart.

Verhandlungen der Generalversammlung in Mannheim (1905), Schriften des Vereins fur Sozialpolitik, Bd. 116, Leipzig 1906.

Verhandlungen des Ersten Deutschen Soziologentages wom 19. bis 22. Oktober 1910 in Frankfurt (1911), Tübingen.

Verhandlungen des Zweiten Deutschen Soziologentages vom 20. bis 22. Oktober 1912 in Berlin (1913), Tübingen.

Verhandlungen des Dritten Deutschen Soziologentages am 24. und 25. September 1922 in Jena (1923), Tübingen. 
Vidich, AJ,, S.M. Lyman (1985), American Sociology: Worldly Rejections of Religion and their Directions, New Haven/London.

Vierkandt, A. (Hrsg.) (1931), Handwörterbuch der Soziologie, Stuttgart.

Vincent, G.E. (1897), The Sacial Mind and Education, Chicago.

Vries, G. de (1977), Sociale orde, Regels en de Sociologie. Een wetenschapsfilosofisch onderzoek naar theorievorming in de sociologie, Meppel.

Vries, G.H. de (1982), De ontwikkeling van wetenschappelijke kennis, sociologisch beschouwd, in: Kennis en Methode 6: 190-220.

Vries, G. de (1985), De ontwikkeling van wetenschap. Een inleiding in de wetenschapsfilosofie, Groningen.

Vries, G. de (1988), Sociologie en radicaal pragmatisme, in: Kennis en Methode 12: 12129.

Vries, G. de (1990), Feitelijk expansionisme, een restrictionistische visie: praktische wetenschappen en waardevrijheid, in: D. Pels, G. de Vries (red.), Feiten en Waarden. De constructie van een onderscheid. Themanummer Kennis en Methode 14: 44-59.

Vries, G. de, L. Boon (1986), Een intellectuele zeppelin en zijn bemanning; de ambivalentie van cognitieve stijlen en de sociale organisatie van de psychoanalytische beweging, in: L. Boon en G. de Vries (red.), Vormen en functies van sociale wetenschappen, Amsterdam.

Wachelder, J.C.M. (1992), Universiteit tussen vorming en opleiding. De modernisering van de Nederlandse universiteiten in de negentiende eeuw, Hilversum.

Wagner, P., B. Wittrock, R. Whitley (eds.) (1991), Discourses on Society. The Shaping of the Socal Science Disciplines, Dordrecht.

Walther, A. (1927), Soziologie und Sozialwissenschaften in Amerika und ihre Bedeutung für die Padagogik, Karlsruhe.

Ward, L.F. (1883), Dynamic Sociology, 2nd edition, New York 1926.

Warner, J.H. (1991), Ideals of Science and Their Discontents in Late Nineteenth-Century American Medicine, in: Isis 82: 454-78.

Wassner, R. (1986), Andreas Walther und das Seminar für Soziologie in Hamburg zwischen 1926 und 1945, in: Papcke (1986): 386-420.

Wayland, F. (1837), Elements of Political Economy, Boston.

Weber, Marianne (1926), Max Weber. Ein Lebensbild, Tübingen $1984^{2}$.

Weber, M. (1904), Die 'Objectivitầt' sozialwissenschaftlicher und sozialpolitischer Erkenntnis, in: Gesammelte Aufsätze zur Wissenschaftslehre, Tübingen $1968^{3}$. 
Weber, M. (1910), Rede of den ersten Deutschen Soziologentage in Frankfurt, in: idem: Gesammelte Aufsatze zur Soziologie und Sozialpsychologie: 431-449.

Weber, M. (1914), Gutachten über die Werturteilsfrage, in: E. Baumgarten, Max Weber. Werk und Person, Tübingen 1964.

Weber, M. (1924), Debatrede auf der Tagung des Vereins für Sozialpolitik in Wien 1909, in: idem, Gesammelte Aufsätze zur Soziologie und Sozialpolitik, Tübingen.

Wegener, W. (1962), Die Quellen der Wissenschaftsauffassung Max Webers und die Problematik der Werturteilsfreiheit in der Sozialokonomie, Berlin.

Wehler, H-U. (1980), Das deutsche Kaiserreich 1871-1918, Göttingen.

Weinberg, J. (1972), Edward Alsworth Ross and the Sociology of Progressivism, Madison.

Wende, E. (1959), C.H. Becker, Mensch und Politiker, Stuttgart.

Weyer, J. (1984), Westdeutsche Soziologie 1945-1960. Deutsche Kontinultaten und nordamerikanischer Einfluss, Berlin.

Weyer, J. (1984), Westdeutsche Soziologie 1945-1960, Berlijn.

White, H. (1978), Tropics of Discourse Essays in Cultural Criticism, Baltimore/London.

White, A.D. (1890), Instruction in Social Science. Opening Adress at the General Meeting of 1890, in: Journal of Social Science 21: 1-20.

Wiebe, R. (1967), The search for order, 1877-1920, New York.

Wiese, L. von (Hrsg.) (1921), Soziologie des Volksbildungswesens, Múnchen-Leipzíg.

Wiese, L. von (1957), Erinnerungen, Koln-Opladen.

Wiese, L. von (1924a), Einsamkeit und Geselligkeit als Bedingungen der Mehrung des Wissens, in: M. Scheler (Hrsg.), Versuche zu einer Soziologie des Wissens, München/Leipzig.

Wiese, L. von (1924b), System der allgemeinen Soziologie als Lehre von den sozialen Prozessen und den sozialen Gebilden der Menschen (Beziehungslehre), Berlijn 1966.

Wiese, L. von, (1926), Geschichte und Hauptprobleme der Soziologie, Berlin.

Wiese, L. von (1934), Noch eimal: Das Werturteil in den Gesellschaftswissenschaften, in: Kölner Vienteljahrshefte für Soziologie 12: 390-400.

Wiese, L. von (1942), Das Problem einer Ethik auf soziologischer Grundlage, in: Archiv fur Rechts- und Sozialphilosophie 35: 34-54.

Wiggershaus, R. (1986), Die Frankfurter Schule. Geschichte, Theoretische Entwicklung, Politische Bedeutung, München/Wien. 
Wilde R. de (1984), "Die freischwebende Intelligenz" als ideologie en utopie. In: Kennis en Methode 8: 53-62.

Wilde, $R$. de (1987a), From Normal to Abnormal Discourse: A sociological interpretation of methodological controversies in Weimar-sociology, in: S. Bem, H. Rappart (eds.), Studies in the History of Psychology and the Sacial Sciences 4, Leiden.

Wilde, R. de (1987b), Tegen het perspectivisme, in: Kennis en Methode 11: 354-63.

Wilde, R. de (1989), De relativiteit van sociaal-wetenschappelijke kennis, in: M. Korthals (red.), Wetenschapsleer, Meppel/Amsterdam.

Wilde, R. de (1991), Rivaliteit en sociologie, in: F. Geraedts, L. de Jong (red.), Ergo Cogito III. Portret van een generatie, Groningen.

Wilde, R. de (1992), Tot Wetenschap beroepen. Max Weber en de morele dimensie van wetenschap, in: Theoretische Geschiedenis 19 (te verschijnen).

Wilde, R. de, G. de Vries (1987), De Constructie van Historische Continuïteit: Disciplinegeschiedenis en het verleden van de sociologie, in: J. Peschar en W. van Rossum (red.), Wetenschap en Technologie: Constructie en Dynamiek. De ontwikkeling van het wetenschapsonderzoek in Nederland, Deventer.

Williams, R. (1983), Keywords. A vocabulary of culture and society, rev. edition, London.

Wilson, D.J: (1990), Science, Community, and the Transformation of American Philosophy 1860-1930, Chicago/London.

Wittgenstein, L. (1958), Philosophische Untersuchungen, Frankfurt a. M. 1971

Wittrock, B. (1985), Dinosaurs or Dolphins? Rise and Resurgence of the ResearchOriented University, in: B. Wittrock, A. Elzinga, eds., The University Research System, Stockholm.

Wittrock, B., P. Wagner, H. Wollmann (1991), Social science and the modern state, in: P. Wagner et.al. (eds.), Social Sciences and Modem States, Cambridge.

Yeo, R. (1991), Reading Encyclopedias. Science and the Organization of Knowledge in British Dictionaries of Arts and Sciences, 1730-1850, in: Isis 82: 24-49.

Youmans, E.L. (1872), Social Science, in: The Popular Science Monthly, 1.

Zijderveld, A.C. (1974), De relativiteit van kennis en werkelijkheid. Inleiding tot de kennissociologie, Meppel. 


\section{CURRICULUM VITAE}

Reinder de Wilde werd op 20 september 1953 te Sneek geboren. In de periode 19661975 bezocht hij de 'MULO' te Norg en de 'HAVO' en de Pedagogische Academie te Groningen. Na een jaar als onderwijzer werkzaam te zijn geweest studeerde hij vanaf 1975 aan de Rijks Universiteit Groningen, waar hij na een kandidaatsexamen in de pedagogische en andragogische wetenschappen in 1984 cum laude het doctoraalexamen in de wijsbegeerte behaalde. Van 1984 tot 1988 was hij als onderzoeksmedewerker werkzaam bij de Nederlandse organisatie voor wetenschappelijk onderzoek. Sedert 1 mei 1988 is hij als universitair docent verbonden aan de vakgroep Wijsbegeerte van de Faculteit der Algemene Wetenschappen van de Rijksuniversiteit Limburg. 